Joep Schyns

SUSTAINABLE AND EFFICIENT ALLOCATION OF

LIMITED BLUE AND GREEN WATER RESOURCES i

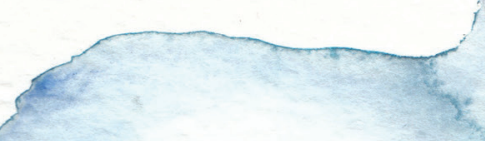

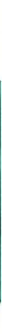

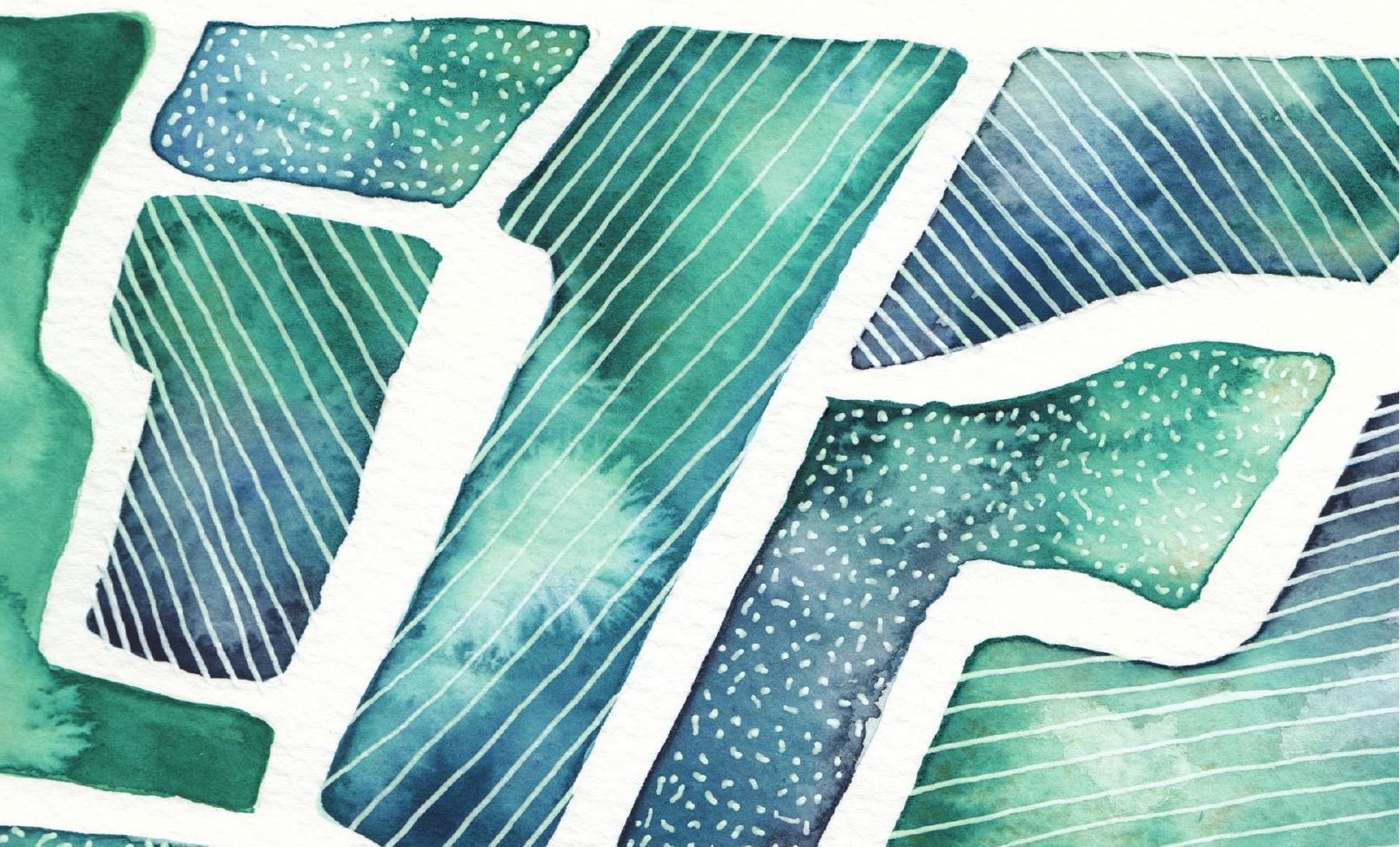





\section{SUSTAINABLE AND EFFICIENT ALLOCATION OF LIMITED \\ BLUE AND GREEN WATER RESOURCES}




\section{Graduation committee}

Prof. dr. G.P.M.R. Dewulf

Prof. dr. ir. A.Y. Hoekstra

Dr. ir. M.J. Booij

Prof. dr. D. Gerten

Prof. dr. ir. H.H.G. Savenije

Prof. dr. F. Ludwig

Prof. dr. J.T.A. Bressers

Prof. dr. J.C.J. Kwadijk
University of Twente, chairman, secretary

University of Twente, supervisor

University of Twente, co-supervisor

Humboldt-Universität Berlin

Delft University of Technology

Wageningen University

University of Twente

University of Twente 


\title{
SUSTAINABLE AND EFFICIENT \\ ALLOCATION OF LIMITED \\ BLUE AND GREEN WATER RESOURCES
}

\section{DISSERTATION}

\author{
to obtain \\ the degree of doctor at the University of Twente, \\ on the authority of the rector magnificus, \\ prof. dr. T.T.M. Palstra,
}

on the account of the decision of the graduation committee,

to be publicly defended

on Thursday 15 March 2018 at 14:45

by

Joseph Franciscus Schyns

born on 6 October 1989

in Doetinchem, the Netherlands 
This dissertation has been approved by:

Prof. dr. ir. A.Y. Hoekstra

supervisor

Dr. ir. M.J. Booij

co-supervisor

This research was conducted under the auspices of the Graduate School for SocioEconomic and Natural Sciences of the Environment (SENSE).

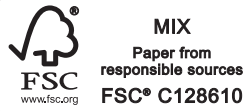

Copyright (C) Joep F. Schyns 2018. All rights reserved.

Cover artwork and design by (C) Nicole Schyns 2018.

Printed by Ipskamp Printing, Enschede.

ISBN: 978-90-365-4503-7

DOI: 10.3990/1.9789036545037 


\section{Table of Contents}

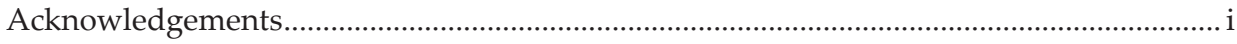

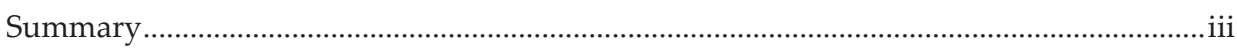

Samenvatting .................................................................................................................... vii

1. Introduction

2. The Added Value of Water Footprint Assessment for National Water Policy: A Case

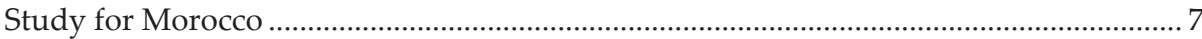

3. Mitigating the Risk of Extreme Water Scarcity and Dependency: The Case of Jordan. 33

4. Review and Classification of Indicators of Green Water Availability and Scarcity ...... 63

5. The Water Footprint of Wood for Lumber, Pulp, Paper, Fuel and Firewood ................. 89

6. Limits to the World's Green Water Resources for Food, Feed, Fibre, Timber and Bio-

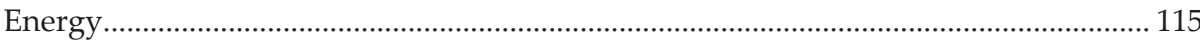

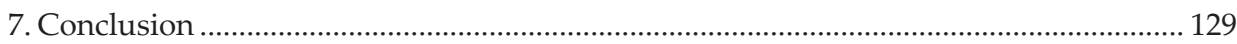

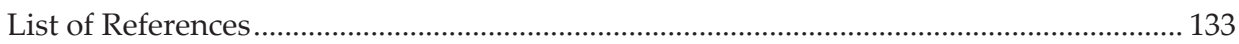

Appendix A: An Appendix to Chapter 2 ………….......................................................... 157

Appendix B: An Appendix to Chapter 4............................................................................. 159

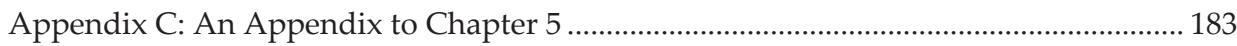

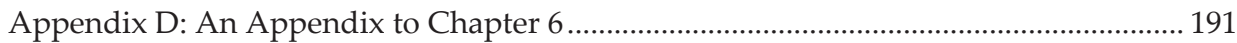

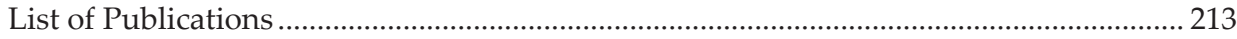

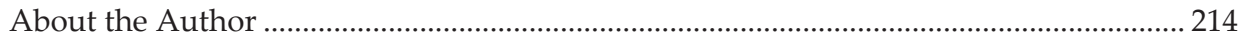





\section{Acknowledgements}

I am a happy and grateful person, privileged to be surrounded and supported by family, friends, and colleagues, whom I love, appreciate and admire in so many ways.

My supervisors Arjen and Martijn have been very approachable and involved. Arjen, after having supervised me as MSc student, you believed in my abilities, you stuck your neck out to enable this $\mathrm{PhD}$ project, and you gave me a great amount of freedom in determining the topic and content of it. You have given me many opportunities for personal development besides core research, such as giving guest lectures and participating in expert meetings. I admire your supervision style; you know which questions to ask to keep me on my toes and your clear vision has been supportive. I am deeply grateful for all you have done for me. Martijn, your sharp eye for detail and your knowledge of good scientific, mathematical, and communication practices improved this dissertation in numerous ways. You always took the time to provide me with elaborate feedback on my work, even at short notice. I admire your dedication to the guidance and education of students and I appreciate your sincerity. Our talks about experiences with publishing and presenting have been both amusing and informative. Thank you so much for all that.

I have many colleagues to thank. Thanks Rick for all the fun we've had as office mates and the blood, sweat and tears put in our joint modelling efforts. You have been the best conversation partner about the joys and struggles of PhD life, both having started our PhD's around the same time under similar circumstances. Also thanks to Hatem, Charlotte, Mireia, Ying and Angels for the good times we've had as office mates. Thanks Hatem for the shared experience of the EGU conference and the city of Vienna. Thanks Joke for being such a great support and for the fun we've had exchanging stories, pictures, and videos of your grandsons and my son. I further thank all other colleagues of the Water Engineering and Management groups and the Water Footprint Network who always make coming to work enjoyable. Thanks for your input during meetings and informal talks and thanks for the entertaining shared experiences such as dinners, department outings, and weekly soccer matches.

On a more technical note, I thank Deltares, the Water Footprint Network, and the Institute for Innovation and Governance Studies for their financial support and the open-source community behind PostgreSQL, Python, QGIS, and Stack Overflow for providing great software and support.

Life outside the office environment has been a joy with many milestones in the past four years. Thanks to all my friends and family for this. In particular I thank my friends Viktor, Roeland, Stijn, Nedim, and Jasper and the sports mates of the Stretchers. I can't find the words to express my gratitude towards my close family. Thanks Nicole for being the love of my life and a superb mother and wife. Thanks Adam for being the amazing little boy that you are. You two are the best part of my life and I look forward to 
every moment with you. Thanks Baco for the refreshing walks and your uplifting enthusiasm. Thanks to my parents and sisters, and my parents-in-law, brother-in-law, and sister-in-law for supporting us in so many ways and surrounding us so lovingly.

Joep Schyns

"If I have seen further, it is by standing upon the shoulders of giants." "Als ik verder zag, kwam dat omdat ik op de schouders van reuzen stond." Isaac Newton 


\section{Summary}

Freshwater stems from precipitation, which is limited in time and space. Precipitation over land differentiates into a blue water flow (runoff via groundwater and surface water) and a green water flow (evaporation). Both flows are partially allocated to serve the economy, resulting in blue and green water footprints (WF). There are maximum sustainable levels to the blue and green WF, since part of the flows need to be reserved to meet environmental flow requirements and conserve terrestrial biodiversity. Water scarcity, the degree to which the actual approaches the maximum sustainable WF, is becoming increasingly important due to increasing water consumption but limited water availability. The goal of this thesis is to broaden the discourse on freshwater scarcity in two respects. First, by assessing how Water Footprint Assessment (WFA) for a country can contribute to more sustainable and efficient allocation of blue water resources. Second, by assessing the allocation of the world's green water resources with respect to maximum sustainable levels. The first sub goal is approached by two case studies for blue water-scarce and water-dependent countries. Three subsequent studies work towards the second sub goal: a review of green water scarcity indicators; a global assessment of the WF of wood production; and a first assessment of green water scarcity.

The Added Value of Water Footprint Assessment for National Water Policy: A Case Study for Morocco. The aim of this study is to demonstrate the added value of detailed analysis of the human WF within a country and thorough assessment of the virtual water flows leaving and entering a country (the water needed to produce traded commodities) for formulating national water policy. A WFA is carried out for Morocco, mapping the WF of different activities per river basin per month, distinguishing between surface- and groundwater. Green, blue and grey WF (the grey WF represents the volume of water required to assimilate pollutants) estimates and virtual water flows are mainly derived from a previous grid-based $(5 \times 5$ arc minute) global study for the period 19962005. These estimates are placed in the context of monthly natural runoff and waste assimilation capacity per river basin derived from Moroccan data sources. The study finds that: (i) evaporation from storage reservoirs is the second largest form of blue water consumption in Morocco, after irrigated crop production; (ii) Morocco's water and land resources are mainly used to produce relatively low-value (in US\$/ $\mathrm{m}^{3}$ and US\$/ha) crops such as cereals, olives and almonds; (iii) most of the virtual water export from Morocco relates to the export of products with a relatively low economic water productivity (in US\$ $/ \mathrm{m}^{3}$ ); (iv) blue water scarcity on a monthly scale is severe in all river basins and pressure on groundwater resources by abstractions and nitrate pollution is 
considerable in most basins and; (v) the estimated potential water savings by partial relocation of crops to basins where they consume less water and by reducing WFs of crops down to benchmark levels are significant compared to demand reducing and supply increasing measures considered in Morocco's national water strategy.

Mitigating the Risk of Extreme Water Scarcity and Dependency: The Case of Jordan. Jordan faces great internal water scarcity and pollution, conflict over transboundary waters, and strong dependency on external water resources through trade. This study analyses these issues and subsequently reviews options to reduce the risk of extreme water scarcity and dependency. It is found that: (i) even while taking into account the return flows, blue water scarcity in Jordan is severe; (ii) groundwater consumption is nearly double the groundwater availability; (iii) water pollution aggravates blue water scarcity and (iv) while Jordan's dependence on transboundary resources is already large (34\%), its dependency on external water resources through trade is much larger (86\%). The review of response options yields 10 ingredients for a strategy for Jordan to mitigate the risks of extreme water scarcity and dependency. With respect to these ingredients, Jordan's current water policy requires a strong redirection towards water demand management. More attention should be paid to reducing water demand by changing the consumption pattern of Jordanian consumers and planned desalination projects require careful consideration regarding the sustainability of their energy supply. Sustainable mitigation of the inevitable large external water dependency involves importing waterintensive products and commodities from a diverse number of countries that are under a significantly lower degree of water scarcity than Jordan.

Review and Classification of Indicators of Green Water Availability and Scarcity. This study reviews and classifies around 80 indicators of green water availability and scarcity, and discusses the way forward to develop operational green water scarcity indicators that can broaden the scope of water scarcity assessments, which previously focused on blue water. It is found that the number of green water availability indicators by far outnumbers the existing green water scarcity indicators. A suitable - yet theoretical - green water scarcity indicator, which measures the degree to which the actual approaches the maximum sustainable green WF in a geographic area, faces two main operational challenges. First, the quantification of the green WF of wood production, considering that forest evaporation needs to be separated into a green and a blue part (because trees can directly take up groundwater through capillary rise) and that only part of the forest evaporation can be attributed to wood production in seminatural production forests. Second, a spatially-explicit assessment of green water 
availability, considering land suitability and the need to conserve additional lands for nature with respect to the current protected area network.

The Water Footprint of Wood for Lumber, Pulp, Paper, Fuel and Firewood. This study tackles the first operational challenge to measuring green water scarcity, previously identified. For the period 1961-2010, forest evaporation is estimated at a high spatial resolution and separated into green and blue components. Subsequently, total water consumption is attributed to various forest products, including ecosystem services. It is found that global water consumption for roundwood production increased by $25 \%$ over 50 years to $961 \times 10^{9} \mathrm{~m}^{3} / \mathrm{y}$ ( $96 \%$ green; $4 \%$ blue) in $2001-2010$. The WF per $\mathrm{m}^{3}$ of wood is significantly smaller in (sub)tropical forests compared to temperate/boreal forests, because (sub)tropical forests host relatively more value next to wood production in the form of other ecosystem services. In terms of economic water productivity and energy yield from bio-ethanol per unit of water, roundwood is rather comparable with major food, feed and energy crops. Recycling of wood products could effectively reduce the WF of the forestry sector, thereby leaving more water available for the generation of other ecosystem services. Intensification of wood production can only reduce the WF per unit of wood if the additional wood value per ha outweighs the loss of value of other ecosystem services, which is often not the case in (sub)tropical forests. The results of this study contribute to a more complete picture of the human appropriation of water, thus feeding the debate on water for food or feed versus energy and wood.

\section{Limits to the World's Green Water Resources for Food, Feed, Fibre, Timber and Bio-}

Energy. This study quantifies the allocation of the world's green water resources - the main source of water to produce food, feed, fibre, timber and bio-energy - and compares green WFs to regional maximum sustainable levels of green water availability, thereby tackling the second challenge to measuring green water scarcity, previously identified. Actual and maximum sustainable green WFs of crop production, livestock grazing, wood production and urban areas are estimated at a $5 \times 5$ arc minute grid cell spatial resolution, using a sophisticated allocation procedure that includes accounting for ecosystem services provided by forests and pastures. The study shows how the world's limited green water resources are allocated to different purposes and where we approach or overshoot maximum sustainable levels. It is found that green water is scarcer than blue water in 91 out of 163 countries, and that humanity is closer to the planetary boundary for green water (56\% appropriation) than for blue water (27-54\% appropriation). Human's green WF is close to or beyond the maximum sustainable level in Europe, Central America, the Middle East and South Asia. Globally, 18\% of the green 
WF is in areas to be reserved for nature. For a sustainable future, overshoot should be prevented and the green water resources below the maximum sustainable level should be used as productive as possible. This requires protection of lands, contraction of activities in areas with high conservation value and efficient production systems with increased water and land productivities through management of the full range of ecosystem services along the lines of sustainable intensification.

Conclusion. Dealing with freshwater scarcity requires sustainable and efficient allocation of blue and green water resources. This research has shown that national policies for sustainable and efficient use of blue water resources can be enriched by WFA. First, WFA feeds discussion on whether water is efficiently allocated, by showing the WF of end-purposes and the associated economic value. Second, WFA can provide enriching insights in pressures on blue water resources, by assessing the ratio of the actual to the maximum sustainable blue WF in a river basin at a monthly resolution and by quantifying the role of water pollution through assessment of the grey WF. Third, WFA reveals options to reduce water demand by changing production and consumption patterns, which can lead to significant savings compared to traditional measures considered in water management. Fourth, WFA emphasizes the risks of being dependent on water resources outside the country's borders when virtual water imports are placed in the context of water scarcity in the exporting nations. Furthermore, this research has shown that, to date, green water scarcity did not receive the attention it deserves. By quantifying the limits to green water availability, the main source of water to produce food, feed, fibre, timber and bio-energy, this research emphasizes the critical role green water has to play in the discourse on freshwater scarcity. 


\section{Samenvatting}

Zoetwater is afkomstig van neerslag en die neerslag is beperkt in de tijd en in de ruimte. Neerslag boven land kan worden onderverdeeld in blauw water (afvoer via grondwater en oppervlaktewater) en groen water (verdamping). Beide stromen worden deels toebedeeld aan economische activiteiten, met blauwe en groene watervoetafdrukken (WV) tot gevolg. De blauwe en groene watervoetafdruk kennen een maximaal duurzaam niveau, want een deel van de blauwe en groene waterstroom moet gereserveerd worden voor ecosystemen in de rivier en op het land. Waterschaarste - de mate waarin de daadwerkelijke watervoetafdruk het maximaal duurzame niveau benadert - wordt steeds belangrijker, omdat de watervraag toeneemt terwijl de beschikbaarheid van water beperkt is. Het doel van deze dissertatie is om het waterschaarstedebat op twee manieren te verbreden. Ten eerste, door te kijken hoe een watervoetafdrukanalyse (WVA) voor een land kan bijdragen aan een meer duurzame en efficiënte allocatie van blauw water. Ten tweede, door in te schatten hoe het groene water op aarde is toebedeeld aan verschillende doeleinden en hoe dit zich verhoudt tot een maximaal duurzaam niveau van de groene WV. Het eerste subdoel is benaderd door middel van twee case studies voor landen die blauwe waterschaarste kennen en die (indirect) sterk afhankelijk zijn van water in het buitenland. Drie achtereenvolgende studies werken naar het tweede subdoel toe: een evaluatie van indicatoren voor groene waterschaarste; een schatting van de WV van houtproductie wereldwijd; en een eerste kwantificatie van groene waterschaarste.

De Toegevoegde Waarde van Watervoetafdrukanalyse voor Nationaal Waterbeleid: Een Case Studie voor Marokko. Het doel van deze studie is om aan te tonen wat de toegevoegde waarde is van een gedetailleerde analyse van de WV in een land en een diepgaande evaluatie van de in- en uitgaande virtuele waterstromen van dat land (het water dat nodig is voor de productie van handelswaar) voor het formuleren van nationaal waterbeleid. Er is een WVA uitgevoerd voor Marokko waarbij - per stroomgebied per maand - de WV van verschillende activiteiten in kaart is gebracht en waarbij onderscheid is gemaakt tussen oppervlaktewater en grondwater. De schattingen van de groene, blauwe en grijze WV (de grijze WV is een maat voor de hoeveelheid water die nodig is om vervuilende stoffen op te nemen of te verdunnen) en die van de virtuele waterstromen, zijn voornamelijk afgeleid van een voorgaande globale studie op rasterniveau ( 5 x 5 boogminuten) voor de periode 1996-2005. Deze schattingen zijn in de context geplaatst van de natuurlijke rivierafvoer (per maand) en de capaciteit van een rivier om vervuilende stoffen op te nemen; beiden per stroomgebied en afgeleid van 
Marokkaanse databronnen. De uitkomsten van deze studie zijn dat: (i) verdamping van stuwmeren de op één na grootste vorm van blauw watergebruik is, na geïrrigeerde landbouw; (ii) het water en land in Marokko voornamelijk wordt ingezet om relatief laagwaardige (in US\$/ $\mathrm{m}^{3}$ en US\$/ha) gewassen te produceren, zoals granen, olijven en amandelen; (iii) het leeuwendeel van het water dat Marokko virtueel verlaat gerelateerd is aan de export van producten met een relatief lage economische waterproductiviteit (in $\mathrm{US} \$ / \mathrm{m}^{3}$ ); (iv) ernstige blauwe waterschaarste optreedt in alle stroomgebieden op maandelijkse schaal en dat de meeste stroomgebieden kampen met een aanzienlijke druk op grondwater door onttrekkingen en nitraatvervuiling; (v) er potentieel veel water bespaard zou kunnen worden - zeker in vergelijking met de huidige plannen in de Marokkaanse waterstrategie om de watervraag te verminderen en de beschikbaarheid te vergroten - door gewassen deels te verplaatsen naar stroomgebieden waar ze minder water verbruiken en door de WV van gewassen te reduceren naar benchmarkniveaus.

\section{Beperking van het Risico van Extreme Waterschaarste en Waterafhankelijkheid: Het} Voorbeeld van Jordanië. Jordanië heeft te maken met grote interne waterschaarste en watervervuiling, conflicten over grensoverschrijdende wateren, en een sterke afhankelijkheid van externe waterhulpbronnen door de handel. In deze studie worden deze kwesties onder de loep genomen om vervolgens tot een evaluatie te komen van maatregelen om het risico van extreme waterschaarste en -afhankelijkheid te reduceren. De bevindingen zijn dat: (i) blauwe waterschaarste in Jordanië ernstig is, zelfs als de terugstroom van ongebruikt water wordt meegenomen; (ii) de consumptie van grondwater bijna twee keer zo groot is als de beschikbaarheid ervan; (iii) watervervuiling blauwe waterschaarste versterkt en (iv) terwijl Jordanië al een grote afhankelijkheid kent van grensoverschrijdende wateren (34\%), het land nog veel sterker afhankelijk is van externe waterhulpbronnen door handel (86\%). De evaluatie van maatregelen heeft 10 ingrediënten opgeleverd voor een waterstrategie voor Jordanië die het risico van extreme waterschaarste en -afhankelijkheid vermindert. Met betrekking tot deze ingrediënten dient het huidige waterbeleid van Jordanië sterk bijgestuurd te worden richting het managen van de watervraag. Daarbij zou meer aandacht geschonken moeten worden aan het reduceren van de watervraag door aanpassingen in het consumptiepatroon van de Jordaanse consumenten. Verder is het zaak om zorgvuldig na te denken over een duurzame energievoorziening voor de geplande ontziltingsprojecten. Het op een duurzame manier beperken van de onontkoombaar grote waterafhankelijkheid betekent dat water-intensieve producten en handelswaren 
vanuit een divers aantal landen worden geïmporteerd, en wel landen die een significant lager niveau van waterschaarste ervaren dan Jordanië zelf.

\section{Evaluatie en Classificatie van Indicatoren voor Groene Waterbeschikbaarheid en} Waterschaarste. Deze studie omvat een evaluatie en classificatie van circa 80 indicatoren voor groene waterbeschikbaarheid en -schaarste, en geeft aan welke weg er te gaan is om operationele groene waterschaarste-indicatoren te ontwikkelen die kunnen bijdragen aan een verbreding van waterschaarstestudies die nu vooral op blauw water gericht zijn. Er is vastgesteld dat er veel meer indicatoren zijn voor de beschikbaarheid van groen water, dan voor groene waterschaarste. Een geschikte groene waterschaarste-indicator meet de mate waarin de daadwerkelijke groene $\mathrm{WV}$ in een geografisch gebied de maximaal duurzame groene $\mathrm{WV}$ in dat gebied benadert. Een dergelijke indicator is op dit moment nog niet operationeel, hoofdzakelijk vanwege de volgende twee uitdagingen. Ten eerste, het kwantificeren van de groene WV van houtproductie, gegeven dat er onderscheid gemaakt dient te worden tussen de groene en de blauwe component van de verdamping van een bos (want bomen kunnen met hun wortels het grondwater bereiken) en gegeven dat slechts een deel van die verdamping toegeschreven kan worden aan houtproductie in semi-natuurlijke bossen die ook andere doeleinden dienen. Ten tweede, een ruimtelijk expliciete inschatting van groene waterbeschikbaarheid, gezien variabele landgeschiktheid en de noodzaak om het huidige netwerk aan beschermde gebieden uit te breiden.

\section{De Watervoetafdruk van Hout voor Bouwhout, Pulp, Papier, Brandstof en Brandhout.}

Deze studie richt zich op de eerste, zojuist geïdentificeerde, uitdaging voor het meten van groene waterschaarste. Bosverdamping is geschat op een hoge ruimtelijke resolutie voor de periode 1961-2010 en gescheiden in groene en blauwe componenten. Vervolgens is de totale waterconsumptie toegekend aan verschillende bosproducten, inclusief ecosysteemdiensten. De bevinding is dat de wereldwijde waterconsumptie voor houtproductie met $25 \%$ is toegenomen in 50 jaar tijd naar gemiddeld $961 \times 10^{9} \mathrm{~m}^{3} / \mathrm{y}(96 \%$ groen; 4\% blauw) gedurende 2001-2010. De WV per $\mathrm{m}^{3}$ hout is significant kleiner in (sub)tropische bossen vergeleken met bossen in de gematigde en boreale zones, omdat (sub)tropische bossen relatief meer waarde herbergen naast houtproductie in de vorm van andere ecosysteemdiensten. In termen van economische waterproductiviteit en de energieopbrengst van bio-ethanol per eenheid water, is hout tamelijk vergelijkbaar met grote voedsel-, voeder- en energiegewassen. Het hergebruiken van houtproducten is een effectieve manier om de WV van de bosbouwsector te reduceren, waarbij meer water beschikbaar blijft voor het genereren van andere ecosysteemdiensten. Intensivering van 
houtproductie kan alleen tot een kleinere WV per eenheid hout leiden als de additioneel verkregen houtwaarde per ha opweegt tegen het verlies aan waarde van andere ecosysteemdiensten; wat vaak niet het geval is in (sub)tropische bossen. Het resultaat van deze studie draagt bij aan een completer beeld van de inzet van water ten gunste van de mens en voedt daarmee het debat over water voor voedsel en voeder versus energie en hout.

\section{Grenzen aan de Mondiale Groene Waterhulpbronnen voor Voedsel, Voeder, Vezels,} Hout en Bio-energie. Deze studie omvat een kwantificatie van de toedeling van de groene waterhulpbronnen op aarde - de hoofdbron van water voor de productie van voedsel, voeder, vezels, hout en bio-energie - en een vergelijking van de groene WV met regionaal maximaal duurzame niveaus van groene waterbeschikbaarheid. Zodoende wordt de tweede eerder geïdentificeerde uitdaging voor het meten van groene waterschaarste aangepakt. Daadwerkelijke en maximaal duurzame groene WV-en van gewasproductie, begrazing door vee, houtproductie en stedelijk gebied zijn ingeschat op het niveau van rastercellen van $5 \times 5$ boogminuten. Daarbij wordt een geavanceerde toekenningsprocedure gehanteerd die rekening houdt met de ecosysteemdiensten die bossen en graslanden leveren. De studie laat zien hoe de beperkte hoeveelheid groen water op de wereld is toegekend aan verschillende doeleinden en waar we maximaal duurzame niveaus benaderen of overschrijden. Het blijkt dat groen water schaarser is dan blauw water in 91 van 163 landen en dat de mensheid dichter bij de mondiale grens van groen water (56\% in gebruik) dan voor blauw water $(27-54 \%$ in gebruik) is. De groene WV van de mens is nabij of zelf voorbij het maximaal duurzame niveau in Europa, Centraal Amerika, het Midden Oosten en Zuid-Azië. Wereldwijd is 18\% van de groene WV in gebieden die voor de natuur gereserveerd zouden moeten zijn. Voor een duurzame toekomst moet overschrijding van het maximaal duurzame niveau vermeden worden en dient het groene water beneden dat niveau zo productief mogelijk ingezet te worden. Dit vraagt om de bescherming van land, het beperken van activiteiten in gebieden met een hoge biodiversiteitswaarde en efficiëntie productiesystemen waarin hogere water- en landproductiviteit wordt nagestreefd door het managen van het gehele palet aan ecosysteemdiensten volgens de principes van duurzame intensivering.

Conclusie. Omgaan met waterschaarste vraagt om een duurzame en efficiënte allocatie van blauw en groen water. Dit onderzoek laat zien dat nationaal beleid om duurzaam en efficiënt gebruik van blauw water te bewerkstelligen verrijkt kan worden met behulp van WVA. Ten eerste voedt WVA de discussie over een efficiënte waterallocatie door inzicht te geven in de WV van doeleinden en hun economische waarde. Ten tweede kan 
WVA extra inzichten verschaffen in de druk op blauw water. Dit, door een analyse van de blauwe WV ten opzichte van de maximaal duurzame blauwe WV per stroomgebied per maand en door het kwantificeren van de rol van watervervuiling door middel van de grijze WV. Ten derde komen uit WVA maatregelen naar voren ter reductie van de watervraag door aanpassingen in productie- en consumptiepatronen die tot significante waterbesparingen kunnen leiden in vergelijking met conventionele water management maatregelen. Ten vierde benadrukt WVA het risico van de afhankelijkheid van water buiten de landsgrenzen wanneer de virtuele waterimport in de context wordt geplaatst van de aanwezige waterschaarste in de exporterende landen. Verder heeft dit onderzoek uitgewezen dat, tot de dag van vandaag, groene waterschaarste niet de verdiende aandacht heeft ontvangen. Door het kwantificeren van de grenzen aan de beschikbaarheid van groen water, de hoofdbron van water voor het produceren van voedsel, voeder, vezels, hout en bio-energie, benadrukt dit onderzoek de kritieke rol van groen water in het debat over zoetwaterschaarste. 



\section{Introduction}

\subsection{Increasing Water Consumption but Limited Water Availability}

Water scarcity is becoming increasingly important. As the world population grows, there is an increasing need to produce food, feed, fibre, timber, energy and other goods and services (Hejazi et al., 2014; WWAP, 2015). The food and energy sectors are increasingly water-intensive, due to more consumption of animal products (Molden, 2007) and policies towards an increased share of bio-energy in the global energy mix (Mekonnen et al., 2016). Water scarcity is aggravated by a changing climate with increased variability and more extremes (IPCC, 2013; WWAP, 2014).

Fresh water stems from precipitation. Precipitation over land differentiates into blue and green water (Falkenmark, 2000) (see Figure 1-1). The water that recharges groundwater and runs through rivers to the ocean, is called blue water. The water that does not end up in groundwater or surface water, but directly evaporates ${ }^{1}$ back to the atmosphere from the land surface, is called green water. Precipitation is limited in time and space, and so are the resulting blue and green water flows (Hoekstra, 2013). Both flows are allocated to serve human activities, explicitly through blue water withdrawals and implicitly through the allocation of land with its associated green water flow. We use these flows to grow rain-fed (with green water only) and irrigated (through a combination of green and blue water) crops, sustain production forests (green water) and grazing pastures (green water), and apply it in households (blue water) and industries (blue water). These productive purposes have a water footprint, because water allocated to one purpose will no longer be available in the same area and time period for another purpose (Hoekstra et al., 2011; Hoekstra, 2017). There are maximum sustainable levels to the blue and green water footprints (Hoekstra \& Wiedmann, 2014) (Figure 1-1), since a minimum flow in rivers is required for aquatic biodiversity (Richter et al., 2012) and part of the land with its associated green water flow should be left to sustain terrestrial biodiversity (Pouzols et al., 2014) and other ecosystem services (Costanza et al., 2014; Costanza et al., 2017).

\footnotetext{
1 Throughout this thesis the term evaporation is used (instead of the often used term evapotranspiration) to refer to the entire vapour flux from land to atmosphere which includes soil evaporation, evaporation of intercepted water, transpiration and in some cases (e.g. wetlands or rice fields) open-water evaporation (Savenije, 2004).
} 


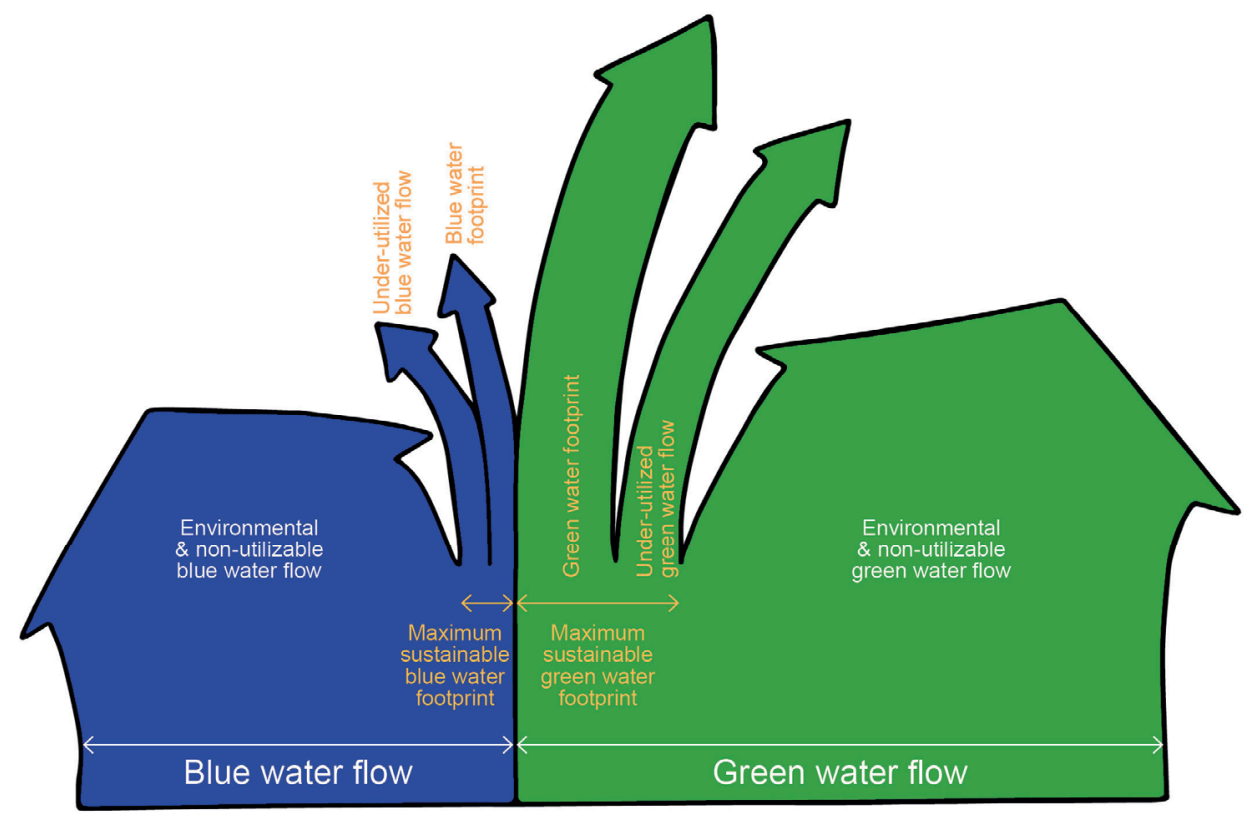

Figure 1-1. The partitioning of precipitation over land into blue and green water flows. Both flows further partition into environmental and non-utilizable (or non-accessible) flows, flows allocated to human activities (i.e. water footprint) and under-utilized flows below the maximum sustainable level.

\subsection{Blue and Green Water Scarcity}

The ratio of the actual to the maximum sustainable water footprint (Figure 1-1) shows the extent to which limited water resources have been allocated to human activities and is thus an indicator of the degree of water scarcity (Hoekstra et al., 2011). This water scarcity ratio can be expressed for both blue and green water, separately.

Blue water scarcity has been assessed at numerous spatial and temporal resolutions (Vanham et al., 2018). Most development has been in the temporal resolution. In the past, blue water scarcity assessments have been mostly done per year (Vörösmarty et al., 2000; Oki et al., 2001; Alcamo et al., 2003). Recent assessments per month (Wada et al., 2011; Hoekstra et al., 2012; Mekonnen \& Hoekstra, 2016) have revealed that these annual assessments resulted in an underestimation of blue water scarcity due to the failure to capture the intra-annual mismatch between water demand and availability.

People have been managing blue water scarcity for ages. Traditionally, management is focused on supplying water to the users, which resulted in the constructions of dams, inter-basin water transfers and irrigation networks. Since the nineties, there is more attention for water demand management (Savenije et al., 2014). In practice, this usually 
happens through campaigns - often combined with water pricing - that encourage households to use less water and train farmers in applying less irrigation. Two main aspects are, however, rarely considered in the development of national water policies to sustainably manage blue water scarcity. First, the end-purposes themselves to which water is allocated are rarely questioned (allocation efficiency). Second, the global dimension of water is generally not taken into account (Hoekstra, 2011). There is international trade in goods which have a water footprint (i.e. virtual water trade). This means that, on the one hand, countries allocate water to produce goods for export and, on the other hand, countries are dependent on water resources in other countries from which they import. Therefore, national water policies might be enriched by a Water Footprint Assessment (Hoekstra et al., 2011) that includes these two aspects.

In the 1990s, Falkenmark $(1995 ; 2000)$ pointed to the importance of green water, which is the main source of water for the production of biomass. The recognition of green next to blue water consumption increasingly gained acceptance in the past decades (Postel et al., 1996; Savenije, 2000; Rockström, 2001; Falkenmark \& Rockström, 2006; Rijsberman, 2006; Rost et al., 2008; Liu et al., 2009; Falkenmark \& Rockström, 2010; Hanasaki et al., 2010; Siebert \& Döll, 2010; Hoekstra \& Mekonnen, 2012). However, limits to green water consumption have not been quantified. The notion that there is a maximum sustainable green water footprint and that green water is thus a scarce resource is so far only theoretical (Hoekstra et al., 2011). A few attempts have been made to incorporate green water in the discourse on freshwater scarcity, using different definitions of green water scarcity from the one used in this research (see top of this section). Combined green-blue water scarcity assessments (Rockström et al., 2009; Gerten et al., 2011; Kummu et al., 2014) reflect green and blue water resource availability with respect to hypothetical green and blue water needs to sustain a standard diet. Falkenmark et al. (2007) and Falkenmark (2013a) define green water scarcity as an issue of limited green water accessibility in the root zone and the occurrence of unproductive evaporation losses from the field, which results in lower yields than potentially achievable by proper crop and soil management.

While green water is just entering the scientific debate on freshwater scarcity, limits to green water availability are not at all on the radar of policy makers. Low-carbon energy scenarios heavily rely on biomass and green water (Mekonnen et al., 2016), while the International Energy Agency in their World Energy Outlook still ignores green water (OECD/IEA, 2016). Therefore, an assessment of the degree to which green water consumption approaches maximum sustainable levels is highly due. 


\subsection{Goal and Approach of this Research}

The goal of this thesis is to broaden the discourse on freshwater scarcity in two respects. First, by assessing how Water Footprint Assessment for a country can contribute to more sustainable and efficient allocation of blue water resources. Second, by assessing the allocation of the world's green water resources with respect to maximum sustainable levels. This is captured in two main research questions:

1. How can national policies for sustainable and efficient use of blue water resources be enriched by Water Footprint Assessment?

2. How are the world's limited green water resources allocated to different purposes and where do we approach or overshoot maximum sustainable levels?

Question 1 is approached by means of two case studies for countries that face internal water scarcity and external water dependency: Morocco (Chapter 2) and Jordan (Chapter 3). For these countries, I have carried out a Water Footprint Assessment and assessed the added value with respect to existing national water policies and river basin plans. For Morocco, the focus is on internal blue water scarcity and allocation efficiency. For Jordan, more attention is paid to sustainable mitigation of the external water dependency through trade.

Question 2 is simple in nature, but requires several preceding questions to be answered. First, conceptual clarity is needed on the concept of green water scarcity. I have reviewed and classified indicators of green water availability and scarcity, thereby exposing the lack of green water scarcity indicators in Chapter 4. Second, to assess global green water scarcity we need to know the green water footprint $\left(W F_{g}\right)$ of humanity. We want to know $W F_{g}$ of humanity at the grid level to quantify actual versus maximum sustainable WFg's using a bottom-up approach, which is more accurate than lumping these variables to higher spatial aggregation levels before comparing them (see also Gerten et al. (2013)). However, in contrast to $W F_{g}$ of crops - which has been estimated at high spatial resolution by many (Liu et al., 2009; Mekonnen \& Hoekstra, 2011a; Siebert \& Döll, 2010; Rost et al., 2008; Hanasaki et al., 2010) - WFg of wood production has not been quantified before, and $W F_{g}$ of livestock grazing is not available at the grid level (Mekonnen \& Hoekstra, 2012b; De Fraiture et al., 2007). A complication is that forests and pastures provide several other ecosystem services besides wood and food production, respectively. How to properly account for this when estimating $W F_{g}$ of wood production and livestock grazing? In Chapter 5, I address this question while estimating the $W F_{\mathrm{g}}$ of wood production world-wide. In Chapter 6, I complete the picture 
of human's $W F_{\mathrm{g}}$ by estimating the grid-specific $W F_{\mathrm{g}}$ of livestock grazing and urban areas (that occupy land with its associated green water flow) and show how the world's limited green water resources are allocated to different purposes and where we approach or overshoot maximum sustainable levels.

\subsection{Structure of the Research}

The structure of this thesis is conceptually visualized in Figure 1-2. Overarching conclusions of this thesis and a future outlook are provided in Chapter 7.

\section{How can national policies for sustainable and efficient use of blue water resources be enriched by Water Footprint Assessment?}

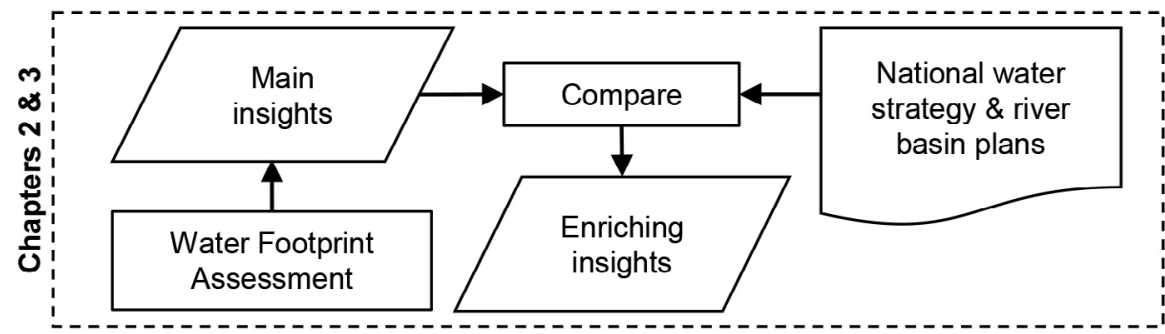

How are the world's limited green water resources allocated to different purposes and where do we approach or overshoot maximum sustainable levels?

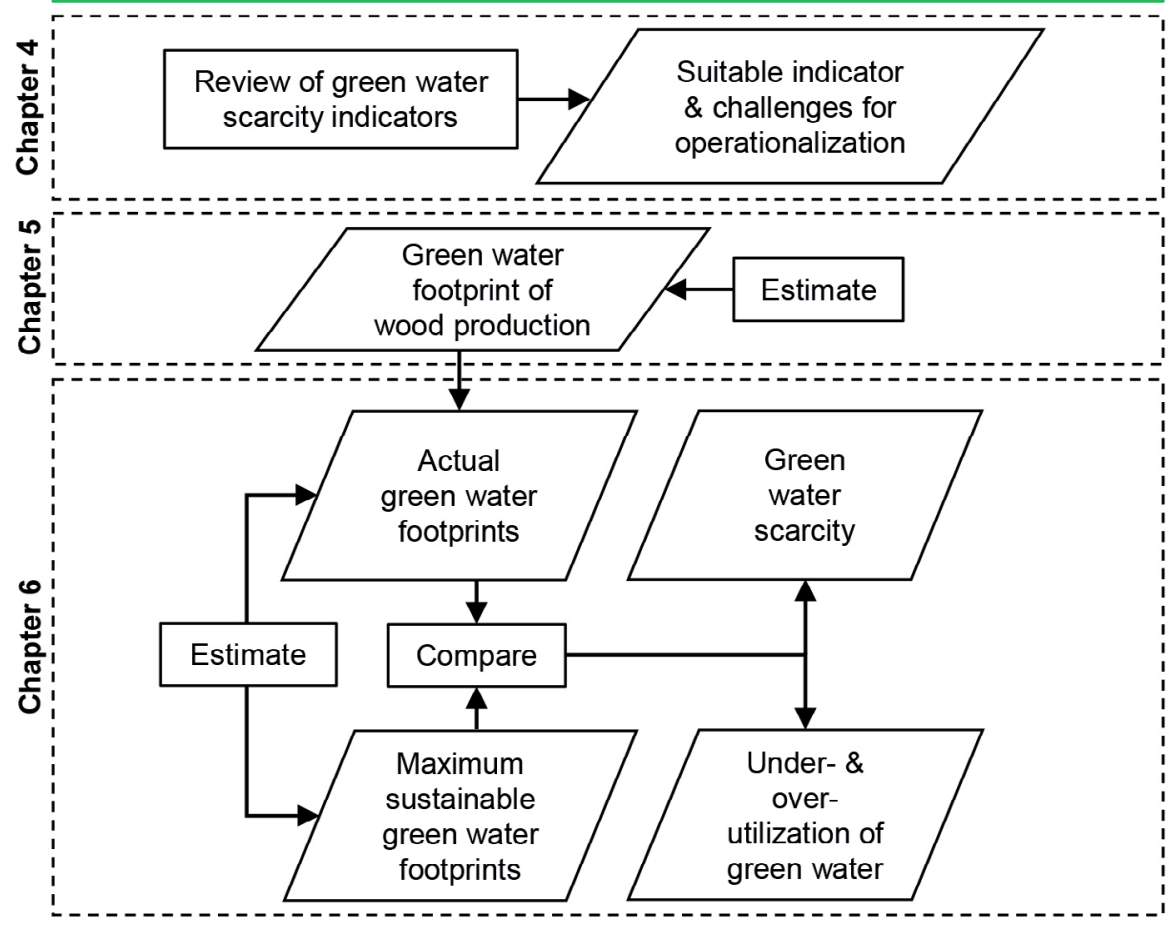

Figure 1-2. Conceptual diagram of the structure of this thesis. 


\title{
2. The Added Value of Water Footprint Assessment for National Water Policy: A Case Study for Morocco
}

\begin{abstract}
A Water Footprint Assessment is carried out for Morocco, mapping the water footprint of different activities at river basin and monthly scale, distinguishing between surfaceand groundwater. The paper aims to demonstrate the added value of detailed analysis of the human water footprint within a country and thorough assessment of the virtual water flows leaving and entering a country for formulating national water policy. Green, blue and grey water footprint estimates and virtual water flows are mainly derived from a previous grid-based ( $5 \times 5$ arc minute) global study for the period 1996-2005. These estimates are placed in the context of monthly natural runoff and waste assimilation capacity per river basin derived from Moroccan data sources. The study finds that: (i) evaporation from storage reservoirs is the second largest form of blue water consumption in Morocco, after irrigated crop production; (ii) Morocco's water and land resources are mainly used to produce relatively low-value (in US $\$ / \mathrm{m}^{3}$ and US\$/ha) crops such as cereals, olives and almonds; (iii) most of the virtual water export from Morocco relates to the export of products with a relatively low economic water productivity (in $\left.\mathrm{US} \$ / \mathrm{m}^{3}\right)$; (iv) blue water scarcity on a monthly scale is severe in all river basins and pressure on groundwater resources by abstractions and nitrate pollution is considerable in most basins and; (v) the estimated potential water savings by partial relocation of crops to basins where they consume less water and by reducing water footprints of crops down to benchmark levels are significant compared to demand reducing and supply increasing measures considered in Morocco's national water strategy.
\end{abstract}

\subsection{Introduction}

Morocco is a semi-arid country in the Mediterranean facing water scarcity and deteriorating water quality. The limited water resources constrain the activities in different sectors of the economy of the country. Agriculture is the largest water consumer and withdrawals for irrigation peak in the dry period of the year, which contributes to low surface runoff and desiccation of streams. Currently, 130 reservoirs are in operation to deal with this mismatch in water demand and natural water supply and to serve for generation of hydroelectricity and flood control (Ministry EMWE, 2011).

2 This chapter has been published as:

Schyns, J.F. \& Hoekstra, A.Y. (2014) The added value of water footprint assessment for national water policy: a case study for Morocco, PLoS ONE, 9(6): e99705. 
Groundwater resources also play an important role in the socio-economic development of the country, in particular by ensuring the water supply for rural communities (Ministry EMWE, 2012). However, a large part of the aquifers is being overexploited and suffer from deteriorating water quality by intrusion of salt water, caused by the overexploitation, and nitrates and pesticides that leach from croplands, caused by excessive use of fertilizers. Surface water downstream of some urban centres is also polluted, due to untreated wastewater discharges.

In 1995, the Moroccan Water Law (no. 10-95) came into force and introduced decentralized integrated water management and rationalisation of water use, including the user-pays and polluter-pays principles. It also dictates the development of national and river basin master plans (Official State Gazette, 1995), which are elaborated in accordance with the national water strategy. To cope with water scarcity and pollution, the national water strategy includes action plans to reduce demand, increase supply and preserve and protect water resources (Ministry EMWE, 2011). It also proposes legal and institutional reforms for proper implementation and enforcement of these actions. Demand management focuses on improving the efficiency of irrigation and urban supply networks and pricing of water to rationalise its use. Plans to increase supply include the construction of more dams and a large North-South inter-basin water transfer, protection of existing hydraulic infrastructure, desalinization of sea water and reuse of treated wastewater.

Although the national water strategy considers options to reduce water demand in addition to options to increase supply, it does not include the global dimension of water by considering international virtual water trade, nor does it consider whether water resources are efficiently allocated based on physical and economic water productivities of crops (the main water consumers). Analysis of the water footprint (WF) of activities in Morocco and the virtual water trade balance of the country therefore might reveal new insights to alleviate water scarcity.

The concept of WF was introduced by Hoekstra (2003); this subsequently led to the development of Water Footprint Assessment as a distinct field of research and application (Hoekstra \& Chapagain, 2008; Hoekstra et al., 2011). The WF is an indicator of freshwater use that looks not only at direct water use of a consumer or producer, but also at the indirect water use. As such, it provides a link between human consumption and human appropriation of freshwater systems. Water Footprint Assessment refers to a variety of methods to quantify and map the WF of specific processes, products, producers or consumers, to assess the environmental, social and economic sustainability 
of WFs at catchment or river basin level and to formulate and assess the effectiveness of strategies to reduce WFs in prioritized locations. The WF of a product is the volume of freshwater used to produce the product, measured over the full supply chain (Hoekstra et al., 2011). Three different components of a WF are distinguished: green, blue and grey. The green WF is the volume of rainwater evaporated or incorporated into the product. Blue water refers to the volume of surface- or groundwater evaporated, incorporated into the product or returned to another catchment or the sea. The grey WF relates to pollution and is defined as the volume of freshwater that is required to assimilate the load of pollutants given natural background concentrations and existing ambient water quality standards (Hoekstra et al., 2011). The total freshwater volume consumed or polluted within the territory of a nation as a result of activities within the different sectors of the economy is called the WF of national production. International trade of products creates 'virtual water flows' leaving and entering a country. The virtual-water export from a nation refers to the WF of the products exported. The virtual-water import into a nation refers to the WF of the imported products.

Several authors have assessed the WF and virtual water trade balance of nations and regions and state the relevance of the tool for well-informed water policy on the national and river basin level (Aldaya et al., 2010a; Aldaya et al., 2010b; Chahed et al., 2011; Hoekstra \& Mekonnen, 2012). In a case study for a Spanish region, Aldaya et al. (2010b) conclude that WF analyses can provide a transparent framework to identify potentially optimal alternatives for efficient water use at the catchment level and that this can be very useful to achieve an efficient allocation of water and economic resources in the region. Chahed et al. (2011) state that integration of all water resources at the national scale, including the green water used in rain-fed agriculture and as part of the foodstuffs trade balance, is essential in facing the great challenges of food security in arid countries.

The objective of this study is to explore the added value of analysing the WF of activities in Morocco and the virtual water flows from and to Morocco in formulating national water policy. The study includes an assessment of the WF of activities in Morocco (at the river basin level on a monthly scale) and the virtual water trade balance of the country and, based on this, response options are formulated to reduce the WF within Morocco, alleviate water scarcity and allocate water resources more efficiently. Results and conclusions from the Water Footprint Assessment are compared with the scope of analysis of, and action plans included in Morocco's national water strategy and river basin plans in order to address the added value of Water Footprint Assessment relative to these existing plans. 
The WF of Morocco has not been assessed previously on the river basin level on a monthly scale. Morocco has been included in a number of global studies, but these studies did not analyse the spatial and temporal variability of the WF within the country (Hoekstra \& Chapagain, 2007b; Hoekstra \& Chapagain, 2007a; Mekonnen \& Hoekstra, 2011b). Furthermore, this study is the first to include specific estimates of the evaporative losses from the irrigation supply network and from storage reservoirs as part of a comprehensive Water Footprint Assessment. Finally, it is new in providing quantitative estimates of the potential water savings by partial relocation of crop production to regions with lower water consumption per tonne of crop by means of an optimization and by reducing WFs of crops down to benchmark levels.

Several insights and response options emerged from the Water Footprint Assessment, which are currently not considered in the national water strategy of Morocco and the country's river basin plans. Therefore, Water Footprint Assessment is considered to have an added value for formulating national water policy in Morocco.

\subsection{Method and Data}

\subsubsection{Water Footprint of Morocco's Production}

This study follows the terminology and methodology developed by Hoekstra et al. (2011). The WF of Morocco's production is estimated at river basin level on a monthly scale for the activities included in Table 2-1. The river basins are chosen such that they coincide with the action zones of Morocco's river basin agencies (Figure 2-1A). Due to data limitations, the grey WF is analysed on an annual scale and the WFs of grazing and animal water supply are analysed at national and annual level. The study considers the average climate, production and trade conditions over the period 1996-2005. The WFs of agriculture, industry and households are obtained from Mekonnen and Hoekstra (2010b, 2011b), who estimated these parameters globally at a $5 \times 5$ arc minute spatial resolution. The annual blue WF estimates for industries and households by Mekonnen \& Hoekstra (2011b) are distributed throughout the year according to the monthly distribution of public water supply obtained from Ministry EMWE (unpublished data 2013). These distributions are available for the basins Loukkos, Sebou, Bouregreg and Oum Er Rbia. For the other basins an average of these distributions is taken. 
Table 2-1. Water footprint estimates included in this study.

\begin{tabular}{|llll|}
\hline Water footprint of & Components & Period & Source \\
\hline Crop production & Green, blue, & $1996-2005$ & Mekonnen \& Hoekstra (2010b) \\
grey & Green & $1996-2005$ & Mekonnen \& Hoekstra (2011b) \\
Animal water supply & Blue & $1996-2005$ & Mekonnen \& Hoekstra (2011b) \\
Industrial production & Blue, grey & $1996-2005$ & Mekonnen \& Hoekstra (2011b) \\
$\begin{array}{l}\text { Domestic water } \\
\text { supply }\end{array}$ & Blue, grey & $1996-2005$ & Mekonnen \& Hoekstra (2011b) \\
Storage reservoirs & Blue & - & \\
Irrigation water & Blue & $1996-2005$ & Own elaboration \\
supply network & & & \\
\hline
\end{tabular}
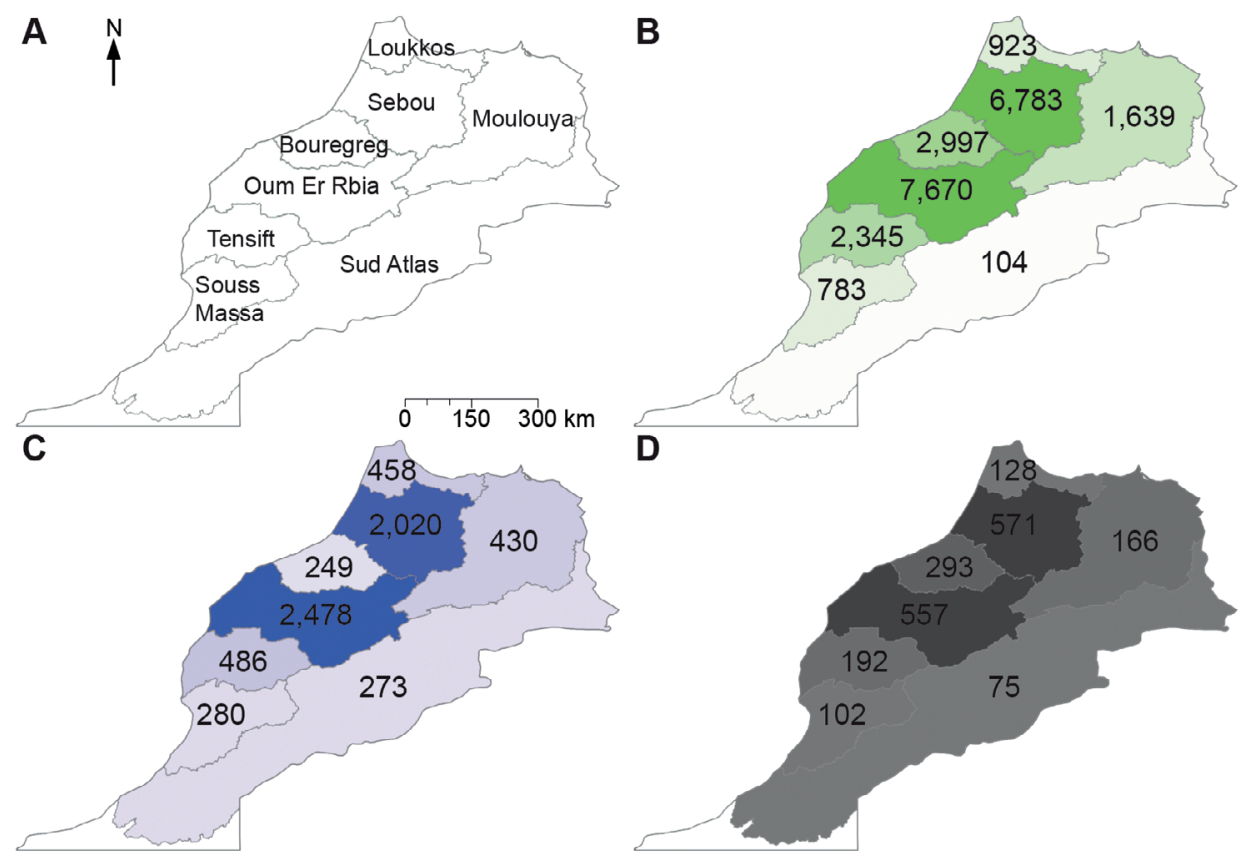

Figure 2-1. Water footprint of Morocco's production per river basin. Period: 1996-2005. Morocco's river basins (A) and total green (B), blue (C) and grey (D) water footprint of Morocco's production per river basin (in $10^{6} \mathrm{~m}^{3} / \mathrm{y}$ ). 
The monthly WF of storage reservoirs (in $\mathrm{m}^{3} / \mathrm{y}$ ) is calculated as the open water evaporation (in $\mathrm{m} / \mathrm{y}$ ) times the surface area of storage reservoirs (in $\mathrm{m}^{2}$ ). Data on open water evaporation from the reservoirs in the basins Loukkos, Sebou, Bouregreg and Oum Er Rbia is obtained from Ministry EMWE (unpublished data 2013) and for the other basins from a model simulation with the global hydrological model PCR-GLOBWB carried out by Sperna Weiland et al. (2010). The surface area of reservoirs at upper storage level is derived from Ministry EMWE (unpublished data 2013) and FAO (2013c). Since storage levels vary throughout the year (and over the years), and reservoir areas accordingly, this gives an overestimation of the evaporation from reservoirs. To counteract this overestimation, but due to lack of data on monthly storage level and reservoir area, for all months a fraction of the evaporation at upper storage level (43\%) is taken as estimate of the WF of storage reservoirs. This fraction represents the average reservoir area as fraction of its area at upper storage level, calculated as the average over the reservoirs in the basins Loukkos, Sebou, Bouregreg and Oum Er Rbia for which data on surface area at different reservoir levels is available from Ministry EMWE (unpublished data 2013).

The WF of the irrigation supply network refers to the evaporative loss in the network and is estimated based on a factor $K$, which is defined as the ratio of the blue WF of the irrigation supply network to the blue surface WF of crop production at field level (i.e. evaporation of irrigation water stemming from surface water). The blue WF of crop production at field level is taken from Mekonnen \& Hoekstra (2010b) and the split to surface water is made according to the fraction of irrigation water withdrawn from surface water (as opposed to groundwater) per river basin based on data from the associated river basin plans. $K$ is calculated as (see Appendix A.1):

$$
K=\left[\frac{1}{e_{\mathrm{a}} \times e_{\mathrm{c}}}-\frac{1}{e_{\mathrm{a}}}\right] \times f_{\mathrm{E}}
$$

in which $e_{a}$ represents the field application efficiency, $e_{c}$ the irrigation canal efficiency and $f_{\mathrm{E}}$ the fraction of losses in the irrigation canal network that evaporates (as opposed to percolates). The irrigation efficiencies $e_{\mathrm{a}}$ and $e_{\mathrm{c}}$ are estimated based on data from a local river basin agency and FAO (2013a). The value of $f_{\mathrm{E}}$ is assumed at fifty percent. The resultant $K$ for Morocco's irrigated agriculture as a whole is $15 \%$, i.e. the evaporative loss from the irrigation water supply network represents a volume equal to $15 \%$ of the blue surface WF of crop production at field level on average. 


\subsubsection{Water Footprint and Economic Water and Land Productivity of Crops}

The WF of crops per unit of production (in $\mathrm{m}^{3} / \mathrm{t}$ ) is calculated by dividing the WF per hectare (in $\mathrm{m}^{3} / \mathrm{ha} / \mathrm{y}$ ) by the yield (in $\mathrm{t} / \mathrm{ha} / \mathrm{y}$ ), for which data are obtained from Mekonnen \& Hoekstra (2010b). Economic water productivity (in US $\$ / \mathrm{m}^{3}$ ) represents the economic value of farm output per unit of water consumed and is calculated as the average producer price for the period 1996-2005 (in US\$/t) obtained from FAO (2013b) divided by the green plus blue WF (in $\mathrm{m}^{3} / \mathrm{t}$ ). Similarly, economic land productivity (in US\$/ha) represents the economic value of farm output per hectare of harvested land and is calculated as the same producer price multiplied by crop yield (in $\mathrm{t} / \mathrm{ha} / \mathrm{y}$ ), which is also obtained from Mekonnen \& Hoekstra (2010b).

\subsubsection{Virtual Water Flows and Associated Economic Value}

Green, blue and grey virtual water flows related to Morocco's import and export of agricultural and industrial commodities for the period 1996-2005 are obtained from Mekonnen \& Hoekstra (2011b), who estimated these flows at a global scale based on trade matrices and WFs of traded products at the locations of origin. The virtual water export that originates from domestic water resources (another part is re-export) is estimated based on the relative share of the WF within the nation to the total water budget:

$$
V_{\text {e,dom.res. }}=\frac{W F_{\text {national }}}{V_{\mathrm{i}}+W F_{\text {national }}} \times V_{\mathrm{e}}
$$

in which $W F_{\text {national }}$ is the WF within the nation (in $\mathrm{m}^{3} / \mathrm{y}$ ), $V_{\mathrm{i}}$ the virtual water import (in $\mathrm{m}^{3} / \mathrm{y}$ ) and $V_{\mathrm{e}}$ the virtual water export (in $\mathrm{m}^{3} / \mathrm{y}$ ).

The average earning per unit of water exported (in US $\$ / \mathrm{m}^{3}$ ) is calculated by dividing the value of export (in US\$/y) by virtual water export (in $\mathrm{m}^{3} / \mathrm{y}$ ). Similarly, the cost per unit of virtual water import is calculated by dividing the import value (in US\$/y) by virtual water import (in $\mathrm{m}^{3} / \mathrm{y}$ ). The average economic value of import and export for the period 1996-2005 are derived from the Statistics for International Trade Analysis (SITA) database from the International Trade Centre (ITC, 2007).

\subsubsection{Water Footprint versus Water Availability and Waste Assimilation Capacity}

To assess the environmental sustainability of the WF within Morocco, the total blue (surface- plus groundwater) WF of production is placed in the context of monthly natural runoff and the ground-WF in the context of annual groundwater availability. 
The water needed to assimilate the nitrogen fertilizers that reach the water systems due to leaching is compared with the waste assimilation capacity of aquifers.

The ground-WF is calculated by splitting the blue WF of crop production, industrial production and domestic water supply according to the fraction withdrawn from groundwater per river basin based on data from the associated river basin plans. Assuming that none of the water abstracted from groundwater for industrial production and domestic water supply returns (clean) to the groundwater in the same period of time, the ground-WFs of these purposes are increased to equal water withdrawal (as opposed to consumption) by dividing them by the consumptive fractions assumed by Mekonnen \& Hoekstra (2011b): 5\% for industries and 10\% for households.

Long-term average monthly natural runoff (1980-2011) for the river basins of Loukkos, Sebou, Bouregreg and Oum Er Rbia is derived from Ministry EMWE (unpublished data 2013). Natural runoff is estimated as the inflow of reservoirs. It is considered undepleted runoff, since large-scale blue water withdrawals come from the reservoirs. For the other basins, long-term average annual natural runoff is derived from the river basin plans for the respective river basins and subsequently distributed over the months according to intra-annual rainfall patterns (Riad, 2003; Tekken \& Kropp, 2012) or monthly natural discharge (JICA/MATEE/ABHT, 2007). Due to lack of data, for the Souss Massa basin the same monthly variation is applied as for the adjacent Tensift basin. Groundwater availability is assessed on river basin scale and defined as the recharge by percolation of rainwater and from rivers, minus the direct evaporation from aquifers. These data are obtained from the river basin plans and from Laouina (2001) for the basin of Souss Massa.

Blue water scarcity is defined as the ratio of the total blue WF in a catchment over the blue water availability in that catchment (Hoekstra et al., 2011). In this study, this ratio is calculated as the total blue WF to monthly natural runoff and as the ground-WF to annual groundwater availability. Following Hoekstra et al. (2012), blue water scarcity values have been classified into four levels of water scarcity. The classification in this study corresponds with their classification, with the note that the current study does not account for environmental flow requirements in the definition of blue water availability, since they are generally not considered in Morocco's river basin plans and local studies on the level of these requirements are lacking. This is compensated for by using stricter threshold values for the different scarcity levels, so that the resultant scheme is equivalent to that of Hoekstra et al. (2012): 
- low blue water scarcity $(<0.20)$ : the blue WF is lower than $20 \%$ of natural runoff; river runoff is unmodified or slightly modified.

- moderate blue water scarcity (0.20-0.30): the blue WF is between 20 and $30 \%$ of natural runoff; runoff is moderately modified.

- $\quad$ significant blue water scarcity (0.30-0.40): the blue WF is between 30 and $40 \%$ of natural runoff; runoff is significantly modified.

- severe water scarcity ( $>0.40)$ : the monthly blue WF exceeds $40 \%$ of natural runoff, so runoff is seriously modified.

The water pollution level is defined as the total grey WF in a catchment divided by the waste assimilation capacity (Hoekstra et al., 2011). In other words, it shows the fraction of actual runoff that is required to dilute pollutants in order to meet ambient water quality standards. A water pollution level greater than 1 means that ambient water quality standards are violated. The nitrate-related grey WF of crop production is assumed to mostly contribute to groundwater pollution and is therefore compared with the waste assimilation capacity of groundwater. As a measure of the latter, we use the actual groundwater availability, calculated as (natural) groundwater availability minus the ground-WF.

\subsubsection{Relocation of Crop Production and Reducing Water Footprints of Crops to Benchmark Levels}

The potential water savings by changing the pattern of crop production across river basins (which is possible due to spatial differences in crop water use) are quantified by means of an optimization model. The total green plus blue WF of twelve main crops in the country (in $\mathrm{m}^{3} / \mathrm{y}$ ) is minimized by changing the spatial pattern of production (in $\mathrm{t} / \mathrm{y}$ ) over the river basins under constraints for production demand (in t/y) and land availability (in ha/y). The analysed crops are: almonds, barley, dates, grapes, maize, olives, oranges, sugar beets, sugar cane, mandarins, tomatoes and wheat. Results are compared with a base case, which corresponds with the average green plus blue WF of the analysed crops over the period 1996-2005. Land availability is restricted per river basin and taken equal to the average harvested area in the period 1996-2005 obtained from Mekonnen \& Hoekstra (2010b). Two cases are distinguished: A) all crops can be relocated; B) only annual crops (barley, maize, sugar beets, tomatoes and wheat) can be relocated, perennials cannot. For both cases, the restriction is imposed that the total national production per crop (in $t / y$ ) should be equal to (or greater than) the total national production of the crop in the base case, which is defined as the average production in the period 1996-2005 obtained from Mekonnen \& Hoekstra (2010b). 
Table 2-2. Comparison of river basins based on reference evaporation ( $E_{0}$ in $\mathrm{mm} / \mathrm{y}$, period: 1961-1990).

\begin{tabular}{|clrc|}
\hline No. & River basin & $E_{0}(\mathrm{~mm} / \mathbf{y})$ & Considered comparable with no. \\
\hline 1 & Sud Atlas & 1,652 & - \\
2 & Souss Massa & 1,450 & 3 \\
3 & Moulouya & 1,409 & 2 \\
4 & Tensift & 1,389 & 5 \\
5 & Oum Er Rbia & 1,387 & 4 \\
6 & Sebou & 1,266 & $7 ; 8$ \\
7 & Bouregreg & 1,239 & $6 ; 8$ \\
8 & Loukkos & 1,212 & $6 ; 7$ \\
\hline
\end{tabular}

Source: E0 from FAO (2013d).

Additionally, an assessment is made of the potential water savings by reducing the WFs of the twelve main crops down to certain benchmark levels. For each basin and crop a benchmark is set in the form of the lowest water consumption (green plus blue) of that crop which is achieved in a comparable river basin in Morocco. In this case, basins are considered comparable when the reference evaporation $\left(E_{0}\right.$ in $\left.\mathrm{mm} / \mathrm{y}\right)$ is in the same order of magnitude (see Table 2-2). E0 expresses the evaporating power of the atmosphere at a specific location (and time of the year) and does not consider crop characteristics and soil factors (Hoekstra et al., 2011). Differences in soil and development conditions are thus not accounted for.

\subsection{Results}

\subsubsection{Water Footprint of Morocco's Production}

The total WF of Morocco's production in the period 1996-2005 was 38.8x106 m³/y (77\% green, $18 \%$ blue, $5 \%$ grey), see Table $2-3$. Crop production is the largest contributor to this WF, accounting for $78 \%$ of all green water consumed, $83 \%$ of all blue water consumed (evaporative losses in irrigation water supply network included) and $66 \%$ of the total volume of polluted water. Evaporative losses from storage reservoirs are estimated at $884 \times 10^{6} \mathrm{~m}^{3} / \mathrm{y}$, which is $13 \%$ of the total blue WF within Morocco. For most reservoirs, these losses are ultimately linked to irrigated agriculture and in some cases potable water supply. 
Table 2-3. Water footprint of Morocco's production in the period 1996-2005 (in $10^{6} \mathrm{~m}^{3} / \mathrm{y}$ ).

\begin{tabular}{|c|c|c|c|c|}
\hline Water footprint of & Green & Blue & Grey & Total \\
\hline Crop production ${ }^{a}$ & 23,245 & 5,097 & 1,378 & 29,719 \\
\hline Grazinga & 6,663 & - & - & 6,663 \\
\hline Animal water supply ${ }^{a}$ & - & 151 & - & 151 \\
\hline Industrial production ${ }^{a}$ & - & 18 & 69 & 88 \\
\hline Domestic water supplyb & - & 125 & 640 & 765 \\
\hline Storage reservoirs ${ }^{\mathrm{b}}$ & - & 884 & - & 884 \\
\hline Irrigation water supply network ${ }^{b}$ & - & 549 & - & 549 \\
\hline Total water footprint & 29,908 & 6,824 & 2,087 & 38,819 \\
\hline
\end{tabular}

Source: a Mekonnen \& Hoekstra (2011b); b Own elaboration.

Largest WFs (green, blue and grey) are found in the basins Oum Er Rbia and Sebou, the basins containing the main agricultural areas of Morocco (see Figure 2-1B-D). Together, these two basins account for $63 \%$ of the total WF of national production. In general, the green WF is largest in the rainy period December-May, while the blue WF is largest in the period April-September when irrigation water use increases.

In the basins Bouregreg and Loukkos, evaporation from storage reservoirs accounts for $45 \%$ and $55 \%$ of the total blue WF, respectively. Irrigated agriculture is the largest blue water consumer in the other basins, but evaporation from storage reservoirs is also significant in these basins. Main irrigated crops in the Oum Er Rbia basin are maize, wheat, olives and sugar beets, which together account for $60 \%$ of the total irrigation water consumed in the period 1996-2005. In the basin of Sebou, 56\% of the blue WF of crop production relates to the irrigation of wheat, olives, sugar beets, sugar cane and sunflower seed.

\subsubsection{Water Footprint and Economic Water and Land Productivity of Main Crops}

In the period 1996-2005, most green water was consumed by the production of wheat, barley and olives (Figure 2-2). The largest blue WFs relate to the production of wheat, olives and maize. For wheat, the number one blue water consuming crop, the blue WF was largest in the period March-May and peaked in April. 


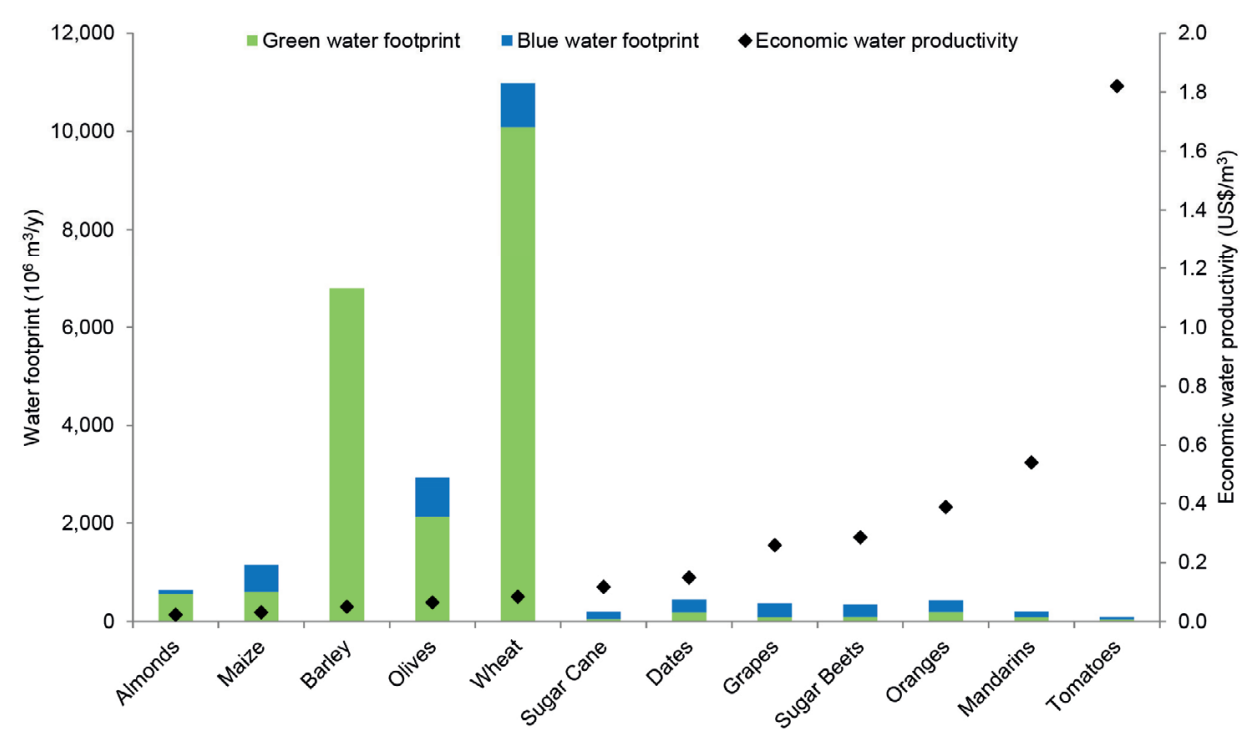

Figure 2-2. Economic water productivity and green and blue water footprint of main crops in Morocco. Period: 1996-2005. Source: Water footprint from Mekonnen \& Hoekstra (2010b), producer prices from FAO (2013b).

Water consumption of crops (green plus blue, in $\mathrm{m}^{3} / \mathrm{t}$ ) varies significantly per river basin due to differences in climatic conditions. In general, water consumption of crops is above country-average in the basins Oum Er Rbia and Tensift and below country-average in the northern basins Bouregreg, Sebou, Loukkos and Moulouya (Figure 2-3). In the basins Sud Atlas and Souss Massa the picture is not so clear, with some crops having above and others below country-average WFs (in $\mathrm{m}^{3} / \mathrm{t}$ ).

The five crops that consumed the most green plus blue water in the period 1996-2005 are the crops with the lowest economic water productivity, ranging from $0.08 \mathrm{US} \$ / \mathrm{m}^{3}$ for wheat to only $0.02 \mathrm{US} \$ / \mathrm{m}^{3}$ for almonds (Figure 2-2). Production of tomatoes yielded 22 times more value per drop than production of wheat. The same five crops also have the lowest economic land productivity, ranging from 375 US\$/ha for olives to 112 US $\$ /$ ha for almonds (Figure 2-4). The highest value per hectare cultivated was obtained by production of tomatoes. 


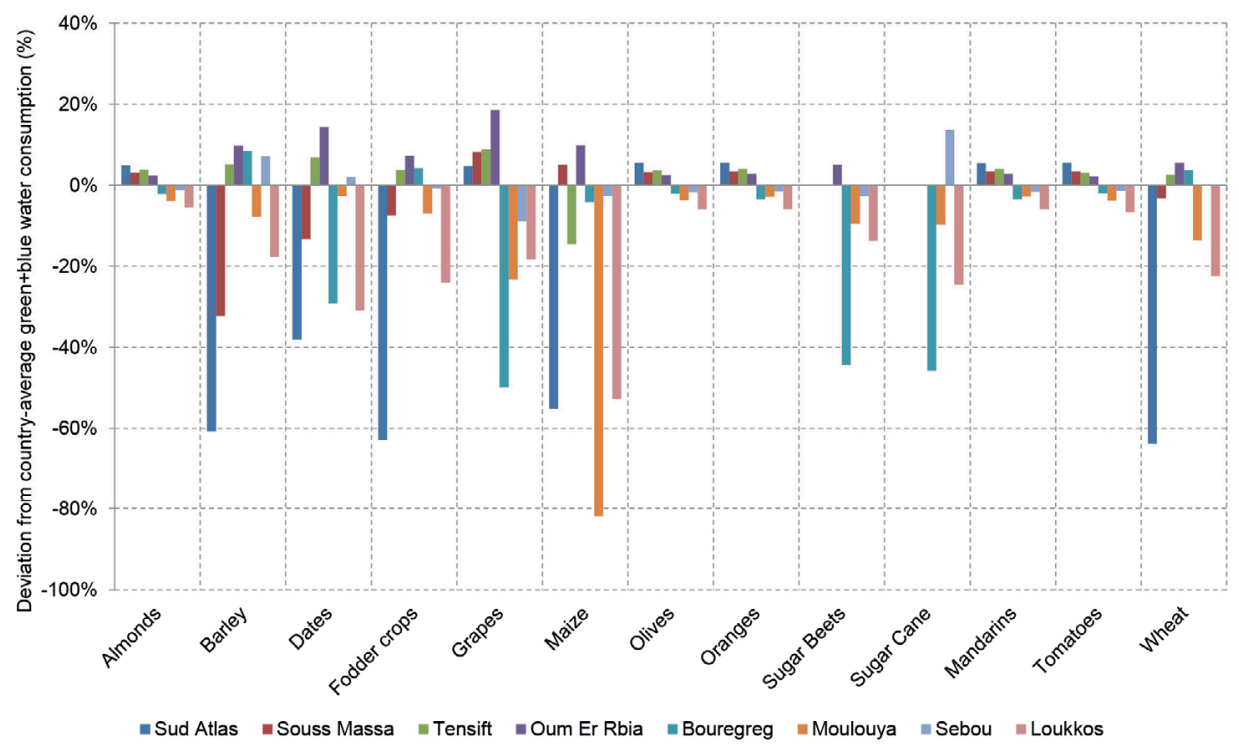

Figure 2-3. Variation in green plus blue water consumption (in $\mathrm{m}^{3} / \mathrm{t}$ ) across river basins. Period: 1996-2005.

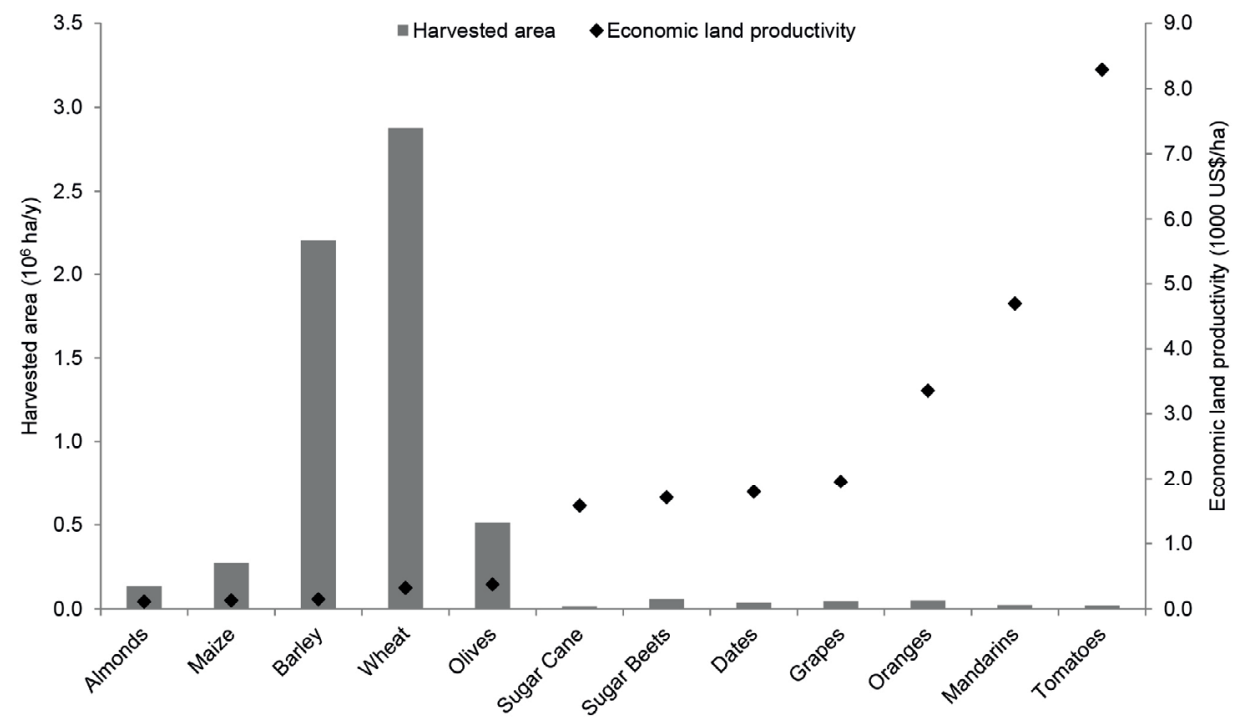

Figure 2-4. Economic land productivity and harvested area of main crops in Morocco. Period: 1996-2005. Source: Harvested area and yield from Mekonnen \& Hoekstra (2010b), producer prices from FAO (2013b). 


\subsubsection{Virtual Water Trade Balance of Morocco}

Morocco's virtual water trade balance for the period 1996-2005 is shown in Figure 2-5. Virtual water import exceeds virtual water export, which makes Morocco a net virtual water importer. Only 31\% of the virtual water export originates from Morocco's water resources, the other $69 \%$ is related to re-export of imported virtual water. By import of products instead of producing them domestically, Morocco saved $27.8 \mathrm{~km}^{3} / \mathrm{y}(75 \%$ green, $21 \%$ blue and $4 \%$ grey) of domestic water in the period $1996-2005$, equivalent to $72 \%$ of the WF within Morocco.

The value of the total virtual water imported in the period 1996-2005 was 12.4 billion US $\$$ y. Import of industrial products accounted for $83 \%$, import of crop products for $16 \%$ and import of animal products for $1 \%$. The average cost of imported commodities per unit of virtual water imported was $0.98 \mathrm{US} \$ / \mathrm{m}^{3}$. The value of the total virtual water exported in this period was 7.1 billion US\$/y (industrial products: 51\%, crop products: $48 \%$, animal products: $1 \%$ ). The average earning of exported commodities per unit of virtual water exported was $1.66 \mathrm{US} \$ / \mathrm{m}^{3}$.

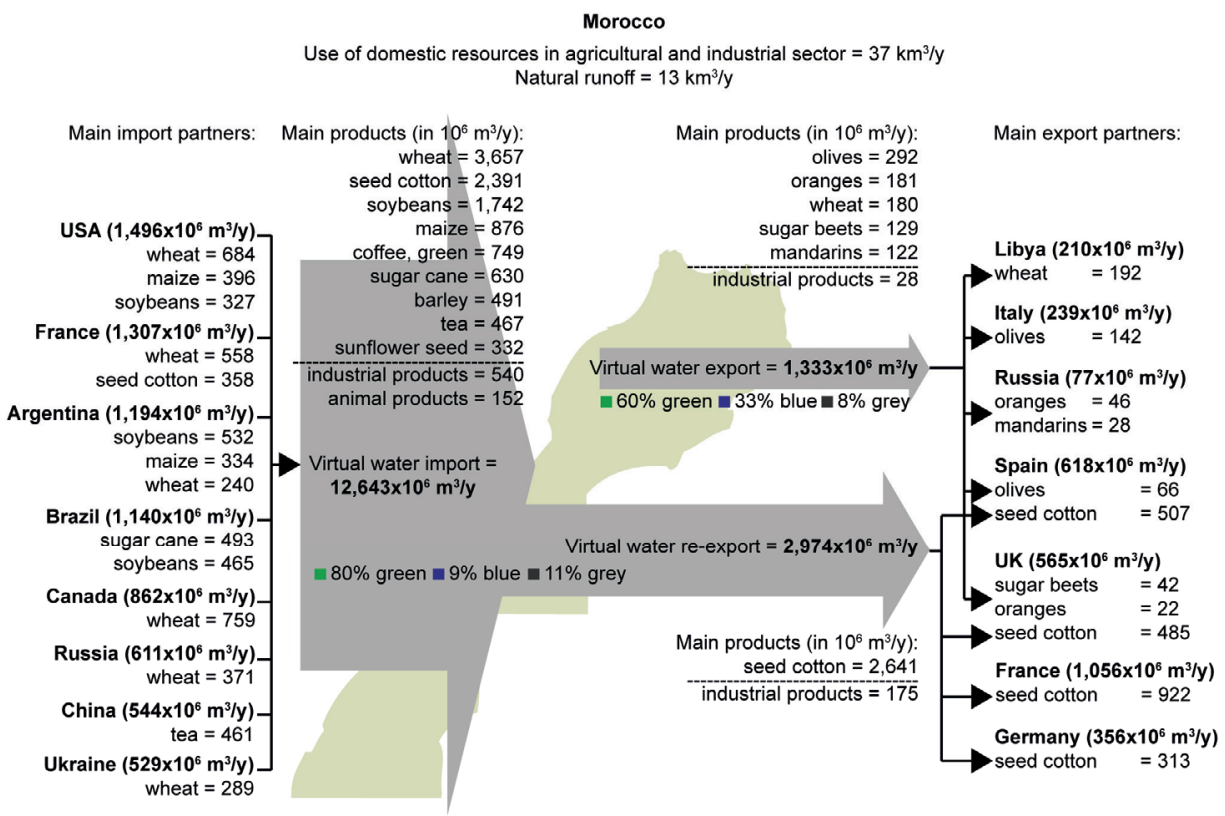

Figure 2-5. Morocco's virtual water trade balance related to trade in agricultural and industrial commodities. Period: 1996-2005. Source: Virtual water import and (total) virtual water export from Mekonnen \& Hoekstra (2011b). 
The total volume of Morocco's water virtually exported out of the country (i.e. excluding re-export) in the period 1996-2005 is estimated at $1,333 \times 10^{6} \mathrm{~m}^{3} / \mathrm{y}$. This means that about $4 \%$ of the water used in Morocco's agricultural and industrial sector is used for making export products. The remainder is used to produce products that are consumed by the inhabitants of Morocco. Virtual export of blue water from Morocco's resources was $435 \times 10^{6} \mathrm{~m}^{3} / \mathrm{y}$, which is to equivalent $3.4 \%$ of long-term average natural runoff $\left(13 \mathrm{~km}^{3} / \mathrm{y}\right)$.

Most of the virtual water export from Morocco's resources returns relatively little foreign currency per unit of virtual water exported. Export of crop products had the largest share in the virtual water export from Morocco's water resources $\left(1,305 \times 10^{6} \mathrm{~m}^{3} / \mathrm{y}\right)$, returning $0.87 \mathrm{US} \$ / \mathrm{m}^{3}$ on average. Specific crop products associated with large virtual water export from Moroccan origin are olives, oranges, wheat, sugar beets and mandarins. Out of these products, only export of mandarins $\left(122 \times 10^{6} \mathrm{~m}^{3} / \mathrm{y}\right)$ returned a value $\left(1.37 \mathrm{US} \$ / \mathrm{m}^{3}\right)$ larger than the average for crop products $\left(0.87 \mathrm{US} \$ / \mathrm{m}^{3}\right)$. On the other hand, virtual water export related to Moroccan tomatoes $\left(24 \times 10^{6} \mathrm{~m}^{3} / \mathrm{y}\right)$ yielded 7.13 $\mathrm{US} \$ / \mathrm{m}^{3}$.

\subsubsection{Water Footprint versus Water Availability and Waste Assimilation Capacity}

Blue water scarcity manifests itself in specific months of the year (Figure 2-6; Table 2-4). The average monthly water scarcity indicates severe water scarcity, more severe than annual (total) water scarcity values suggest. In all basins, the total blue WF exceeds natural runoff during a significant period of the year. In the months June, July and August, severe water scarcity occurs in all river basins. Crops with a large blue WF in July are: sugar beets in Oum Er Rbia and Sebou; grapes in the basins of Sud Atlas, Souss Massa and Oum Er Rbia; dates in Oum Er Rbia and Sebou; sunflower seed in the Sebou basin; maize in the basin of Oum Er Rbia. Demand for potable water peaks in the months June, July and August due to tourism and evaporation from storage reservoirs is large in these months due to the strong evaporative power of the atmosphere. Annual runoff in the Oum Er Rbia basin is almost completely consumed (inter-basin water transfers not yet considered), which raises the question whether it is wise to export water out of this basin to the basins of Bouregreg and Tensift as is common practice. 


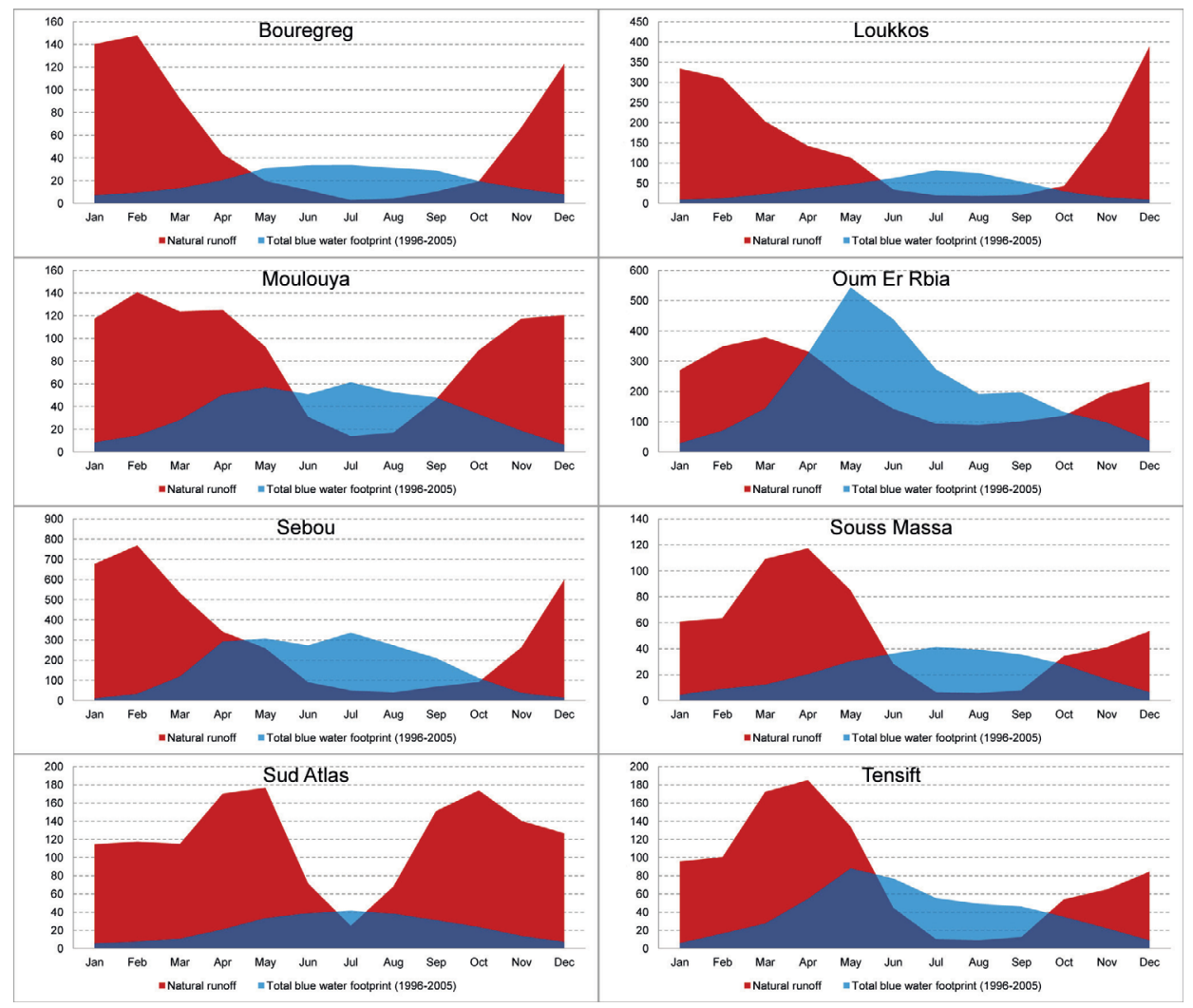

Figure 2-6. Total blue water footprint and natural runoff per river basin (both in $10^{6}$ $\mathrm{m}^{3} / \mathrm{month}$ ). Period of blue water footprint: 1996-2005. Natural runoff is estimated as the long-term average inflow of reservoirs. It is considered undepleted runoff, since largescale blue water withdrawals come from the reservoirs. The estimates can be considered conservative, because net precipitation in areas downstream of reservoirs is not included. Inter-basin water transfers (not included in data shown) are $212 \times 10^{6} \mathrm{~m}^{3} / \mathrm{y}$ from Oum Er Rbia to Tensift and 91x10 $\mathrm{m}^{3} / \mathrm{y}$ from Oum Er Rbia to Bouregreg. 


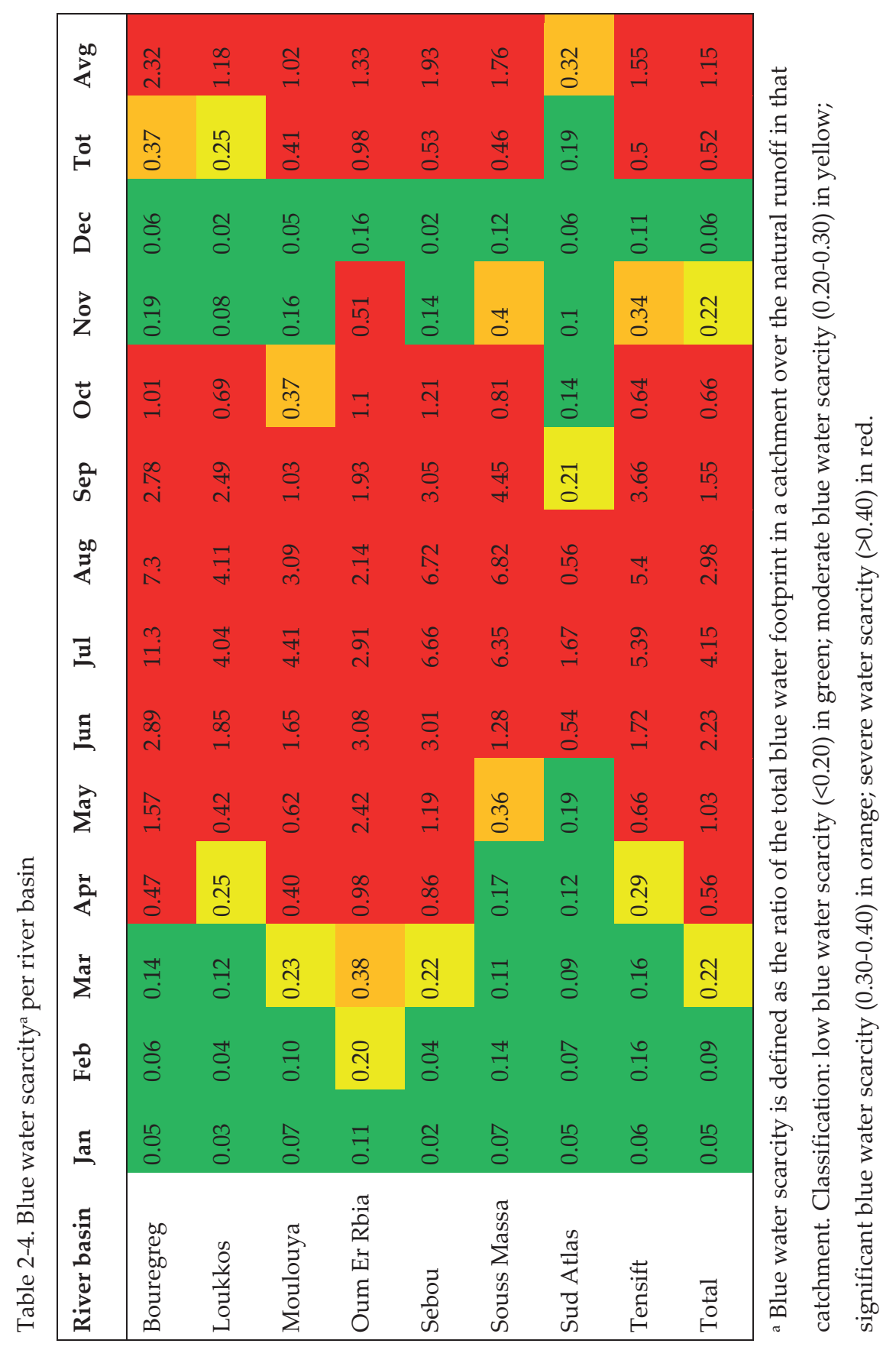


Table 2-5. Blue water scarcity related to groundwater. Basins are sorted top-down from highest to lowest scarcity.

\begin{tabular}{|c|c|c|c|c|}
\hline River basin & $\begin{array}{l}\text { Groundwater } \\
\text { footprint (1996- } \\
2005)\left(10^{6} \mathrm{~m}^{3} / \mathrm{y}\right)\end{array}$ & $\begin{array}{l}\text { Groundwater } \\
\text { availability } \\
\left(10^{6} \mathrm{~m}^{3} / \mathrm{y}\right)\end{array}$ & $\begin{array}{l}\text { Blue water } \\
\text { scarcity (-) }\end{array}$ & $\begin{array}{l}\text { Level of } \\
\text { water scarcity }\end{array}$ \\
\hline Bouregreg & 106 & 66 & 1.60 & Severe \\
\hline Tensift & 259 & 262 & 0.99 & Severe \\
\hline Oum Er Rbia & 510 & 667 & 0.77 & Severe \\
\hline Souss Massa & 219 & 349 & 0.63 & Severe \\
\hline Sebou & 689 & 1,502 & 0.46 & Severe \\
\hline Moulouya & 144 & 351 & 0.41 & Severe \\
\hline Loukkos & 93 & 377 & 0.25 & Moderate \\
\hline Sud Atlas & 137 & 697 & 0.20 & Moderate \\
\hline Total & 2,159 & 4,347 & & \\
\hline
\end{tabular}

The total ground-WF in Morocco constitutes about half of the country's groundwater availability (Table 2-5). Groundwater stress is severe in all river basins, except for the basins of Loukkos and Sud Atlas. In the Bouregreg basin, the annual ground-WF exceeds annual groundwater availability. As confirmed in the 2012 river basin plan for this basin, most of the aquifers in this basin are indeed overexploited, especially the main aquifers of Berrechid and Chaouia côtière.

In the Bouregreg basin there is no waste assimilation capacity of the groundwater left (because the blue ground-WF exceeds groundwater availability), which results in an infinite water pollution level (Table 2-6). In the basins of Tensift and Oum Er Rbia, waste assimilation capacity of the groundwater is also exceeded, even by 43 times the natural groundwater availability in the Tensift basin. These findings correspond with figures reported in the river basin plans for these three basins, which indicate severely high nitrate concentrations in the groundwater (at some measurement stations exceeding the maximum permissible limit in drinking water), mainly caused by diffuse nitrate pollution by the irrational use of nitrogen fertilizers, but in the case of the SahelDoukkala aquifer in the Oum Er Rbia basin also by the infiltration of untreated domestic wastewater. 
Table 2-6. Water pollution level related to nitrate-nitrogen in groundwater. Basins are sorted top-down from highest to lowest pollution level.

\begin{tabular}{|c|c|c|c|c|}
\hline River basin & $\begin{array}{l}\text { Grey water } \\
\text { footprint of crop } \\
\text { production } \\
(1996-2005) \\
\left(10^{6} \mathrm{~m}^{3} / \mathrm{y}\right)\end{array}$ & $\begin{array}{l}\text { Actual groundwater } \\
\text { availability } \\
\text { (= waste assimilation } \\
\text { capacity) } \\
\left(10^{6} \mathrm{~m}^{3} / \mathrm{y}\right)\end{array}$ & $\begin{array}{l}\text { Water } \\
\text { pollutio } \\
\text { n level } \\
(-)\end{array}$ & $\begin{array}{l}\text { Waste } \\
\text { assimilation } \\
\text { capacity } \\
\text { exceeded? }\end{array}$ \\
\hline Bouregreg & 148 & 0 & $\infty$ & Yes \\
\hline Tensift & 129 & 3 & 43.2 & Yes \\
\hline Oum Er Rbia & 435 & 157 & 2.78 & Yes \\
\hline Sebou & 428 & 813 & 0.53 & No \\
\hline Moulouya & 99 & 207 & 0.48 & No \\
\hline Souss Massa & 51 & 130 & 0.39 & No \\
\hline Loukkos & 63 & 284 & 0.22 & No \\
\hline Sud Atlas & 25 & 560 & 0.04 & No \\
\hline Total & 1,378 & 2,188 & 0.63 & No \\
\hline
\end{tabular}

\subsubsection{Reducing the Water Footprint of Crop Production in Morocco}

The regional differences in crop water use (Figure 2-3) provide an opportunity for reduction of the WF of crop production in Morocco. Potential water savings (green plus blue) are in the order of 1.9 and $1.2 \mathrm{~km}^{3} / \mathrm{y}$ when all crops (case A) and when only annual crops (case B) are relocated over the river basins, respectively (Table 2-7). Blue water savings are $1,276 \times 10^{6} \mathrm{~m}^{3} / \mathrm{y}$ in case $\mathrm{A}$ and $697 \times 10^{6} \mathrm{~m}^{3} / \mathrm{y}$ in case B. These are significant savings when put in the context of Morocco's national water strategy, which includes actions plans to mobilize $1.7 \mathrm{~km}^{3} / \mathrm{y}$ by 2030 through the construction of 60 large and 1000 small local dams and an additional $0.8 \mathrm{~km}^{3} / \mathrm{y}$ with the North-South inter-basin water transfer (Ministry EMWE, 2011). 
Table 2-7. Potential water savings by partial relocation of crop production per crop.

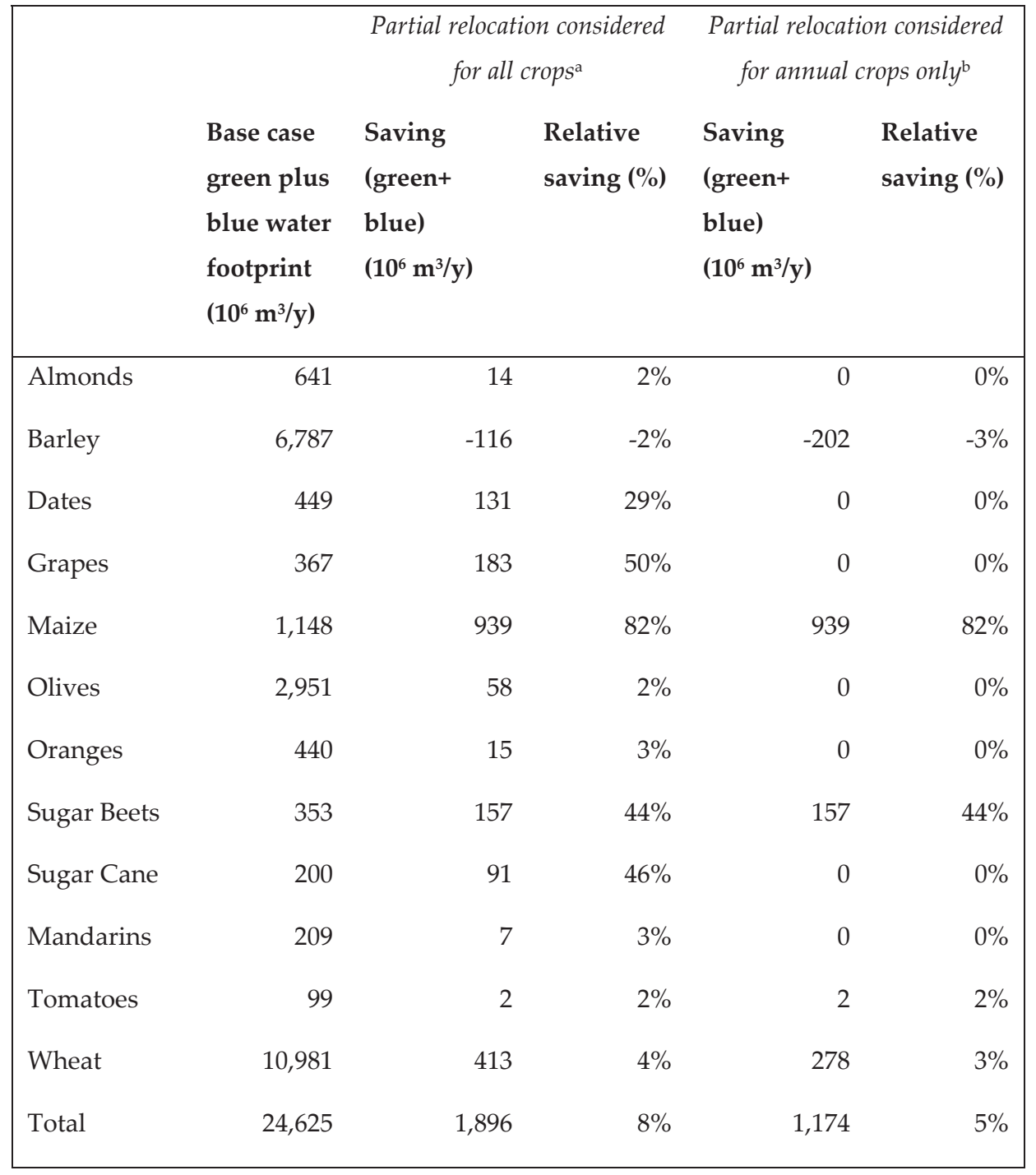

a All analysed crops are: almonds, barley, dates, grapes, maize, olives, oranges, sugar beets, sugar cane, mandarins, tomatoes and wheat.

${ }^{b}$ Annual crops are: barley, maize, sugar beets, tomatoes and wheat.

Largest potential water savings can be obtained by partial relocation of the production of maize and wheat (Table 2-7), particularly by moving maize production from the Oum Er Rbia basin to the Moulouya basin and wheat production from the Bouregreg basin to the basin of Sebou. 
Table 2-8. Potential water savings by partial relocation of crop production per river basin.

\begin{tabular}{|c|c|c|c|c|c|}
\hline & \multirow[b]{2}{*}{$\begin{array}{l}\text { Base case } \\
\text { green plus } \\
\text { blue water } \\
\text { footprint } \\
\left(10^{6} \mathrm{~m}^{3} / \mathrm{y}\right)\end{array}$} & \multicolumn{2}{|c|}{$\begin{array}{l}\text { Partial relocation considered } \\
\qquad \text { for all crops }{ }^{\mathrm{a}}\end{array}$} & \multicolumn{2}{|c|}{$\begin{array}{c}\text { Partial relocation considered } \\
\text { for annual crops only }\end{array}$} \\
\hline & & $\begin{array}{l}\text { Saving } \\
\text { (green+ } \\
\text { blue) } \\
\left(10^{6} \mathrm{~m}^{3} / \mathrm{y}\right)\end{array}$ & $\begin{array}{l}\text { Relative } \\
\text { saving (\%) }\end{array}$ & $\begin{array}{l}\text { Saving } \\
\text { (green+ } \\
\text { blue) } \\
\left(10^{6} \mathrm{~m}^{3} / \mathrm{y}\right)\end{array}$ & $\begin{array}{l}\text { Relative } \\
\text { saving (\%) }\end{array}$ \\
\hline Sud Atlas & 306 & 189 & $62 \%$ & 12 & $4 \%$ \\
\hline Souss Massa & 903 & 175 & $19 \%$ & 14 & $2 \%$ \\
\hline Tensift & 2,525 & 388 & $15 \%$ & 124 & $5 \%$ \\
\hline $\begin{array}{l}\text { Oum Er } \\
\text { Rbia }\end{array}$ & 8,498 & 1,229 & $14 \%$ & 821 & $10 \%$ \\
\hline Bouregreg & 2,813 & -994 & $-35 \%$ & -95 & $-3 \%$ \\
\hline Moulouya & 1,737 & 605 & $35 \%$ & 412 & $24 \%$ \\
\hline Sebou & 6,905 & 154 & $2 \%$ & -95 & $-1 \%$ \\
\hline Loukkos & 939 & 151 & $16 \%$ & -19 & $-2 \%$ \\
\hline Total & 24,625 & 1,896 & $8 \%$ & 1,174 & $5 \%$ \\
\hline
\end{tabular}

a All analysed crops are: almonds, barley, dates, grapes, maize, olives, oranges, sugar beets, sugar cane, mandarins, tomatoes and wheat.

b Annual crops are: barley, maize, sugar beets, tomatoes and wheat.

Partial relocation of crop production in case A results in decreased WFs (green plus blue) in all basins, except for the basin of Bouregreg where the WF increases (Table 2-8). In case B, the WFs in the basins Bouregreg, Sebou and Loukkos increase, particularly due to increased wheat production in these basins, while the WFs in the other basins decrease. Precipitation in the basins of Sebou and Loukkos is generally larger than in other parts of Morocco (Ministry EMWE, 2011). 
Table 2-9. Potential water savings per river basin by benchmarking water productivities of main $\operatorname{crops}^{\mathrm{a}}$ (in $10^{6} \mathrm{~m}^{3} / \mathrm{y}$ ).

\begin{tabular}{|c|c|c|c|c|c|c|c|c|c|}
\hline & 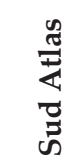 & 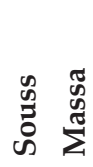 & 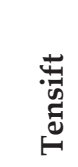 & 章 & 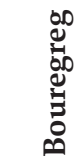 & $\frac{\tilde{2}}{3}$ & $\begin{array}{l}\tilde{0} \\
\text { के }\end{array}$ & $\frac{\text { o }}{\underline{y}}$ & 胥 \\
\hline Almonds & 0 & 2 & 1 & 0 & 3 & 0 & 8 & 0 & 14 \\
\hline Barley & 0 & 0 & 0 & 100 & 158 & 222 & 238 & 0 & 717 \\
\hline Dates & 0 & 0 & 0 & 10 & 0 & 4 & 48 & 0 & 63 \\
\hline Grapes & 0 & 20 & 0 & 5 & 0 & 0 & 18 & 4 & 48 \\
\hline Maize & 0 & 13 & 0 & 175 & 32 & 0 & 33 & 0 & 254 \\
\hline Olives & 0 & 9 & 4 & 0 & 10 & 0 & 35 & 0 & 59 \\
\hline Oranges & 0 & 1 & 1 & 0 & 1 & 0 & 6 & 0 & 9 \\
\hline Sugar Beets & 0 & 0 & 0 & 0 & 0 & 0 & 70 & 4 & 73 \\
\hline Sugar Cane & 0 & 0 & 0 & 0 & 0 & 0 & 79 & 10 & 89 \\
\hline Mandarins & 0 & 1 & 0 & 0 & 0 & 0 & 3 & 0 & 4 \\
\hline Tomatoes & 0 & 0 & 0 & 0 & 1 & 0 & 1 & 0 & 3 \\
\hline Wheat & 0 & 14 & 0 & 102 & 417 & 0 & 904 & 0 & 1,436 \\
\hline Total (gn+bl) & 0 & 60 & 6 & 392 & 623 & 226 & 1,444 & 18 & 2,768 \\
\hline Total (blue) ${ }^{\mathrm{b}}$ & 0 & 23 & 2 & 113 & 11 & 2 & 258 & 12 & 422 \\
\hline $\begin{array}{l}\text { Total (blue) } \\
\text { (\% of natural } \\
\text { runoff) }\end{array}$ & $0 \%$ & $4 \%$ & $0 \%$ & $4 \%$ & $2 \%$ & $0 \%$ & $7 \%$ & $1 \%$ & $3 \%$ \\
\hline
\end{tabular}

a Analysed crops are: almonds, barley, dates, grapes, maize, olives, oranges, sugar beets, sugar cane, mandarins, tomatoes and wheat.

${ }^{b}$ Assuming that the green/blue water ratio remains the same for all basins and crops. 
Reducing the WFs of crops to benchmark levels leads to a potential green plus blue water saving of $2,768 \times 10^{6} \mathrm{~m}^{3} / \mathrm{y}$, a reduction of $11 \%$ (Table 2-9). Fifty-two per cent of this saving is related to reduced WFs (i.e. improved water productivities) in the Sebou basin alone. Largest potential water savings are associated with reducing the WFs of cereals, especially wheat. Blue water savings are estimated at $422 \times 10^{6} \mathrm{~m}^{3} / \mathrm{y}$ and are largest in the basins of Sebou and Oum Er Rbia.

\subsubsection{Added Value of Water Footprint Assessment for Morocco's Water Policy}

Several insights and response options emerged from the Water Footprint Assessment, which are currently not considered in the national water strategy of Morocco and the country's river basin plans. They include:

i. New insights in the water balance of Morocco and the country's main river basins:

- The evaporative losses from storage reservoirs account for a significant part of the blue WF within Morocco. This sheds fresh light on the national water strategy that proposes to build another 60 large and 1000 small dams by 2030 .

- Blue water scarcity on a monthly scale is severe and hidden by annual analysis of demand versus supply, which is the common scale of analysis in Morocco's river basin plans.

ii. New insights in how economically efficient water and land resources are used:

- Analysis of the economic value of crop products per unit of water and land used in the period 1996-2005 indicate that agricultural policy may be better brought in line with water policy by reconsidering which crops to grow.

- It is shown that the export policy in this period was not optimal from a watereconomics point of view, which raises the question whether the foreign income generated by export covers the direct and indirect costs of mobilization and (over)exploitation of Morocco's water resources. This might not be the case considering the costs of the construction and maintenance of the large dams and intra- and inter-basin water transfers in the country and the costs associated with the negative externalities of water (over)consumption, such as the salt-intrusion in Morocco's coastal aquifers.

iii. New response options to reduce the WF of crop production:

- Analysis of the WF of the main crops in Morocco and its variation across the river basins offers new ways of looking at reducing water consumption in the 
agricultural sector. The estimated potential water savings by partial relocation of crops to basins where they consume less water and by reducing WFs of crops down to benchmark levels are significant compared to demand reducing and supply increasing measures considered in the national water strategy of Morocco.

\subsection{Discussion}

Morocco's WF is mostly green (77\%). This underlines the importance of green water resources, also (or especially) in semi-arid countries with a high dependency on blue water, and is in line with other studies showing the dominance of the green over the blue water flow in Africa (and most of the world) (Rockström et al., 2009; Schuol et al., 2008). The relevance of the green WF should not be underestimated. Although rain is free and evaporation happens anyway, green water that is used for one purpose cannot be used for another purpose (Hoekstra, 2013).

Storage reservoir evaporation accounts for a significant share $(13 \%)$ in the blue WF in Morocco. The need for seasonal storage of water is evident given the large mismatch in natural runoff and water demand (Figure 2-6). However, the large evaporation from reservoirs shows that these should be seen as water consumers, besides their role in water supply. This WF can ultimately be linked to the end-purpose of the reservoir, which for most cases in Morocco is primarily serving irrigated agriculture. Therefore, to reduce the need for seasonal storage and hence the WF of storage reservoirs, it would be worthwhile to take the timing of crop water demands with respect to natural water availability into account in deciding which crops or crop varieties to grow. Furthermore, local alternatives to the large surface water reservoirs are groundwater dams, which enhance underground water storage in alluvial aquifers and thereby loose less water by evaporation (Al-Taiee, 2012).

Our analysis shows that from a strictly water-economics point of view it would be worthwhile to reconsider which crops to grow in Morocco (due to the low value in $\mathrm{US} \$ / \mathrm{m}^{3}$ and US $\$ /$ ha for some crops compared to others). In practice, the choice of which crops to produce is part of the national strategy regarding food security and of course closely linked to the demand for crops (national and global). Nevertheless, we consider it useful and important to analyse economic water and land productivities (as done in this study) in addition to these considerations. Especially for water-short countries as Morocco it is relevant to evaluate the economic efficiency of water allocation. This also relates to the question whether the foreign income generated by export products, which 
have a footprint on national resources, outweighs the direct and indirect costs associated with the resource use.

\subsubsection{Uncertainties and Limitations}

The WF of crop production is largely influenced by the input data used and assumptions made by Mekonnen \& Hoekstra (2010b) and can easily contain an uncertainty of $\pm 20 \%$ (Mekonnen \& Hoekstra, 2010b; Mekonnen \& Hoekstra, 2010a; Hoff et al., 2010). The calculated economic water and land productivities of crops are, apart from the WFs and yields, dependent on the producer prices. Variations in these prices largely influence the economic water and land productivity of crops. The WFs of industrial production and domestic water supply are very sensitive to the consumptive fractions applied.

Although figures on water availability are based on data from the river basin plans and the Ministry EMWE (unpublished data 2013), the way they are estimated exactly is often unclear and so is the uncertainty in them. Since natural runoff is estimated as the inflow of reservoirs (thus excluding small-scale local abstractions upstream) and net precipitation in areas downstream of reservoirs is not included, the estimates of natural runoff can be considered conservative.

In general, the river basin plans indicate larger pressure on groundwater resources than suggested in this study. This might be caused by the fact that the river basin plans include more recent withdrawals and because the unit of analysis in this study (river basin agency action zone) is larger than the unit used in the river basin plans (individual aquifers), whereby in this study overexploitation of one aquifer might be masked by low exploitation of another. Also local groundwater pollution according to the river basin plans is sometimes worse than the water pollution level estimated here. This could be explained by the fact that the water quality measurements recorded in the basin plans are partly more recent and are measured at specific points, whereas this study considered homogeneous distribution of nitrates in the groundwater.

Given the uncertainties and limitations of the study, the presented WF estimates and water scarcity values should be interpreted with care. Nevertheless, the order of magnitude of the estimates in this study gives a good indication to which activities and crops Morocco's water resources are allocated, in which months and basins the WFs are relatively large or small and where and when this leads to highest water scarcity.

Uncertainties in the estimated potential savings by relocation of crop production and reducing the WFs of crops to benchmark levels are closely linked to the uncertainties in the estimates of the WF of crop production and the results should be interpreted 
carefully. However, the order of magnitude of the estimated savings gives a rough indication of the potential of these measures. When considering relocation of crop production it is necessary to assess how the green and blue WFs of crops manifest themselves on a monthly scale. This study looked at annual water savings, but the associated relocation of crops might well aggravate monthly water scarcity in some river basins. Furthermore, the feasibility and desirability of relocation of crop production are of course largely determined by social and economic factors which are not considered in this study.

\subsection{Conclusion}

The study finds that: (i) evaporation from storage reservoirs is the second largest form of blue water consumption in Morocco, after irrigated crop production; (ii) Morocco's water and land resources are mainly used to produce relatively low-value (in US $\$ / \mathrm{m}^{3}$ and US\$/ha) crops such as cereals, olives and almonds; (iii) most of the virtual water export from Morocco relates to the export of products with a relatively low economic water productivity (in US\$/ $\mathrm{m}^{3}$ ); (iv) blue water scarcity on a monthly scale is severe in all river basins and pressure on groundwater resources by abstractions and nitrate pollution is considerable in most basins; (v) the estimated potential water savings by partial relocation of crops to basins where they consume less water and by reducing WFs of crops down to benchmark levels are significant compared to demand reducing and supply increasing measures considered in Morocco's national water strategy.

On the basis of these new insights and response options it is concluded that Water Footprint Assessment has an added value for national water policy in Morocco. Water Footprint Assessment forces to look at end-users and -purposes of freshwater, which is key in determining efficient and equitable water allocation within the boundaries of what is environmentally sustainable, both on the river basin and on the national level. This is especially relevant for water-scarce countries such as Morocco. Furthermore, considering the green and grey components of a WF provides new perspectives on blue water scarcity, because pressure on blue water resources might be reduced by more efficient use of green water and by less pollution. 


\title{
3. Mitigating the Risk of Extreme Water Scarcity and Dependency: The Case of Jordan ${ }^{3}$
}

\begin{abstract}
Jordan faces great internal water scarcity and pollution, conflict over transboundary waters, and strong dependency on external water resources through trade. This paper analyses these issues and subsequently reviews options to reduce the risk of extreme water scarcity and dependency. Based on estimates of water footprint, water availability, and virtual water trade, we find that groundwater consumption is nearly double the groundwater availability, water pollution aggravates blue water scarcity, and Jordan's external virtual water import dependency is $86 \%$. The review of response options yields 10 ingredients for a strategy for Jordan to mitigate the risks of extreme water scarcity and dependency. With respect to these ingredients, Jordan's current water policy requires a strong redirection towards water demand management. Actual implementation of the plans in the national water strategy (against existing oppositions) would be a first step. However, more attention should be paid to reducing water demand by changing the consumption pattern of Jordanian consumers. Moreover, unsustainable exploitation of the fossil Disi aquifer should soon be halted and planned desalination projects require careful consideration regarding the sustainability of their energy supply.
\end{abstract}

\subsection{Introduction}

The water situation in Jordan is complex and unsustainable. Jordan experiences growing freshwater demands that already exceed availability and surface and groundwater resources are polluted (Scott et al., 2003; Mohsen, 2007; Van Aken et al., 2009; Alqadi \& Kumar, 2014, 2011; Hadadin et al., 2010; Becker et al., 2014). At the same time, Jordan heavily relies on water resources outside its borders, in physical sense through the sharing of rivers and aquifers with neighbouring countries as well as in indirect sense through Jordan's strong dependence on virtual water imports (Hoekstra \& Mekonnen, 2012). Sharing water resources with Israel and Syria has led to tensions in the past (Medzini \& Wolf, 2004; Schenker, 2014; Namrouqa, 2012; Gleick, 2014). On top of this, Jordan has experienced large influxes of refugees as a result of the ongoing conflicts in the surrounding countries (Gleick, 2014; de Chatel, 2014), which increases Jordan's

${ }^{3}$ This chapter has been published as:

Schyns, J.F., Hamaideh, A., Hoekstra, A.Y., Mekonnen, M.M., \& Schyns, M. (2015) Mitigating the risk of extreme water scarcity and dependency: the case of Jordan, Water, 7(10): 5705-5730. 
struggle to meet domestic water needs (Scott et al., 2003; Mohsen, 2007; Hadadin et al., 2010; Abu-Shams \& Rabadi, 2003; Alqadi \& Kumar, 2011, 2014; Talozi et al., 2015).

Jordan is partly arid and partly semi-arid (Toernros \& Menzel, 2014; Hadadin et al., 2010; Alqadi \& Kumar, 2011; Jaber \& Mohsen, 2001) and therefore has natural low water availability. Climate change has caused a decline in precipitation and hence surface water flows (Hadadin et al., 2010; Alqadi \& Kumar, 2014). Based on model simulations for different climate change scenarios, Abdulla et al. (2009) found that decreases in precipitation will lead to significant decreases in runoff and groundwater recharge in the Zarqa river basin (Figure 3-1). The percentage of time that the Jordan River basin and its surroundings will experience moderate, severe and extreme drought conditions is expected to increase in the future (Toernros \& Menzel, 2014). Such droughts can have devastating effects when agricultural and water management practices in place are unsustainable (Kelley et al., 2015). Furthermore, the (semi-)arid conditions in the Jordan Valley, characterized by a combination of high potential evaporation and low precipitation, causes a lack of salt flushing and leaching of agricultural soils leading to alarming soil salinity levels (Ammari et al., 2013).

Naturally low water availability in Jordan is reduced further by (over)consumption of shared surface water resources by upstream and neighbouring countries. Both the Jordan River and the Yarmouk River have been depleted by upstream (over)consumption in Israel and Syria (Mohsen, 2007; Hadadin et al., 2010; Alqadi \& Kumar, 2014; Haddadin, 2009). The sharing of transboundary water resources has led to difficulties and tensions. In 1994, Jordan and Israel signed a Peace Treaty which included agreements on water allocations (Haddadin, 2011). Jordan is allowed a certain outflow from Lake Tiberius (situated in Israel) into the Lower Jordan River. The current national water strategy of Jordan assumes $50 \times 10^{6} \mathrm{~m}^{3} / \mathrm{y}$ of water to be secured by the Peace Treaty (Ministry of Water and Irrigation (MWI), 2009). When in 1999 the region was struck by a drought event, the agreed water allocation was threatened and bilateral talks temporarily broke down before the two parties found a resolution in the end (Medzini \& Wolf, 2004; Schenker, 2014). With minimal outflow from Lake Tiberius controlled by Israel, the Lower Jordan River mainly depends on inflow from its main tributary the Yarmouk River (Van Aken et al., 2009). The Yarmouk River is shared by Jordan, Syria and Israel (Kliot, 2005). Jordan and Syria signed an agreement on sharing the Yarmouk's water in 1987 (Kliot, 2005; Namrouqa, 2012). Nevertheless, the countries have had continued tensions over the construction and operation of Syrian dams on the river 
(Gleick, 2014). In 2012, The Jordan Times (Namrouqa, 2012) reported that Syria violated the agreement, thereby depriving Jordan of its legitimate water share.

Current water demand in Jordan exceeds the limited renewable water resources available in the country. Agricultural water demand is growing (by 38\% in the period 2000-2010 (Alqadi \& Kumar, 2014)) despite efforts to improve irrigation efficiency and encouraging farmers to grow less water-intensive crops (Scott et al., 2003). Domestic water demand is unmet and still increasing (by 40 to $46 \%$ in the period 2000-2010 (Hadadin et al., 2010; Alqadi \& Kumar, 2014)). This increase is due to rapid population growth, caused by a high rate of natural population growth and periodic massive influxes of refugees (Scott et al., 2003; Mohsen, 2007; Hadadin et al., 2010; Alqadi \& Kumar, 2011; Talozi et al., 2015). In 2014, the refugee population in Jordan, mostly consisting of Syrians, was around 10\% of the country's total population (Figure 3-2). These are officially registered refugees only and the actual number is likely to be higher. Since the conflicts in Syria, Iraq and Israel/Palestine are still ongoing, there is all the reason to believe that the number of people seeking refuge in Jordan is still growing.

Overconsumption of Jordan's surface and groundwater resources is associated with several environmental impacts. Due to the high amount of abstractions along its course, the Jordan River has shrunk to a small creek by the time it reaches the Dead Sea, with current discharge being less than 5\% of historical levels (Hadadin et al., 2010; Becker et al., 2014). This has led to an alarming decline of the Dead Sea level, which in turn causes lowering of groundwater tables in adjacent aquifers (Alqadi \& Kumar, 2014). Since the 1970s, the water level of the Dead Sea has dropped at a rate of about 1 meter per year (Abu Qdais, 2008; Abu Ghazleh et al., 2009). With each meter of reduction, $300 \times 10^{6} \mathrm{~m}^{3}$ of fresh water is lost from neighbouring aquifers (Abu Qdais, 2008). Groundwater levels are rapidly dropping throughout the country (Mohsen, 2007; Alqadi \& Kumar, 2011; Scott et al., 2003). This has led to drying up of springs and disappearance of the Azraq wetlands (Van Aken et al., 2009) with reduced habitat for endemic species and migratory birds as a consequence (Scott et al., 2003).

Problems of surface and groundwater pollution are widespread in Jordan, which aggravates water scarcity (Schyns et al., 2015). Inadequate treatment of industrial and domestic wastewater and over- and misuse of fertilizers and pesticides pollute these resources (Hadadin et al., 2010; Scott et al., 2003; Al-Zu'bi, 2007). The canals that distribute water throughout Jordan are more and more polluted by salts and other agricultural runoff (Alqadi \& Kumar, 2014). Pollution of groundwater is exacerbated by overpumping, which leads to a concentration of salts and other pollutants (Jaber \& 
Mohsen, 2001; Scott et al., 2003; Venot \& Molle, 2008; El-Naqa \& Al-Shayeb, 2009; Alqadi \& Kumar, 2013; Al-Ansari et al., 2014). Hotspots of groundwater pollution in the regions of Amman, Zarqa and Balqa have been mapped by Alqadi et al. (2014). The pollution of waters in Jordan is also partially a transboundary issue. The Jordan River Basin suffers by agricultural runoff and untreated wastewater from all riparian countries (Scott et al., 2003).

Jordan thus faces great internal water scarcity and pollution, conflict over transboundary waters and great dependency on external water resources through trade. Given the great variety of challenges, sustainable water management in Jordan is a challenging task, which thus far has not succeeded. The objective of this paper is to analyse Jordan's domestic water scarcity and pollution and the country's external water dependency, and subsequently review options to reduce the risk of extreme water scarcity and dependency. In the next section we discuss methods and data. In the third section we analyse the water situation in Jordan from a water footprint (WF) perspective, with the aim to accurately quantify the severity of water scarcity and pollution in Jordan. In the fourth section, we analyse the country's dependency on external water resources by quantifying and mapping the world-wide water consumption associated with the products and commodities Jordanians consume. In the fifth section, we review possible response options to Jordan's water problems and external water dependency. 

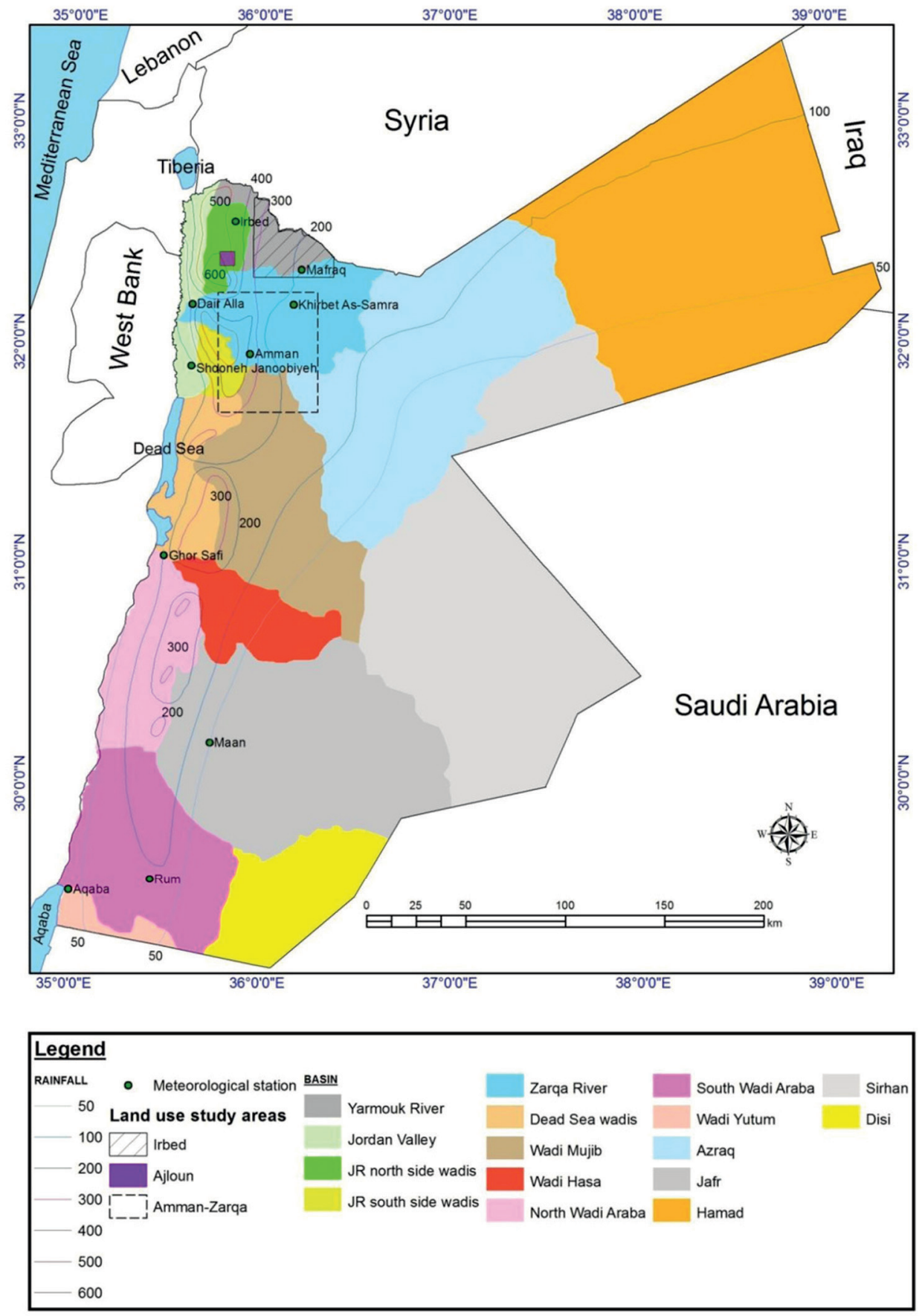

Figure 3-1. Map of Jordan with surface water basins and rainfall isohyets. Source: AlBakri et al. (2013). 


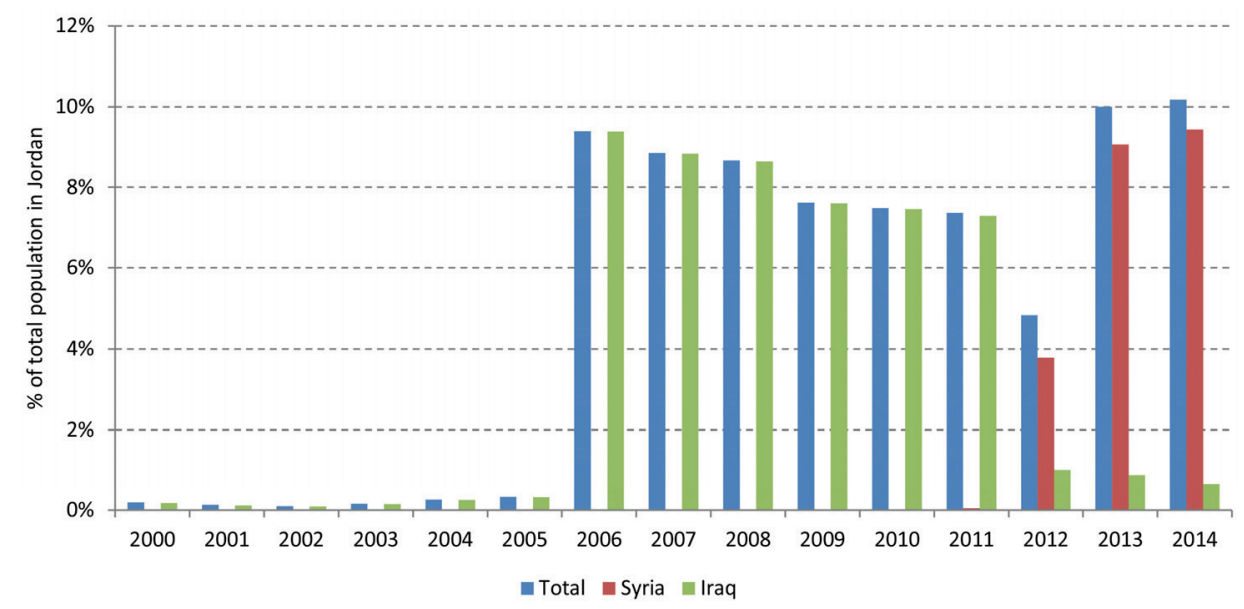

Figure 3-2. Refugees and asylum seekers in Jordan as percentage of the total population in Jordan. Data: total population from World Bank (2015); refugee and asylum seekers population from United Nations High Commissioner for Refugees (UNHCR) (2015).

\subsection{Methods and Data}

We estimate WFs of production and consumption and virtual water trade following the global standard for Water Footprint Assessment (Hoekstra et al., 2011). We quantify the WF of five different sectors in Jordan: crop production, grazing, animal water supply, industrial production and domestic water supply. Therein we distinguish three different WFs: green, blue and grey. The green WF refers to the appropriation of the green water flow (i.e. evaporation of precipitation stored in the soil moisture and on top of vegetation) in crop production and grazing systems. The blue WF expresses the consumptive use of surface- and groundwater (blue water resources), which excludes return flows to these resources. The grey WF expresses water pollution in the same unit as water consumption. It measures the volume of freshwater required to dilute the pollutants that enter blue water resources to such an extent that ambient water quality standards are not violated.

We estimate the WF of crops in Jordan for the period 1996-2005 following the method of and using the same underlying datasets as Mekonnen \& Hoekstra (2011a). The grey WF of crop production is calculated based on leaching of nitrogen to the groundwater, assuming an ambient water quality standard of $10 \mathrm{mg} / \mathrm{l}$ of nitrate-nitrogen ( $\left.\mathrm{NO}_{3}-\mathrm{N}\right)$. The WF of grazing and the domestic and industrial sectors as well as imported and exported virtual water volumes are estimated following the methods of Hoekstra \& Mekonnen (2012). The grey WFs of the industrial and domestic sectors relate to the aggregate of pollutants, but are conservative estimates since we take the part of the return flow which 
is disposed into the environment without prior treatment as a measure of the grey WF (thus assuming a dilution factor of 1), following Hoekstra \& Mekonnen (2012).

The WF of Jordan's consumption, defined as the volume of water consumed to produce all the products consumed by the Jordanian population, inside and outside Jordan, is calculated following Hoekstra \& Mekonnen (2012). The national water saving through trade is the volume of water that Jordan saved by importing products instead of producing them domestically, and is calculated following Mekonnen \& Hoekstra (2011b).

The total blue WF of each sector is split into a part originating from surface water (i.e. blue surface-WF) and a part originating from groundwater (i.e. blue ground-WF). This was done according to the origin of blue water use per sector (groundwater versus surface water) which we obtained from Alqadi \& Kumar (2014). We scaled the estimated ground-WFs of industries and households to equal water withdrawals based on the consumptive use fraction following Schyns \& Hoekstra (2014). The underlying assumption is that none of the water abstracted from groundwater for industrial production and domestic water supply returns (clean) to the groundwater in the same period of time.

Blue water scarcity is calculated as the ratio of the total blue WF in Jordan over total blue water availability (Hoekstra et al., 2011). Total blue water availability is defined as the total renewable surface and groundwater resources, as defined by the FAO (2015a). We assess blue water scarcity for the sum of surface and groundwater, but also for groundwater separately. Jordan's renewable surface water resources are estimated by taking the sum of treaty allocations and surface run-off produced internally. Groundwater availability is defined as the groundwater recharge minus the fraction of natural groundwater outflow required to sustain environmental flow requirements in the river (Hoekstra et al., 2011). In practice, groundwater availability in Jordan is often reported as the "safe yield" of groundwater without further clarification (Hadadin et al., 2010; Mohsen, 2007; Ministry of Water and Irrigation (MWI), 2009; El-Naqa \& Al-Shayeb, 2009; Ministry of Water and Irrigation (MWI), 2013). The FAO (2015a) defines "safe yield" as the amount of water (in general, the long term average amount) which can be withdrawn from the groundwater without causing undesirable results. Although it is a vague concept (Dottridge \& Abu Jaber, 1999; Sophocleous, 2000), we take reported figures on safe yield (Hadadin et al., 2010; Mohsen, 2007; Ministry of Water and Irrigation (MWI), 2009; El-Naqa \& Al-Shayeb, 2009; Ministry of Water and Irrigation (MWI), 2013) as a proxy for groundwater availability, due to lack of data. We consider 
Jordan's blue water availability around the year 2000 as proper context for the WF estimates that relate to the period 1996-2005. We use the water scarcity classification by Schyns \& Hoekstra (2014), which is derived from that of Hoekstra et al. (2012) but compensated for the fact that environmental flow requirements are not considered by using stricter threshold values for the different scarcity levels. A blue water scarcity level beyond 0.4 is classified as severe water scarcity and indicates that the blue WF exceeds $40 \%$ of the maximum sustainable blue WF. Levels in the ranges $0.3-0.4,0.2-0.3$ and $<0.2$ are classified as significant, moderate and low blue water scarcity, respectively.

The water pollution level is calculated as the ratio of the actual to the maximum sustainable grey WF (Hoekstra et al., 2011). The maximum sustainable grey WF, an indicator of the assimilation capacity for water pollution, equals the actual runoff, which is estimated as natural runoff minus the blue water consumed. The water pollution level thus measures the degree to which the waste assimilation capacity of blue water resources has been consumed. A water pollution level beyond hundred per cent means that the grey WF exceeds the sustainable level, thus ambient water quality standards are violated.

Finally, we review the sustainability of proposed solutions to Jordan's domestic water problems and external water dependency in literature, while involving the results from the analysis in this paper. We categorize the response options into five categories, which we use to position current water policy in Jordan. These categories are: (1) increasing water availability; (2) reducing water demand per unit of product; (3) reducing water demand by changing production and consumption patterns; (4) reducing risks related to the external water dependency; and (5) international assistance in taking in refugees.

\subsection{The Unsustainability of Water Consumption and Pollution in Jordan}

\subsubsection{The Water Footprint of Activities in Jordan}

The total WF in Jordan in the period $1996-2005$ was $1,446 \times 10^{6} \mathrm{~m}^{3} / \mathrm{y}(53 \%$ green; $31 \%$ blue; $16 \%$ grey) (Table 3-1). The productive use of green water in crop production and grazing systems accounts for the largest share in the total. Unsurprisingly, the largest blue WF is related to irrigated agriculture. Forty-five per cent of all water consumed (green plus blue) in crop production is blue, showing the high dependency of Jordanian agriculture on irrigation water. Blue water use is predominant in the Jordan Valley and the desert areas, while green water use is predominant in the Highlands (Talozi et al., 2015). 
Table 3-1. Water footprint of activities in Jordan (106 m³/y). Period: 1996-2005.

\begin{tabular}{|c|c|c|c|c|c|c|}
\hline Activity & $\begin{array}{l}\text { Green } \\
\text { water } \\
\text { footprint }^{\text {a }}\end{array}$ & $\begin{array}{l}\text { Blue } \\
\text { ground- } \\
\text { water } \\
\text { footprint }^{\text {b }}\end{array}$ & $\begin{array}{l}\text { Blue } \\
\text { surface } \\
\text { water } \\
\text { footprint }^{\text {b }}\end{array}$ & $\begin{array}{l}\text { Total } \\
\text { blue } \\
\text { water } \\
\text { foot- } \\
\text { printa,c }\end{array}$ & $\begin{array}{l}\text { Grey } \\
\text { water } \\
\text { footprint }^{a}\end{array}$ & $\begin{array}{l}\text { Total } \\
\text { water } \\
\text { footprint }\end{array}$ \\
\hline $\begin{array}{l}\text { Crop } \\
\text { production }\end{array}$ & 493 & 263 & 143 & 406 & 54.3 & 953 \\
\hline Grazing & 277 & & & & & 277 \\
\hline $\begin{array}{l}\text { Animal } \\
\text { water supply }\end{array}$ & & 1.4 & 9.9 & 11.3 & & 11.3 \\
\hline $\begin{array}{l}\text { Industrial } \\
\text { production }\end{array}$ & & 36.5 & 0.1 & 1.9 & 17.5 & 19.4 \\
\hline $\begin{array}{l}\text { Domestic } \\
\text { water supply }\end{array}$ & & 232 & 5.9 & 29.1 & 155 & 185 \\
\hline Total & 770 & 533 & 159 & 449 & 227 & 1,446 \\
\hline
\end{tabular}

a Calculated following Mekonnen \& Hoekstra (2011a) and Hoekstra \& Mekonnen (2012).

b Blue groundwater versus surface water footprint based on total blue water footprint and Alqadi \& Kumar (2014).

c Total blue water footprint is not equal to the sum of blue surface and groundwater footprint, because the blue groundwater footprints of industrial production and domestic water supply equal water abstraction instead of consumptive use only (Section 3.2).

Water consumption in the domestic and industrial sectors constitutes only about $7 \%$ of all blue water consumed in Jordan. The grey WF in these sectors is 5.6 times their blue water consumption, due to poor wastewater treatment. The WF figures relate to water consumption (net water abstraction) as opposed to water withdrawal (gross water abstraction) and therefore exclude return flows to the natural system. This explains the difference between the WF estimates in Table 3-1 and the figures on water use distribution over the different sectors reported by Hadadin et al. (2010) and Alqadi \& Kumar (2014) that indicate that around 35\% of all blue water is used in the industrial and domestic sectors. 
Table 3-2. Jordan's virtual water export (VWE) by product category $\left(10^{6} \mathrm{~m}^{3} / \mathrm{y}\right)$. Period: 1996-2005. Data based on Hoekstra \& Mekonnen (2012).

\begin{tabular}{|lccccc|}
\hline Product & Green & Blue & Grey & Total & \% of total \\
& VWE & VWE & VWE & VWE & \\
\hline Seed cotton & 270 & 149 & 53.8 & 473 & $45 \%$ \\
Animal products & 228 & 49.8 & 20.7 & 298 & $29 \%$ \\
Industrial products & 0.0 & 6.8 & 115 & 121 & $12 \%$ \\
Tomatoes & 5.9 & 11.9 & 0.0 & 17.7 & $2 \%$ \\
Wheat & 11.5 & 5.0 & 0.9 & 17.4 & $2 \%$ \\
Olives & 7.3 & 4.6 & 1.5 & 13.4 & $1 \%$ \\
Oil palm fruit & 8.3 & 0.0 & 0.3 & 8.6 & $1 \%$ \\
Artichokes & 3.8 & 2.9 & 0.0 & 6.7 & $1 \%$ \\
Papayas & 5.4 & 0.5 & 0.3 & 6.3 & $1 \%$ \\
Other crops & 51.7 & 26.3 & 5.4 & 83.4 & $8 \%$ \\
Total export & 592 & 256 & 198 & 1,046 & $100 \%$ \\
\hline
\end{tabular}

Part of the WF in Jordan is related to the production of crops and products for export. Total virtual water export from Jordan in the period 1996-2005 was around 1,046 $\times 10^{6}$ $\mathrm{m}^{3} / \mathrm{y}$ (Table 3-2). This is nearly three-quarters of the WF in Jordan (Table 3-1), but it also includes the virtual water related to the re-export of imported products. The largest virtual water export volumes are related to cotton-based products, animal products, and industrial products. However, since cotton is not grown in Jordan, the virtual water export associated with seed cotton is due to the re-export of imported cotton that has been processed in Jordan's textile industry. This means that the virtual water export from Jordanian water resources is mainly related to the export of animal and industrial products, whereby the latter is largely related to pollution (grey WF). Large volumes of Jordanian blue water resources (i.e., surface- and groundwater) are also exported in the form of tomatoes, wheat, and olives. 


\subsubsection{Blue Water Scarcity: Actual versus Maximum Sustainable Blue Water Footprint}

Precipitation over Jordan is highly variable in space and time (Toernros \& Menzel, 2014; Nortcliff et al., 2008; Mohsen, 2007). According to Mohsen (2007), precipitation varies from 6000 to 11,500 million $\mathrm{m}^{3} / \mathrm{y}$. The rainy season stretches from October/November to April/May, with $80 \%$ of precipitation occurring in the period from December to March and practically zero outside the rainy season (Toernros \& Menzel, 2014; Nortcliff et al., 2008; Al-Ansari et al., 2014). The northwest of Jordan is semi-arid, receiving 200-600 $\mathrm{mm} / \mathrm{y}$ of precipitation. Much of the eastern and southern part of the country, constituting about $80-90 \%$ of Jordan's surface area, is classified as arid and receives only 50-100 mm or less of precipitation each year (Van Aken et al., 2009; Hadadin et al., 2010; Mohsen, 2007; Nortcliff et al., 2008; Toernros \& Menzel, 2014). Groundwater availability is assumed to be equal to the "safe yield" from renewable groundwater resources (see Section 3.2), which is approximately $277 \times 10^{6} \mathrm{~m}^{3} / \mathrm{y}$ (Hadadin et al., 2010; Mohsen, 2007; Ministry of Water and Irrigation (MWI), 2009; El-Naqa \& Al-Shayeb, 2009; Ministry of Water and Irrigation (MWI), 2013). We estimate Jordan's renewable surface water resources in the period $1996-2005$ at $373 \times 10^{6} \mathrm{~m}^{3} / \mathrm{y}$ by taking the sum of treaty allocations $\left(220 \times 10^{6} \mathrm{~m}^{3} / \mathrm{y}\right)$ and flow from wadis in the Jordan River Valley $\left(153 \times 10^{6} \mathrm{~m}^{3} / \mathrm{y}\right)$ in the year 2000 according to Hadadin et al. (2010). Total renewable water resources (surface- and groundwater) are therefore estimated in this study at $650 \times 10^{6} \mathrm{~m}^{3} / \mathrm{y}$. This is slightly lower than the $671 \times 10^{6} \mathrm{~m}^{3} / \mathrm{y}$ of renewable blue water in 2000 as estimated by Van Aken et al. (2009) and slightly higher than the sum of developed surface water resources, flow secured by the peace treaty with Israel, and safe yield from groundwater as reported for the year 2007 in Jordan's national water strategy (Ministry of Water and Irrigation (MWI), 2009), namely $620 \times 10^{6} \mathrm{~m}^{3} / \mathrm{y}$. Due to Jordan's high dependency on water from upstream and neighbouring countries, total blue water availability in Jordan is not purely natural runoff. Rather, it is actual inflow into Jordan from upstream countries (natural inflow minus what has been consumed through upstream WFs) plus naturally generated runoff from precipitation over Jordan.

When comparing the blue WF to blue water availability, we find that, overall, Jordan is severely water scarce (water scarcity ratio $>0.4$ ), and that groundwater is overexploited (water scarcity ratio $>1$ ) (Table 3-3). The groundwater scarcity index indicates that the blue ground-WF in Jordan is nearly double the groundwater availability. Other quantitative estimates of the country-average ratio of groundwater withdrawal over safe yield range from 1.6 (El-Naqa \& Al-Shayeb, 2009) to 1.9 (Mohsen, 2007; Alqadi \& Kumar, 2014). 
Table 3-3. Blue water scarcity in Jordan regarding total runoff and groundwater only.

\begin{tabular}{|c|c|c|c|c|}
\hline Water resource & $\begin{array}{l}\text { Water } \\
\text { footprint } \\
\left(10^{6} \mathrm{~m}^{3} / \mathrm{y}\right)\end{array}$ & $\begin{array}{l}\text { Water } \\
\text { availability } \\
\left(10^{6} \mathrm{~m}^{3} / \mathrm{y}\right)\end{array}$ & $\begin{array}{l}\text { Water scarcitya } \\
(-)\end{array}$ & $\begin{array}{l}\text { Water scarcity } \\
\text { level }\end{array}$ \\
\hline $\begin{array}{l}\text { Total (surface and } \\
\text { groundwater) }\end{array}$ & 449 & 650 & 0.69 & Severe \\
\hline Groundwater & 533 & 277 & 1.92 & Overexploited \\
\hline
\end{tabular}

a Calculated in this study.

b Surface water availability from Hadadin et al. (2010); Groundwater availability from as the safe yield reported by various studies (Hadadin et al., 2010; Mohsen, 2007; Ministry of Water and Irrigation (MWI), 2009; El-Naqa \& Al-Shayeb, 2009; Ministry of Water and Irrigation (MWI), 2013).

Although other studies have also described water scarcity in Jordan as severe, our estimate is even more alarming, since we have looked at water consumption (excluding return flows) rather than withdrawals.

\subsubsection{Water Pollution Level: Actual versus Maximum Sustainable Grey Water Footprint}

Although the grey WFs of the various sectors as calculated relate to different forms of pollution (the grey WFs of the industrial and domestic sectors relate to the aggregate of pollutants, while the grey WF of crop production relates to nitrate-nitrogen only), we find it appropriate, as a rough estimate, to compare the total grey WF in Jordan with actual runoff. The latter is calculated as the total blue water availability in Jordan minus the total blue WF in Jordan, thus representing runoff after depletion by human consumption. This is the volume of water that is available to dilute pollutants and is termed "waste assimilation capacity" (Hoekstra et al., 2011). The water pollution level, the ratio of the actual to the maximum sustainable grey WF, is found to be 1.13 (Table 34). This indicates that the grey WF in Jordan exceeds waste assimilation capacity, meaning that ambient water quality standards are violated, which confirms the widelyvoiced pollution of Jordan's water resources (Jaber \& Mohsen, 2001; Scott et al., 2003; Mohsen, 2007; Venot \& Molle, 2008; El-Naqa \& Al-Shayeb, 2009; Hadadin et al., 2010; Alqadi \& Kumar, 2014, 2013). 
Table 3-4. Water pollution level in Jordan.

\begin{tabular}{|lr|}
\hline Water footprint and pollution level & Value \\
\hline Total grey water footprint & $227 \times 10^{6} \mathrm{~m}^{3} / \mathrm{y}$ \\
Maximum sustainable grey water footprint & $201 \times 10^{6} \mathrm{~m}^{3} / \mathrm{y}$ \\
Water pollution level & 1.13 \\
\hline
\end{tabular}

\subsection{Jordan's Dependency on Foreign Water Resources}

With respect to transboundary water resources, total treaty allocations to Jordan (from the Jordan and Yarmouk rivers and various springs) around the year 2000 sum up to $220 \times 10^{6} \mathrm{~m}^{3} / \mathrm{y}$ (Hadadin et al., 2010). Comparing this with renewable blue water availability in Jordan around that time $\left(650 \times 10^{6} \mathrm{~m}^{3} / \mathrm{y}\right)$, we find that the ratio of external to total water resources of Jordan is $34 \%$. In other words, Jordan is dependent on upstream and neighbouring countries for one-third of its annual renewable water resources.

Jordan's virtual water import dependency is even larger. Of all the water consumption associated with the production of the products and commodities Jordanians consume, $86 \%$ takes place outside Jordan's borders and is spread all over the world (Figure 3-3). The total WF of Jordan's consumption in the period 1996-2005 is estimated at $8,316 \times 10^{6}$ $\mathrm{m}^{3} / \mathrm{y}$, of which $6,712 \times 10^{6} \mathrm{~m}^{3} / \mathrm{y}$ is virtual water import (Table 3-5). With virtual water import being more than six times larger than virtual water export (Table 3-2), Jordan is a large net virtual water importer. Jordan obtained a national water savings of $7,113 \times 10^{6} \mathrm{~m}^{3} / \mathrm{y}$ through trade in the period 1996-2005. This is the volume of water that would have been required had Jordan produced all imported commodities itself. 


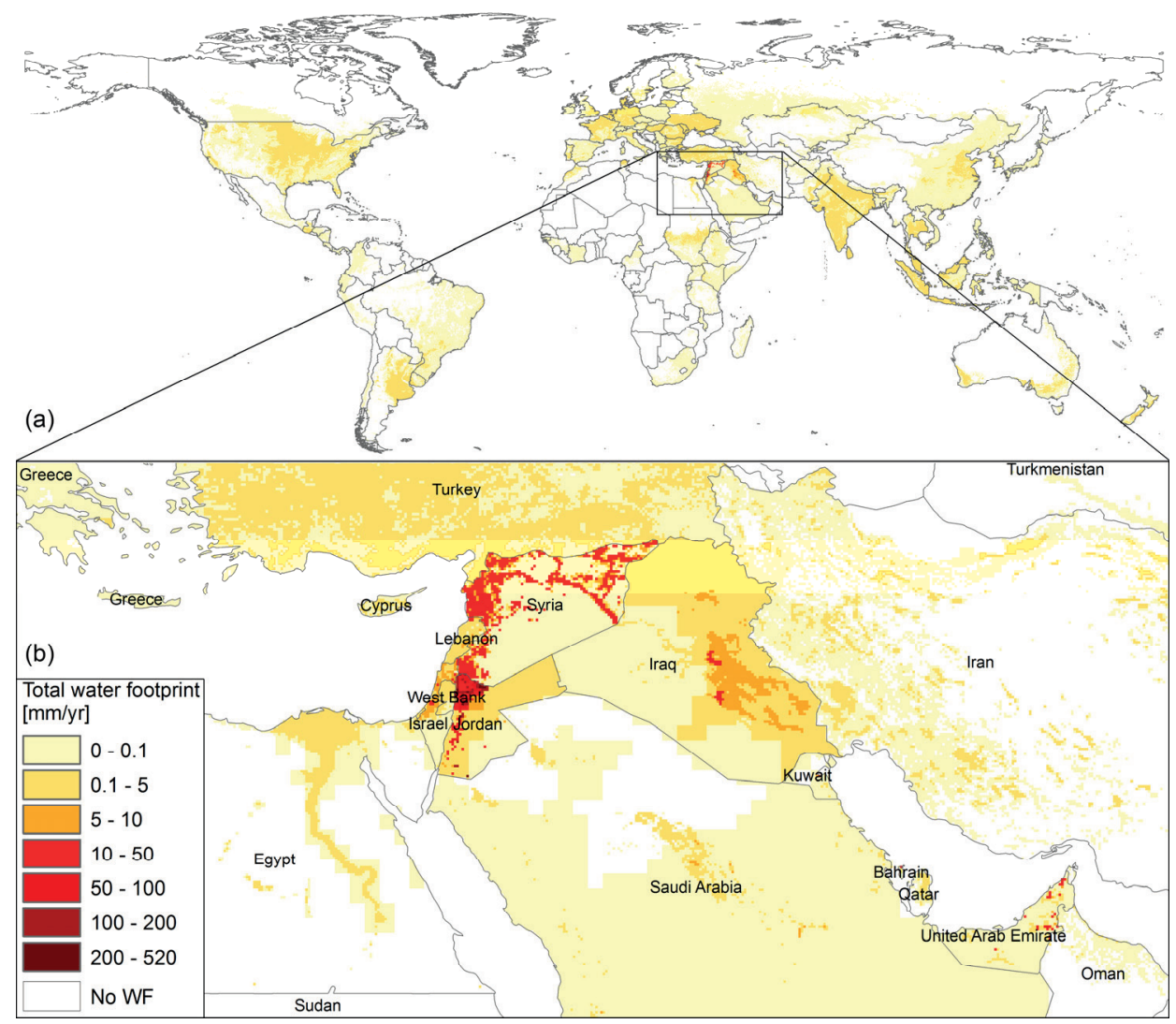

Figure 3-3. The global water footprint of Jordan's consumption (a) and an enlarged view of the Middle East (b). Both follow the legend depicted in (b). Period: 1996-2005. Data based on Hoekstra \& Mekonnen (2012).

The largest volumes of imported virtual water in the study period are associated with import of: wheat from the USA; barley from Syria and Iraq; maize, soybeans, and wheat from Argentina; animal products and soybeans from India; oil palm from Malaysia and Indonesia; and cotton from China (Table 3-6). However, it should be noted that the import pattern has changed since then. Data from FAO (2015b) shows that since 2004/2005 barley imports from Syria and Iraq have ceased and instead have mainly come from Ukraine, Germany, Russia, and, more recently, Romania. Also since 2004/2005, Jordan mainly imports wheat from Russia, Ukraine, and Syria, with only relatively small amounts from USA and practically zero from Argentina (FAO, 2015b). Nevertheless, Jordan's dependency on virtual water imports remains evident. 
Table 3-5. Jordan's virtual water import (VWI) by major product $\left(10^{6} \mathrm{~m}^{3} / \mathrm{y}\right)$. Period: $1996-$ 2005. Data based on Hoekstra \& Mekonnen (2012).

\begin{tabular}{|c|c|c|c|c|c|}
\hline Product & $\begin{array}{l}\text { Green } \\
\text { VWI }\end{array}$ & $\begin{array}{l}\text { Blue } \\
\text { VWI }\end{array}$ & $\begin{array}{l}\text { Grey } \\
\text { VWI }\end{array}$ & $\begin{array}{l}\text { Total } \\
\text { VWI }\end{array}$ & $\%$ of total \\
\hline Barley & 1,067 & 217 & 155 & 1,439 & $21 \%$ \\
\hline Wheat & 937 & 63 & 102 & 1,102 & $16 \%$ \\
\hline Animal products & 524 & 66 & 17 & 607 & $9 \%$ \\
\hline Oil palm fruit & 524 & 0 & 28 & 551 & $8 \%$ \\
\hline Cotton & 221 & 169 & 107 & 497 & $7 \%$ \\
\hline Soybeans & 454 & 14 & 9 & 477 & $7 \%$ \\
\hline Maize & 367 & 20 & 57 & 444 & $7 \%$ \\
\hline Sugar cane & 212 & 70 & 17 & 300 & $4 \%$ \\
\hline Other crops & 626 & 259 & 67 & 952 & $14 \%$ \\
\hline $\begin{array}{l}\text { Industrial } \\
\text { products }\end{array}$ & 0 & 23 & 319 & 342 & $5 \%$ \\
\hline Total import & 4,933 & 902 & 878 & 6,712 & $100 \%$ \\
\hline
\end{tabular}

The largest component in the total WF of the average Jordanian consumer relates to the consumption of animal products such as meat, hides and skins, and milk (Figure 3-4). This WF is largely located outside Jordan. For example, imports of animal products associated with large WFs came from India and Australia. Higher standards of living in Jordan (Ammary, 2007) are likely associated with an increased share of animal products in the average diet and hence an increased WF of consumption. 
Table 3-6. Jordan's virtual water import (VWI) per major trade partner $\left(10^{6} \mathrm{~m}^{3} / \mathrm{y}\right)$. Period: 1996-2005. Data based on Hoekstra \& Mekonnen (2012).

\begin{tabular}{|c|c|c|c|c|c|}
\hline Country & $\begin{array}{l}\text { Green } \\
\text { VWI }\end{array}$ & $\begin{array}{l}\text { Blue } \\
\text { VWI }\end{array}$ & $\begin{array}{l}\text { Grey } \\
\text { VWI }\end{array}$ & $\begin{array}{l}\text { Total } \\
\text { VWI }\end{array}$ & Major Products \\
\hline USA & 697 & 88 & 123 & 908 & Wheat $-66 \%$, maize $-16 \%$, rice $-8 \%$ \\
\hline Syria & 626 & 92 & 122 & 840 & Barley $-78 \%$, animal products $-4 \%$ \\
\hline Argentina & 641 & 11 & 31 & 683 & $\begin{array}{l}\text { Wheat }-25 \% \text {, maize- } 38 \% \text {, soybean- } \\
35 \%\end{array}$ \\
\hline India & 434 & 35 & 29 & 498 & $\begin{array}{l}\text { Animal products }-40 \% \text {, soybean- } \\
34 \% \text {, coffee- } 7 \% \text {, wheat }-6 \% \text {, cotton- } \\
4 \%\end{array}$ \\
\hline Iraq & 172 & 222 & 156 & 550 & $\begin{array}{l}\text { Barley- } 69 \% \text {, industrial products- } \\
29 \%\end{array}$ \\
\hline Malaysia & 319 & 0.5 & 14 & 333 & Oil palm-97\% \\
\hline Indonesia & 238 & 0.1 & 17 & 255 & Oil palm-88\% \\
\hline China & 133 & 22 & 83 & 239 & $\begin{array}{l}\text { Cotton- } 71 \% \text {, industrial products- } \\
14 \% \text {, animal products- } 6 \%\end{array}$ \\
\hline Turkey & 172 & 21 & 25 & 218 & $\begin{array}{l}\text { Wheat }-41 \% \text {, barley- } 29 \% \text {, } \\
\text { cheakpeas- } 13 \% \text {, cotton- } 7 \%\end{array}$ \\
\hline Ukraine & 173 & 4 & 30 & 208 & $\begin{array}{l}\text { Barley- } 60 \% \text {, sunflower seed- } 16 \% \text {, } \\
\text { industrial products- } 14 \% \text {, wheat- } \\
9 \% \text {, }\end{array}$ \\
\hline Australia & 93 & 41 & 3 & 138 & $\begin{array}{l}\text { Animal products }-53 \% \text {, rice }-32 \% \text {, } \\
\text { barley- } 12 \%\end{array}$ \\
\hline
\end{tabular}




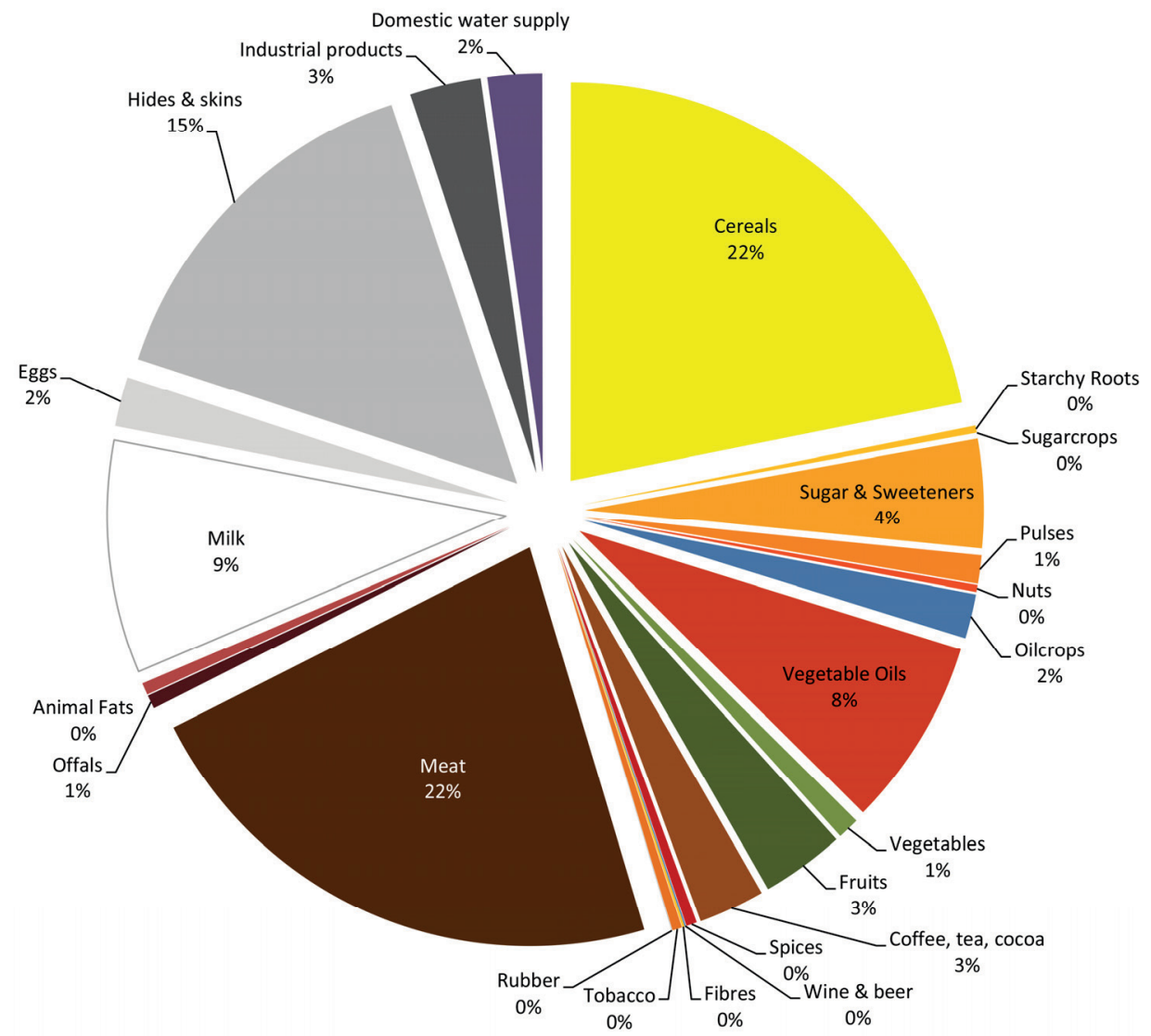

Figure 3-4. The average water footprint of a consumer in Jordan. Period: 1996-2005. Data based on Hoekstra \& Mekonnen (2012).

\subsection{Options to Respond to Jordan's Domestic Water Problems and External Water Dependency}

We review various solutions that have been discussed in the past to greater or lesser extent to address Jordan's domestic water problems and external water dependency. We categorize the various response options into five categories, which are subsequently addressed in the following sections: (1) increasing water availability; (2) reducing water demand per unit of product; (3) reducing water demand by changing production and consumption patterns; (4) reducing risks related to the external water dependency; and (5) international assistance in taking in refugees. Lastly, we reflect upon the position of current water policy in Jordan with respect to the first three categories. 


\subsubsection{Increasing Water Availability}

Dams for Inter-Seasonal Water Storage

Between 1950 and 2008, twenty-eight dams have been built in Jordan, with a total storage capacity of $368 \times 10^{6} \mathrm{~m}^{3}$ (Al-Ansari et al., 2014). The newest and largest is the AlWehdah Dam on the Yarmouk River with a storage capacity of $110 \times 10^{6} \mathrm{~m}^{3}$ (Ministry of Water and Irrigation (MWI), 2013), although it only received $41 \times 10^{6} \mathrm{~m}^{3}$ from 2006 to 2010 and its utility is reduced due to water quality issues (Al-Taani, 2013). Constructing more dams does not seem to be the way to increased water availability and reduced water scarcity in Jordan. A lot of water is namely lost by evaporation from surface water reservoirs (Mekonnen \& Hoekstra, 2012a; Schyns \& Hoekstra, 2014), especially in arid regions such as Jordan. There comes a point where inter-seasonal storage and release of water during low flow conditions does no longer outweigh the water loss by evaporation (Goldsmith \& Hildyard, 1984).

\section{Disi Water Conveyance Project}

The recently realized Disi Water Conveyance Project (Namrouqa, 2013), supplies the greater Amman region from the fossil Disi aquifer, mainly to prevent public water supply shortages (Aulong et al., 2009; Hadadin et al., 2010; Scott et al., 2003). This is however a short-term, unsustainable solution. The annually abstracted volume from the Disi aquifer is about $100 \times 10^{6} \mathrm{~m}^{3} / \mathrm{y}$ (Ministry of Water and Irrigation (MWI), 2012; Salameh et al., 2014), which can be regarded as a blue fossil ground-WF since there is no return flow from this abstracted volume to the aquifer. It has been estimated that the Disi aquifer can be exploited at a rate of $125 \times 10^{6} \mathrm{~m}^{3} / \mathrm{y}$ for 50 years (Mohsen, 2007; World Bank, 1997). This means that if current abstraction rates continue in the future, the Disi aquifer will be significantly depleted in about 50 years from now. The already visible consequences of mining the Disi aquifer in the past are discussed by Salameh et al. (2014). Besides, the Disi Water Conveyance Project has a big energy footprint due to the distance and altitude difference that needs to be bridged (Talozi et al., 2015). Furthermore, the quality of the Disi water has been under discussion, since it has been shown that the Disi aquifer contains high amounts of radioactive isotopes (Vengosh et al., 2009). It would be wise to cap the fossil ground-WF in Jordan to zero and use the water from non-renewable resources only when it is urgently needed; in low amounts and at low frequencies. 


\section{Desalination}

According to several authors (Mohsen, 2007; Hadadin et al., 2010; Alqadi \& Kumar, 2014; Salameh et al., 2014), the most promising long-term solution to the water problems in Jordan is desalination. The main project regarding desalination is the Red Sea Dead Sea Canal project. Early in 2015, Jordan and Israel signed a 'green-light' agreement for this project (Al-Khalidi, 2015). Jordan's national water strategy projects for 2022 an additional amount of $510 \times 10^{6} \mathrm{~m}^{3} / \mathrm{y}$ desalted water compared to 2007 , mainly to be realised by the Red Sea Dead Sea Canal project (Ministry of Water and Irrigation (MWI), 2009). Besides desalination, a major goal of the project is to restore the water level of the Dead Sea at around 400 meters below sea level with imported water from the Red Sea (Beyth, 2007). The Red Sea Dead Sea Canal project, which also aims to supply Israel and Palestine, should also bring increased political stability to the region by improved regional water security (Beyth, 2007). According to estimates by Al-Omari et al. (2013; 2015), the additional freshwater supply from the Red Sea Dead Sea Canal can reduce the domestic and irrigation water deficit in the Jordan valley down to zero, even under increased water demand and reduced water availability in their climate change scenario.

Increasing Jordan's water availability by desalination of salt or brackish seems an attractive option, especially to ensure public water supply. However, this is under the provision that the required energy for the very energy-intensive process of desalination is driven by sustainable solar and/or wind power. The Red Sea Dead Sea Canal requires additional energy for intake of the water from the Gulf of Aqaba and transport through the canal and to the public water supply stations. Part of the energy is generated in the project itself by hydro turbines driven by the large elevation differences, but a significant energy demand remains (Beyth, 2007). Meeting this demand with fossil energy is of course not sustainable. Moreover, it would also make Jordan increasingly dependent on foreign energy resources, since Jordan is poor on oil and gas (U.S. Energy Information Administration (EIA), 2014). Most recent data for 2011 shows that Jordan already imports 96\% of the energy it uses (World Bank, 2015). Jordan's energy-dependency is thus even larger than its dependency on foreign water resources (86\%; Section 3.4).

Water Harvesting and Productive Use of Precipitation

Various options have been proposed to make better use of the precipitation that falls over Jordan: (a) building micro-dams along major water courses to store flood water during winter (Mohsen, 2007; Hadadin et al., 2010); (b) improved soil management to increase soil moisture storage in rain-fed agriculture (leading to less unproductive 
evaporation and higher yields) (Hadadin et al., 2010); (c) productively using the limited rainfall over the desert areas by growing more drought-tolerant crops (Talozi et al., 2015); and (d) rainwater harvesting in urban areas for domestic purposes that do not require drinking water quality (Hadadin et al., 2010; Jaber \& Mohsen, 2001; Abdulla \& Al-Shareef, 2009). Regarding the latter, Abdulla \& Al-Shareef (2009) estimate that a maximum of $15.5 \times 10^{6} \mathrm{~m}^{3} / \mathrm{y}$ of rainwater can be harvested from the roofs of Jordanian residential buildings, that is, if all rain on all surfaces is collected. For drinking purposes, this water would require proper treatment (Abdulla \& Al-Shareef, 2009). All these options seem worthwhile investigating and implementing. Probably, they are able to reduce the frequency and size of domestic and agricultural water shortages, when supply temporarily falls short of demand. E.g., think of weeks in which potable water supply through the official network is cut, in which stored urban rainwater from the previous week can partially alleviate the shortage for some household purposes. Regarding agriculture, one could think of a short-term dry spell experienced at a particular site - which normally severely limits crop yields - but which the crop can survive through better soil management, because previous precipitation events sufficiently recharged the soil moisture. However, their potential seems insufficient to significantly alleviate water scarcity in Jordan, which is characterized by an imbalance between water availability and demand on a larger spatial and temporal scale (Schyns et al., 2015).

\section{Treatment and Reuse of Wastewater}

An important track followed by Jordan is the treatment and reuse of wastewater, mainly in agriculture (Ministry of Water and Irrigation (MWI), 2009; Ammary, 2007). The percentage of total generated wastewater in Jordan that was actually reused increased from $30 \%$ to $38 \%$ in the period 2004-2007 (Alfarra et al., 2011). Treated domestic and industrial wastewater supplies $12 \%$ of Jordan's irrigation water (Sowers et al., 2011) and the effect of that on soils and crops remains a topic of study (Batarseh et al., 2011). Potential future uses of treated wastewater are groundwater recharge and industrial cooling (Ammary, 2007).

Obviously, implementation of proper wastewater treatment will improve the water quality of Jordan's surface- and groundwater resources. However, reuse of treated wastewater is not always possible and limited by the presence of certain substances (Sowers et al., 2011). There are also several challenges to overcome negative perceptions towards the reuse of treated wastewater, which may be due to cultural and religious concerns (Carr \& Potter, 2013; Carr et al., 2011). Furthermore, one should avoid the 
pitfall of viewing wastewater as a new freshwater source that comes in addition to other water sources such as ground- and surface water and desalinated water (Hoekstra et al., 2011). Wastewater originates from one of those other sources, so one cannot increase water availability through reuse.

\subsubsection{Reducing Water Demand per Unit of Product}

Rationalization of Irrigation Water Use

Irrigated agriculture has the largest blue WF in Jordan (Table 3-1). In theory, irrigation water use can be reduced by increasing the price of irrigation water (Van Aken et al., 2009; Ramirez et al., 2011; Doppler et al., 2002; Al-Karablieh et al., 2012), improved irrigation systems (Molle et al., 2008; Hadadin et al., 2010; Comair et al., 2013; Shatanawi et al., 2005) and training farmers in irrigation practices (Venot \& Molle, 2008; Ramirez et al., 2011). Furthermore, reinforcing private ownership of wells may be an option, since well-owners have shown to use irrigation water and groundwater resources in a more sustainable way than well-leasers (Ramirez et al., 2011).

In practice, the effectiveness of these options is limited though. Molle et al. (2008) argue that the scope for pricing mechanisms to improve irrigation and economic efficiency in the Jordan Valley is limited. Substantial water price increases are expected to have an effect, but then farmers should be offered alternatives (e.g. less water-intensive crops or possibilities to exit agriculture) and positive incentives that lower capital and risk constraints for farmers should be co-implemented (Molle et al., 2008). According to Van Aken et al. (2009), improving irrigation efficiencies will merely reduce return flows (resulting from over-applied water) to the underlying aquifers and hence do not lead to actual water savings from a catchment point of view. Furthermore, since a great deal of the irrigation area in Jordan has already been converted to advanced irrigation systems supplied from a pressurized pipe network (FAO, 2014; Molle et al., 2008; Shatanawi et al., 2005; Haddadin, 2009), the remaining potential of increasing irrigation efficiency is probably limited. However, there is room for water savings by better design and maintenance of the drip irrigation systems and better irrigation scheduling (Shatanawi et al., 2005; Molle et al., 2008).

\section{Reduce Green and Blue Water Footprints of Crops: Benchmarks}

Introducing crop-specific benchmarks is a way to make sure that the green and blue water consumption to produce a tonne of a certain crop in Jordan remains below reasonable levels (Hoekstra, 2014, 2013). These benchmarks can for example be developed by looking at the best $\mathrm{X} \%$ performing farmers in Jordan regarding WFs, or in 
neighbouring countries with comparable climate and soil conditions. This can set a target for other farmers, who can reduce their water consumption per unit of crop by adopting advanced irrigation techniques with smart and efficient irrigation scheduling and improving soil and crop management (affecting both green and blue water use), all to avoid unproductive evaporation and increase yields. The challenge will be to provide sufficient stimuli and capital for farmers to achieve the benchmarks (or penalties for not achieving them).

Although crop production has the largest WF and hence reduction of the WF per unit of crop will have the largest overall effect on reducing the WF in Jordan, benchmarks can also be developed for other water-consuming sectors in Jordan, for example the large animal industry in the country. It should be noted however that with options to reduce the water demand per unit of product, the rebound effect lures. This refers to the situation in which the saved water is used for extra production, thus (partially) offsetting the environmental gains of the efficiency improvement (Hoekstra, 2014).

\section{Reduce Grey Water Footprints: Prevent and Treat}

To reduce grey WFs, water pollution should in the first place be prevented as much as possible and unavoidable waste streams should be properly treated. Educating farmers in the use of fertilizers could reduce agricultural pollution caused by over- and misuse of fertilizers. Also here, benchmarks could serve as a target for industries and farmers to minimize their grey WFs. By properly treating unavoidable wastewater streams, much of the current pressure that pollution puts on blue water resources can be relieved. Therefore, Jordan should further invest in wastewater treatment plants.

\section{Rehabilitation of Public Water Supply Network}

Water savings are expected by rehabilitation of the potable water distribution network and subsequent proper maintenance of these systems, especially in the capital Amman (Abu-Shams \& Rabadi, 2003; Scott et al., 2003; Aulong et al., 2009; Van Aken et al., 2009; Comair et al., 2013). Currently, much water is lost in these networks by leakages (30-50\% (Van Aken et al., 2009)). However, from a catchment perspective this water that leaks from underground pipes is not considered a loss, because it will probably return to the groundwater and surface water rather than evaporate. In other words, this option will help in reducing public water supply shortages, but does not reduce water scarcity in Jordan from an environmental point of view. 


\subsubsection{Reducing Water Demand by Changing Production and Consumption Patterns}

Maximum Sustainable Water Footprints: Caps and Permits

To prevent resource overconsumption, a WF cap that equals the maximum sustainable WF in a river basin or aquifer and a system of WF permits could be established (Hoekstra \& Wiedmann, 2014; Hoekstra, 2014). This is especially urgent for Jordan's groundwater resources. We have estimated that the ground-WF in Jordan is nearly double the groundwater availability (Section 3.3.2). All sectors in Jordan heavily rely on groundwater (Table 3-1; Alqadi \& Kumar (2014)). To prevent this vital resource from drying up, Jordan should protect its groundwater from overexploitation by making sure that the ground-WFs remain below maximum sustainable levels. For each aquifer, the Ministry of Water and Irrigation and the Water Authority of Jordan could issue groundWF permits amongst the water consumers. The sum of these permits shall not exceed the groundwater availability for each aquifer, defined as the groundwater recharge minus the fraction of natural groundwater outflow required to sustain environmental flow requirements in the river fed by the aquifer (Hoekstra et al., 2011). It would be wise to formally establish the groundwater availability of each aquifer as a ground-WF cap, which represents the maximum sustainable ground-WF for the aquifer. Ideally, such ground-WF caps are reconsidered on a yearly basis (Hoekstra, 2013), to account for the high inter-annual variability in rainfall and groundwater recharge in Jordan.

Although in the past efforts have been made to limit groundwater abstractions, limits have not been respected and too many abstraction permits have been issued (Van Aken et al., 2009; Venot \& Molle, 2008; Molle et al., 2008). Clearly, it will be a challenge to establish ground-WF caps and proper issuing and enforcement of ground-WF permits while managing the social and economic consequences of reducing groundwater consumption. Promising additional policies include regulations on the number of new wells being drilled (Alqadi \& Kumar, 2014) and selective closure of wells by restricted permitting and buyouts (Venot \& Molle, 2008). Moreover, increases in the price of energy (electricity and fuels) could give farmers an incentive to reduce groundwater (over)pumping (Scott et al., 2003).

A cap on the surface WF in the Jordan River Basin and its sub-catchments would also benefit the environment by (partially) restoring historical runoff and flow into the Dead Sea. However, because the basin is shared by five countries in a politically tense region, this remains fairly far-fetched for the near future. Nevertheless, when first focusing on capping ground-WFs, one should be aware of, and try to manage, the risk of increased 
surface-WFs as a result of that. The opposite happened when surface water diversions were capped in the Murray-Darling river basin (Hoekstra, 2013).

\section{Produce High Value-Added Products and Crops: Allocation Efficiency}

Maximum sustainable WFs dictate how much water can be used in total (in a specific basin or aquifer). Optimal use of the sustainably available water can be achieved by changes in the production pattern. It has been voiced that Jordan should promote a shift from water-intensive low value added crops to less water-intensive and high value added crops (Scott et al., 2003; Van Aken et al., 2009; Mohsen, 2007; Al-Weshah, 2000; Abu-Sharar et al., 2012) or completely towards other sectors than agriculture (Scott et al., 2003; Mohsen, 2007).

Wise water allocation in Jordan should focus on meeting domestic water demand and production of high value added products and crops with relatively low WFs for export. The income generated by export can then be used to import water-intensive commodities (mainly agricultural products) required by the Jordan population. This will indeed be socially difficult to obtain, although Jordan is not so dependent on agriculture as one might think (Mohsen, 2007), and make Jordan even more dependent on foreign water resources than it already is. However, the latter is practically unavoidable for countries poor in natural resources such as Jordan.

Politics is perhaps the biggest reason that water reallocation between crops and sectors has not been successful so far. As elaborately discussed by Van Aken et al. (2009) and Zeitoun et al. (2012), there are influential tribes and political elites who exert powerful opposition against such measures. Furthermore, pricing mechanisms do not affect a large part of the farms where water-intensive crops are grown, which are owned by absentee owners who are interested in prestige or leisure rather than farm returns (Van Aken et al., 2009).

\section{Change Consumption Patterns}

A further step in water demand management is to influence consumption patterns that ultimately drive the demand for water and thus the domestic water scarcity and external water dependency. Several authors have noted that programs to educate water users and raise awareness among the public could help in reducing water use (Venot \& Molle, 2008; Hadadin et al., 2010; Mohsen, 2007; Al-Ansari et al., 2014). Specifically, such campaigns should focus on the WF associated with the products Jordanians consume and how changes in their consumption pattern could significantly lower the pressure on 
water resources. This would be far more effective than focusing on water conservation techniques in the household, since the WF of an average consumer in Jordan relates for only $2 \%$ to water consumption in and around the house (Figure $3-4$ ). On the other hand, nearly half of the WF of the average Jordanian consumer is associated with the consumption of animal products (of which $22 \%$ meat) and this share is likely to increase due to higher standards of living. Therefore, effective campaigns to stimulate reduced meat consumption, such as meat-free days, seem to be the way to a smaller WF in Jordan (and elsewhere). Also product labels, physical or digital, that inform the consumer about the WF of a product and the degree of water scarcity in the catchment where it was produced and/or provide a simple 'yes or no' advice based on certain sustainability criteria (Hoekstra, 2013), would raise awareness and ultimately influence consumer choices for the better (reduced environmental impact).

\subsubsection{Reducing Risks Related to the External Water Dependency}

It has long been recognized that Jordan is strongly water-dependent on other countries, because the country is a large net virtual water importer (Haddadin, 2003; Chapagain \& Hoekstra, 2003; Hoekstra \& Hung, 2005; Hoekstra \& Chapagain, 2008; Mourad et al., 2010; Hadadin et al., 2010; Allan, 2002; Abu-Sharar et al., 2012). Externalizing its consumption-related WF is an important mechanism for Jordan to reduce water demand within its borders.

The previously discussed solutions potentially enable sustainable use of Jordan's domestic water resources, accepting that the country remains heavily dependent on external water resources. Jordan is by far too poor in water resources to be self-sufficient or even nearly self-sufficient. Hence, Jordan's already large external water dependency

will unavoidably continue in the future. There are two important strategies for Jordan to mitigate the associated risks.

By externalizing its WF Jordan creates additional pressure on foreign water resources. Importing virtual water from regions that are under a degree of water scarcity similar or worse than Jordan is not sustainable and carries the risk of unreliable import flows caused by water limitations elsewhere (e.g. failure of yields due to drought). Major trade partners of Jordan that have river basins facing severe water scarcity during several months of the year are for example Australia, China, India, Turkey and the USA (Hoekstra et al., 2012). An important strategy for Jordan is therefore to aim at importing water-intensive commodities from nations that are not under a high degree of water scarcity, e.g. from countries in Northern Europe, South America, Central Africa, or 
Canada (Gerten et al., 2011; Hoekstra et al., 2012). This is a growing challenge, since water scarcity is becoming increasingly important, not only blue but also green water scarcity (Schyns et al., 2015). When an increasing number of regions in the world face water limitations to production, externalizing water consumption to other, less water scarce, nations will become more difficult.

As a second strategy, Jordan can reduce the risk of import dependency by diversifying its imports over various trade partners. Looking at Jordan's external WF in the period 1996-2005 and food imports since (Section 3.4), we already see a shift in Jordan's import partners away from Syria and Iraq, most probably inevitable due to the unstable situations in these countries.

Moreover, as noted in the previous section, to be able to maintain a high virtual water import dependency economically, Jordan should generate sufficient income to finance imports. Therefore it should use its domestic resources to produce high value added low water consuming products for export.

In contrast to our view, Alqadi \& Kumar (2014) state that further reliance on virtual water import is not the way to go for Jordan and that desalination is the only means to replace current virtual water imports. However, it is unthinkable that Jordan domestically produces the majority of the commodities it currently imports. Jordan's national water saving by trade is huge, being in the order of annual precipitation over Jordan and more than 10 times larger than renewable blue water resources. In other words, even in the hypothetical situation that all rainfall over Jordan would be used productively to make the commodities consumed by the people in Jordan, this would barely suffice. To put it differently, nearly 14 times the projected volume of desalted water in $2022\left(520 \times 10^{6} \mathrm{~m}^{3} / \mathrm{y}\right.$ (Ministry of Water and Irrigation (MWI), 2009)) would be required to replace the water Jordan saved by virtual water imports. Notwithstanding the limitations of available arable land in Jordan to becoming more self-sufficient.

Reduced risk from Jordan's dependency on transboundary rivers and aquifers will need to come from international cooperation towards improved regional water security. It shall be clear that this is a major challenge considering the history of the region (Haddadin, 2011), recent conflicts in the region (Gleick, 2014; de Chatel, 2014) and biased knowledge production (Messerschmid \& Selby, 2015).

\subsubsection{International Assistance in Taking in Refugees}

Jordan has serious problems to secure its domestic water supply and has to cope with large refugee influxes (Scott et al., 2003; Mohsen, 2007; Hadadin et al., 2010; Alqadi \& 
Kumar, 2011; Talozi et al., 2015). Because Jordan's water resources are currently insufficient to support the already large and rapidly increasing population in a sustainable manner, the international community should assist Jordan in taking in refugees.

Alongside with Lebanon, Turkey, Iraq and Egypt, Jordan is in the top five host countries of Syrian refugees, together hosting roughly 95\% of the Syrian refugees by 2014 (Amnesty International, 2014). A year later, with the Islamic State having taken over large parts of Syria and Iraq and the upheaval of the Israeli-Palestinian conflict in the summer of 2014, the numbers of refugees in Jordan has expanded even more (Figure 32). As Jordan and other first-host countries do not have the capacity to cope with the sudden large population growth, this could eventually lead to economic and social instability in these countries (Achilli, 2015).

Financial humanitarian aid is mainly coming from the European Union (EU) (Amnesty International, 2014; Trombetta, 2014). However, only about $4 \%$ of all Syrian refugees sought asylum in the EU (United Nations High Commissioner for Refugees (UNHCR), 2014) and they are predominantly taken in by Germany and Sweden (Amnesty International, 2014). Furthermore, the Gulf Cooperation Council (GCC) could potentially provide more assistance. According to Amnesty International (2014), the countries of the GCC (Bahrain, Qatar, Saudi Arabia, Oman, Kuwait and the United Arab Emirates) have contributed zero resettlement places for Syrian refugees.

\subsubsection{Positioning Current Water Policy in Jordan}

With respect to the first three response categories discussed above (Sections 3.5.1-3.5.3), current water policy in Jordan is mainly focused on the first category of response: increasing water availability (Alqadi \& Kumar, 2014; Zeitoun et al., 2012). To a lesser extent, policy is directed at reducing water demand per unit of product by improving efficiency in irrigation and public water supply networks and treatment and reuse of wastewater.

Efforts in the category of reducing water demand by changing production and consumption patterns, concentrate on limiting over-exploitation of water resources. Besides efforts to combat groundwater over-abstraction (Venot \& Molle, 2008), Jordan's national water strategy (Ministry of Water and Irrigation (MWI), 2009) includes plans to bound and regulate irrigated agriculture. Allocation efficiency is also a topic in the national water strategy, which acknowledges that water should be allocated to high value added purposes with relatively low water consumption, while ensuring that 
domestic water needs are fulfilled (Ministry of Water and Irrigation (MWI), 2009). Better water pricing and removing import tariffs on agricultural commodities should stimulate this (Ministry of Water and Irrigation (MWI), 2009). However, despite the attention to these strategies in Jordan's water strategy, practice shows a focus on meeting demand with supply-side measures, while efforts to manage demand face opposition from powerful entities as previously mentioned (Zeitoun et al., 2012).

Influencing dietary consumption patterns to reduce water demand remains unmentioned in the national water strategy (Ministry of Water and Irrigation (MWI), 2009) and does not seem to be on Jordan's policy agenda. The document does include goals on raising awareness, but these rather focus on informing the public on the water problems in Jordan so as to create support for intended regulations to increase water prices and limit abstractions and to provide "concrete suggestions on economically costefficient measures every individual can implement to reduce water demand" (Ministry of Water and Irrigation (MWI), 2009). The latter applies to water conservation techniques in the household, rather than choices in what to consume.

\subsection{Conclusions}

We have analysed Jordan's domestic water scarcity and pollution and the country's external water dependency and conclude that:

1. Even while taking into account the return flows, blue water scarcity in Jordan is severe;

2. Groundwater consumption is nearly double the groundwater availability;

3. Water pollution aggravates blue water scarcity;

4. While Jordan's dependence on transboundary resources is already large (34\%), its dependency on external water resources through trade is much larger, with $86 \%$ of the water consumption associated with the production of products and commodities consumed by the Jordan population taking place in foreign countries all over the world.

Subsequently, we have reviewed sustainable solutions that reduce the risk of this extreme water scarcity and dependency. A strategy for Jordan to mitigate the risks of extreme water scarcity and dependency should involve the following ingredients:

1. Do not tap into fossil groundwater resources; use only in urgent times, in low amounts and at low frequencies.

2. Drive desalination projects with sustainable solar and wind energy. 
3. Investigate and implement options for water harvesting and productive use of rainfall to overcome water shortages on the small scale.

4. Prevent pollution, treat inevitable waste streams, and possibly reuse wastewater flows, but consider that treated wastewater is not a new freshwater resource in addition to ground- and surface water and desalinated water.

5. Develop WF benchmarks for crops and products that reflect reasonable levels of water consumption per unit of production and work towards achieving those benchmarks by focusing on smart and efficient irrigation scheduling and improved soil and crop management.

6. Cap the WF in each river basin and aquifer to the maximum sustainable WF, focusing on groundwater first, while managing the risks of averted impact on surface water.

7. Increase allocation efficiency by making sure domestic water demand is met and using the remaining available water below the maximum sustainable level for the production of high value-added products and crops with relatively low WFs for export.

8. Use the revenue obtained by export to finance the inevitable imports of waterintensive products and commodities from a diverse number of countries that are under a significantly lower degree of water scarcity than Jordan.

9. Stimulate a change towards consumption patterns with a lower WF, e.g., by means of introducing meat-free days and product labelling.

10. The international community should assist Jordan in taking in the large numbers of refugees from neighbouring conflict regions, to reduce the domestic water demand.

With respect to these ingredients, Jordan's current water policy requires a strong redirection towards water demand management. Actual implementation of the plans in the national water strategy (against existing opposition) would be a first step. However, more attention should be paid to reducing water demand by changing the consumption patterns of Jordanian consumers. Moreover, unsustainable exploitation of the fossil Disi aquifer should soon be halted and planned desalination projects require careful consideration on the sustainability of their energy supply. 


\title{
4. Review and Classification of Indicators of Green Water Availability and Scarcity ${ }^{4}$
}

\begin{abstract}
Research on water scarcity has mainly focussed on blue water (ground- and surface water), but green water (soil moisture returning to the atmosphere through evaporation) is also scarce, because its availability is limited and there are competing demands for green water. Crop production, grazing lands, forestry and terrestrial ecosystems are all sustained by green water. The implicit distribution or explicit allocation of limited green water resources over competitive demands determines which economic and environmental goods and services will be produced and may affect food security and nature conservation. We need to better understand green water scarcity to be able to measure, model, predict and handle it. This paper reviews and classifies around 80 indicators of green water availability and scarcity, and discusses the way forward to develop operational green water scarcity indicators that can broaden the scope of water scarcity assessments.
\end{abstract}

\subsection{Introduction}

Freshwater is a renewable resource that is naturally replenished over time when moving through the hydrological cycle (Oki \& Kanae, 2006; Hoekstra, 2013). Precipitation forms the input of freshwater on land. Subsequently, it takes the blue or the green pathway back to the ocean and atmosphere before eventually returning as precipitation again (Falkenmark, 2003; Falkenmark \& Rockström, 2006; Falkenmark \& Rockström, 2010). The water that runs off to the ocean via rivers and groundwater is called the blue water flow. The green water flow is formed by the water that is temporarily stored in the soil and on top of vegetation and returns to the atmosphere as evaporation instead of running off (Hoekstra et al., 2011). As suggested by Savenije (2004), in this paper we use the term evaporation (instead of the often used term evapotranspiration) to refer to the vapour flux from land to atmosphere, which includes soil evaporation, evaporation of intercepted water, transpiration and in some cases (e.g. rice or swamp vegetation) openwater evaporation. About three-fifth of the precipitation over land takes the green path and two-fifth the blue path (Oki \& Kanae, 2006).

${ }^{4}$ This chapter has been published as:

Schyns, J.F., Hoekstra, A.Y. \& Booij, M.J. (2015) Review and classification of indicators of green water availability and scarcity, Hydrol. Earth Syst. Sci., 19: 4581-4608. 
Both blue and green water flows are made productive for human purposes. Blue water is used for industrial and domestic purposes and irrigation in agriculture. Green water sustains crop production, grazing lands, forestry and terrestrial ecosystems (Rockström, 1999; Rockström et al., 1999; Savenije, 2000; Gerten et al., 2005). These systems provide food, fibres, biofuels, timber and livestock products and other ecosystem services humans benefit from (Millennium Ecosystem Assessment, 2005; Gordon et al., 2010).

Although freshwater is renewable, this does not mean that its availability is unlimited. In fact, freshwater is also a finite resource (Hoekstra, 2013). Over a certain period, there falls a certain amount of precipitation. This limits both blue and green water availability in time. Human society cannot appropriate more water than is available. The finiteness of freshwater, in combination with the various competing demands for water, makes water a scarce resource.

Water scarcity is becoming increasingly important for multiple reasons. The growing world population leads to rising demands for food, energy and other water-consuming goods and services (Hejazi et al., 2014; WWAP, 2015). Moreover, people's diets are changing toward more livestock-based products, due to rising incomes and continuing urbanization (Molden, 2007). Such diets are more water and land intensive (Erb et al., 2009; Kastner et al., 2012; Odegard \& van der Voet, 2014). Policies towards more energy production from biomass create additional pressure on water and land (Hejazi et al., 2014). Additionally, a changing climate with increased variability and more extremes (IPCC, 2013) amplifies water scarcity (WWAP, 2014).

Given that green and blue water resources are limited and there are competing demands for both, green water as well as blue water are scarce. Therefore, it is surprising that research and debate on water scarcity have been, and still are, mainly focussed on blue water (Vörösmarty et al., 2000; Rijsberman, 2006; Vörösmarty et al., 2010; Wada et al., 2011; Hoekstra et al., 2012; WWAP, 2014, 2015). Although the importance of green water has increasingly gained acceptance since Falkenmark (1995) drew attention to it in the mid-1990s (Savenije, 2000; Rockström, 2001; Rijsberman, 2006; Liu et al., 2009; Hanasaki et al., 2010; Hoekstra \& Mekonnen, 2012), the notion of green water scarcity is addressed in the literature to a limited extent (Falkenmark et al., 2007; Falkenmark, 2013a,b). While the need to incorporate green water in water scarcity indicators and assessments has already been expressed since the beginning of this millennium (Savenije, 2000; Rockström, 2001; Rijsberman, 2006; Falkenmark \& Rockström, 2006), only a few attempts have been made so far in the form of combined green-blue water scarcity assessments 
(Rockström et al., 2009; Gerten et al., 2011; Kummu et al., 2014) (discussed in detail in Section 4.3.2).

Green water scarcity refers to the competition over limited green water resources and allocation over competing demands. This allocation occurs mostly implicitly and indirectly, since generally it is land that is been allocated to a certain use. This indirectness of allocation, together with the absence of a price, makes green water scarcity invisible in our economy. This does not mean, though, that green water resources are not scarce, since using green water for one purpose makes it unavailable for another purpose. We need to measure how scarce green water is in order to answer questions like following: Can we produce enough food, feed, fibres, bioenergy and forestry products with limited availability of water resources and suitable land? How can we do so without compromising natural ecosystems and other sectors that put a claim on water and land resources? For studying these crucial questions, a sole assessment of blue water scarcity is insufficient.

Therefore, it is due time that more attention is given to green water scarcity and how we can measure it. In this review, we make an inventory of existing indicators of green water availability and scarcity, and classify them based on their scope and purpose of measurement. The classification allows us to discuss similarities and differences between indicators and give advice on how the various indicator classes could be used to measure different kinds of green water availability or scarcity. This is useful in order to properly include limitations in green water availability in water scarcity assessments.

A review of green water scarcity indicators is new in its kind. Past reviews of water scarcity indicators (Savenije, 2000; Rijsberman, 2006) date back a while and hence do not include recent developments in the field, especially those related to the inclusion of green water. There exist multiple reviews of indicators of aridity (Wallén, 1967; Walton, 1969; Stadler, 2005) and drought (World Meteorological Organization, 1975; Wilhite \& Glantz, 1985; Maracchi, 2000; Tate \& Gustard, 2000; Keyantash \& Dracup, 2002; Heim, 2002; Hayes, 2007; Kallis, 2008; Mishra \& Singh, 2010; Sivakumar et al., 2010). We classify and discuss these indicators in an overarching way. First, we discuss the multiple dimensions of water availability and scarcity, and sharpen the scope of this review (Section 4.2). Next, we classify and review green water availability and scarcity indicators (Section 4.3). Finally, we draw conclusions and discuss future research directions (Section 4.4). 


\subsection{Multiple Aspects of Water Availability and Scarcity}

The concepts of water availability and scarcity are examined in Sections 4.2.1 to 4.2.4. We will reflect on these concepts in broad terms, not yet focussing on green water. In Section 4.2.5, we detail the scope of the indicators discussed in this paper.

\subsubsection{Water Availability and Scarcity}

A straightforward definition of water scarcity is: "an excess of water demand over available supply" (FAO, 2012b). Various other definitions of water scarcity exist that aim to be more inclusive.

"An imbalance between supply and demand of freshwater in a specified domain (country, region, catchment, river basin, etc.) as a result of a high rate of demand compared with available supply, under prevailing institutional arrangements (including price) and infrastructural conditions." (FAO, 2015a)

"When an individual does not have access to safe and affordable water to satisfy her or his needs for drinking, washing or their livelihoods we call that person water insecure. When a large number of people in an area are water insecure for a significant period of time, then we can call that area water scarce" (Rijsberman, 2006)

Considering these definitions, we can conclude that water scarcity is not something that is experienced by a single person at a particular moment (day or week). Rather, it is experienced by a larger community within a certain geographic area (e.g. catchment or country) and relates to larger timescales (months or years).

The concept of scarcity describes a relation between humans and nature (Baumgärtner et al., 2006). Nevertheless, we can distinguish water scarcity mainly caused by natural conditions of low water availability from scarcity mainly induced by a large human demand relative to natural availability. The latter can also occur in naturally waterabundant areas (Pereira et al., 2002).

Until now we have spoken about physical water scarcity, referring to the situation where there is insufficient water to meet human demand. If human, institutional and financial capital limit access to water, the term economic water scarcity applies (Seckler et al., 1999; Molden, 2007). In a broader sense, Ohlsson (2000) defines social resource scarcity as the situation in which social resources required to successfully adapt to physical water scarcity fall short. 


\subsubsection{Relative and Absolute Water Scarcity}

According to economic theory, water is a scarce good because it carries opportunity costs, which are the benefits foregone from possible alternative uses of the water (FAO, 2004). This is a form of "relative scarcity" based on the assumption of substitutability of goods (Baumgärtner et al., 2006). Water can be scarce in the relative sense also in waterabundant areas, because allocating water to purpose A implies it cannot be allocated to purpose B. In other words, water for purpose A is scarce in relation to water for other purposes. In common language we are inclined to say that sometimes water is scarce and at other times it is not. In economic sense, water is always scarce; the degree of water scarcity can vary though, and it can even be zero if alternative uses and thus competition is absent.

We speak of "absolute scarcity" when according to Baumgärtner et al. (2006) "scarcity concerns a non-substitutable means for satisfaction of an elementary need and cannot be levied by additional production". This means that in an area with a limited amount of water resources (that cannot be increased), at a certain level of consumption, water for elementary purposes (e.g. drinking and food production) will no longer be substitutable with water used for less essential purposes. In this case, there is absolute scarcity of water. Whether water is scarce in the absolute or relative sense thus depends on the degree of water scarcity: relative water scarcity turns into absolute scarcity when the boundaries of water exploitation are approached.

\subsubsection{Blue and Green Water}

Freshwater essentially stems from precipitation, which partitions into green and blue water (Falkenmark \& Rockström, 2006; Falkenmark \& Rockström, 2010). As discussed in the introduction of this paper, water availability and scarcity can pertain to both blue or green water resources, separately or in combination (Falkenmark, 2013a).

In contrast to the clear definition of blue water, various definitions of green water exist, defining it as an inflow (precipitation), a stock (rainwater in the soil) or an outflow (evaporation of rainwater). Often, the term green water is used to refer to "rainwater stored in the soil" or more specifically plant-available soil moisture in the unsaturated zone (Falkenmark et al., 2007; Falkenmark, 2013a); in this context the term green water is interpreted as a stock. Commonly, the distinction is made between green water stock and green water flow (Falkenmark \& Rockström, 2006; Falkenmark \& Rockström, 2010). The latter is an outflow, usually defined as actual evaporation over land (referring to the entire land-atmosphere vapour flux; see comment in the introduction), but it has also 
been defined as transpiration only (Savenije, 2000). Furthermore, some authors include precipitation (i.e. an inflow) in the definition of green water (Weiskel et al., 2014). The latter is in contrast with the definition of Falkenmark \& Rockström (2006) (adhered to in this paper) that precipitation is the undifferentiated freshwater resource. Scholars who have tried to quantify green water availability in water scarcity assessments defined it as the actual evaporation flux over land to the atmosphere (Rockström et al., 2009; Gerten et al., 2011; Kummu et al., 2014) (Section 4.3).

While not always made explicit in definitions, an accurate description of the green water storage and flow excludes the part of the storage and vapour flow that originates from blue water resources, which have been redirected to the soil moisture stock by means of irrigation, capillary rise or natural flooding (Hoekstra et al., 2011). In such cases, the green and blue contributions to the soil moisture can be tracked with a model-based water balance approach (see Chukalla et al. (2015)).

\subsubsection{Water Quantity and Quality}

Water scarcity is not only a function of the quantity of the water resource in relation to the demand, but also the quality of the resource in relation to the required quality for its end purpose (Pereira et al., 2002). If there is sufficient water available for a certain purpose, but it is polluted to such an extent that it is not usable for that purpose, then water can be considered scarce as long as the means are not available for cleaning the water to a desirable level. Pollution of water resources can thus aggravate water scarcity (FAO, 2012b).

Water quality in the case of green water differs from that of blue water. The quality of green water depends on soil properties such as nutrient availability, nutrient retention capacity and the presence of salts and toxic substances. However, close ties with blue water quality do exist. For example, blue water used for irrigation can increase soil salinity when the water is brackish or saline and it can also flush out excess nutrients and other substances.

\subsubsection{Scope of the Review and Classification}

This paper focuses on green water, water quantity and physical water scarcity and treats of both green water availability and scarcity. In the next section, we consider indicators within this scope, including indicators of aridity, agricultural, meteorological and vegetation drought, soil moisture availability and overall green-blue water scarcity. The focus of this paper implies that several concepts and indicators fall outside the scope of 
the classification.. The concepts and indicators focussing on blue water that are outside the scope of this paper are the following:

- Hydrological drought: concerns the effects of dry periods on surface and subsurface flows and stocks and is therefore related to blue water. Examples of associated indicators are surface water supply index (Shafer \& Dezman, 1982); Palmer Hydrological Drought Index (Karl, 1986); several indicators reviewed by Smakhtin (2001).

- Blue water scarcity: measures demand for blue water resources versus blue water availability and is thus purely related to blue water. Examples of associated indicators are the water crowding indicator (Falkenmark et al., 1989), the withdrawal-to-discharge ratio (Vörösmarty et al., 2000), water poverty index (Sullivan et al., 2003), water stress indicator (Smakhtin et al., 2004), water stress index (Pfister et al., 2009), dynamic water stress index (Wada et al., 2011) and blue water scarcity (Hoekstra et al., 2012). Note that some of these indicators also incorporate more than only physical elements of water scarcity (e.g. water poverty index).

The concepts related to broader forms of water scarcity than physical water scarcity that are outside the scope of this paper are the following:

- Socio-economic drought: concerns imbalances in supply and demand of economic goods due to the physical characteristics of drought (Wilhite \& Glantz, 1985; American Meteorological Society, 2013) with effects on the economy and society. The American Meteorological Society (2013) mentions the following effects: loss of income from lower crop yields, reduced spending in rural communities, health issues and mass migration.

- Social resource scarcity: see Section 4.2.1.

Furthermore, the review and classification in this paper excludes indicators that measure drought by combining multiple drought indicators (classified individually) and sometimes other information such as land use maps. Examples of such indicators are the US Drought Monitor (Svoboda et al., 2002) and the Vegetation Drought Response Index (Brown et al., 2008).

\subsection{Green Water availability and Scarcity Indicators}

We have identified around 80 indicators of green water availability and scarcity, which we classify into the following categories: 
1. Green water availability indicators show whether green water availability is low or high and are insensitive to actual water demand. In other words, when the water demand increases, indicator values will not reflect this. Within this category we distinguish absolute and relative green water availability indicators:

a. Absolute green water availability indicators measure actual conditions of green water availability (in an absolute sense).

b. Relative green water availability indicators measure actual conditions of green water availability compared to conditions that are perceived as normal, which is often defined as the climate-average or median value of the variable of interest.

Note that this distinction between absolute and relative indicators is unrelated to and different from the concepts of relative and absolute scarcity earlier discussed in Section 4.2.2.

2. Green water scarcity indicators incorporate elements of both water availability and demand and therefore respond - in contrast to green water availability indicators - to changes in water demand as well. We distinguish three different options to measure green water scarcity conceptually (explanation in Section 4.3.2):

a. green water crowding;

b. green water requirements for self-sufficiency versus green water availability;

c. actual green water consumption versus green water availability.

The term green water availability is basically used in two different ways. When we speak of green water availability indicators (Section 4.3.1), we refer to indicators that measure the availability of green water in one way or another, without considering availability in relation to an actual demand for green water. This is in contrast with green water scarcity indicators that always compare demand to availability. In the case of green water scarcity indicators, the term green water availability specifically refers to the part of the green water flow available for biomass production for human purposes (Section 4.3.2). Also the term demand occurs in two different contexts. When we speak of demand in the context of green water scarcity, we refer to the demand for green water, associated with the production of biomass for human purposes. 
Table 4-1. Overview of indicator categories.

\begin{tabular}{|c|c|c|c|}
\hline $\begin{array}{l}\text { Indicator } \\
\text { category } \\
\text { (parent } \\
\text { category) }\end{array}$ & Measures & $\begin{array}{l}\text { Human factors } \\
\text { of direct } \\
\text { influence }\end{array}$ & Purposes \\
\hline $\begin{array}{l}\text { Aridity } \\
\text { (absolute green } \\
\text { water } \\
\text { availability) }\end{array}$ & $\begin{array}{l}\text { Long-term } \\
\text { annual climatic } \\
\text { balance } \\
\text { between } \\
\text { precipitation } \\
\text { and } \\
\text { evaporation. }\end{array}$ & - & $\begin{array}{l}\text { Classification of climates; } \\
\text { characterization of (semi)-arid } \\
\text { zones. }\end{array}$ \\
\hline $\begin{array}{l}\text { Agricultural } \\
\text { drought } \\
\text { (absolute green } \\
\text { water } \\
\text { availability) }\end{array}$ & $\begin{array}{l}\text { Actual soil } \\
\text { moisture } \\
\text { availability } \\
\text { versus crop } \\
\text { water demand } \\
\text { for non-water } \\
\text { limited growth. }\end{array}$ & $\begin{array}{l}\text { Soil } \\
\text { management } \\
\text { affecting } \\
\text { infiltration and } \\
\text { groundwater } \\
\text { recharge } \\
\text { (percolation); } \\
\text { crop } \\
\text { management. }\end{array}$ & $\begin{array}{l}\text { Assessing the extent to which } \\
\text { crop growth is adversely } \\
\text { affected by limiting soil } \\
\text { moisture conditions; linking } \\
\text { drought conditions to yield } \\
\text { losses. }\end{array}$ \\
\hline $\begin{array}{l}\text { Absolute soil } \\
\text { moisture } \\
\text { (absolute green } \\
\text { water } \\
\text { availability) }\end{array}$ & $\begin{array}{l}\text { Actual soil } \\
\text { moisture } \\
\text { availability. }\end{array}$ & $\begin{array}{l}\text { Soil } \\
\text { management } \\
\text { affecting } \\
\text { infiltration and } \\
\text { groundwater } \\
\text { recharge } \\
\text { (percolation). }\end{array}$ & $\begin{array}{l}\text { Monitoring spatial and } \\
\text { temporal variation in soil } \\
\text { moisture availability; } \\
\text { analysing the correlation } \\
\text { between soil moisture } \\
\text { availability and crop } \\
\text { evaporation and yields; } \\
\text { warning for onset of } \\
\text { agricultural drought. }\end{array}$ \\
\hline
\end{tabular}


Table 4-1 (continued). Overview of indicator categories.

\begin{tabular}{|c|c|c|c|}
\hline $\begin{array}{l}\text { Indicator } \\
\text { category } \\
\text { (parent } \\
\text { category) }\end{array}$ & Measures & $\begin{array}{l}\text { Human factors } \\
\text { of direct } \\
\text { influence }\end{array}$ & Purposes \\
\hline $\begin{array}{l}\text { Agricultural } \\
\text { suitability } \\
\text { under rain-fed } \\
\text { conditions } \\
\text { (absolute green } \\
\text { water } \\
\text { availability) }\end{array}$ & $\begin{array}{l}\text { Land } \\
\text { suitability for } \\
\text { rain-fed crop } \\
\text { production } \\
\text { based on } \\
\text { climate- } \\
\text { average } \\
\text { temperature } \\
\text { and } \\
\text { precipitation } \\
\text { conditions, } \\
\text { crop and soil } \\
\text { characteristics } \\
\text { and terrain } \\
\text { slope. }\end{array}$ & $\begin{array}{l}\text { Level of } \\
\text { agricultural } \\
\text { inputs and } \\
\text { management. }\end{array}$ & $\begin{array}{l}\text { Agro-ecological zoning; } \\
\text { determining a location's } \\
\text { potential for rain-fed } \\
\text { agriculture (yield gap } \\
\text { analysis). }\end{array}$ \\
\hline $\begin{array}{l}\text { Meteorological } \\
\text { drought } \\
\text { (relative green } \\
\text { water } \\
\text { availability) }\end{array}$ & $\begin{array}{l}\text { Whether there } \\
\text { is relatively } \\
\text { little } \\
\text { precipitation or } \\
\text { whether the } \\
\text { normal balance } \\
\text { between } \\
\text { precipitation } \\
\text { and potential } \\
\text { evaporation is } \\
\text { distorted. }\end{array}$ & - & $\begin{array}{l}\text { Drought monitoring as a basis } \\
\text { for early warning systems and } \\
\text { decision-support tools; } \\
\text { assessing drought severity } \\
\text { based on intensity, duration } \\
\text { and spatial extent; comparison } \\
\text { of historic drought events. }\end{array}$ \\
\hline
\end{tabular}


Table 4-1 (continued). Overview of indicator categories.

\begin{tabular}{|c|c|c|c|}
\hline $\begin{array}{l}\text { Indicator } \\
\text { category } \\
\text { (parent } \\
\text { category) }\end{array}$ & Measures & $\begin{array}{l}\text { Human factors } \\
\text { of direct } \\
\text { influence }\end{array}$ & Purposes \\
\hline $\begin{array}{l}\text { Vegetation } \\
\text { drought } \\
\text { (relative green } \\
\text { water } \\
\text { availability) }\end{array}$ & $\begin{array}{l}\text { Greenness of } \\
\text { vegetation } \\
\text { relative to } \\
\text { historical } \\
\text { observations of } \\
\text { greenness. }\end{array}$ & $\begin{array}{l}\text { Pruning or } \\
\text { clearing; } \\
\text { prevention of } \\
\text { plant disease. }\end{array}$ & $\begin{array}{l}\text { Assessment of drought impact } \\
\text { on vegetation; early drought } \\
\text { detection; studying the } \\
\text { correlation between vegetation } \\
\text { health and soil moisture } \\
\text { availability, thermal } \\
\text { conditions and crop yields. }\end{array}$ \\
\hline $\begin{array}{l}\text { Relative soil } \\
\text { moisture } \\
\text { (relative green } \\
\text { water } \\
\text { availability) }\end{array}$ & $\begin{array}{l}\text { Whether the } \\
\text { soil is dryer or } \\
\text { wetter than } \\
\text { normal. }\end{array}$ & $\begin{array}{l}\text { Soil } \\
\text { management } \\
\text { affecting } \\
\text { infiltration and } \\
\text { groundwater } \\
\text { recharge } \\
\text { (percolation). }\end{array}$ & $\begin{array}{l}\text { Monitoring spatial and } \\
\text { temporal variation in relative } \\
\text { soil moisture availability; } \\
\text { analysing the correlation } \\
\text { between soil moisture } \\
\text { availability and crop yields. }\end{array}$ \\
\hline $\begin{array}{l}\text { Green water } \\
\text { crowding } \\
\text { (green water } \\
\text { scarcity) }\end{array}$ & $\begin{array}{l}\text { The potential } \\
\text { of a geographic } \\
\text { area to reach } \\
\text { self-sufficiency } \\
\text { based on its } \\
\text { available green } \\
\text { water } \\
\text { resources. }\end{array}$ & $\begin{array}{l}\text { Consumption } \\
\text { pattern (diet } \\
\text { composition); } \\
\text { population } \\
\text { growth; land } \\
\text { use changes. }\end{array}$ & $\begin{array}{l}\text { Studying green water } \\
\text { availability in relation to } \\
\text { hypothetical green water } \\
\text { requirements for self- } \\
\text { sufficiency; identifying } \\
\text { geographic areas that have too } \\
\text { limited green water } \\
\text { availability for self-sufficiency } \\
\text { and are dependent on blue } \\
\text { water resources and virtual } \\
\text { water import (assessing food } \\
\text { security). }\end{array}$ \\
\hline
\end{tabular}


Table 4-1 (continued). Overview of indicator categories.

\begin{tabular}{|c|c|c|c|}
\hline $\begin{array}{l}\text { Indicator } \\
\text { category } \\
\text { (parent } \\
\text { category) }\end{array}$ & Measures & $\begin{array}{l}\text { Human factors } \\
\text { of direct } \\
\text { influence }\end{array}$ & Purposes \\
\hline $\begin{array}{l}\text { Green water } \\
\text { requirements } \\
\text { for self- } \\
\text { sufficiency } \\
\text { versus green } \\
\text { water } \\
\text { availability } \\
\text { (green water } \\
\text { scarcity) }\end{array}$ & $\begin{array}{l}\text { Idem to green } \\
\text { water } \\
\text { crowding } \\
\text { indicators. }\end{array}$ & $\begin{array}{l}\text { Consumption } \\
\text { pattern (diet } \\
\text { composition); } \\
\text { population } \\
\text { growth; crop } \\
\text { and soil } \\
\text { management } \\
\text { affecting water } \\
\text { productivities; } \\
\text { land use } \\
\text { changes. }\end{array}$ & $\begin{array}{l}\text { Idem to green water crowding } \\
\text { indicators. }\end{array}$ \\
\hline $\begin{array}{l}\text { Actual green } \\
\text { water } \\
\text { consumption } \\
\text { versus green } \\
\text { water } \\
\text { availability } \\
\text { (green water } \\
\text { scarcity) }\end{array}$ & $\begin{array}{l}\text { The degree to } \\
\text { which the } \\
\text { available green } \\
\text { water } \\
\text { resources in a } \\
\text { geographic } \\
\text { area have been } \\
\text { appropriated, } \\
\text { i.e. the extent } \\
\text { to which the } \\
\text { green water } \\
\text { footprint has } \\
\text { reached its } \\
\text { maximum } \\
\text { sustainable } \\
\text { level. }\end{array}$ & $\begin{array}{l}\text { Consumption } \\
\text { pattern (diet } \\
\text { composition); } \\
\text { population } \\
\text { growth; } \\
\text { production } \\
\text { pattern; crop } \\
\text { and soil } \\
\text { management } \\
\text { affecting water } \\
\text { productivities; } \\
\text { land use } \\
\text { changes. }\end{array}$ & $\begin{array}{l}\text { Studying the competition over } \\
\text { limited green water resources } \\
\text { and allocation over competing } \\
\text { demands. }\end{array}$ \\
\hline
\end{tabular}




\section{Influencing factors:}

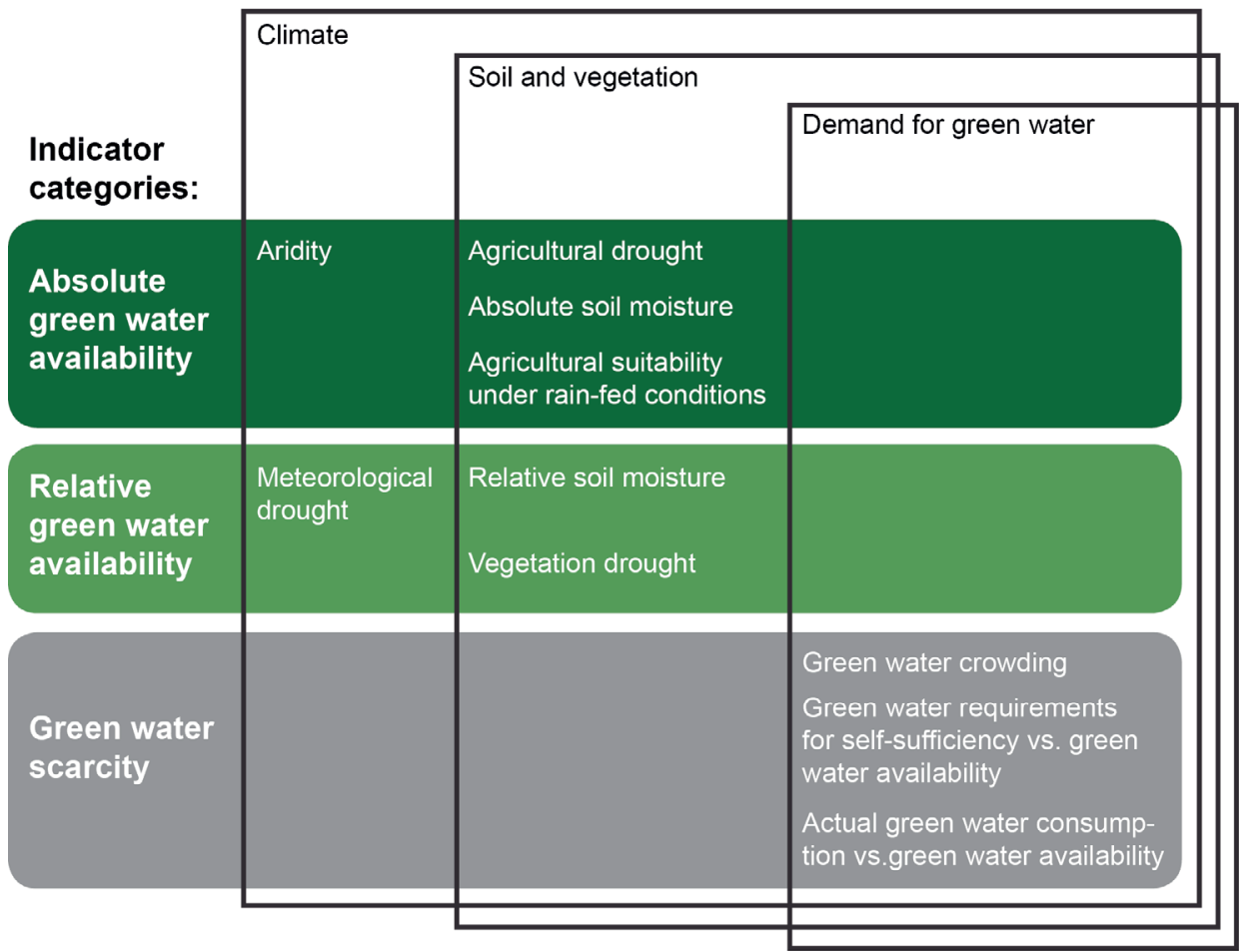

Figure 4-1. Conceptual diagram of indicator categories and the factors that influence them.

In the discussion of agricultural drought indicators in Section 4.3.1, the term crop moisture/evaporation/water demand is used to refer to the water needs of the crop for non-water limited growth.

The indicator categories will be discussed in the following sections. Table 4-1 provides an overview of the categories and summarizes what they measure, which human factors directly influence them and what they are used for. Furthermore, the conceptual diagram in Figure 4-1 displays the indicator categories and the factors that influence them.

\subsubsection{Green Water Availability Indicators}

Indicators of green water availability fall apart in indicators that measure availability in an absolute sense or in terms of relative to normal conditions. These two categories are treated in the next two subsections. Descriptions of various specific green water availability indicators that fall in the two categories are included in Appendices B.1 And B.2. The indicator abbreviations used in this section are defined in these appendices. 


\subsubsection{Absolute Green Water Availability Indicators}

Indicators in this category measure green water availability in a certain area (or location) and period (or moment) in an absolute sense. We find here indicators of aridity, agricultural drought, soil moisture and agricultural suitability, which are subsequently discussed in the following. Aridity are purely climatic, while the others are also influenced by the characteristics and management of the soil and vegetation.

\section{Aridity Indicators}

Aridity is seen as a permanent feature of a climate, consisting of low average annual precipitation and/or high evaporation rates, often resulting in low soil moisture availability (Pereira et al., 2002; Heim, 2002; Kallis, 2008). As such, one can say that an aridity map shows the preconditions for vegetation (Falkenmark \& Rockström, 2004). Aridity indicators are usually based on long-term average annual comparisons of precipitation versus potential evaporation, temperature or atmospheric saturation deficit, whereby the latter two were often used in the twentieth century as proxies for potential evaporation due to lack of data. They have been used for the classification of climates, specifically the characterization of (semi-)arid zones. Some more recently developed aridity indicators compare the actual rather than potential evaporation rate with precipitation (ER, HU-ER). These indicators reflect the actual availability of water at a given location (also from lateral fluxes) for meeting the evaporative demand of the atmosphere.

The SCMD by Wilhelmi et al. (2002) is somewhat different than the classical aridity indicators. It shows the probability of seasonal crop moisture deficiency based on a combination of long-term precipitation records and area-weighted evaporation of the mixture of crops grown in the study area. Wilhelmi \& Wilhite (2002) apply the SCMD to assess agricultural drought vulnerability in Nebraska. We classify the SCMD here under the aridity indicators, because like most aridity indicators, it measures precipitation versus evaporation and is calculated for a historical time period, thus representing a long-term average.

\section{Agricultural Drought Indicators}

According to the World Meteorological Organization (1975), agricultural drought indicators "indirectly express the degree to which growing plants have been adversely affected by an abnormal moisture deficiency", which may be the result of an unusually small moisture supply or an unusually large moisture demand (World Meteorological Organization, 1975). Formulated differently by Sivakumar (2010): “Agricultural drought 
depends on the crop evapotranspiration demand and the soil moisture availability to meet this demand."

Therefore, the bulk of agricultural drought indicators measures crop-available water compared to crop water needs for non-water limited growth (i.e. potential evaporation) and are usually applied on a daily, weekly, monthly or seasonal basis (Woli et al., 2012). Some indicators measure the plant water deficit more specifically by looking at the difference between actual and potential transpiration (e.g. DTx and WDI). Agricultural drought indicators can be influenced by soil management that affects the rates of infiltration and percolation and thus the water available to the crop.

Drought is typically a relative-to-normal phenomenon as will be discussed in Section 4.3.1.2. Agricultural drought indicators, which measure actual relative to potential evaporation, are relative indicators in another way, though. They do not compare actual with normal conditions. Instead, they compare moisture supply with a crop water demand in the ideal case of non-water limited growth. Therefore these indicators actually measure absolute green water availability (actual evaporation), set against this crop water demand. In fact, these indicators say more about the demand for blue water (irrigation) to ensure non-water limited crop growth than they do about green water availability. Some indicators do somehow compare the actual to potential evaporation ratio with a multi-year average (or median) of this ratio and are thus in essence relative indicators according to our classification. Examples are the CMI, DSI and GrWSI and anomalies of the ESI and WS. Nevertheless, they are classified as agricultural drought indicators because they, like most of the others, measure actual to potential evaporation..

A note is required on the GWSI by Nunez et al. (2013) of which the name suggests that it is a green water scarcity indicator. Nevertheless, we classify it as an agricultural drought indicator, because it measures actual moisture supply versus crop-specific reference evaporation, albeit on a larger timescale (3-year crop rotation) than most other agricultural drought indicators.

\section{Absolute Soil Moisture Indicators}

Multiple indicators provide a measure of the absolute amount of soil moisture available at a given location and moment (or summed over a period), be it on the basis of field measurements (e.g. SMIX, SMI) and/or modelling of the soil water balance (e.g. AvgGWS and SD-GWS) or remote sensing data (e.g. TVDI, MPDI). They can be used for monitoring spatial and/or temporal variations in soil moisture availability. Temporal analysis of soil moisture availability can warn for the onset of agricultural drought, or in 
contrast, the proneness to flash floods (Hunt et al., 2009). Several of these indicators have been introduced and applied as indicators of agricultural drought (e.g. ADD, SMDI, SMIX, SMI), analysing the correlation between soil moisture availability and crop yields. Therefore, they are typically calculated on intra-annual timescales.

It should be noted that the soil moisture can partially be blue - also under rain-fed conditions - due to capillary rise or natural flooding (Section 4.2.3). This note also applies to the other indicators that are not purely based on climatic factors (Figure 4-1).

\section{Agricultural Suitability under Rain-fed Conditions}

Maps that classify land according to agricultural suitability under rain-fed conditions (green water only) are indirect measures of green water availability in the absolute sense. Up to date, two global studies have made such land suitability classifications for rain-fed crop production for climate-average temperature and precipitation conditions and taking into account crop characteristics, various soil parameters and terrain slope: GAEZ (IIASA/FAO, 2012) and GLUES (Zabel et al., 2014). The GAEZ study additionally considers various levels of agricultural input/management. Both studies classify lands as not suitable, marginally suitable, moderately suitable or highly suitable. This classification shows where the climate, soil and topographic conditions are more or less suitable for agricultural production with green water only. In other words, where aridity maps show the preconditions for vegetation in general (Falkenmark \& Rockström, 2004), these maps show the preconditions for rain-fed crop production, therein considering crop, soil and terrain parameters in addition to climate.

\subsubsection{Relative Green Water Availability Indicators}

Indicators in this category measure green water availability relative to a normal condition and are usually calculated on intra-annual scales. As opposed to aridity, drought is often defined as a condition relative to what is perceived as a normal amount of precipitation or balance between precipitation and evaporation (World Meteorological Organization, 1975; Wilhite \& Glantz, 1985). Droughts are often termed temporary, uncertain and difficult to predict features characterized by lower-than-average precipitation (Pereira et al., 2002; Heim, 2002; Kallis, 2008; Mishra \& Singh, 2010; FAO, 2015a). Therefore, indicators of meteorological drought and vegetation drought are classified into the category of relative green water availability indicators. Indicators that measure soil moisture in a relative sense are included in this category as well. Just like aridity indicators, meteorological drought indicators are solely based on climatic variables. The other two subcategories are also affected by the soil and vegetation and 
how they are managed. The three subcategories are sequentially discussed in the following.

\section{Meteorological Drought Indicators}

Meteorological drought indicators fall apart in indicators that are solely based on precipitation (e.g. SPI) and those that consider both precipitation and potential evaporation (e.g. PDSI, RDI, SPEI). These indicators show whether there is relatively little precipitation or whether the normal balance between precipitation and evaporation is distorted. Unlike aridity indicators, which are generally based on long-term annual averages reflecting climate, these indicators capture variations in the weather. They are applied for monitoring the intensity, duration and spatial extent of droughts and determining drought severity based on these characteristics. This is useful for recognizing droughts and comparing them with past drought, which serves as a basis for early warning systems and decision-support tools.

\section{Vegetation Drought Indicators}

Vegetation drought indicators show the drought impact on vegetation by measuring the weather-related variations in greenness of vegetation. They reflect whether vegetation greenness is deviating from regular conditions. They can be used for studying the correlation between vegetation health and soil moisture availability, thermal conditions and crop yields (Kogan, 2001). Since the vegetation drought indicators we have identified are all based on remote sensing observations, the indicators do not directly show whether deviations are caused by relatively dry weather (i.e. meteorological drought) or by other factors influencing vegetation growth (e.g. plant diseases or human interference such as pruning and clearing). Satellite-based vegetation drought indicators respond to subtle changes in vegetation canopy, which makes them suitable for early drought detection (Kogan, 2001).

\section{Relative Soil Moisture Indicators}

In contrast to the absolute soil moisture indicators discussed in Section 4.3.1.1, these indicators measure the moisture conditions at a given location relative to a normal condition. Identified examples are the PZI, SMAI and SD. These indicators have similar uses as absolute soil moisture indicators. They are also used to correlate soil moisture conditions to crop yields and are considered suitable for measuring agricultural droughts (Keyantash \& Dracup, 2002; Narasimhan \& Srinivasan, 2005). 


\subsubsection{Green Water Scarcity Indicators}

As put forward in Section 4.2, water scarcity pertains to a situation with a high water demand compared to water availability, which is experienced by a community (numerous people) within a certain geographic area (e.g. catchment or country) over a significant period of time (months or years). We can then define green water scarcity as the degree of competition over limited green water resources, whereby the demand for green water resources to sustain the production of a desirable level of biomass-based products within a certain geographic area is somehow compared to the available green water resources in space and time.

Since production of biomass-based products (food, fibres, biofuels, timber) generally takes place in cycles of 1 year (or more in case of perennials and forestry), this definition of green water scarcity incorporates the significant-period-of-time element in the imbalance between green water demand and availability. Furthermore, limited production of biomass-based products affects numerous people, both producers and consumers.

As opposed to the indicators discussed in Section 4.3.1, indicators of green water scarcity thus need to include a measure of green water demand, associated with the production of biomass for human purposes, compared to green water availability. In other words, they should measure the green water demand related to crop production, grazing lands and forestry in relation to green water availability. Note that the term green water availability here refers to the part of the green water flow available for biomass production for human purposes (in space and time); it thus excludes green water flows that are effectively unavailable, for instance green water flows in unsuitable areas (e.g. because of steep slopes) or green water flows in cold parts of the year unsuitable for growth.

We distinguish three different options to measure green water scarcity conceptually:

1. Green water crowding: per capita available green water resources in an area compared to a global average threshold representing the amount of green water required to sustain a person's standard consumption pattern of biomass-based products;

2. Green water requirements for self-sufficiency versus green water availability: green water requirements for producing the consumed biomass-based products within a certain geographic area, assuming self-sufficiency within the geographic area, compared to the green water resources in the geographic area; 
3. Actual green consumption versus green water availability: actual green water consumption in a certain geographic area (associated with the actual production of biomass for human purposes) compared to green water availability in the area. This type of indicator thus acknowledges the possibility of virtual water trade as opposed to assuming self-sufficiency as in the previous two types of indicators.

In Sections 4.3.2.1 and 4.3.2.2, we discuss existing indicators that measure overall greenblue water scarcity and reflect on how these indicators could be adapted to measure green water scarcity specifically, according to above-mentioned options (1) and (2). In Section 4.3.2.3, we elaborate upon a third way of measuring green water scarcity that has yet to be brought into practice. The challenges for operationalization of these green water scarcity indicators are discussed in Section 4.3.2.4. Finally, in Section 4.3.2.5 we reflect on green water scarcity indicators versus indicators that measure overall greenblue water scarcity.

\subsubsection{Green Water Crowding}

Rockström et al. (2009) introduced a combined green-blue water shortage index, which compares the sum of green and blue water availability with a global average threshold of $1,300 \mathrm{~m}^{3} / \mathrm{cap} / \mathrm{yr}$. This threshold represents the green and blue water requirements for sustaining a global average standard diet. When green-blue water availability drops below the threshold, this indicates a shortage of green-blue water resources in the study area and reflects the area's dependency on external water resources. The green-blue water shortage index is an indicator of water crowding, similar to Falkenmark's bluewater-focussed water crowding indicator (Falkenmark et al., 1989).

Similar to the indicator by Rockström et al. (2009), an indicator of green water crowding could be defined as the per capita available green water resources in an area compared to a global average threshold representing the amount of green water required to sustain a person's standard consumption pattern. We intentionally speak here of a consumption pattern, because green water is required not only to produce food, but also to produce other biomass-based products humans consume, such as fibres, biofuels and forestry products. As such, the measure of green water requirements we propose here is broader than the definition of a standard diet according to Rockström et al. (2009) (and Gerten et al. (2011) and Kummu et al. (2014)), which only pertains to water requirements for food production. 
Rockström et al. (2009) define green water availability as "the soil moisture available for productive vapour flows from agricultural land". Technically, they calculate green water availability as actual evaporation from existing cropland and permanent pasture, reduced by a factor 0.85 that accounts for minimum evaporation losses that are unavoidable in agricultural systems (Rockström et al., 2009). This definition is dependent on the extent of agricultural land and excludes available green water on lands that are currently uncultivated, but have potential to be used productively in a sustainable manner.

\subsubsection{Green Water Requirements for Self-sufficiency versus Green Water Availability}

Gerten et al. (2011) and Kummu et al. (2014) elaborated on the work by Rockström et al. (2009) by further developing and applying the overall green-blue water scarcity indicator. Instead of using a global average, Gerten et al. (2011) calculate the green-blue water requirements for sustaining a standard diet on the national level based on local crop water productivities and compare this with the sum of green and blue availability in each country of the world. The resulting green-blue water scarcity indicator, computed for each country, is defined as the ratio between green-blue water availability and green-blue water requirements for producing the standard diet. They define green water availability similar to Rockström et al. (2009), but a bit more conservative: they do not assume year-round evaporation from areas covered with their category of other crops that they parameterized as perennial grass, since this category includes non-food crops and crops that grow only during a part of the year (Gerten et al., 2011).

Whereas the studies by Rockström et al. (2009) and Gerten et al. (2011) are based on climate-averages, Kummu et al. (2014) apply the green-blue water scarcity indicator by Gerten et al. (2011) on a year-by-year basis to account for inter-annual climate variability on the scale of food producing units, the scale at which demand for water and food is assumed to be managed according to the authors. Kummu et al. (2014) measure the frequency of years in which green-blue water availability falls short of green-blue water requirements, on which they base their classification of green-blue scarcity: no scarcity, occasional scarcity (subdivided in four levels) or chronic scarcity.

The green-blue water scarcity indicator shows the potential of a geographic area (e.g. country or food producing unit) to reach food self-sufficiency and reflects its dependency on trade in agricultural commodities and associated virtual water (Kummu et al., 2014). A similar indicator for green water could show an area's green water demand (for self-sufficiency in biomass-based products, for sustaining the standard 
consumption pattern) compared to green water availability in the area. It would also reflect an area's dependency on internal blue water resources and virtual water trade.

For the potential green water scarcity indicators discussed in Sections 4.3.2.1 and 4.3.2.2, a more comprehensive definition of green water availability is advised than the one applied by Rockström et al. (2009), Gerten et al. (2011) and Kummu et al. (2014). An example of a more comprehensive definition is discussed in the following section.

\subsubsection{Actual Green Water Consumption versus Green Water Availability}

The green water scarcity indicator by Hoekstra et al. (2011) compares the actual green water consumption in an area associated with the actual biomass production pattern (hence considering virtual water trade as opposed to assuming self-sufficiency) with green water availability in the area. Green water scarcity is defined as the ratio of the total green water footprint in a catchment in a period (e.g. a year) over green water availability.

The sum of green water footprints equals all actual evaporation (Eact) related to biomass production for human purposes (i.e. agriculture and forestry) excluding the part of the vapour flow that originates from blue water resources (irrigation). Note that for cases where land use is partly natural and partly for human production (e.g. a semi-natural production forest), the green water demand related to human production would need to be expressed as a fraction of the total green water flow. Methods to do so for a production forest are discussed by Van Oel \& Hoekstra (2012). Green water availability is defined as total Eact over the catchment minus Eact from land reserved for natural vegetation (so-called environmental green water requirement) and minus Eact from land that cannot be made productive, e.g. in areas or periods of the year that are unsuitable for crop growth (Hoekstra et al., 2011). In fact, green water availability defined like this, represents the maximum sustainable green water footprint in the catchment and period under consideration. Hence, the green water scarcity ratio shows the extent to which the green water footprint has reached its maximum sustainable level. Of course, this definition can also be applied to other geographical units than a catchment.

The definition of green water availability by Hoekstra et al. (2011) is more comprehensive than the one used by Rockström et al. (2009), Gerten et al. (2011) and Kummu et al. (2014). However, this is also the reason why the indicator has not been made operational yet. Difficulties remain in estimating the amount of land that needs to be reserved for nature and when and where the green water flow cannot be made 
productive (Hoekstra et al., 2011). These challenges are discussed in the following section.

Furthermore, the indicator does not deal with green water scarcity at a particular site as looked upon by Falkenmark et al. (2007) and Falkenmark (2013a). They describe green water scarcity as an issue of lower-than-potential plant-accessible water in the root zone and the occurrence of unproductive evaporation losses from the field, which results in lower yields than potentially achievable. First, blue water losses in the form of surface run-off and percolation decrease the plant-accessible water in the root zone (smaller green water flow) (Rockström \& Falkenmark, 2000). Such losses are the result of a soil's low infiltration capacity (e.g. soil crusting) and poor soil water holding capacity, but can be caused or aggravated by human action through soil mismanagement (Falkenmark, 2013a). Second, low root/crop water uptake capacity leads to unproductive evaporation losses (green water flow not entirely productive) (Rockström \& Falkenmark, 2000). Transpiration is a productive form of green water use, contributing to biomass production, while other components of the evaporative flow are regarded as unproductive (Rockström \& Falkenmark, 2000; Rockström, 2001; Rockstrom et al., 2007; Savenije, 2004). Rockstrom et al. (2007) express the productivity of green water use as the ratio of transpiration to evaporation. Rockström et al. (2009) call this the transpiration efficiency. This transpiration efficiency is complementary to the green water scarcity indicator by Hoekstra et al. (2011). A green water scarcity assessment based on both will give insight into the severity of green water scarcity: areas that are considered highly green-water scarce, but have a low transpiration efficiency, may have options to improve the latter and thereby yields, which may lower the green water scarcity.

\subsubsection{Challenges for Operationalization of Green Water Scarcity Indicators}

Operationalization of green water scarcity indicators faces three major challenges, particularly regarding the quantification of green water availability. First, the determination of which areas and periods of the year the green water flow can be used productively is not straightforward. Absolute green water availability indicators, in particular land classifications of agricultural suitability, can provide insight in the availability of green water in the spatial dimension. Relative green water availability indicators can enrich the picture by showing which areas are prone to large inter- and intra-annual variations in green water availability, making these areas less suitable for (certain types of) biomass production. To estimate which part of the green water flow can be used productively in time, advanced crop growth models (like APSIM (McCown et al., 1995; Holzworth et al., 2014), AquaCrop (Steduto et al., 2009), CropSyst (Stöckle et 
al., 2003), EPIC (Jones et al., 1991) or SWAP/WOFOST (van Dam et al., 2008)) can be used to simulate water-limited yields and actual evaporation for various cropping periods and different types of soil, crop and agricultural water management (e.g. adding blue water in the form of deficit irrigation during a dry spell, might make it possible for the crop to survive and use the green water flow later in the year productively).

Second, estimating green water consumption of forestry is difficult, because it entails separation of production forest evaporation into green and blue parts. This is problematic, because trees generally root so deep that, by means of capillary rise, they directly take up water from groundwater (blue) in addition to the soil moisture (green) (Hoekstra, 2013).

Third, research is required to determine the environmental green water requirements, i.e. the green water flow that should be preserved for nature, similar to the environmental flow requirements for blue water. Key here is the identification of areas that need to be reserved for nature and biodiversity conservation. It is known that the current network of protected areas is insufficient to conserve biodiversity (Rodrigues et al., 2004a; Rodrigues et al., 2004b; Venter et al., 2014; Butchart et al., 2015) and that attention should be paid to conservation of biodiversity in production landscapes that are shared with humans (Baudron \& Giller, 2014). The 11th Aichi Biodiversity Target is to expand the protected area network, which currently has a terrestrial coverage of about 14.6\% (Butchart et al., 2015), to at least 17\% terrestrial coverage by 2020 (Convention on Biological Diversity, 2010). However, to properly assess the limitations to green water availability, spatially explicit information on the additional areas to be preserved is required. The best-available data regarding this are recently published work by Pouzols et al. (2014). These authors have mapped global and national priority areas for expansion of the protected area network on 0.2 degree spatial resolution and assessed associated conservation gains (Pouzols et al., 2014; Brooks, 2014).

\subsubsection{Measuring Green Water Scarcity versus Overall Green-Blue Water Scarcity}

In Sections 4.3.2.1 and 4.3.2.2 we mentioned a few indicators that measure overall greenblue water scarcity (Rockström et al., 2009; Gerten et al., 2011; Kummu et al., 2014). Whereas useful for getting an overall picture of water scarcity, a disadvantage of these indicators is that a high degree of green water scarcity can be masked by a low degree of blue water scarcity and vice versa. Imagine for example a river basin where nearly all land is in use and natural forest is under pressure by conversion to cropland (high degree of green water scarcity), while there is enough blue water available to irrigate 
croplands if necessary (low degree of blue water scarcity). Measuring increasing green water scarcity could be relevant, for instance, for the Amazon basin in South America, where increasingly natural forest and associated green water flows are turned into use and competition is essentially about land and associated green water resources, while blue water resources are abundant and blue water scarcity is low. Therefore, for studying green water scarcity, an indicator specifically comparing green water demand and green water availability can be more appropriate.

\subsection{Conclusions and Future Research}

In this paper we have reviewed and classified around 80 indicators of green water availability and scarcity. This list of indicators is extensive, but not exhaustive. Nevertheless, we are confident to have identified the most widely used and cited indicators.

The number of green water availability indicators by far outnumbers the existing green water scarcity indicators. This reflects that the concept of green water scarcity is still largely unexplored. Indicators of overall green-blue water crowding and scarcity have been developed by Rockström et al. (2009), Gerten et al. (2011) and Kummu et al. (2014). These have potential to be tailored to measure green water crowding and green water requirements for self-sufficiency versus green water availability. The green water scarcity indicator by Hoekstra et al. (2011) measures actual green water consumption versus green water availability, but has not yet been operationalized due to several challenges discussed in Section 4.3.2.4. The biggest challenge is to determine which part of the green water flow can be made productive in space and time. Application of both absolute and relative green water availability indicators will provide insight into where the green water flow can be made productive for human purposes. Simulations with crop growth models for different management strategies can be used to assess during which parts of the year the green water flow can be made productive.

Future research should be aimed at overcoming these challenges to make the green water scarcity indicators discussed in this paper operational. We also encourage the development of additional definitions of green water scarcity indicators to the ones discussed here. The conceptual definition of green water scarcity we introduced in Section 4.3 .2 can be a starting point for this.

Despite scientific obstacles on the way, it is time that the scope of water scarcity assessments is broadened to include green water. We hope that this paper is a stepping stone towards this goal by bringing structure in the large pool of green water availability 
indicators and discussing the way forward to develop operational green water scarcity indicators. Practitioners and scholars might also find the classification of indicators provided in this paper insightful and helpful for choosing the indicator that suits their purpose. 


\title{
5. The Water Footprint of Wood for Lumber, Pulp, Paper, Fuel and Firewood ${ }^{5}$
}

\begin{abstract}
This paper presents the first estimate of global water use in the forestry sector related to roundwood production for lumber, pulp, paper, fuel and firewood. For the period 19612010, we estimate forest evaporation at a high spatial resolution level and attribute total water consumption to various forest products, including ecosystem services. Global water consumption for roundwood production increased by $25 \%$ over 50 years to $961 \times 10^{9} \mathrm{~m}^{3} / \mathrm{y}$ (96\% green; $4 \%$ blue) in 2001-2010. The water footprint per $\mathrm{m}^{3}$ of wood is significantly smaller in (sub)tropical forests compared to temperate/boreal forests, because (sub)tropical forests host relatively more value next to wood production in the form of other ecosystem services. In terms of economic water productivity and energy yield from bio-ethanol per unit of water, roundwood is rather comparable with major food, feed and energy crops. Recycling of wood products could effectively reduce the water footprint of the forestry sector, thereby leaving more water available for the generation of other ecosystem services. Intensification of wood production can only reduce the water footprint per unit of wood if the additional wood value per ha outweighs the loss of value of other ecosystem services, which is often not the case in (sub)tropical forests. The results of this study contribute to a more complete picture of the human appropriation of water, thus feeding the debate on water for food or feed versus energy and wood.
\end{abstract}

\subsection{Introduction}

Although precipitation is renewable, it is limited in time and space, and so are its subsequent pathways as green and blue water flows (Schyns et al., 2015; Hoekstra, 2013). There are alternative competing uses for these limited flows, which makes freshwater a scarce resource. This explains the interest in the human appropriation of water (Postel et al., 1996; Rockström et al., 1999; Rockström \& Gordon, 2001; Hoekstra \& Mekonnen, 2012) in relation to a maximum sustainable level (Hoekstra \& Wiedmann, 2014) or planetary boundary (Steffen et al., 2015; Rockstrom et al., 2009). Freshwater sustains terrestrial and aquatic ecosystems and is used for the production of goods and services. Important water consuming sectors are agriculture, industries, municipalities and

${ }^{5}$ This chapter has been published as:

Schyns, J.F., Booij, M.J. \& Hoekstra, A.Y. (2017) The water footprint of wood for lumber, pulp, paper, fuel and firewood, Advances in Water Resources, 107: 490-501. 
forestry. Multiple studies have quantified the global blue and green water consumption for producing crop and livestock products, and for fulfilling industrial and municipal demands (Rost et al., 2008; Hanasaki et al., 2010; Liu \& Yang, 2010; Liu et al., 2009; Siebert \& Döll, 2010; Mekonnen \& Hoekstra, 2011a; Wada et al., 2014; Hoekstra \& Mekonnen, 2012; Döll et al., 2012). As recently identified by Vanham (2016), we do not know how much water is used in the forestry sector for the production of wood products such as lumber, pulp and paper, firewood or biofuel.

Forest evaporation accounts for $45-58 \%$ of the total vapour flow from land to atmosphere (Oki \& Kanae, 2006; Rockström et al., 1999; Rockström \& Gordon, 2001). With the term evaporation we refer to the entire vapour flux from land to atmosphere, including evaporation through the process of plant transpiration (Savenije, 2004). Determining which part of the evaporation is appropriated for the production of roundwood (wood in the rough) is not as straightforward as it is for crops. For crops, all evaporation from the crop field during the growing season is usually attributed to crop production. This makes sense, since crop fields are generally used quite intensively for a distinct purpose (providing food, feed or fibre). Forests on the other hand provide numerous other ecosystem services next to the provision of wood (Costanza et al., 1997), depending on the intensity of forest exploitation. Therefore, forest evaporation is to be attributed to roundwood production based on the relative value of roundwood production compared to the value of other ecosystem services provided by the forest.

There are a few studies that have attributed forest evaporation to wood products. Van Oel \& Hoekstra (2012) made a first estimate of the water footprint of paper in the main pulp producing countries. Chiu \& Wu (2013) estimated the water footprint of ethanol from wood residues from the southeast United States. Tian \& Ke (2012) made estimates of the water footprint of lumber, panels, pulp and paper in China. However, these studies did not account for the value of wood production relative to other forest values (Van Oel \& Hoekstra, 2012; Chiu \& Wu, 2013; Tian \& Ke, 2012). Launiainen et al. (2014) argue that one should not attribute forest evaporation of rain-fed managed forests to end products at all, based on the argument that the evaporation of these forests is not significantly different than that of natural forests (no net difference). However, for the purpose of measuring the amount of evaporation that is appropriated by roundwood production and therefore not available for other uses we should measure total (not net) water consumption (Hoekstra, 2017).

The objective of this paper is to provide the first estimate of the global water consumption related to roundwood production and to subsequently attribute this to 
various end-uses of wood. Our analysis is at high spatial resolution (30 x 30 arc minute) for the period 1961-2010 and includes a number of innovations:

- Global high-resolution estimates of actual evaporation from production forests, distinguishing the contribution of green water (precipitation) and blue water (groundwater through capillary rise).

- Attribution of forest evaporation to roundwood production based on the relative value of roundwood production compared to the value of other ecosystem services provided by the forest.

- Estimates of the green and blue water footprints of wood products, including sawnwood, wood-based panels, wood pulp, paper and wood-based energy carriers.

\subsection{Method and Data}

We follow the method of water footprint assessment to estimate the water consumption associated with roundwood production for lumber, pulp, paper, fuel and firewood (Hoekstra et al., 2011). Firstly, we estimate the volume of water consumed that can be attributed to roundwood production per $30 \times 30$ arc minute grid cell per year over the period 1961-2010 (Section 5.2.1). Secondly, we estimate the period-average water footprint per unit of roundwood produced (Section 5.2.2). Finally, we attribute the water footprint of roundwood production to various end-uses of wood (Section 5.2.3). Throughout this paper we use the term water footprint to refer to the consumptive part only (green plus blue) and exclude the grey component that expresses water pollution.

\subsubsection{Water Consumption Attributed to Roundwood Production}

The volume of water consumed that can be attributed to roundwood production $(W U$, in $\mathrm{m}^{3} / \mathrm{y}$ ) in grid cell $x$ in year $t$ is estimated as:

$$
W U[x, t]=\left(E_{\text {act }}[x, t] \times A_{\mathrm{rw}}[x, t]+P_{\mathrm{act}}[x, t] \times f_{\text {water }}[x]\right) \times f_{\text {value,rw }}[x, t]
$$

in which Eact is the actual forest evaporation $(\mathrm{m} / \mathrm{y}), A_{\mathrm{rw}}$ the area used for roundwood production $\left(\mathrm{m}^{2}\right)$, Pact the actual roundwood harvested $\left(\mathrm{m}^{3} / \mathrm{y}\right), f_{\text {water }}$ the volumetric moisture content of freshly harvested wood $\left(\mathrm{m}^{3}\right.$ water $/ \mathrm{m}^{3}$ wood), and $f_{\text {value, } \mathrm{rw}}$ a dimensionless fraction that represents the relative value of roundwood production compared to the value of other ecosystem services provided by the forest.

\section{Annual Actual Forest Evaporation}

$E_{\text {act }}(\mathrm{m} / \mathrm{y})$ is estimated using the method of Zhang et al. (2001): 


$$
E_{\mathrm{act}}[x, t]=\operatorname{Pr}[x, t]\left(\frac{1+w \frac{E_{0}[x, t]}{\operatorname{Pr}[x, t]}}{1+w \frac{E_{0}[x, t]}{\operatorname{Pr}[x, t]}+\frac{\operatorname{Pr}[x, t]}{E_{0}[x, t]}}\right)
$$

in which $\operatorname{Pr}$ is the annual precipitation $(\mathrm{m} / \mathrm{y}), w$ a dimensionless coefficient representing plant water availability, and $E_{0}$ the annual potential forest evaporation (m/y). We apply a $w$ of 2 , which is the best fit value for forests based on a study that includes 56 forest catchments around the world (Zhang et al., 1999). We determine Eo based on the mean annual temperature $\left(T\right.$, in $\left.{ }^{0} \mathrm{C}\right)$ using the empirical equation derived by Komatsu et al. (2012), which they derived for Zhang's equation by regressing 829 forest Eact data points:

$$
E_{0}[x, t]=\left(0.488 T^{2}[x, t]+27.5 T[x, t]+412\right) \times 10^{-3}
$$

The factor $10^{-3}$ is to convert $\mathrm{mm}$ to $\mathrm{m}$.

\section{Distinction Between Green and Blue Water Use}

The distinction between green and blue water use is made by applying a fraction that represents the part of water use that originates from capillary rise $\left(f_{\text {blue}}\right)$ :

$$
\begin{aligned}
& W U_{\text {green }}[x, t]=W U[x, t] \times\left(1-f_{\text {blue }}[x, t]\right) \\
& W U_{\text {blue }}[x, t]=W U[x, t] \times f_{\text {blue }}[x, t]
\end{aligned}
$$

We estimate folue based on two main assumptions:

- Capillary rise is at its maximum in a very dry year $\left(E_{\text {act }} / \mathrm{Pr}=1\right)$ and moves linearly to zero in an extremely wet year $\left(E_{\text {act }} / \mathrm{Pr}=0\right)$. A water potential gradient is required to move water upward from the groundwater table. When the soil is dry this gradient is strong. If the soil is saturated this gradient is absent and there will be no capillary rise.

- The distance that needs to be bridged by capillary rise ( $d_{c a p}$, in $\mathrm{m}$ ) is defined as the difference between the groundwater table depth $\left(z_{\mathrm{g}}\right)$ and the root depth of the forest type $(z \mathrm{r})$, both in $\mathrm{m}$ below a certain reference level. The maximum height of capillary rise ( $d_{\text {cap,max, }}$ in $\mathrm{m}$ ) depends on the soil type. When $d_{\text {cap }}$ is nonlimiting $(\leq 0)$, the roots take up a share $d_{c a p, \max }$ of $\mathrm{zr}$ through capillary rise under very dry conditions. This share decreases linearly to zero when $d_{\text {cap }}$ approaches $d_{\text {cap,max }}$ (beyond, there is no capillary uptake at all). 
These assumptions can be combined into a single equation that applies when $0 \leq d_{\text {cap }}<$ $d_{\text {cap, max: }}$

$$
f_{\text {blue }}[x, t]=\frac{d_{\text {cap, } \max }[x]}{z_{\mathrm{r}}[x]} \frac{E_{\mathrm{act}}[x, t]}{\operatorname{Pr}[x, t]}\left(1-\frac{z_{\mathrm{g}}[x]-z_{\mathrm{r}}[x]}{d_{\text {cap } \max }[x]}\right)
$$

\subsubsection{Water Footprint per Unit of Roundwood Production}

Since wood production cycles are commonly multi-decadal (Bauhus et al., 2009), we calculate the water footprint per unit of production as a period-average. The water footprint of roundwood production ( $W F_{\mathrm{rw}}$, in $\mathrm{m}^{3}$ water $/ \mathrm{m}^{3}$ roundwood) for the period of $m$ years is defined as:

$$
W F_{\mathrm{rw}}[x]=\frac{\sum_{t=1}^{m} W U[x]}{\sum_{t=1}^{m} P_{\mathrm{act}}[x]}
$$

\subsubsection{Water Footprint per Unit of End Product}

The water footprint per unit of end product $p$ produced with roundwood from grid cell $x$ is estimated by multiplying $W F_{\mathrm{rw}}$ with a conversion factor ( $f_{\text {conversion, in }} \mathrm{m}^{3}$ roundwood/unit of end product):

$$
W F_{\mathrm{p}}[p, x]=W F_{\mathrm{rw}}[x] \times f_{\text {conversion }}[p]
$$

\subsubsection{Wood Harvested Area}

We obtained wood harvested area maps (as fraction of a grid cell) at $30 \times 30$ arc minute resolution for each year in the period 1961-2004 from Chini et al. (2014). For 2005-2010, we keep the pattern from 2004. Hurtt et al. (2011) estimated the wood harvest pattern with a global land-use model that takes, among others, national wood harvest data as input, constrains wood harvesting by the presence of forests, and gives preference to wood harvesting near existing land-use (proximity to infrastructure or local markets). We took the sum of the five different land types from which wood can be harvested as distinguished by Hurtt et al. (2011).

We apply three restrictions to these maps. Firstly, we assumed that roundwood production only takes place in those grid cells that have a forest cover according to the IGBP DISCover land cover database (Loveland et al., 2009). Secondly, we consider grid cells with an average Eact ver the study period of less than $100 \mathrm{~mm} / \mathrm{y}$ to be unsuitable for 
forest growth that enables wood harvesting and hence remove those grid cells from our final map. This threshold is derived from Komatsu et al. (2012), who collected 829 forest Eact data points at locations spread over the world, of which only three $(0.4 \%)$ have an Eact smaller than $100 \mathrm{~mm} / \mathrm{y}$. Thirdly, we assumed that no wood is harvested from grid cells that are entirely located within a protected area of IUCN category Ia (strict nature reserves), Ib (wilderness areas) or II (national parks) from the year that these areas received this status. The data on protected areas have been obtained from IUCN \& UNEP-WCMC (2016).

We made one exception to the above procedure. The People's Democratic Republic of Ethiopia (1961-1992) had a significant contribution to world roundwood production according to national statistics (FAO, 2016b). However, the cells where wood harvesting took place in this country according to the map by Chini et al. (2014) have no forest cover according to the IGBP DISCover dataset. To avoid neglect of this roundwood production, we assigned the most common forest type in the region to the cells where wood was harvested: tropical evergreen broadleaf forest. Finally, we scale the wood harvested area maps on the national level to the area used for roundwood production estimated based on the Global Forest Resources Assessment 2015 (Köhl et al., 2015) (see Appendix C.1).

\subsubsection{Actual Roundwood Production at the Grid Level}

National annual statistics on actual roundwood production from coniferous $(C)$ and nonconiferous (NC) forest covering the study period have been obtained from FAO (2016b). We downscale these data to the grid level in two steps. Firstly, we estimate the maximum sustainable production in a grid cell by multiplying the wood harvested area with a long-term maximum sustainable wood yield (Section 5.2.6). Therein, we distinguish between $\mathrm{C}$ and NC production by assuming that $\mathrm{C}$ wood is produced in needleleaf forests and NC wood in broadleaf forests and that mixed forest contributes to both $\mathrm{C}$ and NC production (fifty-fifty). For a small number of countries, in some years, reported production concerns C and/or NC wood, while our maps contain no grid cells yielding that type of wood (e.g. only NC production is reported, but all grid cells in the wood harvest map are of the needleleaf type). In these cases, we overwrite the dominant forest type in all affected grid cells for that year to mixed forest. Secondly, we distribute the national annual statistics over all grid cells used for roundwood production in that year, according to the estimated maximum sustainable production for that roundwood type (C or NC). 


\subsubsection{Long-Term Maximum Sustainable Wood Yield}

The rate of wood production varies over the age of the forest stand following an sshaped curve that is different for each species, location and type of management (Lutz, 2011). he mean annual increment is the average production rate at any particular age of the forest, calculated as the total growing stock volume divided by the age of the forest stand (Jürgensen et al., 2014; Lutz, 2011; Blanchez, 1997). We obtained minimum and maximum forest plantation yields (in $\mathrm{m}^{3} / \mathrm{ha} / \mathrm{y}$ ) for different tree species in various countries around the world from Brown (2000). These yields represent the mean annual increment for the likely rotation length of the forest stand. We assume that forests are of a mixed age, that trees are harvested at their likely rotation length and that natural losses are minimal. Under these circumstances, we consider the yields by Brown (2000) to be a good proxy of the long-term maximum sustainable wood yield $\left(Y_{\text {sus }}\right)$.

Ultimately, we need an estimate of $Y_{\text {sus }}$ for each grid cell in our roundwood production maps. To arrive there, (i) we determine the dominant forest type and climate zone of each grid cell; (ii) we assume characteristic tree species for each forest type; (iii) we determine the dominant climate zone in each country in the dataset by Brown (2000); (iv) from this dataset we calculate the average $Y_{\text {sus }}$ of a tree species per climate zone and (v) we assign those $Y_{\text {sus }}$ estimates to the grid cells. Details are described in Appendix C.2-3. The following assumptions are made under (ii), which are loosely based on the forest type descriptions of Matthews et al. (2000):

- Evergreen needleleaf forest yields pine (Pinus species) in all climate zones.

- Evergreen broadleaf forest yields eucalyptus (Eucalyptus species) in all climate zones.

- Deciduous needleleaf forest yields larch (Larix species) in all climate zones.

- Deciduous broadleaf forest yields oak (Quercus species) in all climate zones.

- Mixed forest in the tropical and subtropical zone yields a 50-50 mix of pine and eucalyptus.

- $\quad$ Mixed forest in the temperate zone yields a 50-50 mix of pine and oak.

- Mixed forest in the boreal zone yields a 50-50 mix of pine and larch.

The resulting $Y_{\text {sus }}$ estimates per forest type and climate zone are presented in Table 5-1. The climate zones and forest types are mapped in Figure 5-1. 
Table 5-1. Long-term maximum sustainable yield per forest type and climate zone (in $\mathrm{m}^{3} / \mathrm{ha} / \mathrm{y}$ ). Data estimated based on Brown (2000). Not each forest type is present in each climate zone as indicated with a hyphen.

\begin{tabular}{|c|c|c|c|c|c|}
\hline Climate zone & $\begin{array}{l}\text { Evergreen } \\
\text { needleleaf } \\
\text { (pine) }\end{array}$ & $\begin{array}{l}\text { Evergreen } \\
\text { broadleaf } \\
\text { (eucalyptus) }\end{array}$ & $\begin{array}{l}\text { Deciduous } \\
\text { needleleaf } \\
\text { (larch) }\end{array}$ & $\begin{array}{l}\text { Deciduous } \\
\text { broadleaf } \\
\text { (oak) }\end{array}$ & Mixed \\
\hline Tropics & 13.5 & 9 & - & 9 & 11.5 \\
\hline $\begin{array}{l}\text { Subtropics, summer } \\
\text { rainfall }\end{array}$ & 13.5 & 11.5 & 12 & 11.5 & 12.5 \\
\hline $\begin{array}{l}\text { Subtropics, winter } \\
\text { rainfall }\end{array}$ & 8 & 10 & 12 & 5 & 9 \\
\hline Temperate & 7 & - & 8 & 5 & 6 \\
\hline $\begin{array}{l}\text { Boreal, oceanic \& } \\
\text { sub-continental }\end{array}$ & 6 & - & 4 & - & 5 \\
\hline $\begin{array}{l}\text { Boreal, continental } \\
\& \text { arctic }\end{array}$ & 3 & - & 4 & - & 3.5 \\
\hline
\end{tabular}

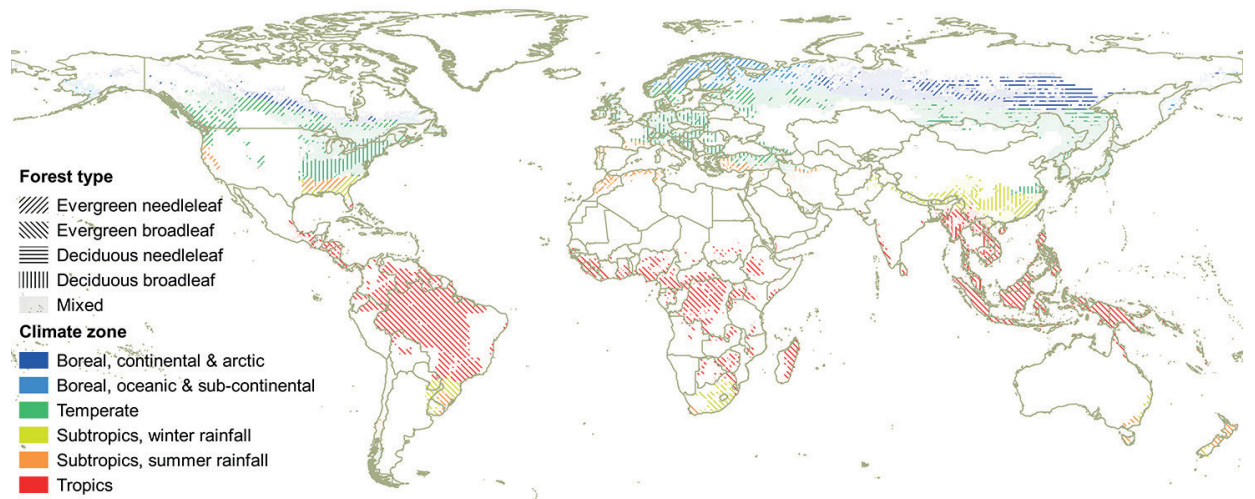

Figure 5-1. Forest types and climate zones for the grid cells where roundwood is produced. Data obtained from Loveland et al. (2009) and Van Velthuizen et al. (2007) as described in Appendix C.2. 
Table 5-2. Rooting depth (m). Data derived from Canadell et al. (1996).

\begin{tabular}{|lccr|}
\hline Climate zone & Evergreen & Deciduous & Mixed \\
\hline Tropics \& subtropics, summer rainfall & 7 & 4 & 5.5 \\
Subtropics, winter rainfall a & 5 & 5 & 5 \\
Temperate & 4 & 3 & 3.5 \\
Boreal \& arctic & 2 & 2 & 2 \\
\hline
\end{tabular}

a Values for sclerophyllous forest

\subsubsection{Meteorological Data}

For each 30 × 30 arc minute grid cell and each year in our study period, we estimated the annual precipitation $(\mathrm{Pr})$ and annual mean temperature $(T)$ based on daily data obtained from De Graaf et al. (2014).

\subsubsection{Fraction of Water Use Originating from Capillary Rise}

Rooting depths were derived from Canadell et al. (1996) (Table 5-2). The groundwater table depth per $30 \times 30$ arc minute grid cell has been estimated by averaging over the 30 x 30 arc second map by Fan et al. (2013). The maximum height of capillary rise is estimated using an empirical relation based on the soil's grain size and void ratio (details in Appendix C.4).

\subsubsection{Volumetric Moisture Content of Freshly Harvested Wood}

The fraction $f_{\text {water }}$ is estimated by multiplying a species wood density with the equilibrium moisture content ( $t$ water/t oven dried wood) (derivation in Appendix C.5). The wood density for each of the characteristic tree species considered in this study has been estimated from Zanne et al. (2009) (Table 5-3). The equilibrium moisture content is estimated per grid cell for each year with the function of Simpson (1998) that takes temperature and relative humidity as inputs. We applied the mean annual temperature (Section 5.2.7) and a climate-average relative humidity per grid cell. The latter is estimated based on the $10 \times 10$ arc minute gridded monthly mean relative humidity data for 1961-1990 from New et al. (2002). We took the average of all months and subsequently the average of all $10 \times 10$ arc minute grid cells within a $30 \times 30$ arc minute grid cell. 
Table 5-3. Wood densities of the characteristic tree species considered in this study. Data from Zanne et al. (2009) as described in Chave et al. (2009). Data represent the average of all entries for a species.

\begin{tabular}{|lc|}
\hline Species & Wood density $\left(\mathrm{t} / \mathrm{m}^{3}\right)$ \\
\hline Pinus (Pine) & 0.4 \\
Eucalyptus (Eucalyptus) & 0.8 \\
Larix (Larch) & 0.5 \\
Quercus (Oak) & 0.7 \\
\hline
\end{tabular}

\subsubsection{Value Fraction of Roundwood Production}

We base our estimate of the value fraction of roundwood production $\left(f_{\text {value,rw }}\right)$ on Costanza et al. (2014), who estimated the value of 17 ecosystems services (in monetary units/ha) around the year 2011 for (sub)tropical forests and temperate/boreal forests, separately (Figure 5-2). We assume that the service labelled 'raw materials' by Costanza et al. (2014) primarily refers to roundwood production. Non-wood forest products that are not of interest for this study are included under other services, e.g. food and food additives ('food production') and plant and animal parts for pharmaceutical products ('genetic resources').

The data in Figure 5-2 refer to the entire forest biomes, while we are interested in production forests specifically. Therefore, we first distribute the monetary values per hectare of the services over production and non-production forests for the reference year 2010 (which lies closest to the reporting year by (Costanza et al., 2014)). Secondly, we scale the values back in time and disaggregate them spatially over the grid cells. Therein, we distinguish three categories of ecosystem service values:

- The value of roundwood production that varies with the volume of roundwood produced.

- The value of the services pollination, biological control, habitat/refugia, recreation and culture that are inversely proportional to the intensity of forest exploitation, which is defined as the actual wood production over the maximum sustainable wood production.

- The value of the other services given in Figure 5-2 that are invariable with the intensity of forest exploitation. 

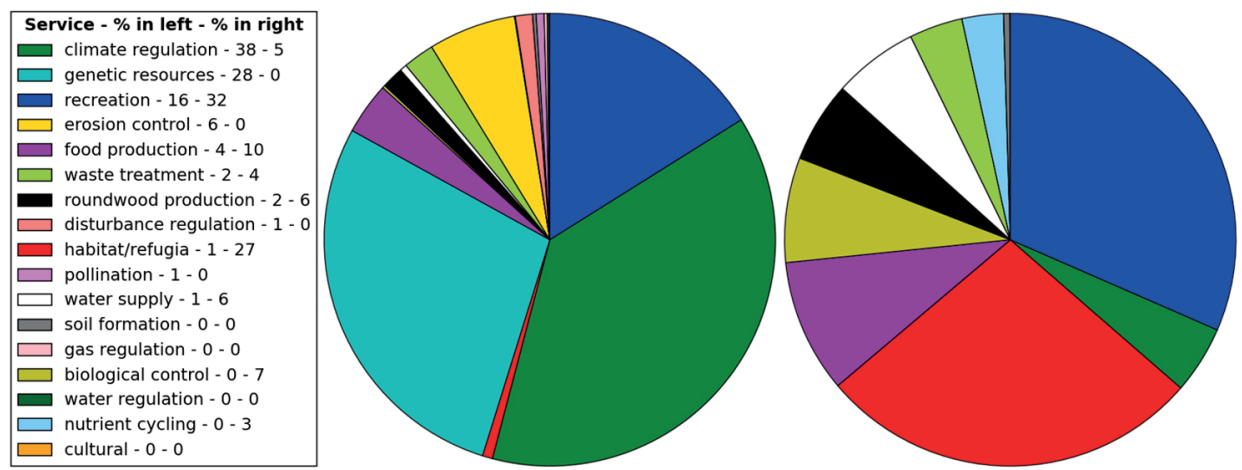

Figure 5-2. The relative value of ecosystems services for tropical (left) and temperate/boreal forests (right). Data source: Costanza et al. (2014). Descriptions of the ecosystem services can be found in Costanza et al. (1997).

For the year 2010, and averaged per biome, the resulting ecosystem service values are consistent with those reported in Figure 5-2. Details and assumptions are described in Appendix C.6. Ultimately, we calculate $f_{\text {value,rw }}$ per grid cell per year using Equation C-10 (Appendix C.6).

\subsubsection{Wood to End Product Conversion Factors}

Conversion factors for sawnwood, panels, pulp, paper and energy wood products are obtained from UNECE/FAO (2010) and represent averages of reported values by countries in the UNECE region. The energy values represent higher heating values (HHV). Some additional data on the HHV of softwood, hardwood, ethanol and charcoal are obtained from (Speight, 2010). The water footprint of an A4 $\left(=1 / 16 \mathrm{~m}^{2}\right)$ sheet of paper of $80 \mathrm{~g} / \mathrm{m}^{2}$ in $1 /$ sheet is estimated by multiplying the water footprint of paper in $\mathrm{m}^{3} / \mathrm{t}$ with a factor $0.005(=80 / 16 / 1000)$.

\subsection{Results}

\subsubsection{Water Consumption Attributed to Roundwood Production}

The global water consumption attributed to roundwood production increased by $25 \%$ over 50 years, from $768 \times 10^{9} \mathrm{~m}^{3} / \mathrm{y}$ in $1961-1970$ to $961 \times 10^{9} \mathrm{~m}^{3} / \mathrm{y}$ in 2001-2010 (for both decades: $96 \%$ green; $4 \%$ blue). The water consumption equals the evaporated volume attributed to roundwood production, since the share of the water incorporated in the harvested wood is negligible $(0.01 \%$ on average). 

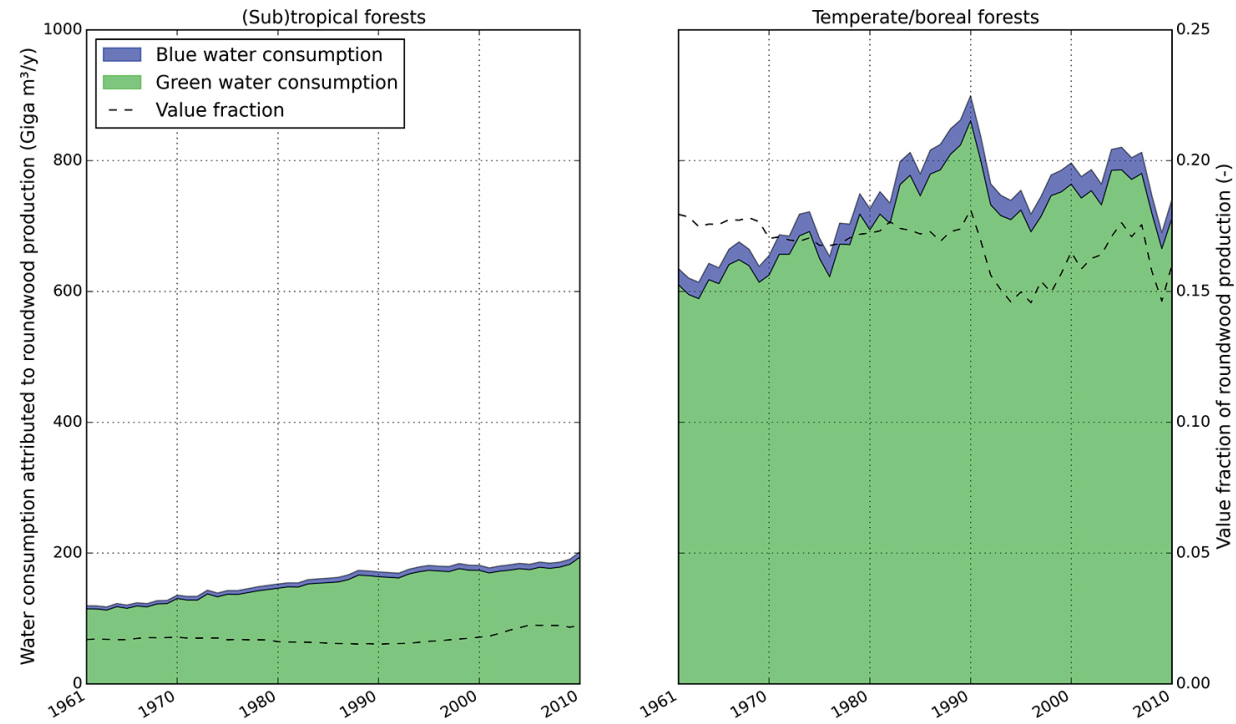

Figure 5-3. Water consumption attributed to roundwood production. Period: 1961-2010.

Figure 5-3 shows the water consumption attributed to roundwood production $(W U)$ and the value fraction of roundwood production $\left(f_{\text {value,rw }}\right)$ in the biomes (sub)tropical forests and temperate and boreal forests, separately. WU is significantly smaller in the former compared to the latter caused by the difference in $f_{\text {value,rw }}$ for those biomes (Figure 5-2 and Appendix C.7). For (sub)tropical forests, an increasing trend in WU is observed, driven by increases in the area used for roundwood production and the volume of roundwood produced (see Figure C-2, Appendix C.7). For temperate and boreal forests, a moderate increasing trend in WU is visible due to an increased area used for roundwood production. Inter-annual variation is larger in this case. Variation in WU is caused by

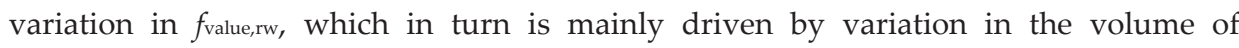
roundwood produced (Figure C-2, Appendix C.7). The latter explains the sudden decline in $f_{\text {value,rw }}$ and $W U$ after 1990 when the statistics (FAO, 2016b) show a drop in roundwood production (in the former USSR). In both forest biomes, varying forest evaporation rates add to the temporal variation in $W U$ (Figure C-2, Appendix C.7).

\subsubsection{Water Footprint per Unit of Roundwood Production}

The study period average water footprint per unit of roundwood production ( $\left.W F_{\mathrm{rw}}\right)$ is presented in Figure 5-4. Besides the differences between the (sub)tropical and temperate/boreal zones (Section 5.3.1), spatial variation in $W F_{\mathrm{rw}}$ is mostly explained by varying forest evaporation rates (Table C-2, Appendix C.8). 


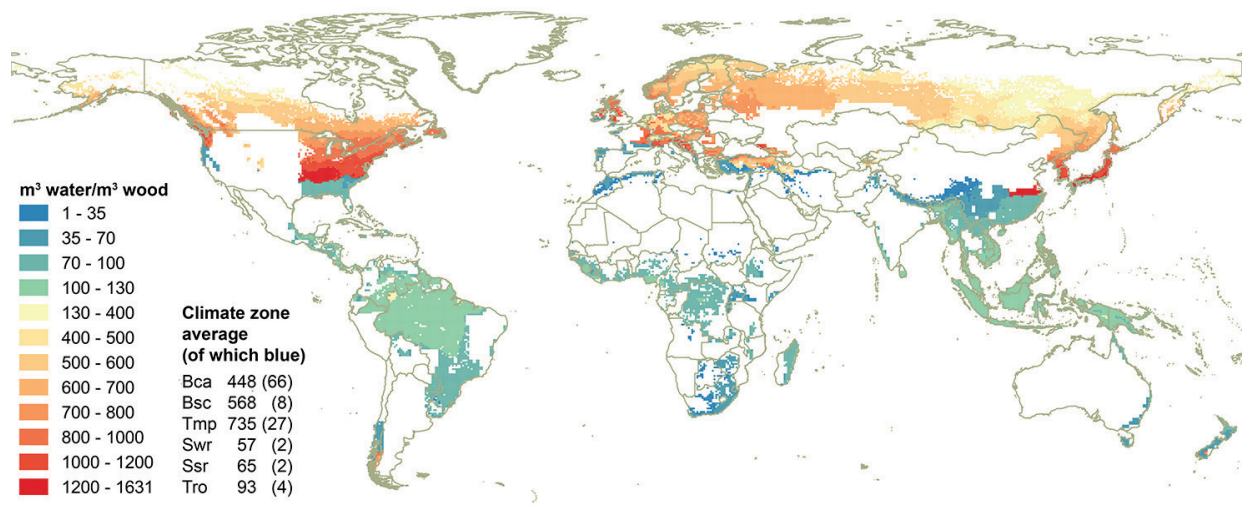

Figure 5-4. The water footprint per unit of roundwood production $\left(\mathrm{m}^{3}\right.$ water $/ \mathrm{m}^{3}$ roundwood) at $30 \times 30$ arc minute resolution. The table next to the legend shows the average (production-weighted) water footprint per climate zone: boreal, continental \& arctic (Bca); boreal, oceanic \& sub-continental (Bsc); temperate (Tmp); subtropics, winter rainfall (Swr); subtropics, summer rainfall (Ssr); tropics (Tro). Period: 1961-2010. Note that not all grid cells were necessarily used for roundwood production in each year.

The decade average $W F_{\mathrm{rw}}$ increased with about ten percent over the study period in temperate and boreal zones, while it varied within five percent in the (sub)tropics.

The average capillary rise contribution to $W F_{\mathrm{rw}}$ is mapped in Figure 5-5. The areas with a capillary rise contribution of more than $50 \%$ are mostly found in Russia and Canada. Blue water constitutes a significant part of the total water consumption attributed to roundwood production in countries like the Bahamas (32\%), Gambia (28\%), the Netherlands $(24 \%)$ and Somalia (23\%). Variations in the capillary rise contribution are mainly explained by the groundwater depth. Miller et al. (2010) found for a semi-arid oak savanna in the period 2005-2008 (average $E_{\text {act }} / \mathrm{Pr}$ ratio of 0.7), that the average contribution of capillary rise to the evaporation over the year was about $22 \%$. For grid cells with a capillary rise contribution to evaporation and an $E_{\text {act }} / \mathrm{Pr}$ ratio of at least 0.7, we found this contribution to be $18 \%$ on average. 


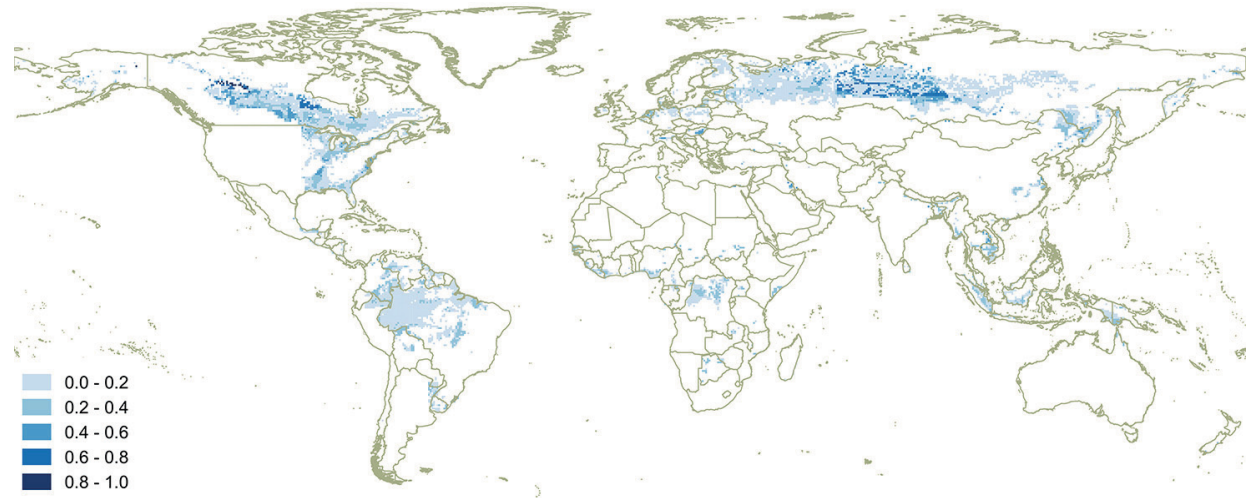

Figure 5-5. The average capillary rise contribution as a fraction of the forest water consumption (fblue). Resolution: 30 x 30 arc minute. Period: 1961-2010.

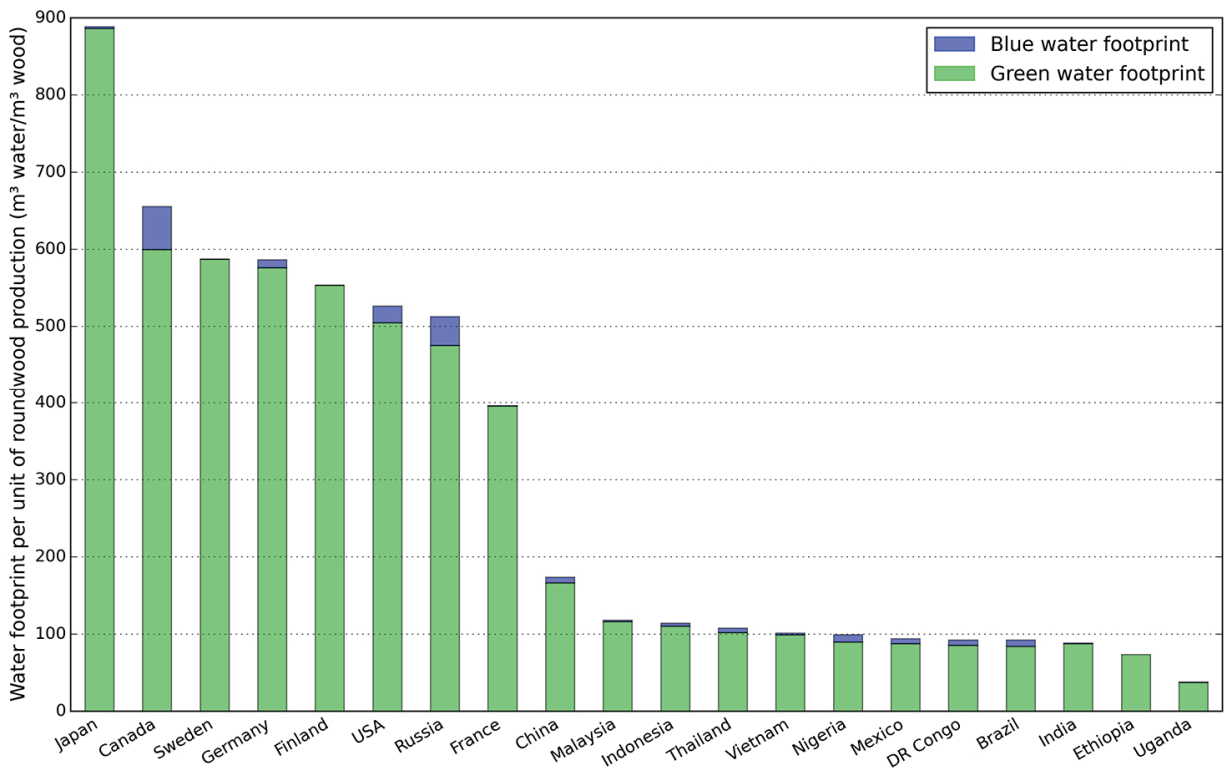

Figure 5-6. The average (production-weighted) water footprint per unit of roundwood production $\left(\mathrm{m}^{3}\right.$ water $/ \mathrm{m}^{3}$ roundwood) for the main roundwood producing countries. Period: 1961-2010.

Figure 5-6 shows the average $W F_{\mathrm{rw}}$ for each of the main roundwood producing countries. There is a clear distinction between countries with production forests in mainly (sub)tropical versus temperate/boreal zones. Among the main roundwood producing countries, Japan has on average the largest $W F_{\mathrm{rw}}$, resulting from a combination of a relatively high forest evaporation rate with a relatively low wood yield. 
Although pronounced spatial variations in $W F_{\text {rw }}$ occur, one should be cautious in evaluating these differences in terms of better or worse. The relevance of the data presented rather lies in the fact that they can form a basis for further study into the alternative uses of the same water to produce more or different goods and services in the same area (see Section 5.4.3).

\subsubsection{Water Footprint per Unit of End Product}

The water footprints of various end products derived from roundwood, based on global averages, are given in Table 5-4. The values vary depending on the origin of the roundwood, since the water footprint per cubic metre of roundwood produced varies around the globe (Figure 5-4). The global average water footprint of one A4 sheet $80 \mathrm{~g}$ printing and writing paper is 5.11 and ranges from $1.0 \mathrm{l} /$ sheet in the subtropics with summer rainfall to $12.9 \mathrm{l} /$ sheet in the temperate zone.

Table 5-4. The water footprint of various end products derived from roundwood (rw) in $\mathrm{m}^{3}$ water per unit of end product. Based on global average water footprint of roundwood weighted by production: $390 \mathrm{~m}^{3} / \mathrm{m}^{3}$ coniferous $\mathrm{rw} ; 231 \mathrm{~m}^{3} / \mathrm{m}^{3}$ nonconiferous rw; $293 \mathrm{~m}^{3} / \mathrm{m}^{3}$ rw on average. Conversion factors are derived from UNECE/FAO (2010). Additional data sources required to determine the conversion factors for energy wood products are indicated in the Table notes.

\begin{tabular}{|c|c|c|c|c|}
\hline $\begin{array}{l}\text { FAO- } \\
\text { STA } \\
\text { code }\end{array}$ & Product name & $\begin{array}{l}\text { Wood } \\
\text { type }\end{array}$ & Conversion factor & Water footprint \\
\hline \multicolumn{5}{|c|}{ Sawnwood } \\
\hline 1632 & Sawnwood & coniferous & $1.86 \mathrm{~m}^{3} \mathrm{rw} / \mathrm{m}^{3}$ sawnwood & $726 \mathrm{~m}^{3} / \mathrm{m}^{3}$ sawnwood \\
\hline 1633 & Sawnwood & $\begin{array}{l}\text { non- } \\
\text { coniferous }\end{array}$ & $1.88 \mathrm{~m}^{3} \mathrm{rw} / \mathrm{m}^{3}$ sawnwood & $433 \mathrm{~m}^{3} / \mathrm{m}^{3}$ sawnwood \\
\hline \multicolumn{5}{|c|}{ Veneer and plywood } \\
\hline 1634 & Veneer sheets & - & $2.21 \mathrm{~m}^{3} \mathrm{rw} / \mathrm{m}^{3}$ sheets & $648 \mathrm{~m}^{3} / \mathrm{m}^{3}$ sheets \\
\hline 1634 & Veneer sheets & coniferous & $2.08 \mathrm{~m}^{3} \mathrm{rw} / \mathrm{m}^{3}$ sheets & $812 \mathrm{~m}^{3} / \mathrm{m}^{3}$ sheets \\
\hline 1634 & Veneer sheets & $\begin{array}{l}\text { non- } \\
\text { coniferous }\end{array}$ & $2.35 \mathrm{~m}^{3} \mathrm{rw} / \mathrm{m}^{3}$ sheets & $542 \mathrm{~m}^{3} / \mathrm{m}^{3}$ sheets \\
\hline 1640 & Plywood & - & $2.07 \mathrm{~m}^{3} \mathrm{rw} / \mathrm{m}^{3}$ panels & $607 \mathrm{~m}^{3} / \mathrm{m}^{3}$ panels \\
\hline 1640 & Plywood & coniferous & $2.01 \mathrm{~m}^{3} \mathrm{rw} / \mathrm{m}^{3}$ panels & $785 \mathrm{~m}^{3} / \mathrm{m}^{3}$ panels \\
\hline
\end{tabular}


Table 5-4 (continued). The water footprint of various end products derived from roundwood (rw) in $\mathrm{m}^{3}$ water per unit of end product.

\begin{tabular}{|c|c|c|c|c|}
\hline $\begin{array}{l}\text { FAO- } \\
\text { STA } \\
\text { code }\end{array}$ & Product name & $\begin{array}{l}\text { Wood } \\
\text { type }\end{array}$ & Conversion factor & Water footprint \\
\hline 1640 & Plywood & $\begin{array}{l}\text { non- } \\
\text { coniferous }\end{array}$ & $2.13 \mathrm{~m}^{3} \mathrm{rw} / \mathrm{m}^{3}$ panels & $491 \mathrm{~m}^{3} / \mathrm{m}^{3}$ panels \\
\hline \multicolumn{5}{|c|}{ Wood panels from wood particles a } \\
\hline 1646 & Particle board & - & $2.76 \mathrm{~m}^{3} \mathrm{rw} / \mathrm{m}^{3}$ panels & $809 \mathrm{~m}^{3} / \mathrm{m}^{3}$ panels \\
\hline 1646 & Particle board & coniferous & $2.64 \mathrm{~m}^{3} \mathrm{rw} / \mathrm{m}^{3}$ panels & $1031 \mathrm{~m}^{3} / \mathrm{m}^{3}$ panels \\
\hline 1646 & Particle board & $\begin{array}{l}\text { non- } \\
\text { coniferous }\end{array}$ & $2.87 \mathrm{~m}^{3} \mathrm{rw} / \mathrm{m}^{3}$ panels & $662 \mathrm{~m}^{3} / \mathrm{m}^{3}$ panels \\
\hline 1647 & Hardboard & - & $3.56 \mathrm{~m}^{3} \mathrm{rw} / \mathrm{m}^{3}$ panels & $1044 \mathrm{~m}^{3} / \mathrm{m}^{3}$ panels \\
\hline 1647 & Hardboard & coniferous & $3.41 \mathrm{~m}^{3} \mathrm{rw} / \mathrm{m}^{3}$ panels & $1331 \mathrm{~m}^{3} / \mathrm{m}^{3}$ panels \\
\hline 1647 & Hardboard & $\begin{array}{l}\text { non- } \\
\text { coniferous }\end{array}$ & $3.71 \mathrm{~m}^{3} \mathrm{rw} / \mathrm{m}^{3}$ panels & $855 \mathrm{~m}^{3} / \mathrm{m}^{3}$ panels \\
\hline 1648 & MDF & - & $2.95 \mathrm{~m}^{3} \mathrm{rw} / \mathrm{m}^{3}$ panels & $865 \mathrm{~m}^{3} / \mathrm{m}^{3}$ panels \\
\hline 1648 & MDF & coniferous & $2.82 \mathrm{~m}^{3} \mathrm{rw} / \mathrm{m}^{3}$ panels & $1101 \mathrm{~m}^{3} / \mathrm{m}^{3}$ panels \\
\hline 1648 & MDF & $\begin{array}{l}\text { non- } \\
\text { coniferous }\end{array}$ & $3.07 \mathrm{~m}^{3} \mathrm{rw} / \mathrm{m}^{3}$ panels & $708 \mathrm{~m}^{3} / \mathrm{m}^{3}$ panels \\
\hline 1650 & Insulating board & - & $1.46 \mathrm{~m}^{3} \mathrm{rw} / \mathrm{m}^{3}$ panels & $428 \mathrm{~m}^{3} / \mathrm{m}^{3}$ panels \\
\hline 1650 & Insulating board & coniferous & $1.39 \mathrm{~m}^{3} \mathrm{rw} / \mathrm{m}^{3}$ panels & $543 \mathrm{~m}^{3} / \mathrm{m}^{3}$ panels \\
\hline 1650 & Insulating board & $\begin{array}{l}\text { non- } \\
\text { coniferous }\end{array}$ & $1.52 \mathrm{~m}^{3} \mathrm{rw} / \mathrm{m}^{3}$ panels & $350 \mathrm{~m}^{3} / \mathrm{m}^{3}$ panels \\
\hline \multicolumn{5}{|c|}{ Wood pulp } \\
\hline 1654 & $\begin{array}{l}\text { Mechanical } \\
\text { wood pulp }\end{array}$ & - & $2.50 \mathrm{~m}^{3} \mathrm{rw} / \mathrm{t}$ pulp & $733 \mathrm{~m}^{3} / \mathrm{t}$ pulp \\
\hline 1655 & $\begin{array}{l}\text { Semi-chemical } \\
\text { wood pulp }\end{array}$ & - & $2.67 \mathrm{~m}^{3} \mathrm{rw} / \mathrm{t}$ pulp & $783 \mathrm{~m}^{3} / \mathrm{t}$ pulp \\
\hline 1656 & $\begin{array}{l}\text { Chemical wood } \\
\text { pulp }\end{array}$ & - & $4.49 \mathrm{~m}^{3} \mathrm{rw} / \mathrm{t}$ pulp & $1316 \mathrm{~m}^{3} / \mathrm{t}$ pulp \\
\hline
\end{tabular}


Table 5-4 (continued). The water footprint of various end products derived from roundwood (rw) in $\mathrm{m}^{3}$ water per unit of end product.

\begin{tabular}{|c|c|c|c|c|}
\hline $\begin{array}{l}\text { FAO- } \\
\text { STA } \\
\text { code }\end{array}$ & Product name & $\begin{array}{l}\text { Wood } \\
\text { type }\end{array}$ & Conversion factor & Water footprint \\
\hline 1660 & $\begin{array}{l}\text { Unbleached } \\
\text { sulphite pulp }\end{array}$ & - & $4.64 \mathrm{~m}^{3} \mathrm{rw} / \mathrm{t}$ pulp & $1360 \mathrm{~m}^{3} / \mathrm{t}$ pulp \\
\hline 1661 & $\begin{array}{l}\text { Bleached } \\
\text { sulphite pulp }\end{array}$ & - & $4.95 \mathrm{~m}^{3} \mathrm{rw} / \mathrm{t}$ pulp & $1451 \mathrm{~m}^{3} / \mathrm{t}$ pulp \\
\hline 1662 & $\begin{array}{l}\text { Unbleached } \\
\text { sulphate pulp }\end{array}$ & - & $4.45 \mathrm{~m}^{3} \mathrm{rw} / \mathrm{t}$ pulp & $1305 \mathrm{~m}^{3} / \mathrm{t}$ pulp \\
\hline 1663 & $\begin{array}{l}\text { Bleached } \\
\text { sulphate pulp }\end{array}$ & - & $4.55 \mathrm{~m}^{3} \mathrm{rw} / \mathrm{t}$ pulp & $1334 \mathrm{~m}^{3} / \mathrm{t}$ pulp \\
\hline 1667 & $\begin{array}{l}\text { Dissolving wood } \\
\text { pulp }\end{array}$ & - & $5.65 \mathrm{~m}^{3} \mathrm{rw} / \mathrm{t}$ pulp & $1656 \mathrm{~m}^{3} / \mathrm{t}$ pulp \\
\hline \multicolumn{5}{|c|}{ Paper and paperboard } \\
\hline 1612 & $\begin{array}{l}\text { Uncoated } \\
\text { mechanical }\end{array}$ & - & $3.32 \mathrm{~m}^{3} \mathrm{rw} / \mathrm{t}$ paper & $973 \mathrm{~m}^{3} / \mathrm{t}$ paper \\
\hline 1616 & Coated papers & - & $3.70 \mathrm{~m}^{3} \mathrm{rw} / \mathrm{t}$ paper & $1085 \mathrm{~m}^{3} / \mathrm{t}$ paper \\
\hline 1617 & Case materials & - & $3.88 \mathrm{~m}^{3} \mathrm{rw} / \mathrm{t}$ paper & $1137 \mathrm{~m}^{3} / \mathrm{t}$ paper \\
\hline 1618 & $\begin{array}{l}\text { Folding } \\
\text { boxboard }\end{array}$ & - & $3.75 \mathrm{~m}^{3} \mathrm{rw} / \mathrm{t}$ paper & $1099 \mathrm{~m}^{3} / \mathrm{t}$ paper \\
\hline 1621 & $\begin{array}{l}\text { Wrapping } \\
\text { papers }\end{array}$ & - & $3.82 \mathrm{~m}^{3} \mathrm{rw} / \mathrm{t}$ paper & $1120 \mathrm{~m}^{3} / \mathrm{t}$ paper \\
\hline 1622 & $\begin{array}{l}\text { Other papers } \\
\text { packaging }\end{array}$ & - & $3.75 \mathrm{~m}^{3} \mathrm{rw} / \mathrm{t}$ paper & $1099 \mathrm{~m}^{3} / \mathrm{t}$ paper \\
\hline 1671 & Newsprint & - & $2.87 \mathrm{~m}^{3} \mathrm{rw} / \mathrm{t}$ paper & $841 \mathrm{~m}^{3} / \mathrm{t}$ paper \\
\hline 1674 & $\begin{array}{l}\text { Printing + } \\
\text { writing paper }\end{array}$ & - & $3.51 \mathrm{~m}^{3} \mathrm{rw} / \mathrm{t}$ paper & $1029 \mathrm{~m}^{3} / \mathrm{t}$ paper \\
\hline 1675 & $\begin{array}{l}\text { Other paper }+ \\
\text { paperboard }\end{array}$ & - & $3.29 \mathrm{~m}^{3} \mathrm{rw} / \mathrm{t}$ paper & $965 \mathrm{~m}^{3} / \mathrm{t}$ paper \\
\hline
\end{tabular}


Table 5-4 (continued). The water footprint of various end products derived from roundwood (rw) in $\mathrm{m}^{3}$ water per unit of end product.

\begin{tabular}{|c|c|c|c|c|}
\hline $\begin{array}{l}\text { FAO- } \\
\text { STA } \\
\text { code }\end{array}$ & Product name & $\begin{array}{l}\text { Wood } \\
\text { type }\end{array}$ & Conversion factor & Water footprint \\
\hline 1676 & $\begin{array}{l}\text { Household }+ \\
\text { sanitary paper }\end{array}$ & - & $4.35 \mathrm{~m}^{3} \mathrm{rw} / \mathrm{t}$ paper & $1275 \mathrm{~m}^{3} / \mathrm{t}$ paper \\
\hline 1681 & $\begin{array}{l}\text { Wrapg + packg } \\
\text { paper + board }\end{array}$ & - & $3.25 \mathrm{~m}^{3} \mathrm{rw} / \mathrm{t}$ paper & $953 \mathrm{~m}^{3} / \mathrm{t}$ paper \\
\hline 1683 & $\begin{array}{l}\text { Paper }+ \\
\text { paperboard not } \\
\text { else specified }\end{array}$ & - & $3.29 \mathrm{~m}^{3} \mathrm{rw} / \mathrm{t}$ paper & $965 \mathrm{~m}^{3} / \mathrm{t}$ paper \\
\hline Energy & ood products & & & \\
\hline - & Firewood & coniferous & $0.12 \mathrm{~m}^{3} \mathrm{rw} / \mathrm{GJ}^{\mathrm{b}}$ & $47 \mathrm{~m}^{3} / \mathrm{GJ}$ \\
\hline - & Firewood & $\begin{array}{l}\text { non- } \\
\text { coniferous }\end{array}$ & $0.09 \mathrm{~m}^{3} \mathrm{rw} / \mathrm{GJ} \mathrm{c}^{\mathrm{c}}$ & $21 \mathrm{~m}^{3} / \mathrm{GJ}$ \\
\hline- & Pellets & - & $0.14 \mathrm{~m}^{3} \mathrm{rw} / \mathrm{GJ}$ & $41 \mathrm{~m}^{3} / \mathrm{GJ}$ \\
\hline- & $\begin{array}{l}\text { Pressed logs and } \\
\text { briquettes }\end{array}$ & - & $0.23 \mathrm{~m}^{3} \mathrm{rw} / \mathrm{GJ}$ & $67 \mathrm{~m}^{3} / \mathrm{GJ}$ \\
\hline- & $\begin{array}{l}\text { Bark and } \\
\text { chipped fuel }\end{array}$ & - & $0.10 \mathrm{~m}^{3} \mathrm{rw} / \mathrm{GJ}$ & $29 \mathrm{~m}^{3} / \mathrm{GJ}$ \\
\hline- & $\begin{array}{l}\text { Wood-based } \\
\text { ethanol }\end{array}$ & - & $0.33 \mathrm{~m}^{3} \mathrm{rw} / \mathrm{GJ}{ }^{\mathrm{d}}$ & $97 \mathrm{~m}^{3} / \mathrm{GJ}$ \\
\hline- & $\begin{array}{l}\text { Wood-based } \\
\text { ethanol }\end{array}$ & - & $7.71 \mathrm{~m}^{3} \mathrm{rw} / \mathrm{m}^{3}$ ethanol & $2260 \mathrm{~m}^{3} / \mathrm{m}^{3}$ ethanol \\
\hline 1630 & Wood charcoal & - & $0.20 \mathrm{~m}^{3} \mathrm{rw} / \mathrm{GJ}^{\mathrm{e}}$ & $59 \mathrm{~m}^{3} / \mathrm{GJ}$ \\
\hline
\end{tabular}

a For wood panels from wood particles, we assume that particles are produced from green/rough sawnwood without losses and that $1 \mathrm{~m}^{3}$ of green sawnwood has a solid wood equivalent of $1 \mathrm{~m}^{3}$ ) (UNECE/FAO, 2010).

b Higher heating value of softwood $=20.9$ GJ/t softwood (Speight, 2010); wood basic density of coniferous fuelwood logs $=0.42 \mathrm{dry}$ t/green $\mathrm{m}^{3}$ (UNECE/FAO, 2010).

${ }^{c}$ Higher heating value of hardwood = 20.0 GJ/t hardwood (Speight, 2010); wood basic density of non-coniferous fuelwood logs $=0.54$ dry $\mathrm{t} /$ green $\mathrm{m}^{3}$ (UNECE/FAO, 2010). 
Notes to Table 5-4 (continued).

d Higher heating value of ethanol = 29.7 GJ/t ethanol (Speight, 2010); ethanol density = $0.789 \mathrm{t} / \mathrm{m}^{3}$.

e Higher heating value of charcoal = 29.6 GJ/t charcoal (Speight, 2010).

\subsection{Discussion}

\subsubsection{Comparison with Previous Estimates}

A rough comparison can be made between our estimates of the water footprint of roundwood and those by Van Oel \& Hoekstra (2012) for the main pulp producing countries. Our estimates of actual evaporation rates are about $30 \%$ higher, while our wood yields are about $45 \%$ lower. We specifically estimate the evaporation of forests, while Van Oel \& Hoekstra (2012) used a general actual evaporation map (which probably underestimates forest evaporation). Where Van Oel \& Hoekstra (2012) use rough wood yield estimates per country/region, wood yields in our study are derived from national production and area statistics that were downscaled to the grid level. Moreover, we use different underlying maps of which grid cells are used for roundwood production, which contributes to different spatial average estimates of evaporation rates and water footprints. Without application of the value fraction of roundwood production, our water footprint of roundwood estimates for the main pulp producing countries are significantly higher than those by Van Oel \& Hoekstra (2012). After applying the value fractions $\left(f_{\text {value,rw }}\right)$, our estimates are roughly $20 \%$ and $140 \%$ of those by Van Oel \& Hoekstra (2012) for tropical and temperate/boreal zones, respectively. We used the same wood to paper conversion factor as Van Oel \& Hoekstra (2012), so differences in the water footprint of paper (assuming a recovery rate of zero) are also explained by the above.

When we compare the water footprint of seven wood products in China, we find that our estimates are $5 \%$ to $29 \%$ of those by Tian \& Ke (2012). We used different methods and data, but the largest difference is probably explained by the fact that we apply a value fraction.

For the southeastern United States, Chiu \& Wu (2013) found that the green water footprint of ethanol from forest wood residue is about 400-443 $1 / 1$ and that the blue water footprint in the forestry stage is minimal. Our estimated water footprint per unit of roundwood in this region is about $701 / 1$ (Figure 5-4). With a roundwood to bio-ethanol conversion factor of 6.8 for the United States (UNECE/FAO, 2010), this translates into a quite similar water footprint of $476 \mathrm{l} / \mathrm{l}$. Where we applied a value fraction to attribute 
forest evaporation to roundwood production followed by a roundwood to bio-ethanol conversion factor, Chiu \& Wu (2013) allocated forest evaporation to bio-ethanol production based on an estimated weight fraction of harvested wood residue for bioethanol in the total above-ground wood mass, which also greatly reduces the amount of evaporation attributed to the bio-ethanol.

\subsubsection{Uncertainties Regarding Method and Data}

Moisture Recycling

Precipitation over land relies on terrestrial evaporation (moisture recycling) to a varying extent around the globe (van der Ent et al., 2010) and forests play an important role in this (Ellison et al., 2012). When attributing forest evaporation to forestry products, one could argue to reduce total forest evaporation by the portion of evaporation that returns as precipitation (in the same area), based on the idea that this returning water can be used again and therefore is not really consumed (Launiainen et al., 2014). However, green forest evaporation stems from the precipitation amount that already includes the recycled moisture. Reducing the attributed evaporation by the recycled part would wrongly suggest that the recycled water is left for use for other purposes. It is not additional water that can be additionally allocated. As mentioned in the introduction, we are interested in this question of water allocation: which part of the available flow is being appropriated for roundwood production? Therefore, we deliberately attribute the total forest evaporation (that is reduced based on a value fraction) to roundwood production, whatever rate of moisture recycling.

\section{Uncertainties Regarding Data}

The estimates of the water footprint of roundwood production provided in this study are subject to a number of uncertainties. Since the fraction of water in the harvested wood turned out to be negligible (Section 5.3.1), the main variables governing the end result are the forest evaporation ( $\left.E_{\text {act }}\right)$, the area used for roundwood production $\left(A_{\mathrm{rw}}\right)$, the volume of roundwood produced $\left(P_{\text {act }}\right)$ and the value fraction of roundwood production $\left(f_{\text {value,rw }) \text {. }}\right.$

Out of these, we expect the least uncertainty in Eact and Pact. The estimate of Eact is relatively straightforward and bound by annual precipitation and potential evaporation. $P$ act is based on downscaled national statistics covering the entire study period, although the downscaling to the grid level involved coarse data on long-term maximum sustainable wood yields. The current data limitations regarding $A_{\mathrm{rw}}$ (Kuemmerle et al., 2013) makes our estimate of $A_{\mathrm{rw}}$ rather uncertain, since it is based on a modeled wood 
harvest pattern that was scaled to an estimated area used for roundwood production based on national statistics available from 1990 onwards. The estimated relative value of ecosystem services from which we derived $f_{\text {value,rw }}$ is associated with some limitations as elaborately described by Costanza et al. (1997) and Costanza et al. (2014). The estimates are based on a limited number of valuation studies that reflect the state at a certain point in time (Costanza et al., 2014). Besides, uncertainties are associated with willingness-topay estimates and aggregation of values at specific locations to larger spatial and temporal scales (Costanza et al., 2014). Furthermore, we needed to make a number of assumptions for disaggregating the value of ecosystem services in time and space as outlined in Appendix C.6.

\subsubsection{Sustainability of the Water Footprint}

This study has provided spatially-explicit estimates of the water footprint of roundwood production and various forest products. One should be cautious in evaluating differences in the water footprints of a similar product from two different regions in terms of better or worse. The relevance of the data presented rather lies in the fact that they can form a basis for further study into the alternative uses of the same water to produce more or different goods and services.

To judge the sustainability of the water footprint of roundwood production (volume/time), one would need to place the green and blue water components in the context of maximum sustainable levels of green and blue water consumption and consider the competition for the limited green and blue water resources between different demands. This assessment was out of the scope of this study, since maximum sustainable levels are currently not known for green water (Hoekstra \& Wiedmann, 2014; Schyns et al., 2015), the major component of the water footprint of roundwood production. Besides, for understanding competing demands for water and the potential conflict between (green) water use for roundwood production and (green) water use for other purposes like crops for food, feed or bioenergy, a broader study would be required. Nevertheless, we can roughly contextualize the water footprint of roundwood production based on previous work.

\section{Addition of the Forestry Sector to the Water Footprint of Humanity}

We can place the global water consumption attributed to roundwood production in the context of the global water footprint for the period 1996-2005 as estimated by Hoekstra \& Mekonnen (2012), who considered the following five sectors: crop production, pasture, water supply in animal raising, industrial production, and domestic water supply. 
Addition of the forestry sector raises the global consumptive (green plus blue) water footprint of production for the period 1996-2005 by $12 \%$.

Trade-offs Between Water for Food, Feed, Energy and Wood

The estimated water footprints of roundwood represent the volume of water that is allocated to wood production, albeit implicitly through land-use decisions (Rockström \& Gordon, 2001). Alternatively, this water could be used for the generation of other terrestrial ecosystem services or crop production (Rockström \& Gordon, 2001; Rockström et al., 1999). We made a rough comparison between the value of water for roundwood and three major food/feed crops (Table 5-5) as well as the water footprint of bio-ethanol per unit of energy from these four sources (Table 5-6). Both regarding economic water productivity and the water footprint of bio-ethanol, roundwood is comparable with maize, ranking somewhat better compared to wheat and worse compared to sugar beet. It should be noted that the water footprint of second-generation bio-ethanol obtained from crop residues is smaller than the water footprint of first-generation bio-ethanol from these crops (Mathioudakis et al., 2017).

Mekonnen et al. (2015) compared the water footprint of heat from various energy sources, including that from firewood based on Van Oel \& Hoekstra (2012). Although our estimates of the water footprint of heat from wood (i.e. firewood, pellets, briquettes, bark, chips, charcoal) are different (Section 5.4.1), they remain orders of magnitude larger than the water footprint from other energy sources such as coal, lignite, oil, gas and nuclear (Mekonnen et al., 2015). From this perspective, burning wood for the generation of heat and electricity still is not recommended (Mekonnen et al., 2015). 
Table 5-5. Economic water productivity (EWP) of roundwood (rw) compared to three major food/feed crops. EWP is calculated as the price divided by the green plus blue water footprint (WF). Global average WF of crops obtained from Mekonnen \& Hoekstra (2011a) and ranges from Mekonnen \& Hoekstra (2014).

\begin{tabular}{|c|c|c|c|c|c|c|c|}
\hline $\begin{array}{l}\text { Alter- } \\
\text { native } \\
\text { uses }\end{array}$ & Price $^{a}$ & $\begin{array}{l}W F_{\min ^{\mathrm{b}}} \\
\left(\mathrm{m}^{3} / \mathrm{unit}\right. \\
\text { of } \\
\text { product) }\end{array}$ & $\begin{array}{l}W F_{\text {avg }} \\
\left(\mathrm{m}^{3} / \text { unit }\right. \\
\text { of } \\
\text { product) }\end{array}$ & $\begin{array}{l}W F_{\max }{ }^{\mathrm{c}} \\
\left(\mathrm{m}^{3} / \mathrm{unit}\right. \\
\text { of } \\
\text { product) }\end{array}$ & $\begin{array}{l}E W P_{\max } \\
(\mathrm{US} \$ / \\
\left.\mathrm{m}^{3}\right)\end{array}$ & $\begin{array}{l}\text { EWPavg } \\
(\mathrm{US} / \\
\left.\mathrm{m}^{3}\right)\end{array}$ & $\begin{array}{l}E W P_{\min } \\
(\mathrm{US} \$ / \\
\left.\mathrm{m}^{3}\right)\end{array}$ \\
\hline $\begin{array}{l}\text { Round } \\
\text { wood }\end{array}$ & $\begin{array}{r}94 \$ / \mathrm{m}^{3} \\
\mathrm{rw}\end{array}$ & $\begin{array}{r}68 \mathrm{~m}^{3} / \mathrm{m}^{3} \\
\mathrm{rw}\end{array}$ & $\begin{array}{r}293 \\
\mathrm{~m}^{3} / \mathrm{m}^{3} \\
\mathrm{rw}\end{array}$ & $\begin{array}{r}584 \\
\mathrm{~m}^{3} / \mathrm{m}^{3} \\
\mathrm{rw}\end{array}$ & 1.4 & 0.3 & 0.2 \\
\hline Wheat & $289 \$ / t$ & $992 \mathrm{~m}^{3} / \mathrm{t}$ & $\begin{array}{l}1620 \\
\mathrm{~m}^{3} / \mathrm{t}\end{array}$ & $\begin{array}{r}2091 \\
\mathrm{~m}^{3} / \mathrm{t}\end{array}$ & 0.3 & 0.2 & 0.1 \\
\hline Maize & $349 \$ / t$ & $542 \mathrm{~m}^{3} / \mathrm{t}$ & $\begin{array}{l}1028 \\
\mathrm{~m}^{3} / \mathrm{t}\end{array}$ & $\begin{array}{l}1385 \\
\mathrm{~m}^{3} / \mathrm{t}\end{array}$ & 0.6 & 0.3 & 0.3 \\
\hline $\begin{array}{l}\text { Sugar } \\
\text { beet }\end{array}$ & $81 \$ / t$ & $58 \mathrm{~m}^{3} / \mathrm{t}$ & $108 \mathrm{~m}^{3} / \mathrm{t}$ & $151 \mathrm{~m}^{3} / \mathrm{t}$ & 1.4 & 0.8 & 0.5 \\
\hline
\end{tabular}

a Price for roundwood is the average export unit price in UNECE countries for the period 2005-2014 obtained from UNECE/FAO (2015). Prices for crops are average producer prices for the period 2005-2014 obtained from FAO (2016d).

${ }^{\mathrm{b}} W F$ at $20^{\text {th }}$ percentile of production.

${ }^{c} W F$ at $80^{\text {th }}$ percentile of production. 
Table 5-6. Water footprint (WF) of bio-ethanol from roundwood (rw) compared to the WF of first-generation bio-ethanol from three crops. Global average WF of crops obtained from Mekonnen \& Hoekstra (2011a) and ranges from Mekonnen \& Hoekstra (2014). Water footprints refer to the water use in the biomass production stage (crop and wood growth).

\begin{tabular}{|c|c|c|c|c|c|c|c|}
\hline $\begin{array}{l}\text { Bio- } \\
\text { ethanol } \\
\text { from }\end{array}$ & $\begin{array}{l}\text { Energy } \\
\text { yield }^{\mathrm{a}}\end{array}$ & $\begin{array}{l}W F_{\min ^{b}} \\
\left(\mathrm{~m}^{3} / \mathrm{unit}\right. \\
\text { of } \\
\text { product) }\end{array}$ & $\begin{array}{l}W F_{\text {avg }} \\
\left(\mathrm{m}^{3} / \text { unit }\right. \\
\text { of } \\
\text { product) }\end{array}$ & $\begin{array}{l}W F_{\max ^{c}} \\
\left(\mathrm{~m}^{3} / \mathrm{unit}\right. \\
\text { of } \\
\text { product) }\end{array}$ & $\begin{array}{l}W F_{\min } \\
\left(\mathrm{m}^{3} /\right. \\
\mathrm{GJ})\end{array}$ & $\begin{array}{l}W F_{\text {avg }} \\
\left(\mathrm{m}^{3 /}\right. \\
\mathrm{GJ})\end{array}$ & $\begin{array}{l}W F_{\text {max }} \\
\left(\mathrm{m}^{3 /}\right. \\
\mathrm{GJ})\end{array}$ \\
\hline $\begin{array}{l}\text { Round } \\
\text { wood }\end{array}$ & $\begin{array}{r}3.0 \mathrm{GJ} / \mathrm{m}^{3} \\
\mathrm{rW}\end{array}$ & $\begin{array}{r}68 \mathrm{~m}^{3} / \mathrm{m}^{3} \\
\mathrm{rw}\end{array}$ & $\begin{array}{r}293 \mathrm{~m}^{3} / \mathrm{m}^{3} \\
\mathrm{rw}\end{array}$ & $\begin{array}{r}584 \mathrm{~m}^{3} / \mathrm{m}^{3} \\
\mathrm{rw}\end{array}$ & 23 & 98 & 195 \\
\hline Wheat & $10.2 \mathrm{GJ} / \mathrm{t}$ & $992 \mathrm{~m}^{3} / \mathrm{t}$ & $1620 \mathrm{~m}^{3} / \mathrm{t}$ & $2091 \mathrm{~m}^{3} / \mathrm{t}$ & 98 & 159 & 206 \\
\hline Maize & $10.0 \mathrm{GJ} / \mathrm{t}$ & $542 \mathrm{~m}^{3} / \mathrm{t}$ & $1028 \mathrm{~m}^{3} / \mathrm{t}$ & $1385 \mathrm{~m}^{3} / \mathrm{t}$ & 54 & 103 & 139 \\
\hline $\begin{array}{l}\text { Sugar } \\
\text { beet }\end{array}$ & $2.6 \mathrm{GJ} / \mathrm{t}$ & $58 \mathrm{~m}^{3} / \mathrm{t}$ & $108 \mathrm{~m}^{3} / \mathrm{t}$ & $151 \mathrm{~m}^{3} / \mathrm{t}$ & 22 & 41 & 58 \\
\hline
\end{tabular}

a Energy yield of roundwood is the inverse of the conversion factor for wood-based ethanol in Table 4. Energy yield of crops obtained from Mekonnen \& Hoekstra (2011a).

${ }^{\mathrm{b}} W F$ at $20^{\text {th }}$ percentile of production.

${ }^{c} W F$ at $80^{\text {th }}$ percentile of production. 


\subsubsection{Reduction of the Water Footprint}

Intensification vs. Extensification of Wood Production

Intensification of wood production has two counteracting effects on the water footprint per unit of roundwood produced ( $W F_{\mathrm{rw}}$, Eq. 5-7). Effect $\mathrm{A}$ is that the value of wood production increases, partially at the expense of other ecosystem service values ( $f_{\text {value,rw }}$ increases), such that the water consumption attributed to roundwood production increases. Effect B is that more wood is produced per ha with the same amount of water. Intensification of wood production can only reduce $W F_{\text {rw }}$ if the additional wood value per ha (effect B) outweighs the loss of value of other ecosystem services (effect A).

The relationship between $f_{\text {value,rw }}$ and the intensity of forest exploitation (see Appendix C.6) determines whether effect $A$ is stronger than effect $B$ or vice versa and hence whether $W F_{\text {rw }}$ increases (when effect $A>$ effect $B$ ) or decreases (when effect $A<$ effect $B$ ) with intensified production. This relationship is different in (sub)tropical forests compared to temperate/boreal forests, and furthermore depends on the long-term maximum sustainable yield ( $\left.Y_{\text {sus }}\right)$ : the higher $Y_{\text {sus }}$ the larger the theoretical potential to obtain a high value of wood production from the forest.

For (sub)tropical forests we found that intensification leads to an increase in $W F_{\mathrm{rw}}$ for $Y_{\text {sus }}<25 \mathrm{~m}^{3} /$ ha (which is always the case in our study; see Table 5-1). For temperate/boreal forests we found that intensification results in an increase in $W F_{\text {rw }}$ for $Y_{\text {sus }}<4.5 \mathrm{~m}^{3} /$ ha, but a decrease in $W F_{\mathrm{rw}}$ for higher $Y_{\text {sus. Although we recognize that }}$ further research is needed into the value of forests and their maximum sustainable yields - with more spatiotemporal detail than was available for this study - the following

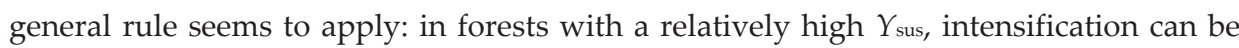
beneficial in terms of water use efficiency, since the positive effect of intensification (effect B) can outweigh the loss of value of other ecosystem services (effect A).

\section{Recycling}

The water footprint of roundwood can effectively be reduced through recycling. The use of recycled wood nullifies the attributed evaporation to roundwood production, since no new wood is produced. In this study, recovery rates were not considered. Hence, water footprint estimates refer to newly produced products. Van Oel \& Hoekstra (2012) already concluded that increasing paper recovery rates is a powerful way to reduce the water footprint of paper. Other wood products can also be recycled in various ways. Wooden pallets or furniture can be reused or be remanufactured from recovered wood, just like particle board (Falk \& McKeever, 2004). In construction, wood recovered during 
demolition is potentially suitable for reuse or remanufacture, particularly into flooring (Falk \& McKeever, 2004). Chipped or shredded wood can be used as basis for fuel, landscaping mulch, composting bulk agent, sewage sludge bulking medium, or animal bedding (Falk \& McKeever, 2004). Ideally, the cascading use principle is applied, in which wood is used, recycled and reused as long as possible before ultimately being used as an energy source (Dammer et al., 2016). It is obvious that reduced consumption of end products from wood will eventually reduce the total water consumption related to roundwood production.

\subsection{Conclusion}

The global water consumption attributed to roundwood production for lumber, pulp, paper, fuel and firewood has risen from $768 \times 10^{9} \mathrm{~m}^{3} / \mathrm{y}$ in $1961-1970$ to $961 \times 10^{9} \mathrm{~m}^{3} / \mathrm{y}$ in 2001-2010. Recycling of wood products could effectively reduce this volume, thereby leaving more water available for the generation of other ecosystem services. Intensification of wood production can only reduce the water footprint per unit of wood if the additional wood value per ha outweighs the loss of value of other ecosystem services, which is often not the case in (sub)tropical forests. Alternatively using the water for crop production is generally not beneficial (even apart from the negative effects of converting forest to cropland), since roundwood is rather comparable with major food, feed and energy crops in terms of economic water productivity and energy yield from bio-ethanol per unit of water. The results of this study contribute to a more complete picture of the human appropriation of water and feed into the debate on water for food, feed, energy and wood. 


\title{
6. Limits to the World's Green Water Resources for Food, Feed, Fibre, Timber and Bio-Energy
}

\begin{abstract}
Freshwater stems from precipitation, which is limited in time and space. Precipitation over land partitions into a blue water flow (runoff via groundwater and surface water) and a green water flow (evaporation). Both flows are partially allocated to serve the economy; explicitly through blue water withdrawals and implicitly through the use of land with its associated green water flow. Part of the flows are not sustainably available for productive purposes, since rivers require environmental flows and at least $17 \%$ of the land needs to be protected to conserve terrestrial biodiversity according to Aichi Biodiversity Target (ABT) 11. Blue water scarcity - the degree to which blue water consumption approaches maximum sustainable levels - has been recognized as a global risk and thoroughly studied. A similar assessment for green water does not exist yet, which is remarkable given that three-fifths of precipitation over land becomes green water - the predominant source of water for agriculture and forestry. Here, we show how the world's limited green water resources are allocated to different purposes and where we approach or overshoot maximum sustainable levels. We find that green water is scarcer than blue water in 91 out of 163 countries, and that humanity is closer to the planetary boundary for green water (56\% appropriation) than for blue water $(27-54 \%$ appropriation). Human's green water footprint - the green water resources allocated to productive purposes - is close to or beyond the maximum sustainable level in Europe, Central America, the Middle East and South Asia. Globally, 18\% of the green water footprint is in areas to be reserved for nature. In quantifying the limits to green water availability, the main source of water to produce food, feed, fibre, timber and bio-energy, we emphasize the critical role green water has to play in the discourse on freshwater scarcity.
\end{abstract}

\subsection{Introduction}

Precipitation, the undifferentiated source of freshwater, partitions into blue and green water flows (Falkenmark, 2000) (Figure 6-1). Whereas the further partitioning of the blue water flow into utilizable, non-utilizable, environmental and utilized flows is known, this is not the case for the much larger green water flow. The implicit allocation of green water through land-use decisions, the lack of a price and its invisibility in the landscape make that green water - in contrast to blue water - is off the radar for economists and persists to be a blind spot for policy makers. 


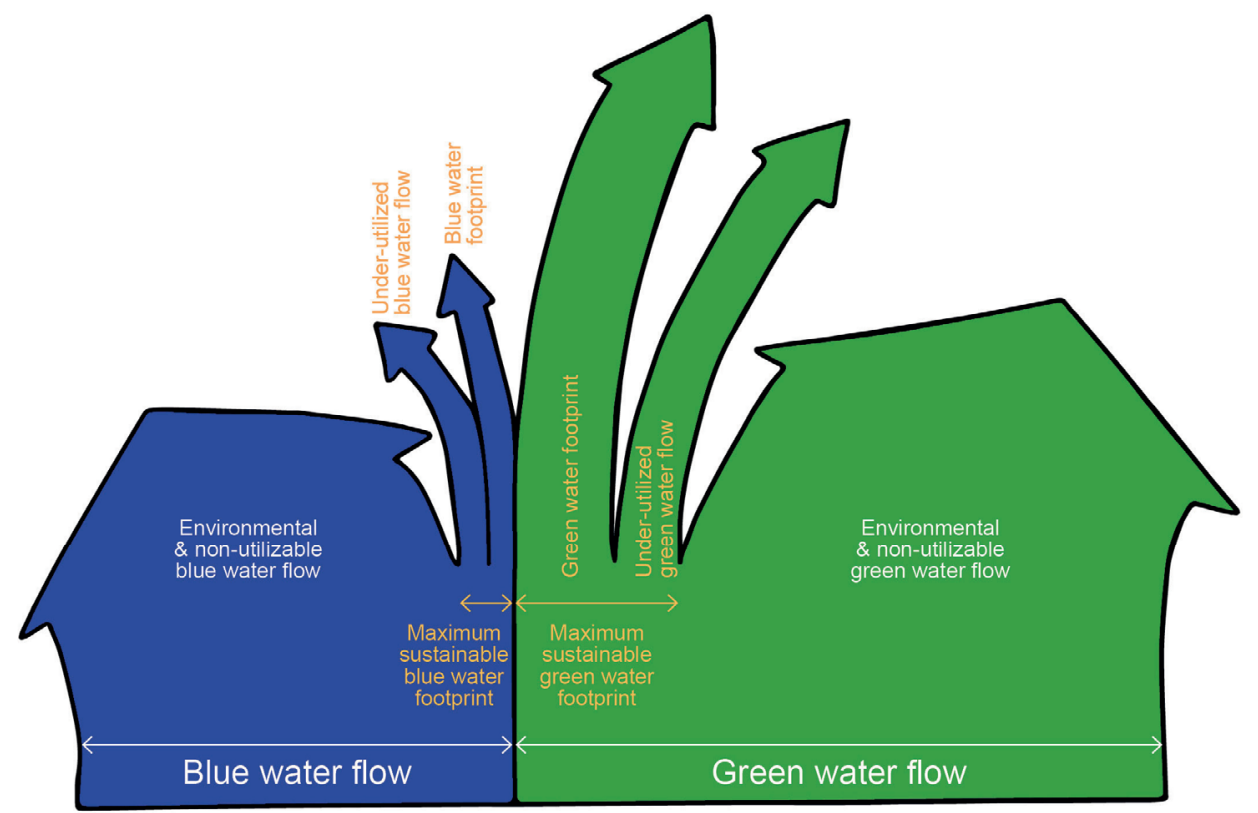

Figure 6-1. The partitioning of precipitation over land into blue and green water flows. Both flows further partition into environmental and non-utilizable (or non-accessible) flows, flows allocated to human activities (i.e. water footprint) and under-utilized flows below the maximum sustainable level. This further partitioning is known for the blue water flow (Mekonnen \& Hoekstra, 2016; Gerten et al., 2013), but unknown for the green water flow. The ratio of the actual to the maximum sustainable water footprint shows the extent to which limited water resources have been allocated to human activities and is thus an indicator of the degree of water scarcity.

Only starting from the 1990s, scholars realized the importance of green water flows to agriculture, forestry and urban areas (Postel et al., 1996; Rockström et al., 1999). Since water allocated to one purpose will no longer be available in the same area and time period for another purpose, there is a limitation to our green water footprint $\left(W F_{\mathrm{g}}\right)$, which measures the level of consumption of green water resources (Hoekstra, 2017). As the world population grows and consumes more animal products, the demand for food, feed, fibre, timber and bio-energy increases, and so does the $W F_{g}$ of humanity. Because the amount of land and associated rainwater is limited, there is a maximum sustainable level to $W F_{g}$. Moreover, biodiversity conservation (Pouzols et al., 2014) and other ecosystem services put a claim on land and the associated rainwater too, thereby constraining the expansion and intensification of land use (Kehoe et al., 2017). To date, the maximum sustainable green water footprint $\left(W F_{g, m}\right)$ has not been quantified. Although the need for a planetary boundary on green water $\left(P B_{\mathrm{g}}\right)$ has been recognized 
(Gerten et al., 2013), previous research efforts only considered the planetary boundary on blue water (Steffen et al., 2015).

Recently, indicators for combined green-blue water scarcity have been developed (Rockström et al., 2009; Gerten et al., 2011; Kummu et al., 2014), comparing a hypothetical water demand for food self-sufficiency to the natural water endowment of a region, which can provide useful information on potential food self-sufficiency in a region (Schyns et al., 2015). However, these indicators are not suitable for measuring the degree to which limited green water resources have been actually allocated to human activities (Schyns et al., 2015). First, they do not account for green water consumption associated with the actual production pattern, which includes green water use related to production for export. Second, because of their focus on food, they exclude the WFg of wood production (Schyns et al., 2017). Third, green water availability in these water scarcity indicators is taken as the green water flow from existing agricultural land, which excludes green water flows on currently non-utilized yet potentially utilizable lands. Fourth, with these indicators a high degree of green water scarcity can be masked by a low degree of blue water scarcity, which makes them unsuitable to identify areas where competition is essentially about green water (Schyns et al., 2015).

We aim to illustrate the critical role green water plays in the discourse on freshwater scarcity, by quantifying the allocation of the world's green water resources and comparing green WFs to regional maximum sustainable levels of green water availability.

\subsection{Method and Data}

We estimate $W F_{g}$ of crop production, livestock grazing, wood production and urban areas at a $5 \times 5$ arc minute grid cell spatial resolution, using a sophisticated allocation procedure that includes accounting for ecosystem services provided by forests and pastures. For each grid cell, we calculate green water under-utilization $\left(W F_{g}<W F_{g, m}\right)$ or over-utilization $\left(W F_{g}>W F_{g, m}\right)$. Next, we express the degree of green water scarcity $\left(W S_{g}\right)$ per country as the ratio of the country sum of $W F_{g}$ to the country sum of $W F_{g, m}$ (Figure 61). Last, we estimate the global fraction of green water resources appropriation as the ratio of the global aggregate $W F_{g}$ to the global aggregate $W F_{g, m}$, whereby the latter can be interpreted as the planetary boundary for green water $\left(P B_{\mathrm{g}}\right)$. 


\subsubsection{Actual Green Water Footprints of Crop and Wood Production}

$W F_{g}$ of crop production is estimated for 126 crops with a grid-based soil water balance model at 5 × 5 arc minute spatial resolution for the period 1996-2005 taken from Mekonnen \& Hoekstra (2011a). We averaged WFg of wood production for 2000-2009 at $30 \times 30$ arc minute from Schyns et al. (2017) and downscaled this to $5 \times 5$ arc minute based on an equal share for all grid cells that are not strictly protected.

\subsubsection{Actual Green Water Footprint of Urban Areas}

$W F_{g}$ of urban areas is estimated at $5 \times 5$ arc minute resolution by multiplying urban areas with an estimate of the average annual evaporation rate from urban areas for 2000-2009. We first estimated urban areas at $0.05 \times 0.05$ degree resolution by multiplying fractional urban cover with the grid cell area, after which we aggregated absolute areas to $5 \times 5$ arc minute resolution. The map (Friedl \& Sulla-Menashe, 2015) of fractional urban cover for the year 2012 is based on Friedl et al. (2010) and Schneider et al. (2010). The annual evaporation rate from urban area $E_{\mathrm{g}}(\mathrm{m} / \mathrm{y})$ in grid cell $x$ is estimated using the formula by Zhang et al. (2001) based on the average annual precipitation $P(\mathrm{~m} / \mathrm{y})$ and potential evaporation $E_{0}(\mathrm{~m} / \mathrm{y})$ for the period 2000-2009 - both estimated from daily climate data at 30 × 30 arc minute resolution (De Graaf et al., 2014) - and a dimensionless coefficient representing plant water availability $w$. Based on an average for 386 European cities (Fuller \& Gaston, 2009), we assumed urban area is made up of $20 \%$ green space and $80 \%$ built-up cover. For green space (grass-like cover), we applied a $w$ of 0.5 and for built-up cover a $w$ of 0.1 , which represents very low ability to store water in or on the surface readily available for evaporation (Zhang et al., 2001).

\subsubsection{Actual Green Water Footprint of Livestock Grazing}

We estimated $W F_{g}$ of grazing per year at $5 \times 5$ arc minute resolution and then averaged it for 2000-2009. First, for the locations where livestock is present (see next paragraph) we estimated the area used for grazing as the area of permanent meadows and pastures minus the area of harvested fodder grasses (which are included in $W F_{g}$ of crop production). Second, we estimated the total green water flow over the area used for grazing by multiplication with an actual evaporation rate of grazed grassland. Third, we attributed a fraction of this total green water flow to grazing, based on the ratio of the economic value of meat and milk production from grazed lands to the total value of grazing lands (which also includes the values of other ecosystem services that these lands provide, see below). Materials are described in the Table D-1 (Appendix D.1). Our $W F_{g}$ of grazing estimate is discussed in the context of previous assessments in Appendix D.3. 


\subsubsection{Spatiotemporal Distribution of Animal Heads per Production System}

First, we estimated the number of grazing animals at $5 \times 5$ arc minute resolution for each year in 2000-2009. Second, we determined per grid cell per year the spread of these animals over these two production systems: pastoral and mixed/landless. We considered the following grazing animal categories: dairy cattle, non-dairy cattle, asses, buffaloes, camels, horses, mules, llamas, sheep and goats. We disaggregated national annual statistics on stocks of these animal categories (FAO, 2016c) to a $5 \times 5$ arc minute grid, using weights derived from livestock distribution data (Robinson et al., 2014; Wint \& Robinson, 2007). To obtain the weight per $5 \times 5$ arc minute grid cell, we first converted livestock densities (Robinson et al., 2014; Wint \& Robinson, 2007) - available at a finer resolution - to absolute heads by multiplying density with the grid cell area, and aggregated those numbers to $5 \times 5$ arc minute resolution. Second, we calculated from this map the weight per grid cell as the ratio of animal heads in the grid cell to the total animals heads present in the country. The spread of the animals over the two production systems per grid cell is based on Robinson et al. (2011) and the change in production over these two systems during our study period is estimated based on a an annual rate of change derived from Bouwman et al. (2005) (Table D-1, Appendix D.1).

\subsubsection{Attribution of the Green Water Flow to the Productive Use Based on a Value Fraction}

While the generation of other ecosystem services on cropland is often assumed negligible in water accounting exercises (all evaporation during the growing season is accounted to crop production) (Rost et al., 2008; Liu et al., 2009; Mekonnen \& Hoekstra, 2011a; Hoekstra \& Mekonnen, 2012), land that is utilized for livestock grazing or wood production may also generate a significant amount of other ecosystem service values (Costanza et al., 1997; Costanza et al., 2014). For these lands, we therefore only attributed a part of the year-round green water flow to the productive uses. Following Schyns et al. (2017), this attribution is based on a value fraction that is defined as the ratio of the monetary value of the productive use to the total monetary value of the ecosystem services generated on a unit of land. As the land utilization rate $(\beta)$ approaches the maximum sustainable land utilization rate $(\beta \mathrm{m})$, the value of the productive use increases, but the value of some of the ecosystem services get reduced, while some other ecosystem services maintain their value irrespective of $\beta$ (see Figure D-7, Appendix D.2).

For livestock grazing, we estimated the value fraction of meat and milk production from grazing pastures per country for each year in the period 2000-2009. We use global ecosystem service values of grasslands for 2011 (Costanza et al., 2014), which we 
distributed over grazed and non-grazed grasslands. We then estimate per country per year the value of meat and milk production and the value of ecosystem services that are inversely proportional to the intensity of grazing (see below) as described in Table D-2 (Appendix D.1).

\subsubsection{Estimation of the Intensity of Grazing}

The intensity of grazing $(\alpha)$ in a country is estimated per year as the ratio of the total grass consumed through grazing by animals to the maximum sustainable grass production on grazed pastures. The total grass consumed through grazing by animals is estimated backwards from national annual statistics on meat and milk production in two steps. First, we converted meat and milk production per animal category per production system to the associated total grass consumed (including fodder grasses that are not directly grazed, but harvested and fed to livestock later) using feed conversion efficiencies and the fraction of grass in feed (Table D-1, Appendix D.1). Second, we estimated the grass consumed by all animals in a production system and subtracted the production of fodder grasses from the total grass consumed in the intensive system (assuming that fodder grasses are fed to livestock in this system within the country in that year). The maximum sustainable grass production on grazed pastures is estimated by multiplying the area used for grazing with the maximum sustainable grass yield. In cases where $\alpha$ exceeds one - i.e. grazed grass consumption is larger than the sustainable grass production on grazed pastures - we assumed fully intensive use of the grazed pastures, but limited the grass consumed through grazing to the sustainable grass production on grazed pastures. This happens in small and arid countries with a substantial livestock sector that in practice relies on imported animal feed.

\subsubsection{Land Set Aside for Nature: Protected Areas and Global Priority Areas for Protection}

Protected area polygons (IUCN \& UNEP-WCMC, 2016) were converted to a discrete raster of $5 \times 5$ arc minute grid cells, whereby a grid cell is considered fully protected if $>50 \%$ is covered by a protected area polygon. Following Schyns et al. (2017) and Smith et al. (2012), we only considered strictly protected areas, including strict nature reserves (IUCN category Ia), wilderness areas (IUCN category $\mathrm{Ib}$ ) and national parks (IUCN category II). Priority areas for protection, representing the most suitable $17 \%$ of the terrestrial land for protection based on conservation value, were obtained from Pouzols et al. (2014) using the map for present land-use conditions. We resampled the original discrete $0.2 \times 0.2$ degree raster to $5 \times 5$ arc minute. 


\subsubsection{Maximum Sustainable Green Water Footprints on Non-Utilized Utilizable Land}

To estimate $W F_{g, m}$ for utilizable lands that are currently non-utilized, we first needed to identify where these lands are located. For this, we used - besides the land set aside for nature - three maps at $5 \times 5$ arc minute resolution: global land cover for 2012 (Friedl et al., 2010), existing cropland around 2000 (Ramankutty et al., 2008) and non-accessible or non-productive land (Erb et al., 2007). We also used a map of agricultural suitability that considers rain-fed conditions (and irrigation on currently irrigated areas) and several constraints on climate, soil and slope (Zabel et al., 2014). This map represents the maximum suitability index (ranging from 0 to 100) of 16 crops at $30 \times 30$ arc second resolution, which we resampled to $5 \times 5$ arc minute using the average suitability index. We applied several constraints to determine non-utilized yet utilizable land for crop production or livestock grazing. Land is considered non-utilized yet utilizable if:

- land cover is open shrublands, savannas, grasslands, croplands, cropland/natural vegetation, barren/sparsely vegetated (similar to previous studies we do not consider agricultural expansion into forests (Lambin \& Meyfroidt, 2011; Smith et al., 2012; Eitelberg et al., 2015));

- agro-ecologically suitable (suitability index $>0$ );

- not classified as non-accessible or non-productive;

- not set aside for nature;

- $\quad$ not currently utilized (utilized area is subtracted from grid cell total area);

- resulting area is reduced by $15 \%$ to account for previously unaccounted land uses that reduce the potentially available land for agriculture (Eitelberg et al., 2015);

- grid cells with a suitability index $\geq 40$ are considered suitable for crop production, the rest is considered suitable for grazing.

Land is considered non-utilized yet utilizable for wood production if:

- land cover is evergreen needleleaf forest, evergreen broadleaf forest, deciduous needleleaf forest, deciduous broadleaf forest, mixed forest, closed shrublands or woody savannas;

- not classified as non-accessible or non-productive;

- not set aside for nature;

- average actual annual forest evaporation $\geq 100 \mathrm{~mm} / \mathrm{y}$ (Schyns et al., 2017);

- not currently utilized (utilized area is subtracted from grid cell total area); 
- resulting area is reduced by $15 \%$ to account for previously unaccounted land uses that reduce the potentially available land for wood production (Eitelberg et al., 2015).

Non-utilized utilizable land for crop production has a $W F_{g, m}$ equal to the fraction $\gamma$ of the year-round green water flow that is representative for the green water flow during the (potential) crop growing period. The year-round green water flow is estimated based on the method proposed by Zhang et al. (2001), with E0 as Penman-Monteith FAO reference potential evaporation (assuming a crop factor of 1.0) and $w$ at 0.5. Hanasaki et al. (2010) estimated $\gamma$ at roughly 0.6 (major crops). Liu \& Yang (2010) found that about $80 \%$ of evaporation from cropland (incl. blue water) took place within the crop growing period (major crops). This value is rather high, since it includes blue water that is applied during the crop growing season. We carried out a global simulation of wheat for the period 1961-2010 (unpublished work) with the AquaCrop model (Steduto et al., 2009), thereby separating green and blue evaporation (Chukalla et al., 2015). From this simulation, we found that $\gamma$ varies from 0.6 in the tropics to 0.7 or 0.8 in the temperate and boreal zones. We decided to use a spatially-uniform $\gamma$ of 0.7 .

Non-utilized utilizable land for livestock grazing and wood production has a $W F_{g, m}$ equal to the attributed fraction of the year-round green water flow at the maximum sustainable land utilization rate. For livestock grazing, the year-round green water flow is taken from Rolinski et al. (2017) (Table D-1, Appendix D.1) and the value fraction is estimated assuming that animals are kept in a pastoral system (which determines the value of food production via the fraction of grass in the animal diet and the feed conversion efficiency). For wood production, the year-round green water flow is estimated based on the method proposed by Zhang et al. (2001), in which $E_{0}$ is estimated based on mean annual temperature $T\left({ }^{\circ} \mathrm{C}\right)$ (De Graaf et al., 2014) using the empirical equation derived in Komatsu et al. (2012), and $w$ is 2.0 (Schyns et al., 2017). Last, we assumed there is no contribution from capillary rise (blue water).

\subsubsection{Green Water Flow from Land Set Aside for Nature and Non-Utilizable Land}

The non-utilizable land is estimated by subtracting utilizable area from the total area at the grid cell level. The year-round green water flow from land set aside for nature and non-utilizable land is estimated based on the method proposed by Zhang et al. (2001). The values for $E_{0}$ and $w$ depend on the land cover in a $5 \times 5$ arc minute grid cell (Friedl et al., 2010). For wood cover (IGBP classes 1-6, 8), we used a $w$ of 2.0 and estimated $E_{0}$ as described above. For grass-like cover (IGBP classes 7,9,10,12,14,16), E0 is estimated using 
Penman-Monteith FAO reference evaporation, and $w$ is set at 0.5. We assumed there is no green water flow from the land cover types permanent wetlands (class IGBP class 11) and snow and ice (IGBP class 15).

\subsubsection{Blue Water Scarcity per Country}

Blue water scarcity $\left(W S_{b}\right)$ per country is calculated by first dividing the blue water footprint of national production $\left(W F_{b}\right)$ by the maximum sustainable blue water footprint $\left(W F_{\mathrm{b}, \mathrm{m}}\right)$ on a monthly scale, and subsequently taking the average of these monthly ratios. Monthly $W F_{b}$ has been obtained from Mekonnen \& Hoekstra (2011b). WF $F_{b, m}$ has been calculated by subtracting the environmental flow requirement (EFR) from the total renewable water resources (TRWR) of a country. Estimates on annual TRWR per country were taken from (FAO, 2012a) and we subsequently converted these annual estimates into monthly values using hydrographs from the Composite Runoff V1.0 database (Fekete et al., 2002). Following Hoekstra et al. (2012), we allocated $80 \%$ of natural runoff as EFR in accordance with the precautionary rule proposed in Richter et al. (2012).

\subsection{Results}

We found that with a global $W F_{g}$ of $9.9 \times 10^{3} \mathrm{~km}^{3} / \mathrm{y}$, humanity appropriates $56 \%$ of the planetary boundary for green water $\left(18 \times 10^{3} \mathrm{~km}^{3} / \mathrm{y}\right)$. The total global $W F_{g}$ (Figure D-1, Appendix D.2) is made up of $5.7 \times 10^{3} \mathrm{~km}^{3} / \mathrm{y}$ for crop production (58\%), 2.9x $10^{3} \mathrm{~km}^{3} / \mathrm{y}$ for livestock grazing (29\%), $0.9 \times 10^{3} \mathrm{~km}^{3} / \mathrm{y}$ for wood production (9\%) and $0.3 \times 10^{3} \mathrm{~km}^{3} / \mathrm{y}$ for urban areas (3\%) (Figure 6-2). On the contrary, the blue water footprint of humanity estimated at $1.0 \times 10^{3} \mathrm{~km}^{3} / \mathrm{y}$ (Hoekstra \& Mekonnen, 2012) to $1.5 \times 10^{3} \mathrm{~km}^{3} / \mathrm{y}$ (Wada et al., 2014 ) - is only $27 \%$ respectively $38 \%$ of the most-cited planetary boundary for blue water (Steffen et al., 2015), or 37\% respectively 54\% if a stricter boundary is used (Gerten et al., 2013). Humanity is therefore closer to the planetary boundary for green than for blue water. 


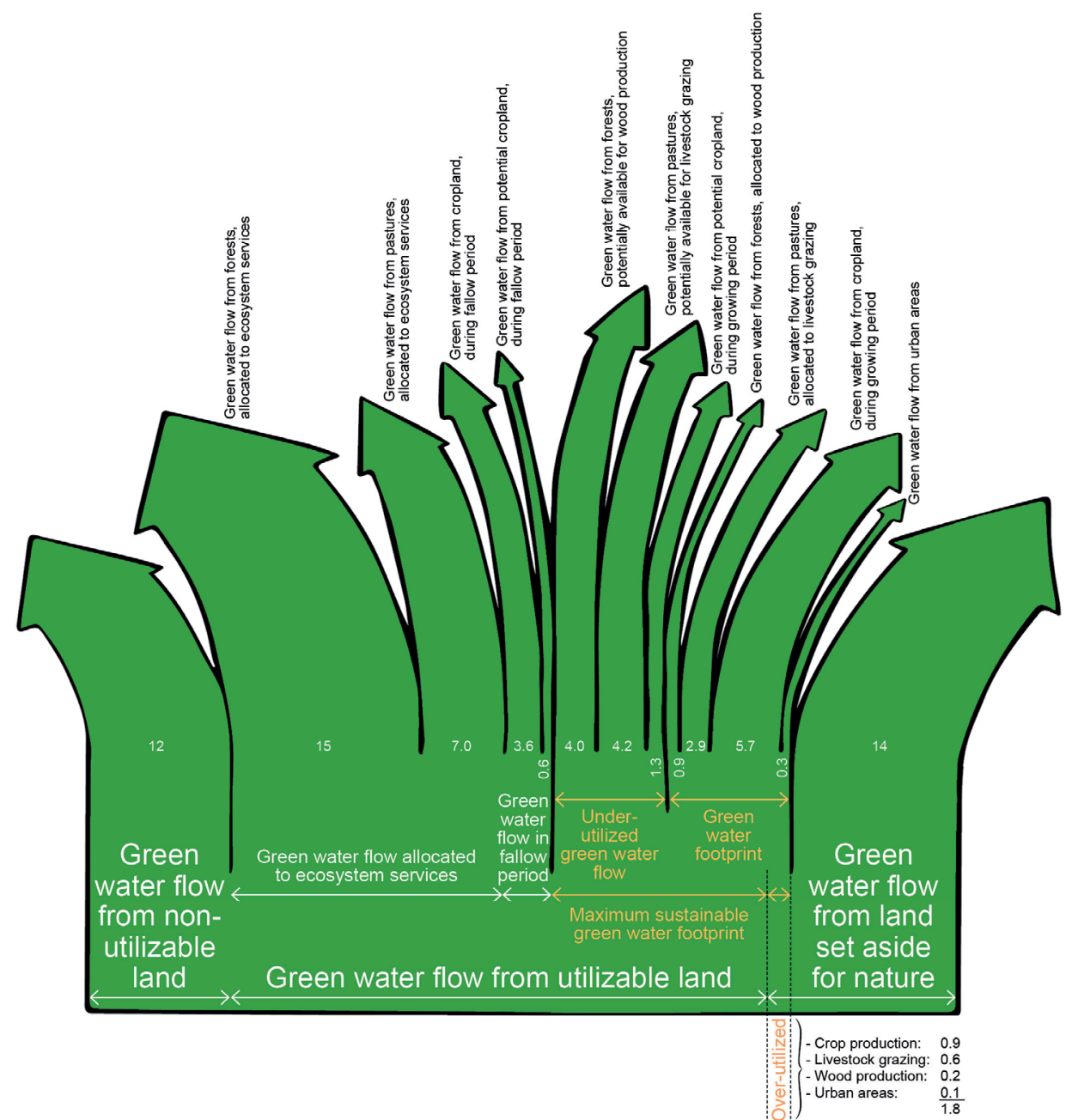

Figure 6-2. Allocation of the total green water flow from the terrestrial Earth surface $\left(72 \times 10^{3} \mathrm{~km}^{3} / \mathrm{y}\right)$. Values are in thousand $\mathrm{km}^{3} / \mathrm{y}$.

The total appropriation of green water is approaching or exceeding the maximum sustainable level in Europe, Central America, the Middle East and South Asia (Figure 63). Striking examples of countries with a high degree of $W S_{g}$ are the United Kingdom (1.3), Germany (1.8) and the Netherlands (2.5), since these countries have ample rainfall and consequently a large green water flow. However, they also fully utilize that flow and even tap into green water flows in lands designated as priority areas for protection. 


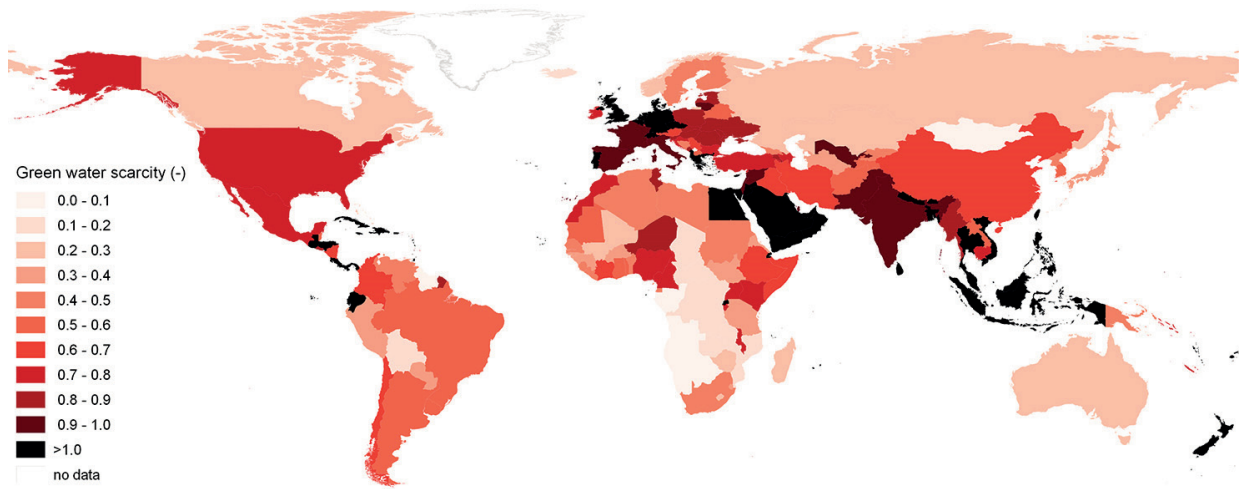

Figure 6-3. Green water scarcity $\left(W S_{g}\right)$ per country, expressed as the ratio of the national aggregate $W F_{g}$ to the national aggregate $W F_{g, m}$. Countries with $W S_{g}=1$ are fully utilizing their available green water flow or under- and over-utilization cancel each other out at the country scale. $W F_{g}, W F_{g, m}$ and $W S_{g}$ per country are included in Table D-3 (Appendix D.1).

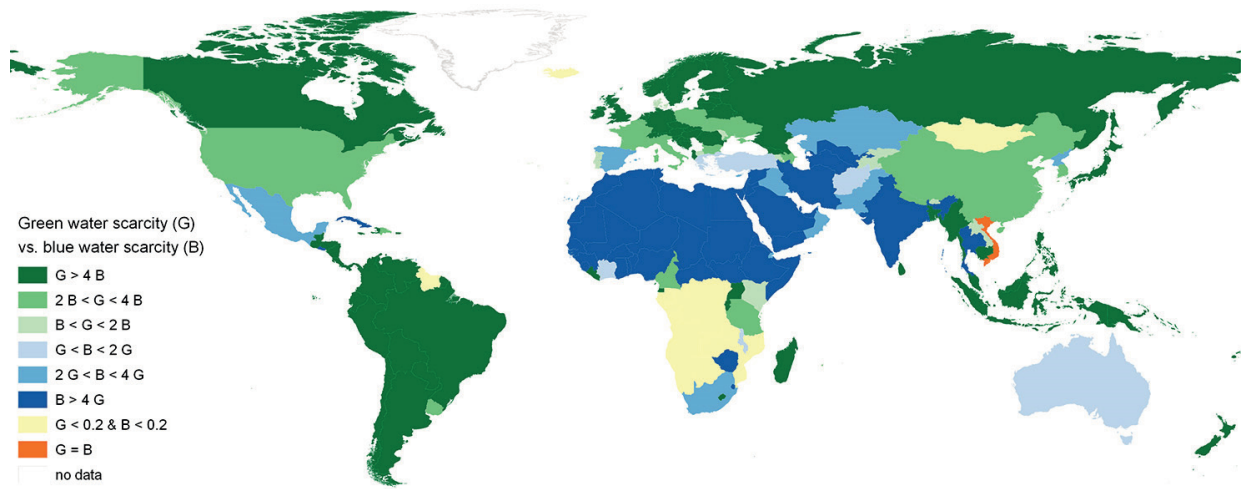

Figure 6-4. The ratio of green water scarcity to blue water scarcity per country. Green water scarcity is defined as the actual divided by the maximum sustainable green water footprint. Blue water scarcity is defined as the annual average of monthly ratios of actual to maximum sustainable blue water footprint (see Methods). In 12 countries both green and blue water scarcity are low (<0.2): Angola, Botswana, Congo, Congo (DRC), Gabon, Guyana, Iceland, Mongolia, Mozambique, Namibia, Suriname, and Zambia. In Vietnam, green and blue water scarcity are equally high (1.3). Out of the 150 countries remaining, green water is scarcer in 91 countries and blue water is scarcer in 59 countries.

Green water is scarcer than blue water in 91 out of 163 countries (Figure 6-4), meaning that the degree of human appropriation of sustainably available green water resources is larger than the degree of human appropriation of sustainably available blue water resources in those countries. While blue water scarcity is dominant in large parts of Africa, the Middle East, Ukraine, India, Mexico and several Mediterranean countries, 
green water is more than four times scarcer than blue water in South America, Canada, parts of Europe, Scandinavia, Russia and Southeast Asia.

An alarming $18 \%$ of $W F_{g}$ is in areas that should be set aside for nature to comply with ABT 11. This over-utilized green water flow $\left(1.8 \times 10^{3} \mathrm{~km}^{3} / \mathrm{y}\right)$ mainly concerns the $W F$ g of crop production (51\%) and grazing (35\%), followed by wood production $(11 \%)$ and urban areas (3\%). More than half the overshoot occurs in just ten countries: United States $(8.6 \%)$, Brazil $(6.9 \%)$, Indonesia (6.4\%), India (5.2\%), China (5.0\%), Colombia $(4.9 \%)$, Philippines (4.4\%), Mexico (4.0\%), Germany (3.2\%) and Malaysia (2.4\%). On the other hand, world-wide $9.5 \times 10^{3} \mathrm{~km}^{3} / \mathrm{y}$ of $W F_{\mathrm{g}, \mathrm{m}}$ is under-utilized, of which over half is located in just six countries: Russia (15.3\%), Brazil (9.9\%), Canada (8.0\%), United States $(7.5 \%)$, China (6.3\%) and Australia (6.3\%). In Russia, Canada and the United States, the underutilized flow predominantly indicates unleveraged potential for wood production, while in Brazil, China and Australia, livestock grazing could be intensified or expanded. Countries in which over-utilization exceeds under-utilization (Figure D-2, Appendix D.2) need to reduce their internal $W F_{g}$ in order to respect $W F_{g, m}$. In countries where overutilization is below under-utilization, increased use of the under-utilized flow could compensate for the green water resources that will no longer be available if priority areas for nature get fully protected. For maps of over- and under-utilization of the green water flow per purpose see Figures D-3 to D-6 (Appendix D.2).

\subsection{Discussion and Conclusions}

This first quantification of global green water scarcity is conservative for three reasons. First, although we applied several restrictions to identify non-utilized yet utilizable lands for crop cultivation, grazing or wood production, we may have overlooked other factors that prevent actual utilization (e.g. maintenance of local livelihoods or biodiversity). Our estimate of non-utilized yet utilizable land with at least moderate suitability for crop production $\left(306 \times 10^{6} \mathrm{ha}\right)$ is comparable to a previous global-scale estimate of unused potential cropland (Lambin \& Meyfroidt, 2011), but higher than when local trade-offs associated with land utilization are taken into account (Lambin et al., 2013). Second, we assume that intensification of livestock grazing and wood production is possible up to a maximum sustainable land utilization rate. However, there may be factors that limit increased utilization. For instance, in Namibia, livestock raising is constrained by a reliable source of drinking water rather than the quantity of forage (Sweet, 1998). Third, we set aside land for nature based on the map of global priority areas to achieve $17 \%$ of land protection (Pouzols et al., 2014). This map (Pouzols et al., 2014) reflects an efficient way of protecting biodiversity, since grid cells are 
prioritized based on conservation value. To achieve similar conservation value in a different, less efficient, configuration, probably more land would need to be protected, likely resulting in a smaller $P B_{g}$, more overshoot and higher $W S_{g}$ ratios. . In the end, the $W S_{\text {g }}$ ratio is the most sensitive to the land set aside for nature and the under-utilized green water flow, which in turn is mainly determined by maximum sustainable land utilization rates and the value of ecosystem services in grazing and forestry systems. We recommend future work that aims to improve upon our first estimate of green water scarcity to focus on these areas.

Green water is allocated through land-use decisions, driven by a demand for biomassbased products. Such decisions are made for time horizons of several years and are generally a matter of national concern. We therefore measured $W S_{g}$ at the country scale for a ten-year average period, in contrast to blue water scarcity, which is best measured month-by-month at the catchment scale or smaller (Mekonnen \& Hoekstra, 2016). The comparison of the degree of green versus blue water scarcity in Figure 6-4 should not be interpreted in terms of one being more important (e.g. having more impact) than the other. The impact of $1 \mathrm{~m}^{3}$ of green water consumed cannot easily be compared to the impact of $1 \mathrm{~m}^{3}$ of blue water consumed, even not when it is in the same catchment area. Impact is subject to the way it is defined and the local context. Increasing blue water scarcity, defined as the ratio of blue water consumption to blue water availability in a certain restricted geographic area and time period, generally translates to reduced river flows and declining groundwater, river and lake levels, which affects ecosystems and people depending on these flows and levels. Growing blue water scarcity also results in larger competition over blue water resources. Increasing green water scarcity implies that less and less green water resources are left to natural vegetation and that competition over green water resources is increasing. The combination of blue and green water scarcity limit the amount of food, feed, fibre and bio-energy that can be produced. Over-utilization of blue water threatens aquatic biodiversity and over-use of green water threatens terrestrial biodiversity; the precise impact depends in both cases on the local context. The existing biodiversity determines the potential impact of the over-use. For example, in heavily regulated rivers, not so rich in biodiversity anymore, additional abstraction of blue water for increased production on irrigated cropland, will have less environmental impact compared to grabbing some additional green water flow by converting a natural grassland into rain-fed agriculture (to achieve a similar production increase). Hydrological impacts of blue or green water use are different as well. Blue water use has a direct hydrological impact, because blue water that is used turns into 
evaporation, and blue water that is not used remains in the river. In the case of green water used or not used, in both cases we talk about evaporation and the hydrological impact is generally marginal (only the difference between natural evaporation versus cropland evaporation). This paper is not about hydrological or biodiversity impacts, but about water scarcity (\% of appropriation of limited water resources availability).

Our results demonstrate that many regions have no or very limited potential remaining to allocate more green water to the production of food, feed, fibre, timber and bioenergy. This has implications for both local economies and the global economy as a whole. For a sustainable future, overshoot should be prevented and the green water resources below the maximum sustainable level should be used as productive as possible. This requires protection of sufficient lands and associated green water flows for nature and a contraction of human activities in areas with high conservation value. Regions with a large under-utilized green water flow could exploit that potential and play an important role in meeting the future demand for biomass-based products. Efficient use of green water requires increased water and land productivities in agricultural and forestry systems (Foley et al., 2011) through management of the full range of ecosystem services along the lines of sustainable intensification (Rockström et al., 2017). 


\section{Conclusion}

The goal of this thesis is to broaden the discourse on freshwater scarcity in two respects. First, by assessing how Water Footprint Assessment (WFA) for a country can contribute to more sustainable and efficient allocation of blue water resources. Second, by assessing the allocation of the world's green water resources with respect to maximum sustainable levels.

\subsection{Insights from Water Footprint Assessment to Enrich National Policies to Manage Blue Water Scarcity}

Based on case studies for Morocco (Chapter 2) and Jordan (Chapter 3), I conclude that existing national policies for sustainable and efficient use of blue water resources can be enriched by WFA.

First, WFA feeds discussion on whether water is efficiently allocated, by showing the water footprint of end-purposes and the associated economic value:

- In Morocco, the crops that have the largest water and land footprints in absolute terms, have the lowest economic water $\left(\mathrm{US} \$ / \mathrm{m}^{3}\right)$ and land (US\$/ha) productivities, respectively. Such an analysis can illustrate the degree of (dis)alignment between policies on water and agriculture.

- Analysis of virtual water exports discloses the (implicit) water allocation to products destined for foreign consumers and feeds a debate on whether the generated income outweighs the (increased) costs induced by internal water scarcity and pollution.

Second, WFA can provide enriching insights in pressures on blue water resources:

- Water pollution aggravates blue water scarcity in Morocco and Jordan to a degree that is made explicit by the grey water footprint, which measures the volume of water needed to assimilate pollutants to meet ambient water quality standards.

- Analysis of the total blue water footprint in a basin versus blue water availability per month, reveals that blue water scarcity is particularly high in several months of the year in Morocco - which is masked when the analysis is done per year (as is common practice) - and helps target measures to reduce blue water scarcity when the largest water consumers in these months are identified. 
Third, WFA reveals options to reduce water demand by changing production and consumption patterns, which can lead to significant savings compared to traditional measures considered in water management:

- Compared to traditional water supply increasing measures planned for Morocco, large potential water savings are associated with lowering crop water footprints to benchmark levels and relocation of crop production based on spatial differences in water footprints.

- Campaigns aimed at reducing the water footprint of the diet of Jordanians are potentially much more effective in reducing blue water scarcity than those targeting the water use at home.

Fourth, WFA emphasizes the risks of being dependent on natural resources outside the country's borders:

- Analysis of virtual water imports, reveals a country's dependency on foreign water resources with associated risks, which can be mitigated in a sustainable manner by diversifying imports over various trade partners that are under a lower degree of water scarcity than the country itself.

- Desalination and bulk water transfer projects require careful consideration of their energy supply to avoid increased dependency on fossil and/or foreign energy sources.

The assessments for Morocco and Jordan have shown that sustainable and efficient allocation of blue water resources requires integrated policies on water, agriculture, energy and trade. Moreover, I found that even in semi-arid countries like Morocco and Jordan, which strongly depend on blue water resources, the largest share of the internal water footprint is green.

\subsection{Insights from a First Assessment of Green Water Scarcity}

Based on a literature review on the concept of green water scarcity and a classification of existing indicators of green water availability and scarcity (Chapter 4), I have argued that green water is a scarce resource and that appropriate indicators to assess green water scarcity are absent.

Subsequently, in a first time assessment of green water scarcity, I have shown how the world's limited green water resources are allocated to different purposes and where we approach or overshoot maximum sustainable levels (Chapter 6). This assessment required global gridded estimates of green water footprints associated with crop 
production, wood production, livestock grazing and urban areas. These were only available for crop production. Estimates for the other three purposes have been added in this research (Chapters 5 and 6).

The main insights from assessing the allocation of the world's green water resources with respect to maximum sustainable levels are:

- Humanity is closer to the planetary boundary for green water $(56 \%$ appropriation) than for blue water (27-54\% appropriation);

- Green water is scarcer than blue water in 91 out of 163 countries;

- Human's green water footprint is close to or beyond the maximum sustainable level in Europe, Central America, the Middle East and South Asia;

- Globally, $18 \%$ of the green water footprint is in areas to be reserved for nature.

For a sustainable future, overshoot should be prevented and the green water resources below the maximum sustainable level should be used as productive as possible. This requires protection of lands, contraction of activities in areas with high conservation value and efficient production systems with increased water and land productivities through management of the full range of ecosystem services along the lines of sustainable intensification.

\subsection{Recommendations for Further Research}

This research has triggered several questions for further research:

- Reducing crop water footprints to benchmark levels seems to be a promising option to significantly reduce the agricultural water footprint, however: How can reasonable benchmarks be developed and complied to, considering varying agroclimatic conditions in space and time as well as investment constraints?

- Integrated policies on water, agriculture, energy and trade are key to achieving sustainable water use, though: What are efficient organizational/institutional structures to enhance this?

- The challenge is to increase water and land productivities in agricultural and forestry systems, while at the same time managing the generation of other ecosystem services in these systems. Key here is to understand: What is the relationship between increased productivity and the generation of other ecosystem services? What are the main factors determining this relationship and how case-specific are they?

- Both green and blue water consumption are approaching the planetary boundaries on green and blue water, respectively. Yet there are spatial 
differences in the degrees of blue and green water scarcity, so: To which extent can we reduce blue water consumption in blue water-scarce areas by increased production in areas with an under-utilized green water flow, and vice versa?

- Green water scarcity has been assessed for the current situation, but: How do future scenarios regarding population growth, land-use change, change in consumption and production patterns, technology development and climate change affect green water scarcity?

\subsection{Final Remarks}

Dealing with freshwater scarcity requires sustainable and efficient allocation of blue and green water resources. This research has shown that national policies to manage blue water scarcity can be enriched by detailed analysis of the human water footprint within a country and thorough assessment of the virtual water flows leaving and entering a country. I hope that more and more countries will develop coherent inter-sectoral policies in a strive for sustainable and efficient water use, informed by assessments that broaden the scope of traditional water management. Furthermore, by quantifying the limits to green water availability, the main source of water to produce food, feed, fibre, timber and bio-energy, this research emphasizes the critical role green water has to play in the discourse on freshwater scarcity. To date, green water scarcity did not receive the attention it deserves. I hope this research triggers more scientific attention for the topic and puts it on the radar of policy makers. 


\section{List of References}

Abdulla, F., Eshtawi, T. \& Assaf, H. (2009) Assessment of the impact of potential climate change on the water balance of a semi-arid watershed, Water Resources Management, 23(10): 2051-2068.

Abdulla, F.A. \& Al-Shareef, A.W. (2009) Roof rainwater harvesting systems for household water supply in Jordan, Desalination, 243(1-3): 195-207.

Abu-Shams, I. \& Rabadi, A. (2003) The strategy of restructuring and rehabilitating the Greater Amman water network, International Journal of Water Resources Development, 19(2): 173-183.

Abu-Sharar, T., Al-Karablieh, E. \& Haddadin, M. (2012) Role of virtual water in optimizing water resources management in Jordan, Water Resources Management, 26(14): 3977-3993.

Abu Ghazleh, S., Hartmann, J., Jansen, N. \& Kempe, S. (2009) Water input requirements of the rapidly shrinking Dead Sea, Naturwissenschaften, 96(5): 637-643.

Abu Qdais, H. (2008) Environmental impacts of the mega desalination project: the RedDead Sea conveyor, Desalination, 220(1-3): 16-23.

Achilli, L. (2015) Syrian refugees in Jordan: a reality check, European University Institute: Florence, Italy, $12 \mathrm{pp}$.

Al-Ansari, N., Alibrahiem, N., Alsaman, M. \& Knutsson, S. (2014) Water demand management in Jordan, Engineering, 6: 19-26.

Al-Bakri, J.T., Salahat, M., Suleiman, A., Suifan, M., Hamdan, M.R., Khresat, S. \& Kandakji, T. (2013) Impact of climate and land use changes on water and food security in Jordan: implications for transcending "the tragedy of the commons", Sustainability, 5(2): 724-748.

Al-Karablieh, E.K., Salman, A.Z., Al-Omari, A.S., Wolff, H.-P. \& Anton, T. (2012) Estimation of the economic value of irrigation water in Jordan, Journal of Agricultural Science and Technology, 2: 487-497.

Al-Khalidi, S. (2015) Jordan, Israel agree $\$ 900$ million Red Sea-Dead Sea project, available at: http://www.reuters.com/article/2015/02/26/us-mideast-economy-wateridUSKBNOLU23Z20150226 (accessed on 7 May 2015).

Al-Omari, A., Salman, A. \& Karablieh, E. (2013) The Red Dead canal project: an adaptation option to climate change in Jordan, Desalination and Water Treatment, 52(13-15): 2833-2840.

Al-Omari, A.S., Al-Karablieh, E.K., Al-Houri, Z.M., Salman, A.Z. \& Al-Weshah, R.A. (2015) Irrigation water management in the Jordan valley under water scarcity, Fresenius Environmental Bulletin, 24(4): 1176-1188.

Al-Taani, A. (2013) Seasonal variations in water quality of Al-Wehda dam north of Jordan and water suitability for irrigation in summer, Arabian Journal of Geosciences, 6(4): 1131-1140.

Al-Taiee, T.M. (2012) Groundwater dams: a promise option for sustainable development of water resources in arid and semi-arid regions. In: Proceedings of the second international conference on integrated water resources management and challenges of the sustainable development, Agadir, Morocco, 24-26 March 2010, IHP-VII series on groundwater no. 4, UNESCO: Paris, France, 35-41. 
Al-Weshah, R.A. (2000) Optimal use of irrigation water in the Jordan Valley: a case study, Water Resources Management, 14(5): 327-338.

Al-Zu'bi, Y. (2007) Effect of irrigation water on agricultural soil in Jordan valley: an example from arid area conditions, Journal of Arid Environments, 70(1): 63-79.

Alcamo, J., Döll, P., Henrichs, T., Kaspar, F., Lehner, B., RöSch, T. \& Siebert, S. (2003) Global estimates of water withdrawals and availability under current and future "business-as-usual" conditions, Hydrological Sciences Journal, 48(3): 339348.

Aldaya, M.M., Garrido, A., Llamas, M.R., Varela-Ortega, C., Novo, P. \& Casado, R.R. (2010a) Water footprint and virtual water trade in Spain. In: Garrido, A. \& Aldaya, M.M. (eds.) Water Policy in Spain, CRC Press: Leiden, the Netherlands, 49-59.

Aldaya, M.M., Martínez-Santos, P. \& Llamas, M.R. (2010b) Incorporating the water footprint and virtual water into policy: reflections from the Mancha Occidental region, Spain, Water Resources Management, 24(5): 941-958.

Alfarra, A., Kemp-Benedict, E., Hötzl, H., Sader, N. \& Sonneveld, B. (2011) A framework for wastewater reuse in Jordan: utilizing a modified wastewater reuse index, Water Resources Management, 25(4): 1153-1167.

Allan, J.A. (2002) Hydro-peace in the Middle East: why no water wars?: a case study of the Jordan river basin, SAIS review, 22(2): 255-272.

Allen, R.G., Pereira, L.S., Raes, D. \& Smith, M. (1998) Crop evapotranspiration: guidelines for computing crop water requirements, FAO Irrigation and Drainage Paper 56, FAO: Rome, Italy, available at: http://www.fao.org/docrep/X0490E/X0490E00.htm.

Alley, W.M. (1984) The Palmer drought severity index - limitations and assumptions, Journal of Climate and Applied Meteorology, 23(7): 1100-1109.

Alqadi, K.A. \& Kumar, L. (2011) Water issues in the Kingdom of Jordan: a brief review with reasons for declining quality, Journal of Food Agriculture E Environment, 9(3-4): 1019-1023.

Alqadi, K.A. \& Kumar, L. (2013) Are there monthly variations in water quality in the Amman, Zarqa and Balqa regions, Jordan?, Computational Water, Energy, and Environmental Engineering, 2: 26-35.

Alqadi, K.A. \& Kumar, L. (2014) Water policy in Jordan, International Journal of Water Resources Development, 30(2): 322-334.

Alqadi, K.A., Kumar, L. \& Khormi, H.M. (2014) Mapping hotspots of underground water quality based on the variation of chemical concentration in Amman, Zarqa and Balqa regions, Jordan, Environmental Earth Sciences, 71(5): 2309-2317.

American Meteorological Society (2013) Drought: an information statement of the American Meteorological Society, American Meteorological Society: Boston, USA, 5 pp.

Ammari, T.G., Tahhan, R., Abubaker, S., Al-Zu'Bi, Y., Tahboub, A., Ta'Any, R., AbuRomman, S., Al-Manaseer, N. \& Stietiya, M.H. (2013) Soil salinity changes in the Jordan Valley potentially threaten sustainable irrigated agriculture, Pedosphere, 23(3): 376-384.

Ammary, B.Y. (2007) Wastewater reuse in Jordan: present status and future plans, Desalination, 211(1-3): 164-176. 
Amnesty International (2014) Left out in the cold: Syrian refugees abandoned by the international community, Amnesty International Ltd: London, UK, $44 \mathrm{pp}$.

Anderson, M.C., Norman, J.M., Mecikalski, J.R., Otkin, J.A. \& Kustas, W.P. (2007a) A climatological study of evapotranspiration and moisture stress across the continental United States based on thermal remote sensing: 1. model formulation, Journal of Geophysical Research-Atmospheres, 112: D10112.

Anderson, M.C., Norman, J.M., Mecikalski, J.R., Otkin, J.A. \& Kustas, W.P. (2007b) A climatological study of evapotranspiration and moisture stress across the continental United States based on thermal remote sensing: 2. surface moisture climatology, Journal of Geophysical Research-Atmospheres, 112: D10117.

Aulong, S., Bouzit, M. \& Doerfliger, N. (2009) Cost-effectiveness analysis of water management measures in two river basins of Jordan and Lebanon, Water Resources Management, 23(4): 731-753.

Batarseh, M., Rawajfeh, A., Ioannis, K. \& Prodromos, K. (2011) Treated municipal wastewater irrigation impact on olive trees (Olea Europaea L.) at Al-Tafilah, Jordan, Water, Air, E Soil Pollution, 217(1-4): 185-196.

Bates, C.G. (1935) Climatic characteristics of the Plains region. In: Silcox, F.A. (ed.) Possibilities of shelterbelt planting in the Plains region, United States Government: Washington, D.C., USA, 83-110.

Baudron, F. \& Giller, K.E. (2014) Agriculture and nature: trouble and strife?, Biological Conservation, 170(0): 232-245.

Bauhus, J., Puettmann, K. \& Messier, C. (2009) Silviculture for old-growth attributes, Forest Ecology and Management, 258(4): 525-537.

Baumgärtner, S., Becker, C., Faber, M. \& Manstetten, R. (2006) Relative and absolute scarcity of nature: assessing the roles of economics and ecology for biodiversity conservation, Ecological Economics, 59(4): 487-498.

Becker, N., Helgeson, J. \& Katz, D. (2014) Once there was a river: a benefit-cost analysis of rehabilitation of the Jordan river, Regional Environmental Change, 14(4): 13031314.

Bergman, K.H., Sabol, P. \& Miskus, D. (1988) Experimental indices for monitoring global drought conditions. In: Proceedings of the 13th annual climate diagnostics workshop, Cambridge, MA, USA, 31 October-4 November 1988, 190-197.

Beyth, M. (2007) The Red Sea and the Mediterranean-Dead Sea canal project, Desalination, 214(1-3): 365-371.

Bhalme, H.N. \& Mooley, D.A. (1980) Large-scale droughts/floods and monsoon circulation, Monthly Weather Review, 108(8): 1197-1211.

Blanchez, J. (1997) Forest resources and roundwood supply in the Asia Pacific countries: situation and outlook to the year 2010, Asia-Pacific forestry towards 2010, AsiaPacific Forestry Sector Outlook Study Working Paper Series, FAO: Rome, Italy, $151 \mathrm{pp}$.

Blumenstock, G. (1942) Drought in the United States analyzed by means of the theory of probability, USDA Technical Bulletins No. 819, USDA: Washington, D.C., USA, 63 pp.

Bouwman, A.F., Van der Hoek, K.W., Eickhout, B. \& Soenario, I. (2005) Exploring changes in world ruminant production systems, Agricultural Systems, 84(2): 121153. 
Brooks, T.M. (2014) Conservation: mind the gaps, Nature, 516(7531): 336-337.

Brown, C. (2000) The global outlook for future wood supply from forest plantations, Forestry Policy and Planning Division, FAO: Rome, Italy, $126 \mathrm{pp}$.

Brown, J.F., Wardlow, B.D., Tadesse, T., Hayes, M.J. \& Reed, B.C. (2008) The vegetation drought response index (VegDRI): a new integrated approach for monitoring drought stress in vegetation, Giscience E Remote Sensing, 45(1): 16-46.

Budyko, M.I. (1958) The heat balance of the earth's surface, US Dept. of Commerce, Weather Bureau: Washington, D.C., USA, 259 pp.

Butchart, S.H.M., Clarke, M., Smith, R.J., Sykes, R.E., Scharlemann, J.P.W., Harfoot, M., Buchanan, G.M., Angulo, A., Balmford, A., Bertzky, B., Brooks, T.M., Carpenter, K.E., Comeros-Raynal, M.T., Cornell, J., Ficetola, G.F., Fishpool, L.D.C., Fuller, R.A., Geldmann, J., Harwell, H., Hilton-Taylor, C., Hoffmann, M., Joolia, A., Joppa, L., Kingston, N., May, I., Milam, A., Polidoro, B., Ralph, G., Richman, N., Rondinini, C., Segan, D.B., Skolnik, B., Spalding, M.D., Stuart, S.N., Symes, A., Taylor, J., Visconti, P., Watson, J.E.M., Wood, L. \& Burgess, N.D. (2015) Shortfalls and solutions for meeting national and global conservation area targets, Conservation Letters, 8(5): 329-337.

Byun, H.-R. \& Wilhite, D.A. (1999) Objective quantification of drought severity and duration, Journal of Climate, 12(9): 2747-2756.

Canadell, J., Jackson, R.B., Ehleringer, J.B., Mooney, H.A., Sala, O.E. \& Schulze, E.-D. (1996) Maximum rooting depth of vegetation types at the global scale, Oecologia, 108(4): 583-595.

Capot-Rey, R. (1951) Une carte de l'indice d'aridité au Sahara français, Bulletin de l'Association de géographes français, 216-217: 73-76.

Carr, G. \& Potter, R.B. (2013) Towards effective water reuse: drivers, challenges and strategies shaping the organisational management of reclaimed water in Jordan, The Geographical Journal, 179(1): 61-73.

Carr, G., Potter, R.B. \& Nortcliff, S. (2011) Water reuse for irrigation in Jordan: perceptions of water quality among farmers, Agricultural Water Management, 98(5): 847-854.

Chahed, J., Besbes, M. \& Hamdane, A. (2011) Alleviating water scarcity by optimizing "green virtual-water": the case of Tunisia. In: Hoekstra, A.Y., Aldaya, M.M. \& Avril, B. (eds.) Proceedings of the ESF strategic workshop on accounting for water scarcity and pollution in the rules of international trade, Amsterdam, the Netherlands, 25-26 November 2010, Value of Water Research Report Series No. 54, UNESCO-IHE: Delft, the Netherlands, 99-113.

Chapagain, A.K. \& Hoekstra, A.Y. (2003) Virtual water flows between nations in relation to trade in livestock and livestock products, Value of Water Research Report Series No. 13, UNESCO-IHE: Delft, the Netherlands, 60 pp.

Chave, J., Coomes, D., Jansen, S., Lewis, S.L., Swenson, N.G. \& Zanne, A.E. (2009) Towards a worldwide wood economics spectrum, Ecology Letters, 12(4): 351-366.

Chini, L.P., Hurtt, G.C. \& Frolking, S. (2014) Harmonized global land use for years 15002100 (V1), ORNL Distributed Active Archive Center, http://dx.doi.org/10.3334/ORNLDAAC/1248. 
Chiu, Y.-W. \& Wu, M. (2013) The water footprint of biofuel produced from forest wood residue via a mixed alcohol gasification process, Environmental Research Letters, 8(3): 035015.

Chukalla, A.D., Krol, M.S. \& Hoekstra, A.Y. (2015) Green and blue water footprint reduction in irrigated agriculture: effect of irrigation techniques, irrigation strategies and mulching, Hydrology and Earth System Sciences, 19(12): 4877-4891.

Comair, G.F., Gupta, P., Ingenloff, C., Shin, G. \& McKinney, D.C. (2013) Water resources management in the Jordan river basin, Water and Environment Journal, 27(4): 495504.

Convention on Biological Diversity (2010) Conference of the parties decision X/2: the strategic plan for biodiversity 2011-2020 and the Aichi Biodiversity Targets, Nagoya, Japan, 18-29 October 2010, available at: http://www.cbd.int/doc/decisions/cop-10/cop-10-dec-02-en.pdf (accessed on 4 May 2015).

Costanza, R., d'Arge, R., de Groot, R., Farber, S., Grasso, M., Hannon, B., Limburg, K., Naeem, S., O'Neill, R.V., Paruelo, J., Raskin, R.G., Sutton, P. \& van den Belt, M. (1997) The value of the world's ecosystem services and natural capital, Nature, 387(6630): 253-260.

Costanza, R., de Groot, R., Braat, L., Kubiszewski, I., Fioramonti, L., Sutton, P., Farber, S. \& Grasso, M. (2017) Twenty years of ecosystem services: how far have we come and how far do we still need to go?, Ecosystem Services, 28(Part A): 1-16.

Costanza, R., de Groot, R., Sutton, P., van der Ploeg, S., Anderson, S.J., Kubiszewski, I., Farber, S. \& Turner, R.K. (2014) Changes in the global value of ecosystem services, Global Environmental Change, 26: 152-158.

Dammer, L., Bowyer, C., Breitmayer, E., Eder, A., Nanni, S., Allen, B., Carus, M. \& Essel, R. (2016) Mapping study on cascading use of wood products, WWF: Gland, Switzerland, $55 \mathrm{pp}$.

De Chatel, F. (2014) The role of drought and climate change in the Syrian uprising: untangling the triggers of the revolution, Middle Eastern Studies, 50(4): 521-535.

De Fraiture, C., Wichelns, D., Rockstrom, J., Kemp-Benedict, E., Eriyagama, N., Gordon, L.J., Hanjra, M.A., Hoogeveen, J., Huber-Lee, A. \& Karlberg, L. (2007) Looking ahead to 2050: scenarios of alternative investment approaches, International Water Management Institute: Colombo, Sri Lanka.

De Graaf, I.E.M., van Beek, L.P.H., Wada, Y. \& Bierkens, M.F.P. (2014) Dynamic attribution of global water demand to surface water and groundwater resources: effects of abstractions and return flows on river discharges, Advances in Water Resources, 64: 21-33.

De Lannoy, G.J.M., Koster, R.D., Reichle, R.H., Mahanama, S.P.P. \& Liu, Q. (2014) An updated treatment of soil texture and associated hydraulic properties in a global land modeling system, Journal of Advances in Modeling Earth Systems, 6(4): 957-979.

De Martonne, E. (1942) Nouvelle carte mondial de l'indice d'aridité, Annales de Géographie, 288: 241-250.

Döll, P., Hoffmann-Dobrev, H., Portmann, F.T., Siebert, S., Eicker, A., Rodell, M., Strassberg, G. \& Scanlon, B.R. (2012) Impact of water withdrawals from 
groundwater and surface water on continental water storage variations, Journal of Geodynamics, 59-60: 143-156.

Doppler, W., Salman, A.Z., Al-Karablieh, E.K. \& Wolff, H.-P. (2002) The impact of water price strategies on the allocation of irrigation water: the case of the Jordan Valley, Agricultural Water Management, 55(3): 171-182.

Dottridge, J. \& Abu Jaber, N. (1999) Groundwater resources and quality in northeastern Jordan: safe yield and sustainability, Applied Geography, 19(4): 313-323.

Du, L., Tian, Q., Yu, T., Meng, Q., Jancso, T., Udvardy, P. \& Huang, Y. (2013) A comprehensive drought monitoring method integrating MODIS and TRMM data, International Journal of Applied Earth Observation and Geoinformation, 23: 245253.

Eitelberg, D.A., van Vliet, J. \& Verburg, P.H. (2015) A review of global potentially available cropland estimates and their consequences for model-based assessments, Global Change Biology, 21(3): 1236-1248.

El-Naqa, A. \& Al-Shayeb, A. (2009) Groundwater protection and management strategy in Jordan, Water Resources Management, 23(12): 2379-2394.

Ellison, D., N Futter, M. \& Bishop, K. (2012) On the forest cover-water yield debate: from demand- to supply-side thinking, Global Change Biology, 18(3): 806-820.

Erb, K.-H., Gaube, V., Krausmann, F., Plutzar, C., Bondeau, A. \& Haberl, H. (2007) A comprehensive global $5 \mathrm{~min}$ resolution land-use data set for the year 2000 consistent with national census data, Journal of Land Use Science, 2(3): 191-224.

Erb, K.-H., Haberl, H., Krausmann, F., Lauk, C., Plutzar, C., Steinberger, J.K., Müller, C., Bondeau, A., Waha, K. \& Pollack, G. (2009) Eating the planet: feeding and fuelling the world sustainably, fairly and humanely - a scoping study. Social Ecology Working Paper 116. Institute of Social Ecology: Vienna, Austria, 132 pp.

Falk, R.F. \& McKeever, D.B. (2004) Recovering wood for reuse and recycling: a United States perspective. In: Gallis, C. (ed.) Proceedings of the European COST E31 conference on management of recovered wood recycling, bioenergy and other options, Thessaloniki, Greece, 22-24 April 2004, 29-40.

Falkenmark, M. (1995) Land-water linkages: a synopsis, Land and water integration and river basin management, FAO: Rome, Italy, 15-16.

Falkenmark, M. (2000) Competing freshwater and ecological services in the river basin perspective, Water International, 25(2): 172-177.

Falkenmark, M. (2003) Freshwater as shared between society and ecosystems: from divided approaches to integrated challenges, Philosophical Transactions of the Royal Society of London Series B-Biological Sciences, 358(1440): 2037-2049.

Falkenmark, M. (2013a) Growing water scarcity in agriculture: future challenge to global water security, Philosophical Transactions of the Royal Society a-Mathematical Physical and Engineering Sciences, 371: 20120410.

Falkenmark, M. (2013b) Water security - the multiform water scarcity. In: Lankford, B., Bakker, K., Zeitoun, M \& Conway, D. (eds.) Water Security: Principles, Perspectives and Practices, Earthscan: London, UK, 64-79.

Falkenmark, M., Berntell, A., Jägerskog, A., Lundqvist, J., Matz, M. \& Tropp, H. (2007) On the verge of a new water scarcity: a call for good governance and human ingenuity, SIWI: Stockholm, Sweden, $19 \mathrm{pp}$. 
Falkenmark, M., Lundqvist, J. \& Widstrand, C. (1989) Macro-scale water scarcity requires micro-scale approaches - aspects of vulnerability in semi-arid development, Natural Resources Forum, 13(4): 258-267.

Falkenmark, M. \& Rockström, J. (2004) Balancing Water for Humans and Nature: The New Approach in Ecohydrology, Earthscan: London, UK.

Falkenmark, M. \& Rockström, J. (2006) The new blue and green water paradigm: breaking new ground for water resources planning and management, Journal of Water Resources Planning and Management, 132(3): 129-132.

Falkenmark, M. \& Rockström, J. (2010) Building water resilience in the face of global change: from a blue-only to a green-blue water approach to land-water management, Journal of Water Resources Planning and Management, 136(6): 606610.

Fan, Y., Li, H. \& Miguez-Macho, G. (2013) Global Patterns of Groundwater Table Depth, Science, 339(6122): 940-943.

FAO (1986) Early agrometeorological crop yield assessment, FAO Plant Production and Protection Paper 73, FAO: Rome, Italy, $150 \mathrm{pp}$.

FAO (2004) Economic valuation of water resources in agriculture: from the sectoral to a functional perspective of natural resource management, FAO water reports 27, FAO: Rome, Italy, available at: http://www.fao.org/docrep/007/y5582e/y5582e00.htm.

FAO (2012a) AQUASTAT online database, Water resources, FAO: Rome, Italy, available at http://www.fao.org/nr/water/aquastat/water_res/index.stm (accessed on 5 May 2012).

FAO (2012b) Coping with water scarcity: an action framework for agriculture and food security, FAO water reports 38, FAO: Rome, Italy, 78 pp.

FAO (2013a) AQUASTAT online database, Country fact sheet: Morocco, FAO: Rome, Italy, available at: www.fao.org/nr/aquastat/ (accessed on 22 February 2013).

FAO (2013b) FAOSTAT online database, Producer prices - annual, FAO: Rome, Italy, available at: http://faostat.fao.org (accessed on 6 July 2013).

FAO (2013c) AQUASTAT online database, geo-referenced database of African dams, FAO: Rome, Italy, available at: http://www.fao.org/nr/water/aquastat/dams/region/D_Africa.xlsx (accessed on 28 March 2013).

FAO (2013d) Global map of monthly reference evapotranspiration - 10 arc minutes, GeoNetwork: grid database, FAO: Rome, Italy, available at: www.fao.org/geonetwork/srv/en/resources.get?id = 7416\&fname = ref_evap_fao_10min.zip\&access = private (accessed on 19 March 2013).

FAO (2014) AQUASTAT online database, Country fact sheet: Jordan, FAO: Rome, Italy, available at: www.fao.org/nr/aquastat/ (accessed on 6 November 2014).

FAO (2015a) AQUASTAT online database, Glossary, FAO: Rome, Italy available at: http://www.fao.org/nr/water/aquastat/data/glossary/search.html?lang=en (accessed on 17 July 2015).

FAO (2015b) FAOSTAT online database, Trade, FAO: Rome, Italy, available at: http://faostat.fao.org (accessed on 5 January 2015).

FAO (2016a) FAOSTAT online database, Crops primary, FAO: Rome, Italy, available at: http://faostat.fao.org (accessed on 8 February 2016). 
FAO (2016b) FAOSTAT online database, Forestry production, FAO: Rome, Italy, available at: http://faostat.fao.org (accessed on 29 July 2016).

FAO (2016c) FAOSTAT online database, Livestock primary, FAO: Rome, Italy, available at: http://faostat.fao.org (accessed on 27 October 2016).

FAO (2016d) FAOSTAT online database, Producer prices - annual, FAO: Rome, Italy, available at http://faostat3.fao.org/download/P/PP/E (accessed on 11 October 2016).

Fekete, B.M., Vörösmarty, C.J. \& Grabs, W. (2002) High-resolution fields of global runoff combining observed river discharge and simulated water balances, Global Biogeochemical Cycles, 16(3): 15-1-15-10.

Foley, J.A., Ramankutty, N., Brauman, K.A., Cassidy, E.S., Gerber, J.S., Johnston, M., Mueller, N.D., O'Connell, C., Ray, D.K., West, P.C., Balzer, C., Bennett, E.M., Carpenter, S.R., Hill, J., Monfreda, C., Polasky, S., Rockstrom, J., Sheehan, J., Siebert, S., Tilman, D. \& Zaks, D.P.M. (2011) Solutions for a cultivated planet, Nature, 478(7369): 337-342.

Friedl, M.A. \& Sulla-Menashe, D. (2015) MCD12C1 MODIS/Terra+Aqua Land Cover Type Yearly L3 Global 0.05Deg CMG (Version 051). NASA EOSDIS Land Processes DAAC, USGS EROS Center, http://dx.doi.org/10.5067/MODIS/MCD12C1.006.

Friedl, M.A., Sulla-Menashe, D., Tan, B., Schneider, A., Ramankutty, N., Sibley, A. \& Huang, X. (2010) MODIS collection 5 global land cover: algorithm refinements and characterization of new datasets, Remote Sensing of Environment, 114(1): 168182.

Fuller, R.A. \& Gaston, K.J. (2009) The scaling of green space coverage in European cities, Biology Letters, 5(3): 352.

Gao, B. (1996) NDWI - a normalized difference water index for remote sensing of vegetation liquid water from space, Remote Sensing of Environment, 58(3): 257266.

Gerten, D., Heinke, J., Hoff, H., Biemans, H., Fader, M. \& Waha, K. (2011) Global water availability and requirements for future food production, Journal of Hydrometeorology, 12(5): 885-899.

Gerten, D., Hoff, H., Bondeau, A., Lucht, W., Smith, P. \& Zaehle, S. (2005) Contemporary "green" water flows: simulations with a dynamic global vegetation and water balance model, Physics and Chemistry of the Earth, 30(6-7): 334-338.

Gerten, D., Hoff, H., Rockström, J., Jägermeyr, J., Kummu, M. \& Pastor, A.V. (2013) Towards a revised planetary boundary for consumptive freshwater use: role of environmental flow requirements, Current Opinion in Environmental Sustainability, 5(6): 551-558.

Gerten, D., Schaphoff, S. \& Lucht, W. (2007) Potential future changes in water limitations of the terrestrial biosphere, Climatic Change, 80(3-4): 277-299.

Ghulam, A., Qin, Q., Teyip, T. \& Li, Z.-L. (2007a) Modified perpendicular drought index (MPDI): a real-time drought monitoring method, ISPRS Journal of Photogrammetry and Remote Sensing, 62(2): 150-164.

Ghulam, A., Qin, Q. \& Zhan, Z. (2007b) Designing of the perpendicular drought index, Environmental Geology, 52(6): 1045-1052. 
Gleick, P.H. (2014) Water, drought, climate change, and conflict in Syria, Weather Climate and Society, 6(3): 331-340.

Gocic, M. \& Trajkovic, S. (2014) Drought characterisation based on water surplus variability index, Water Resources Management, 28(10): 3179-3191.

Goldsmith, E. \& Hildyard, N. (1984) Water losses: exceeding gains? In: The Social and Environmental Effects of Large Dams: Volume 1 Overview, Wadebridge Ecological Centre: Cornwall, UK.

Gommes, R.A. \& Petrassi, F. (1994) Rainfall variability and drought in Sub-Saharan Africa since 1960, Agrometeorology Series Working Paper 9, FAO: Rome, Italy, 100 pp.

Gorczynski, W. (1940) The aridity coefficient and its application to California, Technical Report, Scripps Institution of Oceanography, University of California: La Jolla, USA, 7 pp.

Gordon, L.J., Finlayson, C.M. \& Falkenmark, M. (2010) Managing water in agriculture for food production and other ecosystem services, Agricultural Water Management, 97(4): 512-519.

Gu, Y., Brown, J.F., Verdin, J.P. \& Wardlow, B. (2007) A five-year analysis of MODIS NDVI and NDWI for grassland drought assessment over the central Great Plains of the United States, Geophysical Research Letters, 34(6): L06407.

Hadadin, N., Qaqish, M., Akawwi, E. \& Bdour, A. (2010) Water shortage in Jordan sustainable solutions, Desalination, 250(1): 197-202.

Haddadin, M.J. (2003) Exogenous water: a conduit to globalization of water resources. In: Hoekstra, A.Y. (ed.) Virtual water trade: proceedings of the international expert meeting on virtual water trade, Value of Water Research Report Series No. 12, UNESCO-IHE: Delft, the Netherlands, 159-169.

Haddadin, M.J. (2009) Irrigation technology and water conservation in Jordan. In: Albiac, J. \& Dinar, A. (eds.) The Management of Water Quality and Irrigation Technologies, Earthscan: London, UK; Sterling, CA, USA, 137-152.

Haddadin, M.J. (2011) Water: triggering cooperation between former enemies, Water International, 36(2): 178-185.

Hanasaki, N., Inuzuka, T., Kanae, S. \& Oki, T. (2010) An estimation of global virtual water flow and sources of water withdrawal for major crops and livestock products using a global hydrological model, Journal of Hydrology, 384(3-4): 232244.

Hargreaves, G.H. (1972) The evaluation of water deficiencies, Age of Changing Priorities for Land and Water, ASCE irrigation and drainage specialty conference, Spokane, USA, 26-28 September 1972, 19 pp.

Hayes, M. (2007) Drought Indices, Intermountain West Climate Summary, Western Water Assessment: Colorado, USA, 2-6.

Heim, R.R. (2002) A review of twentieth-century drought indices used in the United States, Bulletin of the American Meteorological Society, 83(8): 1149-1165.

Hejazi, M., Edmonds, J., Clarke, L., Kyle, P., Davies, E., Chaturvedi, V., Wise, M., Patel, P., Eom, J., Calvin, K., Moss, R. \& Kim, S. (2014) Long-term global water projections using six socioeconomic scenarios in an integrated assessment modeling framework, Technological Forecasting and Social Change, 81(0): 205-226. 
Hiler, E.A. \& Clark, R.N. (1971) Stress day index to characterize effects of water stress on crop yields, Transactions of the American Society of Agricultural Engineers, 14(4): 757-761.

Hoekstra, A.Y. (ed.) (2003) Virtual water trade: proceedings of the international expert meeting on virtual water trade, Delft, the Netherlands, 12-13 December 2002, Value of Water Research Report Series No. 12, UNESCO-IHE: Delft, the Netherlands, 230 pp.

Hoekstra, A.Y. (2011) The global dimension of water governance: why the river basin approach is no longer sufficient and why cooperative action at global level is needed, Water, 3(1): 21.

Hoekstra, A.Y. (2013) The Water Footprint of Modern Consumer Society, Routledge: London, UK.

Hoekstra, A.Y. (2014) Sustainable, efficient, and equitable water use: the three pillars under wise freshwater allocation, Wiley Interdisciplinary Reviews: Water, 1(1): 3140.

Hoekstra, A.Y. (2017) Water footprint assessment: evolvement of a new research field, Water Resources Management, 31(10): 3061-3081.

Hoekstra, A.Y. \& Chapagain, A.K. (2007a) The water footprints of Morocco and the Netherlands: global water use as a result of domestic consumption of agricultural commodities, Ecological Economics, 64(1): 143-151.

Hoekstra, A.Y. \& Chapagain, A.K. (2007b) Water footprints of nations: water use by people as a function of their consumption pattern, Water Resources Management, 21(1): 35-48.

Hoekstra, A.Y. \& Chapagain, A.K. (2008) Globalization of Water: Sharing the Planet's Freshwater Resources, Blackwell Publishing: Oxford, UK.

Hoekstra, A.Y., Chapagain, A.K., Aldaya, M.M. \& Mekonnen, M.M. (2011) The Water Footprint Assessment Manual: Setting the Global Standard, Earthscan: London, UK.

Hoekstra, A.Y. \& Hung, P.Q. (2005) Globalisation of water resources: international virtual water flows in relation to crop trade, Global Environmental ChangeHuman and Policy Dimensions, 15(1): 45-56.

Hoekstra, A.Y. \& Mekonnen, M.M. (2012) The water footprint of humanity, Proceedings of the National Academy of Sciences, 109(9): 3232-3237.

Hoekstra, A.Y., Mekonnen, M.M., Chapagain, A.K., Mathews, R.E. \& Richter, B.D. (2012) Global monthly water scarcity: blue water footprints versus blue water availability, PLoS ONE, 7(2).

Hoekstra, A.Y. \& Wiedmann, T.O. (2014) Humanity's unsustainable environmental footprint, Science, 344(6188): 1114-1117.

Hoff, H., Falkenmark, M., Gerten, D., Gordon, L., Karlberg, L. \& Rockström, J. (2010) Greening the global water system, Journal of Hydrology, 384(3): 177-186.

Holzworth, D.P., Huth, N.I., de Voil, P.G., Zurcher, E.J., Herrmann, N.I., McLean, G., Chenu, K., van Oosterom, E.J., Snow, V., Murphy, C., Moore, A.D., Brown, H., Whish, J.P.M., Verrall, S., Fainges, J., Bell, L.W., Peake, A.S., Poulton, P.L., Hochman, Z., Thorburn, P.J., Gaydon, D.S., Dalgliesh, N.P., Rodriguez, D., Cox, H., Chapman, S., Doherty, A., Teixeira, E., Sharp, J., Cichota, R., Vogeler, I., Li, F.Y., Wang, E., Hammer, G.L., Robertson, M.J., Dimes, J.P., Whitbread, A.M., Hunt, J., van Rees, H., McClelland, T., Carberry, P.S., Hargreaves, J.N.G., 
MacLeod, N., McDonald, C., Harsdorf, J., Wedgwood, S. \& Keating, B.A. (2014) APSIM - Evolution towards a new generation of agricultural systems simulation, Environmental Modelling \& Software, 62: 327-350.

Huete, A., Justice, C. \& Liu, H. (1994) Development of vegetation and soil indices for MODIS-EOS, Remote Sensing of Environment, 49(3): 224-234.

Hunt, E.D., Hubbard, K.G., Wilhite, D.A., Arkebauer, T.J. \& Dutcher, A.L. (2009) The development and evaluation of a soil moisture index, International Journal of Climatology, 29(5): 747-759.

Hurtt, G.C., Chini, L.P., Frolking, S., Betts, R.A., Feddema, J., Fischer, G., Fisk, J.P., Hibbard, K., Houghton, R.A., Janetos, A., Jones, C.D., Kindermann, G., Kinoshita, T., Klein Goldewijk, K., Riahi, K., Shevliakova, E., Smith, S., Stehfest, E., Thomson, A., Thornton, P., van Vuuren, D.P. \& Wang, Y.P. (2011) Harmonization of land-use scenarios for the period 1500-2100: 600 years of global gridded annual land-use transitions, wood harvest, and resulting secondary lands, Climatic Change, 109(1): 117-161.

IIASA/FAO (2012) Global agro-ecological zones (GAEZ v3.0). IIASA/FAO: Laxenburg, Austria; Rome, Italy, 179 pp.

IPCC (2013) Summary for Policymakers. In: Stocker, T.F., Qin, D., Plattner, G.-K., Tignor, M., Allen, S.K., Boschung, J., Nauels, A., Xia, Y., Bex V. \& Midgley, P.M. (eds.) Climate change 2013: the physical science basis, Contribution of working group I to the fifth assessment report of the intergovernmental panel on climate change, Cambridge University Press: Cambridge, UK; New York, NY, USA, 329.

Isard, S.A., Welford, M.R. \& Hollinger, S.E. (1995) A simple soil moisture index to forecast crop yields, Physical Geography, 16(6): 524-538.

ITC (2007) SITA version 1996-2005 in SITC [DVD-ROM], International Trade Centre: Geneva, Switzerland.

IUCN \& UNEP-WCMC (2016) The world database on protected areas (WDPA), UNEPWCMC: Cambridge, UK, available at: www.protectedplanet.net (accessed on 5 May 2016).

Jaber, J.O. \& Mohsen, M.S. (2001) Evaluation of non-conventional water resources supply in Jordan, Desalination, 136(1-3): 83-92.

Jackson, R.D., Idso, S.B., Reginato, R.J. \& Pinter, P.J. (1981) Canopy temperature as a crop water-stress indicator, Water Resources Research, 17(4): 1133-1138.

Jenny, H. (1994) (first published in 1941) Factors of Soil Formation: A System of Quantitative Pedology, Dover Publication Inc.: New York, NY, USA, 191 pp.

JICA/MATEE/ABHT (2007) Etude du plan de gestion intégrée des ressources en eau dans la plaine du Haouz, Royaume du Maroc, Rapport intermédiaire, available at: http://eau-tensift.net/fileadmin/user_files/pdf/etudes/ JICA_ETUDE_PLAN_DE_GESTION_INTEGREE_RE_HAOUZ.pdf (accessed on 12 August 2013).

Jones, C.A., Dyke, P.T., Williams, J.R., Kiniry, J.R., Benson, V.W. \& Griggs, R.H. (1991) EPIC: An operational model for evaluation of agricultural sustainability, Agricultural Systems, 37(4): 341-350.

Jürgensen, C., Kollert, W. \& Lebedys, A. (2014) Assessment of industrial roundwood production from planted forests, Planted Forests and Trees Working Paper 
Series No. 48, FAO: Rome, Italy, available at: http://www.fao.org/forestry/plantedforests/67508@170537/en/ (accessed on 11 August 2016).

Kallis, G. (2008) Droughts, Annual Review of Environment and Resources, 33: 85-118.

Karl, T.R. (1986) The sensitivity of the Palmer drought severity index and Palmer's Zindex to their calibration coefficients including potential evapotranspiration, Journal of Climate and Applied Meteorology, 25(1): 77-86.

Kastner, T., Rivas, M.J.I., Koch, W. \& Nonhebel, S. (2012) Global changes in diets and the consequences for land requirements for food, Proceedings of the National Academy of Sciences, 109(18): 6868-6872.

Keenan, R.J., Reams, G.A., Achard, F., de Freitas, J.V., Grainger, A. \& Lindquist, E. (2015) Dynamics of global forest area: results from the FAO global forest resources assessment 2015, Forest Ecology and Management, 352: 9-20.

Keetch, J.J. \& Byram, G.M. (1968) A drought index for forest fire control, USDA Forest Service Research Paper SE-38, Southeastern Forest Experiment Station: Asheville, NC, USA, 33 pp.

Kehoe, L., Romero-Muñoz, A., Polaina, E., Estes, L., Kreft, H. \& Kuemmerle, T. (2017) Biodiversity at risk under future cropland expansion and intensification, Nature Ecology \& Evolution, 1(8): 1129-1135.

Kelley, C.P., Mohtadi, S., Cane, M.A., Seager, R. \& Kushnir, Y. (2015) Climate change in the Fertile Crescent and implications of the recent Syrian drought, Proceedings of the National Academy of Sciences, 112(11): 3241-3246.

Keyantash, J. \& Dracup, J.A. (2002) The quantification of drought: an evaluation of drought indices, Bulletin of the American Meteorological Society, 83(8): 1167-1180.

Kincer, J.B. (1919) The seasonal distribution of precipitation and its frequency and intensity in the United States, Monthly Weather Review, 47(9): 624-631.

Klein Goldewijk, K., Beusen, A., van Drecht, G. \& de Vos, M. (2011) The HYDE 3.1 spatially explicit database of human-induced global land-use change over the past 12,000 years, Global Ecology and Biogeography, 20(1): 73-86.

Kliot, N. (2005) Water Resources and Conflict in the Middle East, 5th ed., Routledge: Abingdon, UK.

Kogan, F.N. (1990) Remote-sensing of weather impacts on vegetation in nonhomogeneous areas, International Journal of Remote Sensing, 11(8): 1405-1419.

Kogan, F.N. (1995) Droughts of the late 1980s in the United-States as derived from NOAA polar-orbiting satellite data, Bulletin of the American Meteorological Society, 76(5): 655-668.

Kogan, F.N. (2001) Operational space technology for global vegetation assessment, Bulletin of the American Meteorological Society, 82(9): 1949-1964.

Köhl, M., Lasco, R., Cifuentes, M., Jonsson, Ö., Korhonen, K.T., Mundhenk, P., de Jesus Navar, J. \& Stinson, G. (2015) Changes in forest production, biomass and carbon: results from the 2015 UN FAO global forest resource assessment, Forest Ecology and Management, 352: 21-34.

Komatsu, H., Cho, J., Matsumoto, K. \& Otsuki, K. (2012) Simple modeling of the global variation in annual forest evapotranspiration, Journal of Hydrology, 420-421: 380390. 
Köppen, W. (1931) Grundriss der Klimakunde: Zweite, Verbesserte Auflage der Klimate der Erde, Walter de Gruyter \& Co: Berlin; Leipzig, Germany.

Kuemmerle, T., Erb, K., Meyfroidt, P., Müller, D., Verburg, P.H., Estel, S., Haberl, H., Hostert, P., Jepsen, M.R., Kastner, T., Levers, C., Lindner, M., Plutzar, C., Verkerk, P.J., van der Zanden, E.H. \& Reenberg, A. (2013) Challenges and opportunities in mapping land use intensity globally, Current Opinion in Environmental Sustainability, 5(5): 484-493.

Kummu, M., Gerten, D., Heinke, J., Konzmann, M. \& Varis, O. (2014) Climate-driven interannual variability of water scarcity in food production potential: a global analysis, Hydrology and Earth System Sciences, 18(2): 447-461.

Lambin, E.F., Gibbs, H.K., Ferreira, L., Grau, R., Mayaux, P., Meyfroidt, P., Morton, D.C., Rudel, T.K., Gasparri, I. \& Munger, J. (2013) Estimating the world's potentially available cropland using a bottom-up approach, Global Environmental Change, 23(5): 892-901.

Lambin, E.F. \& Meyfroidt, P. (2011) Global land use change, economic globalization, and the looming land scarcity, Proceedings of the National Academy of Sciences, 108(9): 3465-3472.

Lang, R. (1920) Verwitterung und Bodenbildung als Einführung in die Bodenkunde, Schweizerbart Science Publishers: Stuttgart, Germany.

Laouina, A. (2001) Compétition irrigation/eau potable en region de stress hydrique: le cas de la region d'Agadir (Maroc). In: Camarda, D. \& Grassini, L. (ed.) Interdependency between agriculture and urbanization: conflicts on sustainable use of soil and water. CIHEAM: Bari, Italy, 17-31, available at: ressources.ciheam.org/om/pdf/a44/02001585.pdf (accessed on 20 June 2013).

Launiainen, S., Futter, M.N., Ellison, D., Clarke, N., Finér, L., Högbom, L., Laurén, A. \& Ring, E. (2014) Is the water footprint an appropriate tool for forestry and forest products: the Fennoscandian case, Ambio, 43(2): 244-256.

Levers, C., Verkerk, P.J., Müller, D., Verburg, P.H., Butsic, V., Leitão, P.J., Lindner, M. \& Kuemmerle, T. (2014) Drivers of forest harvesting intensity patterns in Europe, Forest Ecology and Management, 315: 160-172.

Liu, J. \& Yang, H. (2010) Spatially explicit assessment of global consumptive water uses in cropland: green and blue water, Journal of Hydrology, 384(3-4): 187-197.

Liu, J., Zehnder, A.J.B. \& Yang, H. (2009) Global consumptive water use for crop production: the importance of green water and virtual water, Water Resources Research, 45: W05428.

Liu, Q., Yasufuku, N., Miao, J. \& Ren, J. (2014) An approach for quick estimation of maximum height of capillary rise, Soils and Foundations, 54(6): 1241-1245.

Loveland, T.R., Brown, J., Ohlen, D., Reed, B., Zhu, Z., Yang, L. \& Howard, S. (2009) ISLSCP II IGBP DISCover and SiB Land Cover, 1992-1993, ORNL Distributed Active Archive Center, http://dx.doi.org/10.3334/ORNLDAAC/930.

Lutz, J. (2011) How Trees Grow, Forest Research Notes, 8(2): 1-4.

Maracchi, G. 2000. Agricultural drought - a practical approach to definition, assessment and mitigation strategies. In: Vogt, J. \& Somma, F. (eds.) Drought and Drought Mitigation in Europe, Advances in Natural and Technological Hazards Research, Springer: Dordrecht, the Netherlands, 63-75.

Marcovitch, S. (1930) The measure of droughtiness, Monthly Weather Review, 58(3): 113. 
Marletto, V., Zinoni, F., Botarelli, L. \& Alessandrini, C. (2005) Studio dei fenomeni siccitosi in Emilia-Romagna con il modello di bilancio idrico criteria, RIAM, 9: 32-33.

Mathioudakis, V., Gerbens-Leenes, P.W., Van der Meer, T.H. \& Hoekstra, A.Y. (2017) The water footprint of second-generation bioenergy: a comparison of biomass feedstocks and conversion techniques, Journal of Cleaner Production, 148: 571582.

Matthews, E., Payne, R., Rohweder, M. \& Murray, S. (2000) Pilot Analysis of Global Ecosystems: Forest Ecosystems, World Resources Institute: Washington, D.C., USA, available at: http://www.wri.org/wr2000 (accessed on 16 September 2015).

McCown, R.L., Hammer, G.L., Hargreaves, J.N.G., Holzworth, D. \& Huth, N.I. (1995) APSIM: an agricultural production system simulation model for operational research, Mathematics and Computers in Simulation, 39(3-4): 225-231.

McGuire, J.K. \& Palmer, W.C. (1957) The 1957 drought in the Eastern United States, Monthly Weather Review, 85(9): 305-314.

McKee, T.B., Doesken, N.J. \& Kleist, J. (1993) The relationship of drought frequency and duration to time scales. In: Proceedings of the 8th conference on applied climatology, Anaheim, CA, USA ,17-22 January 1993 Anaheim, USA, 179-183.

McQuigg, J. (1954) A simple index of drought conditions, Weatherwise, 7(3): 64-67.

Medzini, A. \& Wolf, A.T. (2004) Towards a Middle East at peace: hidden issues in ArabIsraeli hydropolitics, International Journal of Water Resources Development, 20(2): 193-204.

Mekonnen, M.M., Gerbens-Leenes, P.W. \& Hoekstra, A.Y. (2015) The consumptive water footprint of electricity and heat: a global assessment, Environmental Science: Water Research \& Technology, 1(3): 285-297.

Mekonnen, M.M., Gerbens-Leenes, P.W. \& Hoekstra, A.Y. (2016) Future electricity: the challenge of reducing both carbon and water footprint, Science of The Total Environment, 569: 1282-1288.

Mekonnen, M.M. \& Hoekstra, A.Y. (2010a) A global and high-resolution assessment of the green, blue and grey water footprint of wheat, Hydrology and Earth System Sciences, 14(7): 1259-1276.

Mekonnen, M.M. \& Hoekstra, A.Y. (2010b) The green, blue and grey water footprint of crops and derived crop products, Value of Water Research Report Series No. 47, UNESCO-IHE: Delft, the Netherlands, $35 \mathrm{pp}$.

Mekonnen, M.M. \& Hoekstra, A.Y. (2011a) The green, blue and grey water footprint of crops and derived crop products, Hydrology and Earth System Sciences, 15(5): 1577-1600.

Mekonnen, M.M. \& Hoekstra, A.Y. (2011b) National water footprint accounts: the green, blue and grey water footprint of production and consumption, Value of Water Research Report Series No. 50, UNESCO-IHE: Delft, the Netherlands, 44 pp.

Mekonnen, M.M. \& Hoekstra, A.Y. (2012a) The blue water footprint of electricity from hydropower, Hydrology and Earth System Sciences, 16(1): 179-187.

Mekonnen, M.M. \& Hoekstra, A.Y. (2012b) A global assessment of the water footprint of farm animal products, Ecosystems, 15(3): 401-415.

Mekonnen, M.M. \& Hoekstra, A.Y. (2014) Water footprint benchmarks for crop production: a first global assessment, Ecological Indicators, 46: 214-223. 
Mekonnen, M.M. \& Hoekstra, A.Y. (2016) Four billion people facing severe water scarcity, Science Advances, 2(2): e1500323.

Messerschmid, C. \& Selby, J. (2015) Misrepresenting the Jordan river basin, Water Alternatives, 8(2): 258-279.

Meyer, S.J., Hubbard, K.G. \& Wilhite, D.A. (1993) A crop-specific drought index for corn: 1. model development and validation, Agronomy Journal, 85(2): 388-395.

Middleton, N.J. \& Thomas, D.S.G. (1992) World Atlas of Desertification, Arnold: London, UK, 69 pp.

Middleton, N.J. \& Thomas, D.S.G. (1997) World Atlas of Desertification, 2nd ed., Arnold: London, UK 182 pp.

Millennium Ecosystem Assessment (2005) Ecosystems and human well-being: synthesis, World Resources Institute: Washington, D.C., USA, 137 pp.

Miller, G.R., Chen, X., Rubin, Y., Ma, S. \& Baldocchi, D.D. (2010) Groundwater uptake by woody vegetation in a semiarid oak savanna, Water Resources Research, 46: W10503.

Ministry EMWE (2011) Stratégie nationale de l'eau, Department of Water, Ministry of Energy, Mining, Water and Environment: Rabat, Morocco, available at: www.minenv.gov.ma/PDFs/EAU/strategie_eau.pdf (accessed on 21 January 2013).

Ministry EMWE. 2012. Les eaux souterraines, Department of Water, Ministry of Energy, Mining, Water and Environment: Rabat, Morocco, available at: http://www.water.gov.ma/index.cfm?gen=true\&id=12\&ID_PAGE $=42$ (accessed on 8 December 2012).

Ministry of Water and Irrigation (MWI) (2009) Water for life: Jordan's water strategy 2008-2022, Ministry of Water and Irrigation: Amman, Jordan, 70 pp.

Ministry of Water and Irrigation (MWI) (2012) Annual report 2012, Ministry of Water and Irrigation: Amman, Jordan, $77 \mathrm{pp}$.

Ministry of Water and Irrigation (MWI) (2013) Jordan water sector: facts and figures 2013, Ministry of Water and Irrigation: Amman, Jordan, 29 pp.

Mishra, A.K. \& Singh, V.P. (2010) A review of drought concepts, Journal of Hydrology, 391(1-2): 204-216.

Mohsen, M.S. (2007) Water strategies and potential of desalination in Jordan, Desalination, 203(1-3): 27-46.

Molden, D. (2007) Water for Food, Water for Life: A Comprehensive Assessment of Water Management in Agriculture, Earthscan/International Water Management Institute: London, UK; Colombo, Sri Lanka.

Molle, F., Venot, J.-P. \& Hassan, Y. (2008) Irrigation in the Jordan valley: are water pricing policies overly optimistic?, Agricultural Water Management, 95(4): 427438.

Moran, M.S., Clarke, T.R., Inoue, Y. \& Vidal, A. (1994) Estimating crop water-deficit using the relation between surface-air temperature and spectral vegetation index, Remote Sensing of Environment, 49(3): 246-263.

Mourad, K.A., Gaese, H. \& Jabarin, A.S. (2010) Economic value of tree fruit production in Jordan valley from a virtual water perspective, Water Resources Management, 24(10): 2021-2034. 
Mu, Q., Zhao, M., Kimball, J.S., McDowell, N.G. \& Running, S.W. (2013) A remotely sensed global terrestrial drought severity index, Bulletin of the American Meteorological Society, 94(1): 83-98.

Munger, T.T. (1916) Graphic method of representing and comparing drought intensities, Monthly Weather Review, 44(11): 642-643.

Myneni, R.B., Tucker, C.J., Asrar, G. \& Keeling, C.D. (1998) Interannual variations in satellite-sensed vegetation index data from 1981 to 1991, Journal of Geophysical Research-Atmospheres, 103(D6): 6145-6160.

Namrouqa, H. (2012) Yarmouk water sharing violations require political solution, available at: http://www.jordantimes.com/news/local/yarmouk-water-sharingviolations-require-politicalsolution \%E2\%80\%99 (accessed on 2 April 2015).

Namrouqa, H. (2013) King inaugurates Disi water project, available at: http://www.jordantimes.com/news/local/king-inaugurates-disi-water-project (accessed on 7 May 2015).

Narasimhan, B. \& Srinivasan, R. (2005) Development and evaluation of soil moisture deficit index (SMDI) and evapotranspiration deficit index (ETDI) for agricultural drought monitoring, Agricultural and Forest Meteorology, 133(1-4): 69-88.

New, M., Lister, D., Hulme, M. \& Makin, I. (2002) A high-resolution data set of surface climate over global land areas, Climate Research, 21(1): 1-25.

Nortcliff, S., Carr, G., Potter, R.B. \& Darmame, K. (2008) Jordan's water resources: challenges for the future, Geographical Paper No. 185, The University of Reading: Reading, UK, 24 pp.

Nunez, M., Pfister, S., Anton, A., Munoz, P., Hellweg, S., Koehler, A. \& Rieradevall, J. (2013) Assessing the Environmental Impact of Water Consumption by Energy Crops Grown in Spain, Journal of Industrial Ecology, 17(1): 90-102.

Odegard, I.Y.R. \& van der Voet, E. (2014) The future of food - scenarios and the effect on natural resource use in agriculture in 2050, Ecological Economics, 97(0): 51-59.

OECD/IEA (2016) World Energy Outlook 2016, International Energy Agency: Paris, France.

Official State Gazette (1995) Royal decree no. 1-95-154 promulgating law no. 10-95 on water, available at: http://ocid.nacse.org/rewab/docs/Royal_Decree_No_1-95154_Promulgating_Law_on_Water_EN.pdf (accessed on 3 January 2013).

Ohlsson, L. (2000) Water conflicts and social resource scarcity, Physics and Chemistry of the Earth Part B-Hydrology Oceans and Atmosphere, 25(3): 213-220.

Oki, T., Agata, Y., Kanae, S., Saruhashi, T., Yang, D. \& Musiake, K. (2001) Global assessment of current water resources using total runoff integrating pathways, Hydrological Sciences Journal, 46(6): 983-995.

Oki, T. \& Kanae, S. (2006) Global hydrological cycles and world water resources, Science, 313(5790): 1068-1072.

Palmer, W.C. (1965) Meteorological drought, Research paper 45, US Department of Commerce: Washington, D.C., USA, 58 pp.

Palmer, W.C. (1968) Keeping track of crop moisture conditions, nationwide: the new crop moisture index, Weatherwise, 21(4): 156-161.

Peixoto, J.P. \& Oort, A.H. (1992) Physics of Climate, American Institute of Physics: New York, NY, USA. 
Pereira, L.S., Cordery, I. \& Iacovides, I. (2002) Coping with water scarcity, Technical Documents in Hydrology, Report No. 58, UNESCO: Paris, France, 269 pp..

Perez-Mendoza, H.A., Jaime Zuniga-Vega, J., Zurita-Gutierrez, Y.H., Fornoni, J., SolanoZavaleta, I., Hernandez-Rosas, A.L. \& Molina-Moctezuma, A. (2013) Demographic importance of the life-cycle components in sceloporus grammicus, Herpetologica, 69(4): 411-435.

Peters, A.J., Walter-Shea, E.A., Ji, L., Vina, A., Hayes, M. \& Svoboda, M.D. (2002) Drought monitoring with NDVI-based standardized vegetation index, Photogrammetric Engineering and Remote Sensing, 68(1): 71-75.

Pfister, S., Koehler, A. \& Hellweg, S. (2009) Assessing the environmental impacts of freshwater consumption in LCA, Environmental Science \& Technology, 43(11): 4098-4104.

Portmann, F.T., Siebert, S. \& Döll, P. (2010) MIRCA2000 - global monthly irrigated and rainfed crop areas around the year 2000: a new high-resolution data set for agricultural and hydrological modeling, Global Biogeochemical Cycles, 24: GB1011.

Postel, S.L., Daily, G.C. \& Ehrlich, P.R. (1996) Human appropriation of renewable fresh water, Science, 271(5250): 785-788.

Pouzols, F.M., Toivonen, T., Di Minin, E., Kukkala, A.S., Kullberg, P., Kuustera, J., Lehtomaki, J., Tenkanen, H., Verburg, P.H. \& Moilanen, A. (2014) Global protected area expansion is compromised by projected land-use and parochialism, Nature, 516(7531): 383-386.

Ramankutty, N., Evan, A.T., Monfreda, C. \& Foley, J.A. (2008) Farming the planet: 1. geographic distribution of global agricultural lands in the year 2000, Global Biogeochemical Cycles, 22: GB1003.

Ramirez, O.A., Ward, F.A., Al-Tabini, R. \& Phillips, R. (2011) Efficient water conservation in agriculture for growing urban water demands in Jordan, Water Policy, 13(1): 102-124.

Riad, S. (2003) Typologie et analyse hydrologique des eaux superficielles à partir de quelques bassins versants représentatifs du Maroc, unpublished thesis, available at: http://ori-nuxeo.univ-lille1.fr/nuxeo/site/esupversions/e5d351a6ce4c-4b64-b891-84d85f3d8f02 (accessed on 19 June 2013).

Richter, B.D., Davis, M.M., Apse, C. \& Konrad, C. (2012) A presumptive standard for environmental flow protection, River Research and Applications, 28(8): 1312-1321.

Rickard, D.S. (1960) The occurrence of agricultural drought at Ashburton, New Zealand, New Zealand Journal of Agricultural Research, 3(3): 431-441.

Rijsberman, F.R. (2006) Water scarcity: fact or fiction?, Agricultural Water Management, 80(1-3): 5-22.

Robinson, T.P., Thornton, P.K., Franceschini, G., Kruska, R., Chiozza, F., Notenbaert, A.M.O., Cecchi, G., Herrero, M., Epprecht, M. \& Fritz, S. (2011) Global Livestock Production Systems, FAO/ILRI: Rome, Italy.

Robinson, T.P., Wint, G.R.W., Conchedda, G., Van Boeckel, T.P., Ercoli, V., Palamara, E., Cinardi, G., D'Aietti, L., Hay, S.I. \& Gilbert, M. (2014) Mapping the global distribution of livestock, PLOS ONE, 9(5): e96084. 
Rockström, J. (1999) On-farm green water estimates as a tool for increased food production in water scarce regions, Physics and Chemistry of the Earth Part BHydrology Oceans and Atmosphere, 24(4): 375-383.

Rockström, J. (2001) Green water security for the food makers of tomorrow: windows of opportunity in drought-prone savannahs, Water Science and Technology, 43(4): 71-78.

Rockström, J. \& Falkenmark, M. (2000) Semiarid crop production from a hydrological perspective: gap between potential and actual yields, Critical Reviews in Plant Sciences, 19(4): 319-346.

Rockström, J., Falkenmark, M., Karlberg, L., Hoff, H., Rost, S. \& Gerten, D. (2009) Future water availability for global food production: The potential of green water for increasing resilience to global change, Water Resources Research, 45: W00A12.

Rockström, J. \& Gordon, L. (2001) Assessment of green water flows to sustain major biomes of the world: Implications for future ecohydrological landscape management, Physics and Chemistry of the Earth, Part B: Hydrology, Oceans and Atmosphere, 26(11): 843-851.

Rockström, J., Gordon, L., Folke, C., Falkenmark, M. \& Engwall, M. (1999) Linkages among water vapor flows, food production, and terrestrial ecosystem services, Conservation Ecology, 3(2): 5.

Rockstrom, J., Lannerstad, M. \& Falkenmark, M. (2007) Assessing the water challenge of a new green revolution in developing countries, Proceedings of the National Academy of Sciences, 104(15): 6253-6260.

Rockstrom, J., Steffen, W., Noone, K., Persson, A., Chapin, F.S., Lambin, E.F., Lenton, T.M., Scheffer, M., Folke, C., Schellnhuber, H.J., Nykvist, B., de Wit, C.A., Hughes, T., van der Leeuw, S., Rodhe, H., Sorlin, S., Snyder, P.K., Costanza, R., Svedin, U., Falkenmark, M., Karlberg, L., Corell, R.W., Fabry, V.J., Hansen, J., Walker, B., Liverman, D., Richardson, K., Crutzen, P. \& Foley, J.A. (2009) A safe operating space for humanity, Nature, 461(7263): 472-475.

Rockström, J., Williams, J., Daily, G., Noble, A., Matthews, N., Gordon, L., Wetterstrand, H., DeClerck, F., Shah, M., Steduto, P., de Fraiture, C., Hatibu, N., Unver, O., Bird, J., Sibanda, L. \& Smith, J. (2017) Sustainable intensification of agriculture for human prosperity and global sustainability, Ambio, 46(1): 4-17.

Rodrigues, A.S.L., Akcakaya, H.R., Andelman, S.J., Bakarr, M.I., Boitani, L., Brooks, T.M., Chanson, J.S., Fishpool, L.D.C., Da Fonseca, G.A.B., Gaston, K.J., Hoffmann, M., Marquet, P.A., Pilgrim, J.D., Pressey, R.L., Schipper, J., Sechrest, W., Stuart, S.N., Underhill, L.G., Waller, R.W., Watts, M.E.J. \& Yan, X. (2004a) Global gap analysis: priority regions for expanding the global protected-area network, Bioscience, 54(12): 1092-1100.

Rodrigues, A.S.L., Andelman, S.J., Bakarr, M.I., Boitani, L., Brooks, T.M., Cowling, R.M., Fishpool, L.D.C., da Fonseca, G.A.B., Gaston, K.J., Hoffmann, M., Long, J.S., Marquet, P.A., Pilgrim, J.D., Pressey, R.L., Schipper, J., Sechrest, W., Stuart, S.N., Underhill, L.G., Waller, R.W., Watts, M.E.J. \& Yan, X. (2004b) Effectiveness of the global protected area network in representing species diversity, Nature, 428(6983): 640-643.

Rolinski, S., Müller, C., Heinke, J., Weindl, I., Biewald, A., Bodirsky, B.L., Bondeau, A., Boons-Prins, E.R., Bouwman, A.F., Leffelaar, P.A., te Roller, J.A., Schaphoff, S. 
\& Thonicke, K. (2017) Modeling vegetation and carbon dynamics of managed grasslands at the global scale with LPJmL 3.6, in review, Geoscientific Model Development Discussions, https://doi.org/10.5194/gmd-2017-26.

Rost, S., Gerten, D., Bondeau, A., Lucht, W., Rohwer, J. \& Schaphoff, S. (2008) Agricultural green and blue water consumption and its influence on the global water system, Water Resources Research, 44: W09405.

Salameh, E., Alraggad, M. \& Tarawneh, A. (2014) Disi water use for irrigation - a false decision and its consequences, CLEAN - Soil, Air, Water, 42(12): 1681-1686.

Saleska, S.R., Didan, K., Huete, A.R. \& da Rocha, H.R. (2007) Amazon forests green-up during 2005 drought, Science, 318(5850): 612-612.

Sandholt, I., Rasmussen, K. \& Andersen, J. (2002) A simple interpretation of the surface temperature/vegetation index space for assessment of surface moisture status, Remote Sensing of Environment, 79(2-3): 213-224.

Savenije, H.H.G. (2000) Water scarcity indicators; the deception of the numbers, Physics and Chemistry of the Earth Part B-Hydrology Oceans and Atmosphere, 25(3): 199-204.

Savenije, H.H.G. (2004) The importance of interception and why we should delete the term evapotranspiration from our vocabulary, Hydrological Processes, 18(8): 1507-1511.

Savenije, H.H.G., Hoekstra, A.Y. \& van der Zaag, P. (2014) Evolving water science in the Anthropocene, Hydrology and Earth System Sciences, 18(1): 319-332.

Schenker, D. 2014. Twenty years of Israeli-Jordanian peace: a brief assessment, The Washington Institute for Near East Policy: Washington, D.C., USA, available at: http://www.washingtoninstitute.org/policy-analysis/view/twenty-years-ofisraeli-jordanian-peace-a-brief-assessment (accessed on 2 April 2015).

Schneider, A., Friedl, M.A. \& Potere, D. (2010) Mapping global urban areas using MODIS 500-m data: New methods and datasets based on 'urban ecoregions', Remote Sensing of Environment, 114(8): 1733-1746.

Schuol, J., Abbaspour, K.C., Yang, H., Srinivasan, R. \& Zehnder, A.J.B. (2008) Modeling blue and green water availability in Africa, Water Resources Research, 44: W07406.

Schyns, J.F., Booij, M.J. \& Hoekstra, A.Y. (2017) The water footprint of wood for lumber, pulp, paper, fuel and firewood, Advances in Water Resources, 107: 490-501.

Schyns, J.F. \& Hoekstra, A.Y. (2014) The added value of water footprint assessment for national water policy: a case study for Morocco, PLoS ONE, 9(6): e99705.

Schyns, J.F., Hoekstra, A.Y. \& Booij, M.J. (2015) Review and classification of indicators of green water availability and scarcity, Hydrology and Earth System Sciences, 19(11): 4581-4608.

Scott, C.A., El-Naser, H., Hagan, R.E. \& Hijazi, A. (2003) Facing water scarcity in Jordan - reuse, demand reduction, energy, and transboundary approaches to assure future water supplies, Water International, 28(2): 209-216.

Seckler, D., Barker, R. \& Amarasinghe, U. (1999) Water scarcity in the twenty-first century, International Journal of Water Resources Development, 15(1-2): 29-42.

Shafer, B.A. \& Dezman, L.E. (1982) Development of a surface water supply index (SWSI) to assess the severity of drought conditions in snowpack runoff areas. In: Proceedings of the 50th annual western snow conference, Reno, Nevada, USA, 19-23 April 1982, 164-175. 
Shatanawi, M., Fardous, A., Mazahrih, N. \& Duqqah, M. (2005) Irrigation system performance in Jordan, Options Méditerranéennes, Serie B, 52: 123-132.

Siebert, S. \& Döll, P. (2010) Quantifying blue and green virtual water contents in global crop production as well as potential production losses without irrigation, Journal of Hydrology, 384(3-4): 198-217.

Simpson, W.T. (1998) Equilibrium moisture content of wood in outdoor locations in the United States and worldwide, Research Note FPL-RN-0268, USDA: Washington, D.C., USA, available at: http://www.woodweb.com/knowledge_base_images/zp/equilibrium_moisture_ content.pdf (accessed on 15 August 2016).

Sivakumar, M.V.K. (2010) Agricultural drought - WMO perspectives. In: Sivakumar, M.V.K., Motha, R.P., Wilhite, D.A. \& Wood, D.A. (eds.) Proceedings of the WMO/UNISDR expert group meeting on agricultural drought indices, Murcia, Spain, 2-4 June 2010, 22-34.

Sivakumar, M.V.K., Motha, R.P., Wilhite, D.A. \& Wood, D.A. (2011) Agricultural drought indices, Proceedings of the WMO/UNISDR expert group meeting on agricultural drought indices, 2-4 June 2010, Murcia, Spain, AGM-11, WMO/TD No. 1572; WAOB-2011, World Meteorological Organization: Geneva, Switzerland, $197 \mathrm{pp}$.

Sly, W.K. (1970) A Climatic Moisture Index for Land and Soil Classification in Canada, Canadian Journal of Soil Science, 50(3): 291-301.

Smakhtin, V., Revenga, C. \& Döll, P. (2004) A pilot global assessment of environmental water requirements and scarcity, Water International, 29(3): 307-317.

Smakhtin, V.U. (2001) Low flow hydrology: a review, Journal of Hydrology, 240(3-4): 147186.

Smith, W.K., Zhao, M. \& Running, S.W. (2012) Global bioenergy capacity as constrained by observed biospheric productivity rates, Bioscience, 62(10): 911-922.

Sophocleous, M. (2000) From safe yield to sustainable development of water resources the Kansas experience, Journal of Hydrology, 235(1-2): 27-43.

Sowers, J., Vengosh, A. \& Weinthal, E. (2011) Climate change, water resources, and the politics of adaptation in the Middle East and North Africa, Climatic Change, 104(3-4): 599-627.

Speight, J.G. (ed.) (2010) The Biofuels Handbook, Royal Society of Chemistry Publishing: Cambridge, UK.

Sperna Weiland, F.C., van Beek, L.P.H., Kwadijk, J.C.J. \& Bierkens, M.F.P. (2010) The ability of a GCM-forced hydrological model to reproduce global discharge variability, Hydrology and Earth System Sciences, 14(8): 1595-1621.

Stadler, S.J. (2005) Aridity indexes. In: Oliver, J.E. (ed.) Encyclopedia of World Climatology, Springer: Heidelberg, Germany, 89-94.

Steduto, P., Hsiao, T.C., Raes, D. \& Fereres, E. (2009) Aquacrop-the FAO Crop model to simulate yield response to water: i. concepts and underlying principles, Agronomy Journal, 101(3): 426-437.

Steffen, W., Richardson, K., Rockström, J., Cornell, S.E., Fetzer, I., Bennett, E.M., Biggs, R., Carpenter, S.R., de Vries, W., de Wit, C.A., Folke, C., Gerten, D., Heinke, J., Mace, G.M., Persson, L.M., Ramanathan, V., Reyers, B. \& Sörlin, S. (2015) 
Planetary boundaries: guiding human development on a changing planet, Science, 347(62230): 1259855.

Stöckle, C.O., Donatelli, M. \& Nelson, R. (2003) Cropsyst, a cropping systems simulation model, European Journal of Agronomy, 18(3-4): 289-307.

Sullivan, C.A., Meigh, J.R. \& Giacomello, A.M. (2003) The water poverty index: development and application at the community scale, Natural Resources Forum, 27(3): 189-199.

Svoboda, M., LeComte, D., Hayes, M., Heim, R., Gleason, K., Angel, J., Rippey, B., Tinker, R., Palecki, M., Stooksbury, D., Miskus, D. \& Stephens, S. (2002) The drought monitor, Bulletin of the American Meteorological Society, 83(8): 1181-1190.

Sweet, J. (1998) Livestock-coping with drought: Namibia-a case study, Overseas Development Institute: London, UK, 32 pp.

Talozi, S., Al Sakaji, Y. \& Altz-Stamm, A. (2015) Towards a water-energy-food nexus policy: realizing the blue and green virtual water of agriculture in Jordan, International Journal of Water Resources Development, 31(3): 461-482.

Tate, E.L. \& Gustard, A. (2000) Drought definition: a hydrological perspective. In: Vogt, J. \& Somma, F. (2000) Drought and Drought Mitigation in Europe, Advances in Natural and Technological Hazards Research, Springer: Dordrecht, the Netherlands, 23-48.

Tekken, V. \& Kropp, J. (2012) Climate-driven or human-induced: indicating severe water scarcity in the Moulouya river basin (Morocco), Water, 4(4): 959.

Thornthwaite, C.W. (1931) The climates of North America: according to a new classification, Geographical Review, 21(4): 633-655.

Thornthwaite, C.W. (1948) An approach toward a rational classification of climate, The Geographical Review, 38: 55-94.

Tian, M.H. \& Ke, S.F. (2012) Virtual water content and trade analysis of primary woody products in China, International Forestry Review, 14(3): 380-390.

Toernros, T. \& Menzel, L. (2014) Addressing drought conditions under current and future climates in the Jordan river region, Hydrology and Earth System Sciences, 18(1): 305-318.

Transeau, E.N. (1905) Forest centers of Eastern America, The American Naturalist, 39(468): 875-889.

Trombetta, L. (2014) The EU and the Syrian crisis as viewed from the Middle East, The International Spectator, 49(3): 27-39.

Tsakiris, G., Pangalou, D. \& Vangelis, H. (2007) Regional drought assessment based on the reconnaissance drought index (RDI), Water Resources Management, 21(5): 821-833.

Tsakiris, G. \& Vangelis, H. (2005) Establishing a drought index incorporating evapotranspiration, European Water, 9(10): 3-11.

Tucker, C.J. (1979) Red and photographic infrared linear combinations for monitoring vegetation, Remote Sensing of Environment, 8(2): 127-150.

U.S. Energy Information Administration (EIA) (2014) Jordan: international energy data and analysis, available at: www.eia.gov/beta/international/country.cfm?iso=JOR (accessed on 7 May 2015). 
Ugalde, L. \& Pérez, O. (2001) Mean annual volume increment of selected industrial forest plantation species. In: Mead, D.J. (ed.) Forest Plantations Thematic Papers, Working Paper FP/1. FAO: Rome, Italy, 24 pp.

UNECE/FAO (2010) Forest product conversion factors for the UNECE region, Geneva Timber and Forest Discussion Paper 49, UNECE/FAO: Geneva, Switzerland.

UNECE/FAO (2015) Timber database: export and import unit prices (1964-2014), available at: http://www.unece.org/fileadmin/DAM/timber/statsdata/unit-price1964-2014.xlsx (accessed on 10 October 2016).

UNESCO (1963) Bioclimatic map of the Mediterranean zone: ecological study of the Mediterranean zone, explanatory notes, Arid Zone Research, 21, UNESCOFAO: Paris, France, 58 pp.

United Nations High Commissioner for Refugees (UNHCR) (2014) Syrian refugees in Europe: what Europe can do to ensure protection and solidarity, UNHCR: Geneva, Switzerland, 37 pp..

United Nations High Commissioner for Refugees (UNHCR) (2015) UNHCR Statistical Online Population Database, UNHCR, available at: www.unhcr.org/statistics/populationdatabase (accessed on 20 July 2015).

Urumović, K. \& Urumović Sr, K. (2016) The referential grain size and effective porosity in the Kozeny-Carman model, Hydrology and Earth System Sciences, 20(5): 16691680.

Van Aken, M., Molle, F. \& Venot, J.-P. (2009) Squeezed dry: the historical trajectory of the lower Jordan river basin. In: Molle, F. \& Wester, P. (eds.) River Basin Trajectories: Societies, Environments and Development, CABI \& International Water Management Institute: Wallingford, UK; Colombo, Sri Lanka, 20-46.

Van Dam, J.C., Groenendijk, P., Hendriks, R.F.A. \& Kroes, J.G. (2008) Advances of modeling water flow in variably saturated soils with SWAP, Vadose Zone Journal, 7(2): 640-653.

Van der Ent, R.J., Savenije, H.H.G., Schaefli, B. \& Steele-Dunne, S.C. (2010) Origin and fate of atmospheric moisture over continents, Water Resources Research, 46(9): W09525.

Van Oel, P.R. \& Hoekstra, A.Y. (2012) Towards quantification of the water footprint of paper: a first estimate of its consumptive component, Water Resources Management, 26(3): 733-749.

Van Velthuizen, H., Huddleston, B., Fischer, G., Salvatore, M., Ataman, E., Nachtergaele, F., Zanetti, M., Bloise, M., Antonicelli, A., Bel, J. \& De Liddo, A. (2007) Mapping biophysical factors that influence agricultural production and rural vulnerability, Environment and natural resources series 11, FAO/IIASA: Rome, Italy.

Vanham, D. (2016) Does the water footprint concept provide relevant information to address the water-food-energy-ecosystem nexus?, Ecosystem Services, 17: 298307.

Vanham, D., Hoekstra, A.Y., Wada, Y., Bouraoui, F., de Roo, A., Mekonnen, M.M., van de Bund, W.J., Batelaan, O., Pavelic, P., Bastiaanssen, W.G.M., Kummu, M., Rockström, J., Liu, J., Bisselink, B., Ronco, P., Pistocchi, A. \& Bidoglio, G. (2018) Physical water scarcity metrics for monitoring progress towards SDG target 6.4: 
an evaluation of indicator 6.4.2 "Level of water stress", Science of The Total Environment, 613-614: 218-232.

Vengosh, A., Hirschfeld, D., Vinson, D., Dwyer, G., Raanan, H., Rimawi, O., Al-Zoubi, A., Akkawi, E., Marie, A., Haquin, G., Zaarur, S. \& Ganor, J. (2009) High naturally occurring radioactivity in fossil groundwater from the Middle East, Environmental Science \& Technology, 43(6): 1769-1775.

Venot, J.-P. \& Molle, F. (2008) Groundwater depletion in the Jordan highlands: can pricing policies regulate irrigation water use?, Water Resources Management, 22(12): 1925-1941.

Venter, O., Fuller, R.A., Segan, D.B., Carwardine, J., Brooks, T., Butchart, S.H.M., Di Marco, M., Iwamura, T., Joseph, L., O'Grady, D., Possingham, H.P., Rondinini, C., Smith, R.J., Venter, M. \& Watson, J.E.M. (2014) Targeting global protected area expansion for imperiled biodiversity, PLoS Biology, 12(6): e1001891.

Verdin, J. \& Klaver, R. (2002) Grid-cell-based crop water accounting for the famine early warning system, Hydrological Processes, 16(8): 1617-1630.

Vicente-Serrano, S.M., Beguería, S. \& López-Moreno, J.I. (2009) A multiscalar drought index sensitive to global warming: the standardized precipitation evapotranspiration index, Journal of Climate, 23(7): 1696-1718.

Vörösmarty, C.J., Douglas, E.M., Green, P.A. \& Revenga, C. (2005) Geospatial indicators of emerging water stress: an application to Africa, Ambio, 34(3): 230-236.

Vörösmarty, C.J., Green, P., Salisbury, J. \& Lammers, R.B. (2000) Global water resources: vulnerability from climate change and population growth, Science, 289(5477): 284-288.

Vörösmarty, C.J., McIntyre, P.B., Gessner, M.O., Dudgeon, D., Prusevich, A., Green, P., Glidden, S., Bunn, S.E., Sullivan, C.A., Liermann, C.R. \& Davies, P.M. (2010) Global threats to human water security and river biodiversity, Nature, 467(7315): 555-561.

Wada, Y. (2013) Human and climate impacts on global water resources, PhD thesis, Department of Physical Geography, Utrecht University: Utrecht, the Netherlands, 470 pp.

Wada, Y., van Beek, L.P.H., Viviroli, D., Duerr, H.H., Weingartner, R. \& Bierkens, M.F.P. (2011) Global monthly water stress: 2. water demand and severity of water stress, Water Resources Research, 47: W07518.

Wada, Y., Wisser, D. \& Bierkens, M.F.P. (2014) Global modeling of withdrawal, allocation and consumptive use of surface water and groundwater resources, Earth Systems Dynamics, 5(1): 15-40.

Wallén, C.C. (1967) Aridity definitions and their applicability, Geografiska Annaler. Series A, Physical Geography, 49(2/4): 367-384.

Walton, K. (1969) The Arid Zones, Transaction Publishers: New Jersey, USA.

Wanders, N., van Lanen, H.A.J. \& van Loon, A.F. (2010) Indicators for drought characterization on a global scale, WATCH Technical Report No. 24, Wageningen University: Wageningen, the Netherlands, 54 pp.

Weiskel, P.K., Wolock, D.M., Zarriello, P.J., Vogel, R.M., Levin, S.B. \& Lent, R.M. (2014) Hydroclimatic regimes: a distributed water-balance framework for hydrologic assessment, classification, and management, Hydrology and Earth System Sciences, 18(10): 3855-3872. 
Wilhelmi, O.V., Hubbard, K.G. \& Wilhite, D.A. (2002) Spatial representation of agroclimatology in a study of agricultural drought, International Journal of Climatology, 22(11): 1399-1414.

Wilhelmi, O.V. \& Wilhite, D.A. (2002) Assessing vulnerability to agricultural drought: a Nebraska case study, Natural Hazards, 25(1): 37-58.

Wilhite, D.A. \& Glantz, M.H. (1985) Understanding the drought phenomenon: the role of definitions, Water International, 10(3): 111-120.

Wint, G.R.W. \& Robinson, T.P. (2007) Gridded Livestock of the World, FAO: Rome, Italy.

Woli, P., Jones, J.W., Ingram, K.T. \& Fraisse, C.W. (2012) Agricultural reference index for drought (ARID), Agronomy Journal, 104(2): 287-300.

World Bank (1997) The Hashemite Kingdom of Jordan: water sector review, volume 1, Report No. 17095-JO, The World Bank Group: Washington, D.C., USA, 34 pp.

World Bank (2015) World development indicators: Jordan, The World Bank Group: Washington, D.C., USA, available at: http://databank.worldbank.org/data/table/source/2?country=JOR\&series=\&peri od (accessed on 20 July 2015).

World Meteorological Organization (1975) Drought and agriculture, Report of the CAgM Working Group on the assessment of drought, Technical Note No. 138, WMO: Geneva, Switzerland.

Wu, H., Hubbard, K.G. \& Wilhite, D.A. (2004) An agricultural drought risk-assessment model for corn and soybeans, International Journal of Climatology, 24(6): 723-741.

WWAP (2014) The United Nations world water development report 2014: water and energy. UNESCO: Paris, France, 133 pp.

WWAP (2015) The United Nations world water development report 2015: water for a sustainable world. UNESCO: Paris, France, 122 pp.

Yao, Y., Liang, S., Qin, Q. \& Wang, K. (2010) Monitoring drought over the conterminous United States using MODIS and NCEP reanalysis-2 data, Journal of Applied Meteorology and Climatology, 49(8): 1665-1680.

Zabel, F., Putzenlechner, B. \& Mauser, W. (2014) Global agricultural land resources - a high resolution suitability evaluation and its perspectives until 2100 under climate change conditions, PLoS ONE, 9(9): e107522.

Zanne, A.E., Lopez-Gonzalez, G., Coomes, D.A., Ilic, J., Jansen, S., Lewis, S.L., Miller, R.B., Swenson, N.G., Wiemann, M.C. \& Chave, J. (2009) Data from: towards a worldwide wood economics spectrum, Dryad Data Repository, doi:10.5061/dryad.234.

Zeitoun, M., Allan, T., Al Aulaqi, N., Jabarin, A. \& Laamrani, H. (2012) Water demand management in Yemen and Jordan: addressing power and interests, The Geographical Journal, 178(1): 54-66.

Zhang, L., Dawes, W. \& Walker, G. (1999) Predicting the effect of vegetation changes on catchment average water balance, Technical Report 99/12, CSIRO Land and Water, $30 \mathrm{pp}$.

Zhang, L., Dawes, W.R. \& Walker, G.R. (2001) Response of mean annual evapotranspiration to vegetation changes at catchment scale, Water Resources Research, 37(3): 701-708. 


\section{Appendix A:}

\section{An Appendix to Chapter 2}

\section{A.1. Derivation of K-Factor in Water Footprint of the Irrigation Supply Network}

The following definitions apply (see Figure A-1):

$A$

$B$

$e_{a}$

$e_{c}$

$f_{\mathrm{E}}$

$K$

$W F_{\text {crop, surf }} \quad=$ surface water footprint of crop production at field level, i.e. the part of the irrigation water that originates from surface water and is lost at the crop field through soil evaporation and crop transpiration.

$W F_{\text {irr.sppl.netw }} \quad=$ water footprint of irrigation supply network, i.e. evaporative losses from network 


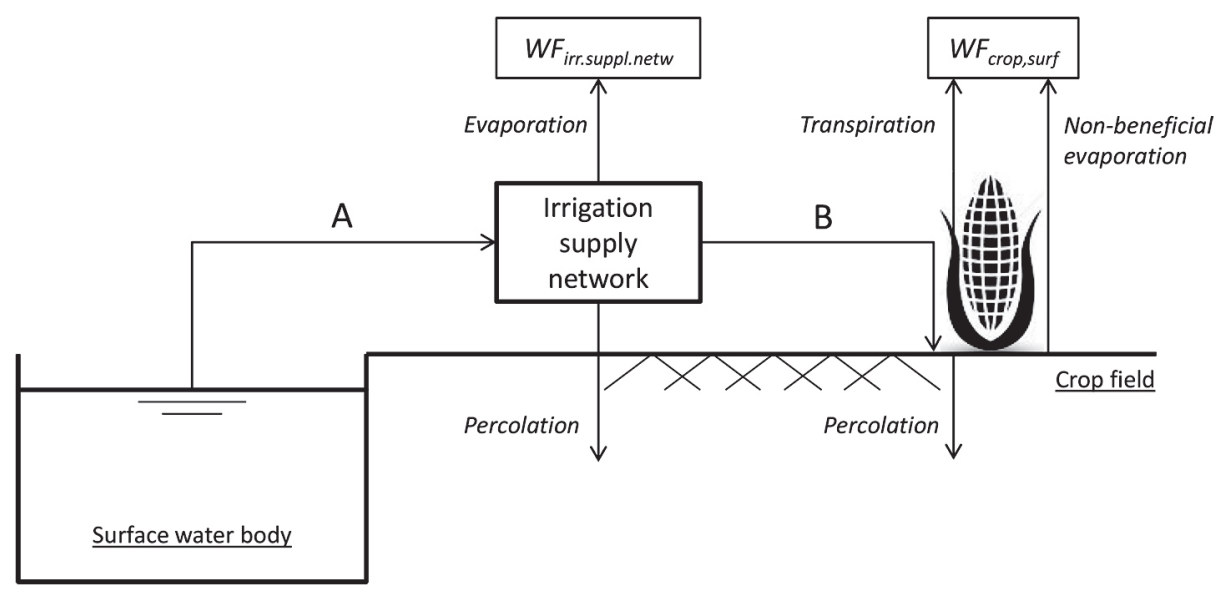

Figure A-1. Schematic representation of the variables involved in estimating the water footprint of the irrigation supply network.

We can then derive the following:

$e_{a}=\frac{W F_{\text {crop }, \text { surf }}}{B} \rightarrow B=\frac{W F_{\text {crop }, \text { surf }}}{e_{a}}$

$e_{c}=\frac{B}{A} \rightarrow A=\frac{B}{e_{c}}=\frac{W F_{\text {crop }, \text { surf }}}{e_{a} \times e_{c}}$

$W F_{\text {irr.sppl.netw }}=K \times W F_{\text {crop, surf }}$

with $K=\left[\frac{1}{e_{\mathrm{a}} \times e_{\mathrm{c}}}-\frac{1}{e_{\mathrm{a}}}\right] \times f_{\mathrm{E}}$ 


\section{Appendix B:}

\section{An Appendix to Chapter 4}

\section{B.1. Absolute Green Water Availability Indicators}

Absolute green water availability indicators are included in Tables B-1 to B-4. Often used symbols in this appendix: Eact is actual evaporation, $E_{\text {pot }}$ is potential evaporation, $E_{\text {pot,c }}$ is crop-specific potential evaporation, $E_{\mathrm{pot}, \text { ref }}$ is potential evaporation of FAO reference crop, $P$ is precipitation, $S$ is soil moisture, $T$ is air temperature, $T r$ act is actual transpiration, $\operatorname{Tr}_{\text {pot }}$ is potential transpiration.

Table B-1. Aridity indicators.

\begin{tabular}{|c|c|c|c|}
\hline Name & Abbreviation & Formula/description & Reference \\
\hline $\begin{array}{l}\text { Rainfall- } \\
\text { evaporation } \\
\text { ratio }\end{array}$ & RER & $\begin{array}{l}\frac{P}{E_{\text {ow }}} \\
\text { Eow is open-water evaporation. }\end{array}$ & $\begin{array}{l}\text { Transeau } \\
(1905)\end{array}$ \\
\hline Rain factor & RF & $\frac{P}{T}$ & Lang (1920) \\
\hline $\begin{array}{l}\text { Koloskov } \\
\text { index }\end{array}$ & KI & $\begin{array}{l}\frac{P}{\sum T} \\
\text { Sum over vegetative period. }\end{array}$ & $\begin{array}{l}\text { Koloskov } \\
(1925) \text { as cited } \\
\text { by World } \\
\text { Meteorologic } \\
\text { al } \\
\text { Organization } \\
(1975)\end{array}$ \\
\hline $\begin{array}{l}\text { de Martonne's } \\
\text { aridity index }\end{array}$ & dM-AI & $\frac{P}{T+10}$ & $\begin{array}{l}\text { de Martonne } \\
\text { (1926) as cited } \\
\text { by } \\
\text { Thornthwaite } \\
(1931) \text {, } \\
\text { Budyko } \\
\text { (1958) and de } \\
\text { Martonne } \\
\text { (1942) }\end{array}$ \\
\hline
\end{tabular}


Table B-1 (continued). Aridity indicators.

\begin{tabular}{|c|c|c|c|}
\hline Name & Abbreviation & Formula/description & Reference \\
\hline $\begin{array}{l}\text { Precipitation- } \\
\text { saturation } \\
\text { deficit ratio }\end{array}$ & PDR & $\begin{array}{l}\frac{P}{D} \\
D \text { is mean annual atmospheric } \\
\text { saturation deficit }\end{array}$ & $\begin{array}{l}\text { Meyer (1926) } \\
\text { as cited by } \\
\text { Thornthwaite } \\
\text { (1931) and } \\
\text { Budyko } \\
\text { (1958) }\end{array}$ \\
\hline $\begin{array}{l}\text { Reichel's } \\
\text { aridity index }\end{array}$ & R-AI & $\begin{array}{l}\frac{N \times P}{T+10} \\
N \text { is number of rainy days. }\end{array}$ & $\begin{array}{l}\text { Reichel (1928) } \\
\text { as cited by } \\
\text { Perez- } \\
\text { Mendoza et } \\
\text { al. (2013) }\end{array}$ \\
\hline $\begin{array}{l}\text { Marcovitch's } \\
\text { index }\end{array}$ & MI & $\begin{array}{l}0.5 L^{2} \times\left(\frac{100}{P}\right)^{2} \\
L \text { is the total number of } 2 \text { or more } \\
\text { consecutive days above } 90^{\circ} \mathrm{F} \text { for } \\
\text { the months of June, July, August, } \\
\text { and September; Total } P \text { for those } \\
\text { months. }\end{array}$ & $\begin{array}{l}\text { Marcovitch } \\
\text { (1930) }\end{array}$ \\
\hline $\begin{array}{l}\text { Shostakovich } \\
\text { index }\end{array}$ & SI & $\begin{array}{l}\frac{P}{T} \\
P \text { during vegetative period and } \\
\text { mean } T \text { over this period. }\end{array}$ & $\begin{array}{l}\text { Shostakovich } \\
\text { (1932) as cited } \\
\text { by Jenny } \\
\text { (1941) }\end{array}$ \\
\hline $\begin{array}{l}\text { Emberger's } \\
\text { aridity index }\end{array}$ & E-AI & $\begin{array}{l}\frac{100 P}{(M+m)(M-m)} \\
M \text { is mean temperature of the } \\
\text { warmest month and } m \text { is mean } \\
\text { temperature of the coldest month }\end{array}$ & $\begin{array}{l}\text { Emberger } \\
(1932) \text { as cited } \\
\text { by Wallén } \\
(1967)\end{array}$ \\
\hline
\end{tabular}


Table B-1 (continued). Aridity indicators.

\begin{tabular}{|c|c|c|c|}
\hline Name & Abbreviation & Formula/description & Reference \\
\hline $\begin{array}{l}\text { Precipitation } \\
\text { effectiveness } \\
\text { index }\end{array}$ & PE & $\sum_{n=1}^{12} 10 \frac{P_{\mathrm{n}}}{E_{\text {pot }_{\mathrm{n}}}}$ & $\begin{array}{l}\text { Thornthwaite } \\
\text { (1931) }\end{array}$ \\
\hline $\begin{array}{l}\text { Hydrothermal } \\
\text { coefficient }\end{array}$ & 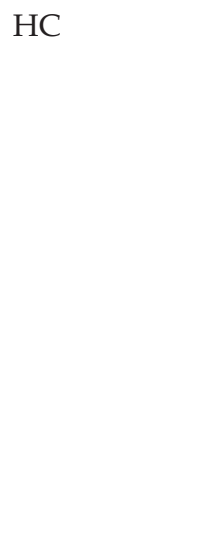 & $\frac{P}{\left.\sum T\right|_{T>10^{\circ} C}}$ & $\begin{array}{l}\text { Selianinov } \\
(1930 ; 1937) \\
\text { as cited by } \\
\text { Budyko } \\
(1958) \text { and } \\
\text { World } \\
\text { Meteorologic } \\
\text { al } \\
\text { Organization } \\
\text { (1975) }\end{array}$ \\
\hline $\begin{array}{l}\text { Köppen } \\
\text { classification }\end{array}$ & $\mathrm{KC}$ & $\begin{array}{l}\text { Threshold for classifying area as } \\
\text { semi-arid: } \\
P=2(T+14) \text { (summer } \\
\text { rainfall) } \\
P=2 T \text { (winter rainfall) } \\
\text { Threshold for classifying area as } \\
\text { arid: } \\
P=T+14 \text { (summer rainfall) } \\
P=T \text { (winter rainfall) } \\
P \text { is annual precipitation amount } \\
\text { in cm/y and } T \text { is mean annual } \\
\text { temperature in }{ }^{\circ} \mathrm{C} \text {. }\end{array}$ & $\begin{array}{l}\text { Köppen } \\
\text { (1931) }\end{array}$ \\
\hline
\end{tabular}


Table B-1 (continued). Aridity indicators.

\begin{tabular}{|c|c|c|c|}
\hline Name & Abbreviation & Formula/description & Reference \\
\hline $\begin{array}{l}\text { Aridity } \\
\text { coefficient }\end{array}$ & $\mathrm{AC}$ & $\begin{array}{l}f_{\text {lat }} \times\left(T_{\max }-T_{\min }\right) \times\left(\frac{P_{\max }-P_{\min }}{P_{\text {avg }}}\right) \\
\text { flat is latitude factor, } T_{\max } \text { is } \\
\text { temperature of the long-term } \\
\text { mean warmest month, } T_{\min } \text { is } \\
\text { temperature of the long-term } \\
\text { mean coldest month, } P_{\max } \text { is largest } \\
\text { annual precipitation amount on } \\
\text { record, } P_{\text {min }} \text { is smallest annual } \\
\text { precipitation amount on record } \\
\text { and } P_{\text {avg }} \text { is average annual } \\
\text { precipitation amount on record. }\end{array}$ & $\begin{array}{l}\text { Gorczynski } \\
\text { (1940) }\end{array}$ \\
\hline $\begin{array}{l}\text { Modified de } \\
\text { Martonne } \\
\text { aridity index }\end{array}$ & MdM-AI & $\begin{array}{l}\frac{1}{2}\left(\frac{P}{T+10}+\frac{12 P_{\mathrm{d}}}{T_{\mathrm{d}}+10}\right) \\
P_{\mathrm{d}} \text { is precipitation in the driest } \\
\text { month and } T_{\mathrm{d}} \text { is temperature in } \\
\text { the driest month. }\end{array}$ & $\begin{array}{l}\text { de Martonne } \\
\text { (1942) }\end{array}$ \\
\hline $\begin{array}{l}\text { Popov's } \\
\text { aridity index }\end{array}$ & P-AI & $\begin{array}{l}\frac{P_{\text {eff }}}{2.4\left(t-t^{\prime}\right) r} \\
P_{\text {eff }} \text { is annual amount of } \\
\text { precipitation available to plants, } r \\
\text { is factor depending on day length } \\
\text { and } t-t^{\prime} \text { is annual mean wet bulb } \\
\text { depression in }{ }^{\circ} \mathrm{C} \text {. }\end{array}$ & $\begin{array}{l}\text { Popov (1948) } \\
\text { as cited by } \\
\text { World } \\
\text { Meteorologic } \\
\text { al } \\
\text { Organization } \\
\text { (1975) }\end{array}$ \\
\hline
\end{tabular}


Table B-1 (continued). Aridity indicators.

\begin{tabular}{|c|c|c|c|}
\hline Name & Abbreviation & Formula/description & Reference \\
\hline $\begin{array}{l}\text { Moisture } \\
\text { index, aridity } \\
\text { index, } \\
\text { humidity } \\
\text { index }\end{array}$ & & $\begin{array}{l}I_{\mathrm{a}}=\frac{100 d}{E_{\mathrm{pot}}} \\
I_{\mathrm{h}}=\frac{100 \mathrm{~s}}{E_{\mathrm{pot}}} \\
I_{\mathrm{m}}=I_{\mathrm{m}}-0.6 I_{\mathrm{a}} \\
\text { where } d \text { is a water deficiency when } \\
P<E_{\mathrm{pot}} \text { and } s \text { is a water surplus } \\
\text { when } P>E_{\mathrm{pot}} \\
I_{\mathrm{m}} \text { is an overall measure of the } \\
\text { moisture conditions of a region, } \\
\text { giving more weight to } \mathrm{I}_{\mathrm{h}} \text { since } s \text { in } \\
\text { one season can partially } \\
\text { compensate for } d \text { in another } \\
\text { season. }\end{array}$ & $\begin{array}{l}\text { Thornthwaite } \\
\text { (1948) }\end{array}$ \\
\hline $\begin{array}{l}\text { Capot-Rey's } \\
\text { aridity index }\end{array}$ & CR-AI & $\begin{array}{l}\frac{1}{2}\left(\frac{100 P}{E_{\text {pot }}}+\frac{12 P_{\mathrm{w}}}{E_{\text {pot, } \mathrm{w}}}\right) \\
P_{\mathrm{w}} \text { is precipitation of the wettest } \\
\text { month of the year (in } \mathrm{cm} / \mathrm{month} \text { ), } \\
E_{\mathrm{pot}, \mathrm{w}} \text { is potential evaporation of } \\
\text { the wettest month of the year (in } \\
\mathrm{cm} / \text { month). }\end{array}$ & $\begin{array}{l}\text { Capot-Rey } \\
\text { (1951) }\end{array}$ \\
\hline $\begin{array}{l}\text { Radiational } \\
\text { index of } \\
\text { dryness }\end{array}$ & RID & $\begin{array}{l}\frac{R}{L \times P} \\
R \text { is mean annual net radiation, } L \\
\text { is latent heat of vaporization of } \\
\text { water. }\end{array}$ & $\begin{array}{l}\text { Budyko } \\
\text { (1958) }\end{array}$ \\
\hline
\end{tabular}


Table B-1 (continued). Aridity indicators.

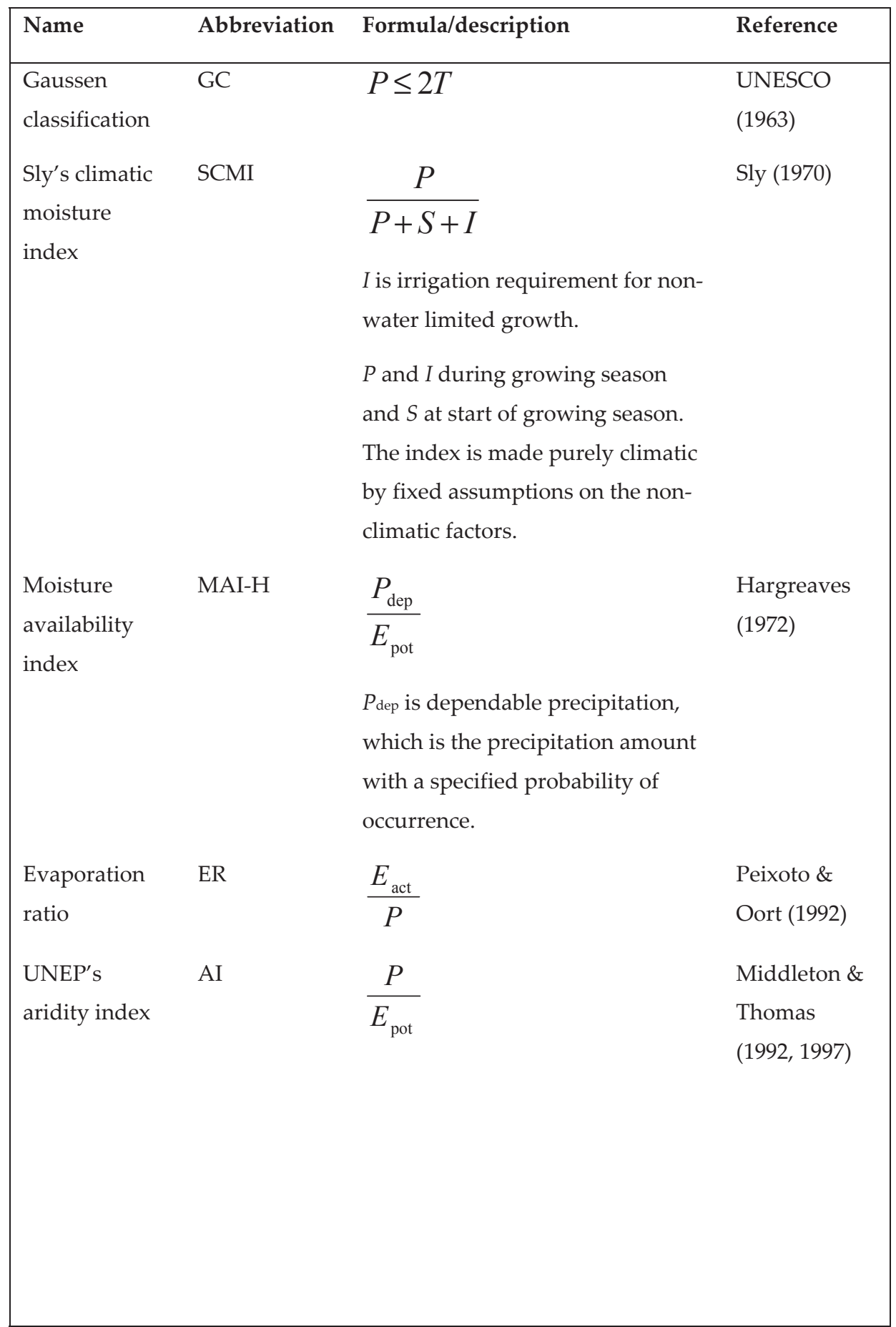


Table B-1 (continued). Aridity indicators.

\begin{tabular}{|c|c|c|c|}
\hline Name & Abbreviation & Formula/description & Reference \\
\hline $\begin{array}{l}\text { Seasonal crop } \\
\text { moisture } \\
\text { deficiency }\end{array}$ & SCMD & $\begin{array}{l}\text { Probability of seasonal crop } \\
\text { moisture deficiency based on a } \\
\text { combination of long-term } \\
\text { precipitation records and area- } \\
\text { weighted Eact of the mixture of } \\
\text { crops grown in the study area. } \\
\text { Although most crops studied by } \\
\text { Wilhelmi et al. (2002) are } \\
\text { considered well-watered (Eact = } \\
E_{\text {pot,c), for wheat and grasses Eact is }} \\
\text { estimated as the Eact associated } \\
\text { with a certain threshold yield, } \\
\text { representing so-called critical crop } \\
\text { water requirements (Wilhelmi et } \\
\text { al., 2002). }\end{array}$ & $\begin{array}{l}\text { Wilhelmi et } \\
\text { al. (2002); } \\
\text { Wilhelmi \& } \\
\text { Wilhite (2002) }\end{array}$ \\
\hline $\begin{array}{l}\text { Climatic } \\
\text { moisture } \\
\text { index }\end{array}$ & CliMI & $\begin{array}{l}\frac{P}{E_{\mathrm{pot}}}-1 \text { when } P<E_{\mathrm{pot}} \\
1-\frac{E_{\mathrm{pot}}}{P} \text { when } P \geq E_{\mathrm{pot}}\end{array}$ & $\begin{array}{l}\text { Vörösmarty } \\
\text { et al. (2005) }\end{array}$ \\
\hline $\begin{array}{l}\text { Hydrologic } \\
\text { unit } \\
\text { evaporation } \\
\text { ratio }\end{array}$ & HU-ER & $\begin{array}{l}\frac{E_{\text {act }}}{P} \\
\text { Theoretically equivalent to ER } \\
\text { (above), but applied to the level of } \\
\text { a hydrologic unit. }\end{array}$ & $\begin{array}{l}\text { Weiskel et al. } \\
\text { (2014) }\end{array}$ \\
\hline
\end{tabular}


Table B-1 (continued). Aridity indicators.

\begin{tabular}{|llll|}
\hline Name & Abbreviation & Formula/description & Reference \\
\hline Green-blue & GBI & Indicates whether vertical & Weiskel et al. \\
index & & precipitation and evaporation & $(2014)$ \\
& fluxes dominate in a hydrologic & \\
& unit (compared to lateral blue \\
& water flows) during a period of \\
& interest. Distinction between semi- \\
& arid and arid areas can be made \\
& when combined with a & \\
& precipitation map. & \\
& & \\
&
\end{tabular}

Table B-2. Agricultural drought indicators.

\begin{tabular}{|c|c|c|c|}
\hline Name & Abbreviation & Formula/description & Reference \\
\hline $\begin{array}{l}\text { Bova's drought } \\
\text { index }\end{array}$ & BDI & $\begin{array}{l}\frac{10(S+P)}{\sum T} \\
S \text { (in mm) of the top } 100 \mathrm{~cm} \text { of } \\
\text { soil at the beginning of the } \\
\text { growing season, } P \text { during } \\
\text { growing season and sum of } T \\
\text { from the first day } T \text { is above } 0 \\
{ }^{\circ} \mathrm{C} \text {. }\end{array}$ & $\begin{array}{l}\text { Bova (1941) as } \\
\text { cited by World } \\
\text { Meteorological } \\
\text { Organization } \\
(1975)\end{array}$ \\
\hline $\begin{array}{l}\text { Moisture } \\
\text { adequacy } \\
\text { index }\end{array}$ & MAI & $\frac{P+S}{E_{\text {pot }}}$ & $\begin{array}{l}\text { McGuire \& } \\
\text { Palmer (1957) }\end{array}$ \\
\hline
\end{tabular}


Table B-2 (continued). Agricultural drought indicators.

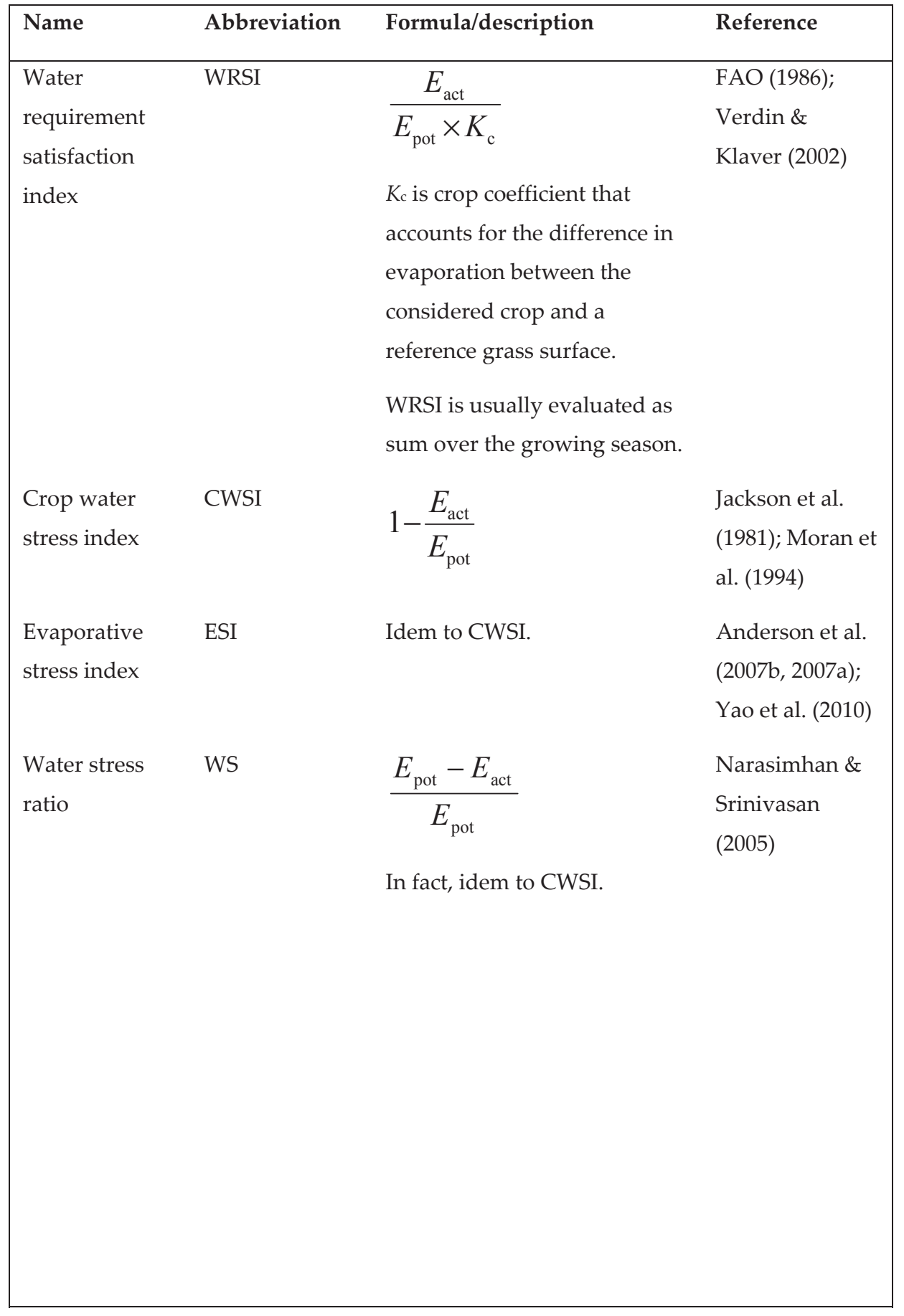


Table B-2 (continued). Agricultural drought indicators.

\begin{tabular}{|c|c|c|c|}
\hline Name & Abbreviation & Formula/description & Reference \\
\hline $\begin{array}{l}\text { Crop moisture } \\
\text { index }\end{array}$ & CMI & $\begin{array}{l}\text { Abnormal evaporation deficit, } \\
\text { defined as the difference } \\
\text { between Eact and } \\
\text { climatologically expected } \\
\text { weekly evaporation. Whereby } \\
\text { the latter is the normal value } \\
\text { adjusted up or down } \\
\text { according to the departure of } \\
\text { the week's temperature from } \\
\text { normal (Wilhite \& Glantz, } \\
\text { 1985). }\end{array}$ & Palmer (1968) \\
\hline $\begin{array}{l}\text { Stress day } \\
\text { index }\end{array}$ & SDI & $\begin{array}{l}\text { Product of a stress day factor } \\
\text { (SD) that measures the degree } \\
\text { and duration of plant water } \\
\text { deficit and a crop } \\
\text { susceptibility factor (CS), } \\
\text { which is specific for the crop } \\
\text { species and growth stage, } \\
\text { indicating a crop's } \\
\text { susceptibility to water deficit. } \\
\text { Various definitions of SD are } \\
\text { proposed based on Tract and } \\
\text { Trpot and/or leaf and soil water } \\
\text { potential. }\end{array}$ & $\begin{array}{l}\text { Hiler \& Clark } \\
(1971)\end{array}$ \\
\hline
\end{tabular}


Table B-2 (continued). Agricultural drought indicators.

\begin{tabular}{|c|c|c|c|}
\hline Name & Abbreviation & Formula/description & Reference \\
\hline $\begin{array}{l}\text { Crop-specific } \\
\text { drought index }\end{array}$ & CSDI & $\begin{array}{l}\prod_{i=1}^{n}\left(\frac{\sum E_{\mathrm{act}}}{\sum E_{\mathrm{pot}, \mathrm{c}}}\right)_{i}^{\lambda_{i}} \\
\text { Index } i \text { depicts the crop } \\
\text { growth stage. Exponent } \lambda_{\mathrm{i}} \\
\text { expresses the relative } \\
\text { sensitivity of the crop to } \\
\text { moisture stress during stage } i \text {. } \\
\text { Meyer et al. (1993) initially } \\
\text { developed the CSDI for corn. } \\
\text { Later on, the index was also } \\
\text { applied for soybean, wheat } \\
\text { and sorghum (Wu et al., } \\
\text { 2004). }\end{array}$ & $\begin{array}{l}\text { Meyer et al. } \\
\text { (1993) }\end{array}$ \\
\hline $\begin{array}{l}\text { Integrated } \\
\text { transpiration } \\
\text { deficit }\end{array}$ & DTx & $\begin{array}{l}\sum_{i=1}^{x}\left(\operatorname{Tr}_{\text {pot }}-\operatorname{Tr}_{\text {act }}\right) \\
\text { Transpiration deficit that has } \\
\text { been built up during a period } \\
\text { of } x \text { days before. }\end{array}$ & $\begin{array}{l}\text { Marletto et al. } \\
\text { (2005) }\end{array}$ \\
\hline $\begin{array}{l}\text { Actual to } \\
\text { potential } \\
\text { canopy } \\
\text { conductance }\end{array}$ & Lta & $\begin{array}{l}\frac{g_{\text {act }}}{g_{\text {pot }}} \\
\text { Ratio of actual to potential } \\
\text { canopy conductance. It } \\
\text { describes the extent to which } \\
\text { transpiration and } \\
\text { photosynthesis are co-limited } \\
\text { by soil water deficits (Gerten } \\
\text { et al., 2007). }\end{array}$ & $\begin{array}{l}\text { Gerten et al. } \\
(2005)\end{array}$ \\
\hline
\end{tabular}


Table B-2 (continued). Agricultural drought indicators.

\begin{tabular}{|c|c|c|c|}
\hline Name & Abbreviation & Formula/description & Reference \\
\hline $\begin{array}{l}\text { Water deficit } \\
\text { index }\end{array}$ & WDI & $1-\frac{\operatorname{Tr}_{\mathrm{act}}}{\operatorname{Tr}_{\text {pot }}}$ & $\begin{array}{l}\text { Woli et al. } \\
\text { (2012) }\end{array}$ \\
\hline $\begin{array}{l}\text { Agricultural } \\
\text { reference index } \\
\text { for drought }\end{array}$ & ARID & $1-\frac{\operatorname{Tr}_{\mathrm{act}}}{E_{\mathrm{pot}, \mathrm{ref}}}$ & $\begin{array}{l}\text { Woli et al. } \\
\text { (2012) }\end{array}$ \\
\hline $\begin{array}{l}\text { MODIS global } \\
\text { terrestrial } \\
\text { drought } \\
\text { severity index }\end{array}$ & DSI & $\begin{array}{l}\text { Standardized sum of the } \\
\text { standardized ratio of Eact to } \\
E_{\text {pot }} \text { and the standardized } \\
\text { normalized difference } \\
\text { vegetation index (NDVI). The } \\
\text { latter only during the snow- } \\
\text { free growing season. }\end{array}$ & Mu et al. (2013) \\
\hline
\end{tabular}


Table B-2 (continued). Agricultural drought indicators.

\begin{tabular}{|c|c|c|c|}
\hline Name & Abbreviation & Formula/description & Reference \\
\hline $\begin{array}{l}\text { Green water } \\
\text { scarcity index }\end{array}$ & GWSI & $\begin{array}{l}\frac{\min \left(P_{\text {eff }}, E_{\text {pot, }}\right)}{P_{\text {eff }}} \\
\text { Ratio of the green water } \\
\text { consumption of a 3-year crop } \\
\text { rotation (in } \mathrm{m}^{3} / \mathrm{m}^{2} / \text { rotation) } \\
\text { over the effective } \\
\text { precipitation during the same } \\
\text { period (Peff in } \mathrm{m}^{3} / \mathrm{m}^{2} / \text { rotation). } \\
P_{\text {eff represents infiltrated }} \\
\text { precipitation as a proxy for } \\
\text { crop-available green water. } \\
\text { Green water consumption is } \\
\text { defined as the minimum of } \\
P_{\text {eff } \text { and } E_{\text {pot,c. }} \text { Therefore, the }} \\
\text { index is } 1 \text { if } P_{\text {eff }} \leq E_{\text {pot, }} \text { and } \\
\text { ranges from } 0 \text { to } 1 \text { if } P_{\text {eff }}> \\
E_{\text {pot,c. It measures to which }} \\
\text { extent available green water } \\
\text { during the } 3 \text {-year period was } \\
\text { sufficient to meet the } \\
\text { evaporative demand of the } \\
\text { crop rotation during that } \\
\text { period. }\end{array}$ & $\begin{array}{l}\text { Nunez et al. } \\
\text { (2013) }\end{array}$ \\
\hline $\begin{array}{l}\text { Green water } \\
\text { stress index }\end{array}$ & GrWSI & $\frac{E_{\mathrm{act}} / E_{\mathrm{pot}}}{\overline{E_{\mathrm{act}}} / \overline{E_{\mathrm{pot}}}}$ & Wada (2013) \\
\hline
\end{tabular}


Table B-3. Absolute soil moisture indicators.

\begin{tabular}{|c|c|c|c|}
\hline Name & Abbreviation & Formula/description & Reference \\
\hline $\begin{array}{l}\text { Antecedent } \\
\text { precipitation } \\
\text { index }\end{array}$ & API & $\begin{array}{l}k \times A P I_{i-1}+P_{i} \\
A P I \text { on day } i \text { is calculated by } \\
\text { multiplying } A P I \text { of the previous } \\
\text { day with a factor } k \text { (e.g. } 0.9 \text { ) and } \\
\text { adding the } P \text { during day } i \text {. By } \\
\text { combining the amount and timing } \\
\text { of precipitation, the index is a } \\
\text { proxy for available soil moisture. }\end{array}$ & $\begin{array}{l}\text { McQuigg } \\
\text { (1954) }\end{array}$ \\
\hline $\begin{array}{l}\text { Agricultural } \\
\text { drought day }\end{array}$ & ADD & $\begin{array}{l}\left.\sum_{i=1}^{L} d a y\right|_{\theta \leq \theta_{\mathrm{WP}}} \\
L \text { is length of the period considered. }\end{array}$ & $\begin{array}{l}\text { Rickard } \\
\text { (1960) }\end{array}$ \\
\hline $\begin{array}{l}\text { Kulik's } \\
\text { drought } \\
\text { indicator }\end{array}$ & KU & $\begin{array}{l}\left.\sum d a y\right|_{S<S_{\text {thres }}} \\
S \text { in tilled layer of soil (top } 20 \mathrm{~cm} \text { ). }\end{array}$ & $\begin{array}{l}\text { Kulik (1958) } \\
\text { as cited by } \\
\text { World } \\
\text { Meteorologic } \\
\text { al } \\
\text { Organization } \\
(1975)\end{array}$ \\
\hline $\begin{array}{l}\text { Keetch-Byram } \\
\text { drought index }\end{array}$ & KBDI & $\begin{array}{l}\text { The amount of net precipitation } \\
\text { (precipitation minus evaporation) } \\
\text { that is required to fill up the soil } \\
\text { moisture to field capacity. }\end{array}$ & $\begin{array}{l}\text { Keetch \& } \\
\text { Byram (1968) }\end{array}$ \\
\hline $\begin{array}{l}\text { Soil moisture } \\
\text { drought index }\end{array}$ & SMDI & $\sum_{i=1}^{365} S$ & $\begin{array}{l}\text { Hollinger et } \\
\text { al. (1993) as } \\
\text { cited by } \\
\text { Byun \& } \\
\text { Wilhite } \\
\text { (1999) }\end{array}$ \\
\hline
\end{tabular}


Table B-3 (continued). Absolute soil moisture indicators.

\begin{tabular}{|c|c|c|c|}
\hline Name & Abbreviation & Formula/description & Reference \\
\hline $\begin{array}{l}\text { Soil moisture } \\
\text { index }\end{array}$ & SMIX & $\begin{array}{l}\int_{t 1}^{t 2} \int_{l 1}^{l 2} S d l d t \\
t 1 \text { and } t 2 \text { are usually start and end } \\
\text { of growing seasons (authors also } \\
\text { take } t 2 \text { somewhat before end of the } \\
\text { cropping period); } l 1 \text { and } l 2 \text { are the } \\
\text { soil depths over which integration } \\
\text { takes place; } l 1 \text { is the soil surface; } \\
\text { and } l 2 \text { represents the rooting depth, } \\
\text { which depends on the crop type } \\
\text { and stage of growth. }\end{array}$ & $\begin{array}{l}\text { Isard et al. } \\
\text { (1995) }\end{array}$ \\
\hline $\begin{array}{l}\text { Water stress } \\
\text { coefficient }\end{array}$ & $\mathrm{K}_{\mathrm{s}}$ & $\begin{array}{l}\frac{S_{\text {tot }}-S_{\text {depl }}}{(1-p) \times S_{\text {tot }}} \\
\text { Stot is total available soil water in } \\
\text { the root zone (mm), } S_{\text {depl is root }} \\
\text { zone depletion (mm) and } p \text { is part } \\
\text { of total available soil water in the } \\
\text { root zone that a crop can extract } \\
\text { from the root zone without } \\
\text { suffering from water stress. }\end{array}$ & $\begin{array}{l}\text { Allen et al. } \\
\text { (1998) }\end{array}$ \\
\hline $\begin{array}{l}\text { Temperature - } \\
\text { vegetation } \\
\text { dryness index }\end{array}$ & TVDI & $\begin{array}{l}\text { Surface soil moisture availability } \\
\text { based on an empirical } \\
\text { parameterization of the relationship } \\
\text { between NDVI and land surface } \\
\text { temperature (LST) derived from } \\
\text { satellite observations. }\end{array}$ & $\begin{array}{l}\text { Sandholt et } \\
\text { al. (2002) }\end{array}$ \\
\hline $\begin{array}{l}\text { Modified } \\
\text { perpendicular } \\
\text { drought index }\end{array}$ & MPDI & $\begin{array}{l}\text { Soil moisture and vegetation status } \\
\text { on the basis of near-infrared and } \\
\text { red spectral reflectance space. }\end{array}$ & $\begin{array}{l}\text { Ghulam et } \\
\text { al. (2007a); } \\
\text { Ghulam et } \\
\text { al. (2007b) }\end{array}$ \\
\hline
\end{tabular}


Table B-3 (continued). Absolute soil moisture indicators.

\begin{tabular}{|c|c|c|c|}
\hline Name & Abbreviation & Formula/description & Reference \\
\hline $\begin{array}{l}\text { Average green } \\
\text { water storage } \\
\text { availability }\end{array}$ & & $\begin{array}{l}\text { Long-term average number of } \\
\text { months in which } S>1 \mathrm{~mm} / \mathrm{m} \text {. }\end{array}$ & $\begin{array}{l}\text { Schuol et al. } \\
\text { (2008) }\end{array}$ \\
\hline $\begin{array}{l}\text { Standard } \\
\text { deviation of } \\
\text { green water } \\
\text { storage } \\
\text { availability }\end{array}$ & SD-GWS & $\begin{array}{l}\text { Standard deviation of the number } \\
\text { of months in which } S>1 \mathrm{~mm} / \mathrm{m} \text {. }\end{array}$ & $\begin{array}{l}\text { Schuol et al. } \\
\text { (2008) }\end{array}$ \\
\hline $\begin{array}{l}\text { Soil moisture } \\
\text { index }\end{array}$ & SMI & $\begin{array}{l}-5+10 \frac{\theta-\theta_{\mathrm{WP}}}{\theta_{\mathrm{FC}}-\theta_{\mathrm{WP}}} \\
\theta \text { is volumetric soil moisture } \\
\text { content }(\mathrm{cm} / \mathrm{m}), \theta_{\mathrm{WP}} \text { is volumetric } \\
\text { soil moisture content at wilting } \\
\text { point }(\mathrm{cm} / \mathrm{m}) \text { and } \theta_{\mathrm{FC}} \text { is volumetric } \\
\text { soil moisture content at field } \\
\text { capacity }(\mathrm{cm} / \mathrm{m}) \text {. }\end{array}$ & $\begin{array}{l}\text { Hunt et al. } \\
(2009)\end{array}$ \\
\hline
\end{tabular}


Table B-4. Agricultural suitability under rain-fed conditions.

\begin{tabular}{|c|c|c|c|}
\hline Name & Abbreviation & Formula/description & Reference \\
\hline $\begin{array}{l}\text { GAEZ crop- } \\
\text { specific } \\
\text { suitability } \\
\text { under rain-fed } \\
\text { conditions }\end{array}$ & GAEZ & $\begin{array}{l}\text { Crop-specific suitability under } \\
\text { rain-fed conditions is based on } \\
\text { estimates of agro-ecologically } \\
\text { attainable yields. First, agro- } \\
\text { climatically attainable yields are } \\
\text { determined based on a water } \\
\text { balance approach that calculates } \\
\text { Eact and additionally considers } \\
\text { crop water requirements and a } \\
\text { crop's sensitivity to water stress } \\
\text { during the various stages of } \\
\text { growth to calculate a yield } \\
\text { reduction factor due to water } \\
\text { limitations. Second, agro- } \\
\text { climatically attainable yields are } \\
\text { further reduced by agro-edaphic } \\
\text { constraints. }\end{array}$ & $\begin{array}{l}\text { IIASA/FAO } \\
(2012)\end{array}$ \\
\hline $\begin{array}{l}\text { GLUES crop- } \\
\text { specific } \\
\text { suitability } \\
\text { under rain-fed } \\
\text { conditions }\end{array}$ & GLUES & $\begin{array}{l}\text { Crop-specific suitability under } \\
\text { rain-fed conditions is based on a } \\
\text { fuzzy logic approach with crop- } \\
\text { specific membership functions for } \\
\text { climatic, soil and topographic } \\
\text { conditions. Yield estimates are not } \\
\text { provided by the GLUES } \\
\text { methodology. }\end{array}$ & $\begin{array}{l}\text { Zabel et al. } \\
\text { (2014) }\end{array}$ \\
\hline
\end{tabular}




\section{B.2. Relative Green Water Availability Indicators}

Relative green water availability indicators are included in Tables B-5 to B-8. The following are some often used symbols in this appendix: $E_{\mathrm{pot}}$ is potential evaporation, $E_{\text {pot,ref }}$ is potential evaporation of FAO reference crop, $P$ is precipitation, NDVI is Normalized Difference Vegetation Index.

Table B-5. Meteorological drought indicators based on precipitation only.

\begin{tabular}{|c|c|c|c|}
\hline Name & Abbreviation & Formula/description & Reference \\
\hline Days of rain & DoR & $\left.\sum d a y\right|_{P<P_{\text {thres }}}$ & $\begin{array}{l}\text { Munger } \\
\text { (1916); Kincer } \\
\text { (1919); } \\
\text { Blumenstock } \\
(1942)\end{array}$ \\
\hline $\begin{array}{l}\text { Percent of } \\
\text { average } \\
\text { precipitation }\end{array}$ & PoAP & $\frac{P}{\bar{P}}$ & $\begin{array}{l}\text { Bates } \\
\text { (1935);Hoyt } \\
\text { (1936) as cited } \\
\text { by World } \\
\text { Meteorologic } \\
\text { al } \\
\text { Organization } \\
\text { (1975) }\end{array}$ \\
\hline $\begin{array}{l}\text { Foley drought } \\
\text { index }\end{array}$ & FDI & $\begin{array}{l}\text { Cumulative deficiency (excess) of } \\
P \text { in certain month (period) } \\
\text { compared to the long-term } \\
\text { average } P \text { for that month (period), } \\
\text { expressed in thousands of annual } \\
P \text {. }\end{array}$ & $\begin{array}{l}\text { Foley (1957) } \\
\text { as cited by } \\
\text { World } \\
\text { Meteorologic } \\
\text { al } \\
\text { Organization } \\
\text { (1975) and } \\
\text { Keyantash \& } \\
\text { Dracup (2002 }\end{array}$ \\
\hline
\end{tabular}


Table B-5 (continued). Meteorological drought indicators based on precipitation only.

\begin{tabular}{|c|c|c|c|}
\hline Name & Abbreviation & Formula/description & Reference \\
\hline $\begin{array}{l}\text { Rainfall } \\
\text { anomaly index }\end{array}$ & RAI & $\begin{array}{l} \pm 3 \frac{P-\bar{P}}{\overline{P_{\text {ext }}}-\bar{P}} \\
\overline{P_{\text {ext }}} \text { is average of the } 10 \text { most } \\
\text { extreme precipitation amounts on } \\
\text { record (largest for positive and } \\
\text { smallest for negative anomalies). } \\
\text { Can be calculated on weekly, } \\
\text { monthly or annual timescale } \\
\text { (Wanders et al., 2010). }\end{array}$ & $\begin{array}{l}\text { Van Rooy } \\
(1965) \text { as cited } \\
\text { by Keyantash } \\
\text { \& Dracup } \\
\text { (2002) }\end{array}$ \\
\hline Deciles & - & $\begin{array}{l}\text { In which decile of a long-term } \\
\text { record of precipitation events a } \\
\text { certain precipitation event falls. }\end{array}$ & $\begin{array}{l}\text { Gibbs and } \\
\text { Maher (1967) } \\
\text { as cited by } \\
\text { Wilhite \& } \\
\text { Glantz (1985) }\end{array}$ \\
\hline $\begin{array}{l}\text { Bhalme and } \\
\text { Mooley } \\
\text { drought index }\end{array}$ & BMDI & $\begin{array}{l}\text { The percentage departure of } \\
\text { monthly rainfall from the long- } \\
\text { term mean weighted by the } \\
\text { reciprocal of the coefficient of } \\
\text { variation. }\end{array}$ & $\begin{array}{l}\text { Bhalme \& } \\
\text { Mooley } \\
(1980)\end{array}$ \\
\hline $\begin{array}{l}\text { Standardized } \\
\text { precipitation } \\
\text { index }\end{array}$ & SPI & $\begin{array}{l}\text { Precipitation deviation for a } \\
\text { normally distributed probability } \\
\text { density with a mean of zero and } \\
\text { standard deviation of } 1 .\end{array}$ & $\begin{array}{l}\text { McKee et al. } \\
\text { (1993) }\end{array}$ \\
\hline $\begin{array}{l}\text { National } \\
\text { rainfall index }\end{array}$ & NRI & $\begin{array}{l}\text { National average of annual } \\
\text { precipitation weighed according to } \\
\text { the long-term average } \\
\text { precipitation of all individual } \\
\text { stations in a country. }\end{array}$ & $\begin{array}{l}\text { Gommes \& } \\
\text { Petrassi } \\
\text { (1994) }\end{array}$ \\
\hline
\end{tabular}


Table B-5 (continued). Meteorological drought indicators based on precipitation only.

\begin{tabular}{|llll|}
\hline Name & Abbreviation & Formula/description & Reference \\
\hline Effective & EDI & Ratio of the difference between the & Byun \& \\
drought index & & 5-day-running mean of effective & Wilhite (1999) \\
& & $\begin{array}{l}\text { precipitation (EP, calculated from } \\
\text { equations based on precipitation) }\end{array}$ & \\
& & and its climatological mean value & \\
& & over the standard deviation of this & \\
& & difference, measured per day. & \\
Precipitation & PCI & & $P-P_{\text {min }}$ \\
condition & & $P_{\text {max }}-P_{\text {min }}$ & Du et al. \\
index & & $P$ inputs refer to monthly amounts. & \\
& & &
\end{tabular}


Table B-6. Meteorological drought indicators based on precipitation and a measure of potential evaporation.

\begin{tabular}{|c|c|c|c|}
\hline Name & Abbreviation & Formula/description & Reference \\
\hline $\begin{array}{l}\text { Palmer } \\
\text { drought } \\
\text { severity index }\end{array}$ & PDSI & $\begin{array}{l}\text { Accumulated weighted differences } \\
\text { between actual precipitation and } \\
\text { precipitation requirement of } \\
\text { evaporation (Wilhite and Glantz, } \\
\text { 1985). }\end{array}$ & $\begin{array}{l}\text { Palmer } \\
\text { (1965); Alley } \\
\text { (1984) }\end{array}$ \\
\hline $\begin{array}{l}\text { Reconnaissanc } \\
\text { e drought } \\
\text { index }\end{array}$ & RDI & $\begin{array}{l}\text { Standardized ratio of } P \text { to } E_{\text {pot }} \\
\text { based on a log-normal } \\
\text { distribution. }\end{array}$ & $\begin{array}{l}\text { Tsakiris \& } \\
\text { Vangelis } \\
\text { (2005); } \\
\text { Tsakiris et al. } \\
\text { (2007) }\end{array}$ \\
\hline $\begin{array}{l}\text { Standardized } \\
\text { precipitation } \\
\text { evapotranspir } \\
\text { ation index }\end{array}$ & SPEI & $\begin{array}{l}\text { Standardized difference between } P \\
\text { and } E_{\text {pot }} \text { based on a log-logistic } \\
\text { distribution. }\end{array}$ & $\begin{array}{l}\text { Vicente- } \\
\text { Serrano et al. } \\
(2009)\end{array}$ \\
\hline $\begin{array}{l}\text { Water surplus } \\
\text { variability } \\
\text { index }\end{array}$ & WSVI & $\begin{array}{l}\text { Standardized difference between } P \\
\text { and } E_{\text {pot,ref }} \text { based on a logistic } \\
\text { distribution. }\end{array}$ & $\begin{array}{l}\text { Gocic \& } \\
\text { Trajkovic } \\
(2014)\end{array}$ \\
\hline
\end{tabular}


Table B-7. Vegetation drought indicators.

\begin{tabular}{|c|c|c|c|}
\hline Name & Abbreviation & Formula/description & Reference \\
\hline $\begin{array}{l}\text { Normalized } \\
\text { difference } \\
\text { vegetation } \\
\text { index anomaly }\end{array}$ & NDVIA & $\mathrm{NDVI}-\overline{\mathrm{NDVI}}$ & $\begin{array}{l}\text { Tucker } \\
(1979) ; \\
\text { Myneni et al. } \\
\text { (1998) }\end{array}$ \\
\hline $\begin{array}{l}\text { Vegetation } \\
\text { condition index }\end{array}$ & $\mathrm{VCI}$ & $\begin{array}{l}\frac{\mathrm{NDVI}-\mathrm{NDVI}_{\text {min }}}{\mathrm{NDVI}_{\text {max }}-\mathrm{NDVI}_{\text {min }}} \\
\mathrm{NDVI}_{\text {min }} \text { is multiyear minimum } \\
\text { of smoothed weekly NDVI and } \\
\text { NDVImax is multiyear maximum }_{\text {of smoothed weekly NDVI. }}\end{array}$ & $\begin{array}{l}\text { Kogan }(1990, \\
1995)\end{array}$ \\
\hline $\begin{array}{l}\text { Vegetation } \\
\text { health index }\end{array}$ & VHI & $\begin{array}{l}a \cdot \mathrm{VCI}+b \cdot \mathrm{TCI} \\
a \text { is coefficient quantifying share } \\
\text { of VCI contribution in the } \\
\text { combined condition, } b \text { is } \\
\text { coefficient quantifying share of } \\
\text { TCI contribution in the combined } \\
\text { condition, TCI is temperature } \\
\text { condition index and } \mathrm{VCI} \text { is } \\
\text { vegetation condition index. }\end{array}$ & Kogan (2001) \\
\hline $\begin{array}{l}\text { Standardized } \\
\text { vegetation } \\
\text { index }\end{array}$ & SVI & $\begin{array}{l}\text { NDVI deviation for a normally } \\
\text { distributed probability density } \\
\text { with a mean of zero and } \\
\text { standard deviation of } 1 .\end{array}$ & $\begin{array}{l}\text { Peters et al. } \\
(2002)\end{array}$ \\
\hline $\begin{array}{l}\text { Normalized } \\
\text { difference } \\
\text { water index } \\
\text { anomaly }\end{array}$ & NDWIA & $\begin{array}{l}\text { Adaptation of NDVI (Gao, 1996) } \\
\text { compared to its multi-year mean. }\end{array}$ & $\begin{array}{l}\text { Gu et al. } \\
(2007)\end{array}$ \\
\hline
\end{tabular}


Table B-7 (continued). Vegetation drought indicators.

\begin{tabular}{|c|c|c|c|}
\hline Name & Abbreviation & Formula/description & Reference \\
\hline $\begin{array}{l}\text { Enhanced } \\
\text { vegetation } \\
\text { index anomaly }\end{array}$ & EVIA & $\begin{array}{l}\text { EVI anomaly. EVI is an } \\
\text { improvement over NDVI, which } \\
\text { keeps sensitivity over densely } \\
\text { vegetated areas (Huete et al., } \\
\text { 1994). }\end{array}$ & $\begin{array}{l}\text { Saleska et al. } \\
\text { (2007) }\end{array}$ \\
\hline $\begin{array}{l}\text { Percent of } \\
\text { average } \\
\text { seasonal } \\
\text { greenness }\end{array}$ & PASG & $\begin{array}{l}\frac{\mathrm{SG}}{\overline{\mathrm{SG}}} \times 100 \% \\
\text { SG is seasonal greenness, defined } \\
\text { as accumulated NDVI above } \\
\text { background NDVI during a } \\
\text { specified period. }\end{array}$ & $\begin{array}{l}\text { Brown et al. } \\
(2008)\end{array}$ \\
\hline
\end{tabular}


Table B-8. Relative soil moisture availability indicators.

\begin{tabular}{|c|c|c|c|}
\hline Name & Abbreviation & Formula/description & Reference \\
\hline $\begin{array}{l}\text { Soil water } \\
\text { deficit }\end{array}$ & SD (\& SMDI) & $\begin{array}{l}\text { Difference between mean } \\
\text { weekly and long-term median } S \text {, } \\
\text { divided by the difference } \\
\text { between long-term minimum } \\
\text { (maximum) and median } S \text {. }\end{array}$ & $\begin{array}{l}\text { Narasimhan \& } \\
\text { Srinivasan } \\
(2005)\end{array}$ \\
\hline $\begin{array}{l}\text { Palmer Z- } \\
\text { index (a.k.a. } \\
\text { Palmer } \\
\text { moisture } \\
\text { anomaly } \\
\text { index) }\end{array}$ & PZI & $\begin{array}{l}\text { Moisture anomaly for the } \\
\text { current period from the climate- } \\
\text { average moisture conditions for } \\
\text { that period. }\end{array}$ & $\begin{array}{l}\text { Palmer (1965); } \\
\text { Alley (1984) }\end{array}$ \\
\hline $\begin{array}{l}\text { Soil moisture } \\
\text { anomaly } \\
\text { index }\end{array}$ & SMAI & $\begin{array}{l}\frac{\theta-\bar{\theta}}{\bar{\theta}} \times 100 \% \\
\theta \text { is volumetric soil moisture } \\
\text { content. }\end{array}$ & $\begin{array}{l}\text { Bergman et al. } \\
\text { (1988) }\end{array}$ \\
\hline
\end{tabular}




\section{Appendix C:}

\section{An Appendix to Chapter 5}

\section{C.1. Area Used for Roundwood Production}

The area used for roundwood production was estimated based on the Global Forest Resources Assessment 2015 (FRA) (Köhl et al., 2015). In the domain "Production", FRA distinguishes two categories, namely production forest area $\left(A_{\text {prod}}\right)$ and multiple use forest area ( $A$ muluse). The latter is defined as "the forest area designated for more than one purpose and where none of these alone is considered as the predominant designated function" (Köhl et al., 2015). The portion of Amuluse that is used for roundwood production $(\alpha)$ varies per region, but exact figures are unknown. For instance, Köhl et al. (2015) deduce from wood removals and the reported $A_{\text {prod }}$ and $A$ muluse per region that North America produces most wood in multiple use forests, while in Europe most production likely takes place in primary production forest. To account for these different utilization rates of multiple use forest, we calculate $\alpha$ per region as $A_{\text {muluse }} /\left(A_{\text {prod }}+A_{\text {muluse }}\right)$. The reasoning is that regions that mainly report $A$ muluse, probably use a larger fraction of that area for production compared to regions that mainly report $A$ prod. We then calculate per country the forest area used for production as $A_{\text {prod }}+\alpha A_{\text {muluse }}$ for the FRA reporting years 1990, 2000, 2005 and 2010, and take the total forest area in a country if $A_{\text {prod }}$ and $A$ muluse are not reported. Finally, we linearly interpolate between these years and scale the wood harvested area maps (Section 5.2.4 of main text) to these values per country, using the 1990 scaling factor for 1961-1989. See Figure C-1 for the area development over time per biome.

\section{C.2. Determination of Dominant Forest Type and Climate Zone per Grid Cell}

For each $30 \times 30$ arc minute grid cell in our wood harvest maps, we determined the dominant climate and forest type. The dominant climate was determined by means of a frequency count on the $5 \times 5$ arc minute resolution map by Van Velthuizen et al. (2007) that distinguishes the following ten climates: tropics; subtropics, summer rainfall; subtropics, winter rainfall; temperate, oceanic; temperate, sub-continental; temperate, continental; boreal, oceanic. In case of an equal count, we took the colder climate as the dominant one. Loveland et al. (2009) distinguish five different forest types: evergreen needleleaf forest; evergreen broadleaf forest; deciduous needleleaf forest; deciduous broadleaf forest; mixed forest. The dominant forest type was determined by picking the forest type with the maximum fractional cover in a grid cell. In rare cases where multiple 
types have the same and maximum fractional cover, we arbitrarily selected the first one occurring in the alphabet as the dominant type.

\section{C.3. Average Tree Species Yield per Climate Zone}

Firstly, we obtained from Brown (2000) the yields for pine, eucalyptus, larch and oak for 84 countries by taking the average of the mentioned yield ranges. Note that for many of these countries only yield estimates for one or two of the mentioned species was available. Secondly, we determined per country the dominant climate zone in the areas used for roundwood production (using a similar procedure as used to determine the dominant climate per grid cell). Thirdly, we calculated the long-term maximum sustainable annual yield per species and climate zone by taking the average of the yield per species for all countries with the same dominant climate. Therein, we exclude New Zealand due to its very different climate and deviating yield range. The following exceptions apply:

- For pine in the (sub)tropics, we took the average for the Pinus caribaea variety as given in text by Brown (2000). This species is grown throughout the tropics and in parts of the subtropics (Ugalde \& Pérez, 2001). Brown (2000) mentions yields between 12 and $15 \mathrm{~m}^{3} / \mathrm{ha} / \mathrm{y}$ for Pinus caribaea in Central and South America. The average of this range $\left(13.5 \mathrm{~m}^{3} / \mathrm{ha} / \mathrm{y}\right)$ is about the same as the upper limit of the pine yield range in temperate and boreal countries in the mid-latitudes (m³/ha/y) (Brown, 2000).

- For deciduous broadleaf forest in the (sub)tropics, eucalyptus is seen as the characteristic species rather than oak, which is not likely to occur in these climate zones.

- For larch in the subtropics, the upper limit of the yield range given in Brown (2000) is applied. Generally, higher yields are achieved in (sub)tropical regions compared to temperate and boreal regions Brown (2000).

- For larch in the boreal and arctic zones, the lower limit of the yield range given in Brown (2000) is applied.

\section{C.4. Maximum Height of Capillary Rise}

The maximum height of capillary rise $\left(d_{c a p, \max }, \mathrm{in} \mathrm{mm}\right)$ is estimated using the empirical relation by Peck et al. (1974) as cited by Liu et al. (2014):

$$
d_{\mathrm{cap}, \max }=\frac{C}{e \times D_{10}}
$$


in which $C$ is a constant assumed to be $30 \mathrm{~mm}^{2}, e$ the void ratio, and $D_{10}$ the grain size in $\mathrm{mm}$. $D_{10}$ is estimated as the square root of the saturated hydraulic conductivity ( $\left.K_{\text {sat }}\right)$ of the soil (in cm/s). This is the result of rearranging the formula by Hazen (1982) as cited by Urumović \& Urumović Sr (2016) for $D_{10}$ and applying a constant that is typically assumed 1 . Ksat and $e$ for the dominant soil type in a $30 \times 30$ arc minute grid cell have been obtained from de Lannoy et al. (2014). To estimate $e$ we needed the porosity, which we estimated following de Lannoy et al. (2014) by dividing the soil moisture content at saturation by 0.93 .

\section{C.5. Derivation of the Equation for the Volumetric Moisture Content of Harvested Wood}

The amount of water in harvested wood is usually expressed as the moisture content, which is the ratio of the weight of water ( $\left.w_{\text {water, }} \mathbf{t}\right)$ over the oven-dry weight of the wood ( $\left.w_{\text {od, }} t\right)$ (Simpson, 1998). The moisture content of wood varies with the temperature and relative humidity of the environment. When these conditions remain constant, the equilibrium moisture content $(E M C, \mathrm{t} / \mathrm{t})$ will eventually be attained (Simpson, 1998). We are interested in the volumetric moisture content of harvested wood $\left(\mathrm{m}^{3}\right.$ water per $\mathrm{m}^{3}$ wood):

$$
f_{\text {water }}=\frac{v_{\text {water }}}{v_{\text {wood }}}
$$

In which $v_{\text {water }}\left(\mathrm{m}^{3}\right)$ is the volume of water incorporated in the wood and $v_{\text {wood }}\left(\mathrm{m}^{3}\right)$ is the volume of freshly harvested wood. Since $v_{\text {water }}$ is unknown, we need to rewrite Equation C-2 based on the EMC and the wood density $\left(d, \mathrm{~m}^{3} / \mathrm{t}\right)$ :

$$
\begin{aligned}
& E M C=\frac{w_{\text {water }}}{w_{\text {od }}} \\
& d=\frac{w_{\text {od }}}{v_{\text {wood }}}
\end{aligned}
$$

Substituting Equation C-3 in Equation C-4 after rearranging for $v_{\text {wood }}$ gives:

$$
v_{\text {wood }}=\frac{w_{\text {water }}}{d \times E M C}
$$


Assuming that $1 \mathrm{~m}^{3}$ water weighs 1 tonne and substituting Equation C-5 in Equation C2, yields:

$$
f_{\text {water }}=d \times E M C
$$

\section{C.6. Value Fraction of Roundwood Production}

Firstly, we distribute the monetary values per hectare of the ecosystem services over production and non-production forests for the reference year 2010 (Table C-1). Secondly, we scale the values back in time and disaggregate them spatially, based on the actual volumes of roundwood produced and the intensity of forest exploitation.

The intensity of forest exploitation ( $f_{\text {int, }}$ dimensionless) is estimated for grid cell $x$ in year $t$ as the ratio of the actual roundwood production $\left(P_{\text {act, }}\right.$ in $\left.\mathrm{m}^{3} / \mathrm{y}\right)$ over the maximum sustainable wood production of the forest $\left(P_{\text {sus, }}\right.$ in $\left.\mathrm{m}^{3} / \mathrm{y}\right)$. The latter is estimated as the long-term maximum sustainable wood yield $\left(Y_{\text {sus, }}\right.$ in $\left.\mathrm{m}^{3} / \mathrm{m}^{2} / \mathrm{y}\right)$ times the area used for roundwood production $\left(A_{\mathrm{rw}}\right.$, in $\left.\mathrm{m}^{2}\right)$ :

$$
f_{\text {int }}[x, t]=\operatorname{MAX}\left(1, \frac{P_{\text {act }}[x, t]}{Y_{\text {sus }}[x] \times A_{\mathrm{rw}}[x, t]}\right)
$$

This ratio is in fact equal to the ratio of the actual annual yield ( $Y$ act $)$ over the maximum sustainable annual yield as suggested by Van Oel \& Hoekstra (2012). The ratio is also similar to the forest harvesting intensity defined by Levers et al. (2014), which is the ratio of the harvested timber volume over the net annual increment (which equals gross annual increment minus natural losses). 
Table C-1. Ecosystem service values for the reference year 2010. Values in 2007 US dollars.

\begin{tabular}{|c|c|c|c|c|c|c|}
\hline Biome & $\begin{array}{l}\text { Tropi- } \\
\text { cal } \\
\text { forests }^{a}\end{array}$ & $\begin{array}{l}\text { Tem- } \\
\text { perate/ } \\
\text { boreal } \\
\text { forests }^{a}\end{array}$ & $\begin{array}{l}\text { Tropi- } \\
\text { cal } \\
\text { produc- } \\
\text { tion } \\
\text { forests }\end{array}$ & $\begin{array}{l}\text { Tem- } \\
\text { perate/ } \\
\text { boreal } \\
\text { produc- } \\
\text { tion } \\
\text { forests }\end{array}$ & $\begin{array}{l}\text { Tropi- } \\
\text { cal non- } \\
\text { produc- } \\
\text { tion } \\
\text { forests }\end{array}$ & $\begin{array}{l}\text { Tem- } \\
\text { perate/ } \\
\text { boreal } \\
\text { non- } \\
\text { produc- } \\
\text { tion } \\
\text { forests }\end{array}$ \\
\hline Area (106 ha) & 1258 & 3003 & $898^{\mathrm{b}}$ & $1027^{b}$ & $1219^{b}$ & $871^{b}$ \\
\hline $\begin{array}{l}\text { Average intensity of } \\
\text { forest exploitation in } \\
2010(-)\end{array}$ & & & 0.21 & 0.17 & - & - \\
\hline $\begin{array}{l}\text { Actual roundwood } \\
\text { production in } 2010\left(10^{9}\right. \\
\left.\mathrm{m}^{3} / \mathrm{y}\right)\end{array}$ & & & 2.5 & 1.0 & - & - \\
\hline 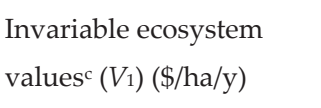 & 4348 & 869 & 4348 & 869 & 4348 & 869 \\
\hline 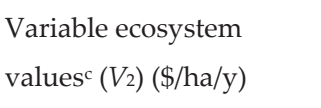 & 949 & 2087 & 820 & 1907 & 1044 & 2300 \\
\hline $\begin{array}{l}\text { Roundwood production } \\
\left(V_{3}\right)(\$ / \mathrm{ha} / \mathrm{y})\end{array}$ & 84 & 181 & $118^{\mathrm{d}}$ & $529^{d}$ & - & - \\
\hline $\begin{array}{l}\text { Roundwood production } \\
\left(V_{3}^{*}\right)\left(\$ / \mathrm{m}^{3} \operatorname{wood} / \mathrm{y}\right)\end{array}$ & & & $43^{\mathrm{e}}$ & $521^{\mathrm{e}}$ & - & - \\
\hline
\end{tabular}

a Data from Costanza et al. (2014) for 2011.

b Estimated for 2010 as described in Section C.1. Non-production forest area estimated as the total forest area for the year 2010 according the Global Forest Resources Assessment (Keenan et al., 2015) minus the estimated production forest area.

c See main text for the ecosystem services that are included in this category.

d Estimated by first calculating the total value of $V_{3}(\$ / y)$ for the reference year according to Costanza et al. (2014) (by multiplying the value per ha with the area, both as reported by Costanza et al. (2014)) and subsequently dividing the total value of $V_{3}$ by the estimated production forest area in 2010.

e Estimated by first calculating the total value of $V_{3}(\$ / y)$ for the reference year (by multiplying the value per ha with the area) and subsequently dividing the total value of $V_{3}$ by the actual roundwood production in 2010. 
In Table C-1, $V_{2}$ for production forests is estimated based on the average intensity of forest exploitation in 2010 - assuming a linear relation between $V_{2}$ and $f_{\text {int }}$ and furthermore assuming that $V_{2}=0$ when $f_{\text {int }}=1$ - such that the area-weighted average of $V_{2}$ for production and non-production forests equals the original $V_{2}$ for the entire biome as reported by Costanza et al. (2014) (i.e. columns 2 and 3 in Table C-1). This yields the following biome-specific relationships between $V_{2}$ and $f_{\text {int }}$ (plotted in Figure C-1):

$$
V_{2}=a f_{\text {int }}+c
$$

With $a=-1044$ and $c=1044$ for tropical production forests and $a=-2300$ and $c=2300$ for temperate/boreal production forests.

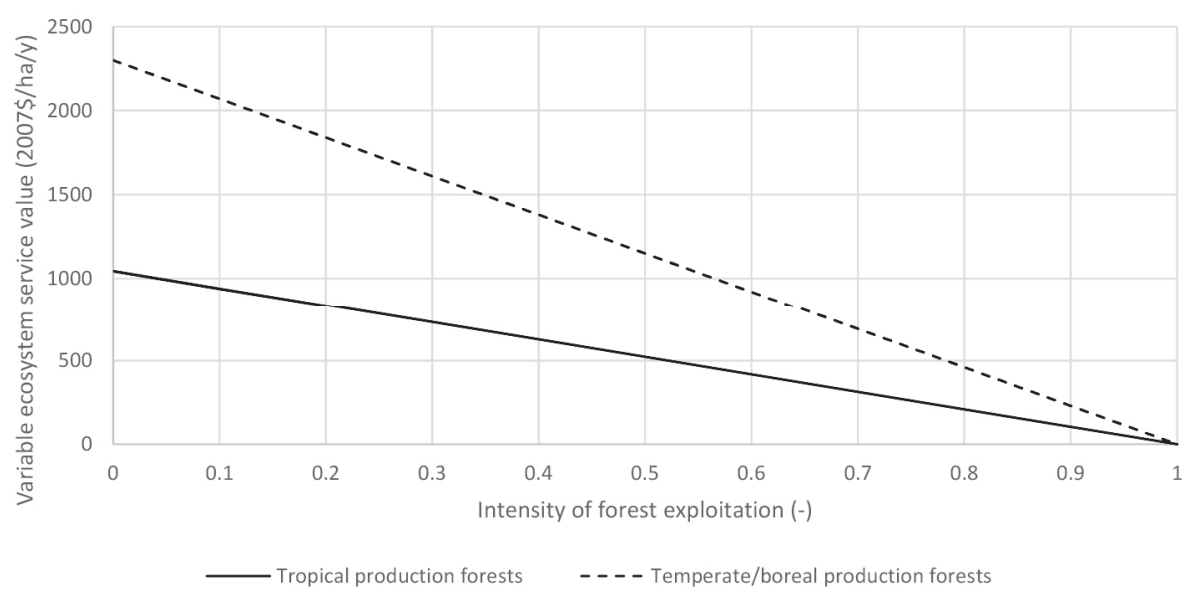

Figure C-1. Relationship between the intensity of forest exploitation and the variable ecosystem service value according to Equation C-8.

We calculate, per biome, the total value of ecosystem services in grid cell $x$ in year $t$ as follows:

$$
V_{\text {tot }}[x, t]=V_{1}+V_{2}[x, t]+V_{3}[x, t]=V_{1}+\operatorname{MAX}\left(0, a f_{\mathrm{int}}[x, t]+c\right)+10^{4} V_{3}^{*} \frac{P_{\mathrm{act}}[x, t]}{A_{\mathrm{rw}}[x, t]}
$$

The factor $10^{4}$ is to convert $A_{\mathrm{rw}}$ in $\mathrm{m}^{2}$ to ha. Note that $V_{3}{ }^{*}$ is in $\$ / \mathrm{m}^{3}$ wood/y and that the last term as a whole is in $\$ / \mathrm{ha} / \mathrm{y}$. 
Ultimately, we calculate the value fraction of roundwood production ( $f_{\text {value,rw, }}$ dimensionless) in grid cell $x$ in year $t$ per biome as the ratio of the value of roundwood production per ha to the total value per ha:

$$
f_{\text {value,rw }}[x, t]=\frac{V_{3}[x, t]}{V_{1}+V_{2}[x, t]+V_{3}[x, t]}
$$

\section{C.7. Temporal Development of Variables Affecting the Water Use Attributed to Roundwood Production}

Figure C-2 provides supporting information for the explanation given in Section 5.3.1 of the main text.
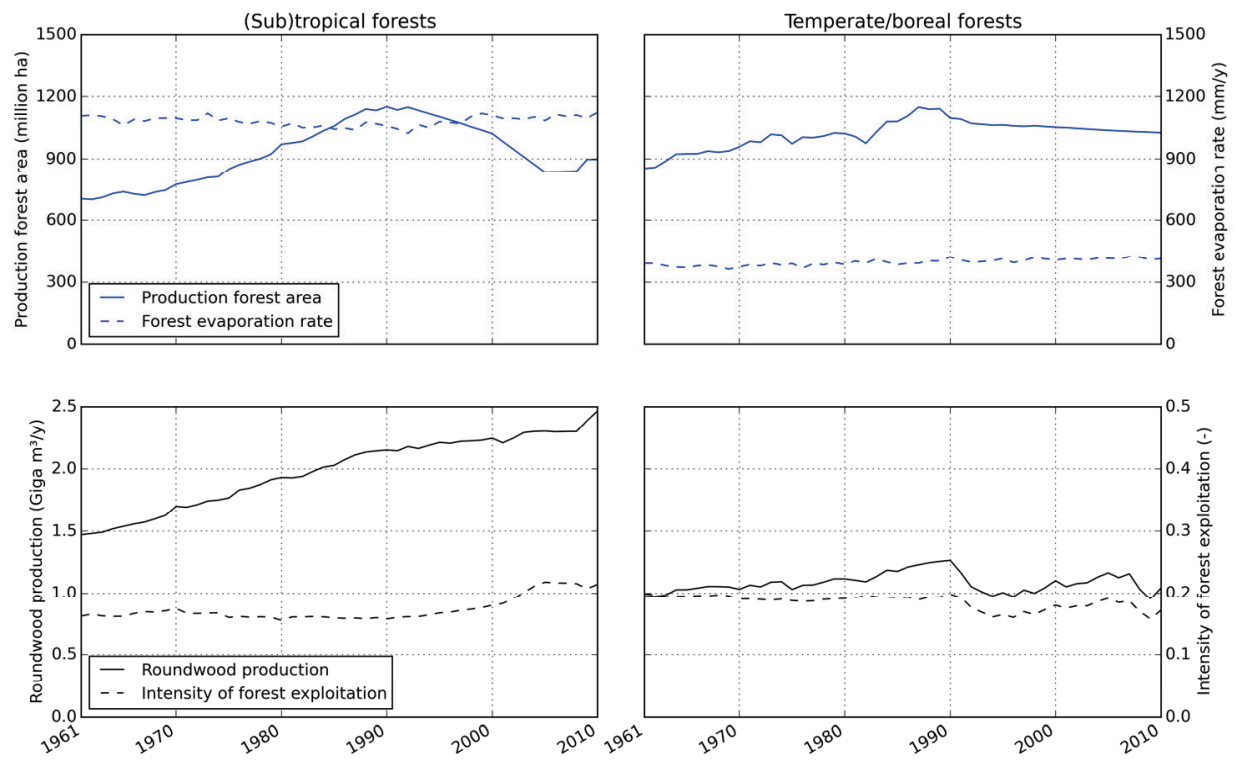

Figure C-2. Temporal development of the total production forest area, area-weighted average forest evaporation rate, total roundwood production and area-weighted average intensity of forest exploitation per biome. The left hand side and right hand side graphs share the primary and secondary y-axes and the legend. 


\section{C.8. Annual Actual Forest Evaporation}

The mean actual forest evaporation $(\mathrm{mm} / \mathrm{y})$ per forest type and climate zone are given in Table C-2.

Table C-2. Mean actual forest evaporation ( $\mathrm{mm} / \mathrm{y}$ ) of various forest types per climate zone based on an arithmetic average. Period: 1961-2010.

\begin{tabular}{|c|c|c|c|c|c|}
\hline Climate zone & $\begin{array}{l}\text { Evergreen } \\
\text { needleleaf }\end{array}$ & $\begin{array}{l}\text { Evergreen } \\
\text { broadleaf }\end{array}$ & $\begin{array}{l}\text { Deciduous } \\
\text { needleleaf }\end{array}$ & $\begin{array}{l}\text { Deciduous } \\
\text { broadleaf }\end{array}$ & Mixed \\
\hline Tropics & 1152 & 1226 & - & 1191 & 1094 \\
\hline $\begin{array}{l}\text { Subtropics, } \\
\text { summer rainfall }\end{array}$ & 809 & 764 & 311 & 790 & 796 \\
\hline $\begin{array}{l}\text { Subtropics, winter } \\
\text { rainfall }\end{array}$ & 644 & 681 & 673 & 598 & 572 \\
\hline Temperate & 469 & 623 & 295 & 622 & 437 \\
\hline $\begin{array}{l}\text { Boreal, oceanic \& } \\
\text { sub-continental }\end{array}$ & 373 & - & 331 & - & 374 \\
\hline $\begin{array}{l}\text { Boreal, continental } \\
\& \text { arctic }\end{array}$ & 305 & - & 216 & - & 289 \\
\hline
\end{tabular}




\section{Appendix D:}

\section{An Appendix to Chapter 6}

\section{D.1. Tables}

Table D-1. Materials used for estimating the green water footprint of livestock grazing.

\begin{tabular}{|c|c|c|}
\hline Variable & Source dataset(s) & Operation(s)/remarks \\
\hline $\begin{array}{l}\text { Area of permanent } \\
\text { meadows and pastures } \\
(5 \times 5 \text { arc minute })\end{array}$ & $\begin{array}{l}\text { Klein Goldewijk et al. } \\
\text { (2011) }\end{array}$ & $\begin{array}{l}\text { Linear interpolation between } 2000 \\
\text { and } 2005 \text { and constant for } 2005- \\
2009 .\end{array}$ \\
\hline $\begin{array}{l}\text { Area of harvested } \\
\text { fodder grasses }(5 \times 5 \\
\text { arc minute) }\end{array}$ & Portmann et al. (2010) & $\begin{array}{l}\text { Clipped with the area of } \\
\text { permanent meadows and } \\
\text { pastures and then scaled to } \\
\text { national annual statistics on } \\
\text { harvested area of fodder grasses. }\end{array}$ \\
\hline $\begin{array}{l}\text { National annual } \\
\text { statistics on harvested } \\
\text { area of fodder grasses }\end{array}$ & FAO (2016a) & $\begin{array}{l}\text { Sum of FAOSTAT crop codes: } 639 \\
\text { (grasses, nes), } 640 \text { (clover), and } \\
50 \% \text { of } 651 \text { (mixed grasses and } \\
\text { legumes). }\end{array}$ \\
\hline $\begin{array}{l}\text { Density of cattle, goats } \\
\text { and sheep } \\
\text { representative of the } \\
\text { year } 2006 \text { ( } 30 \times 30 \text { arc } \\
\text { second) }\end{array}$ & Robinson et al. (2014) & $\begin{array}{l}\text { See Section 6.2. For asses, camels, } \\
\text { horses, llamas and mules, we } \\
\text { used the distribution of cattle due } \\
\text { to lack of animal-specific } \\
\text { distribution maps. }\end{array}$ \\
\hline $\begin{array}{l}\text { Density of buffaloes } \\
\text { representative of the } \\
\text { year } 2005 \text { ( } 3 \times 3 \text { arc } \\
\text { minute) }\end{array}$ & $\begin{array}{l}\text { Wint \& Robinson } \\
\text { (2007) }\end{array}$ & See Section 6.2.4. \\
\hline $\begin{array}{l}\text { Ruminant production } \\
\text { systems representative } \\
\text { of the year } 2011 \text { ( } 30 x \\
30 \text { arc second) }\end{array}$ & Robinson et al. (2011) & $\begin{array}{l}\text { The production systems are } \\
\text { grouped into the two systems } \\
\text { (pastoral and mixed/landless) as } \\
\text { distinguished by Bouwman et al. } \\
\text { (2005). }\end{array}$ \\
\hline
\end{tabular}


Table D-1 (continued). Materials used for estimating the green water footprint of livestock grazing.

\begin{tabular}{|c|c|c|}
\hline Variable & Source dataset(s) & Operation(s)/remarks \\
\hline $\begin{array}{l}\text { Production per system } \\
\text { in } 1970 \text { and } 1995 \text { (per } \\
\text { animal category, per } \\
\text { world region) }\end{array}$ & Bouwman et al. (2005) & $\begin{array}{l}\text { Annual rate of change of the } \\
\text { fraction of production in the } \\
\text { pastoral system is derived. This } \\
\text { rate is applied to the estimated } \\
\text { livestock distribution map, } \\
\text { assuming no change if a grid cell } \\
\text { is classified as either } 100 \% \\
\text { pastoral or } 100 \% \text { mixed/landless } \\
\text { by Robinson et al. (2011). }\end{array}$ \\
\hline $\begin{array}{l}\text { Actual annual } \\
\text { evaporation rate of } \\
\text { grazed grass ( } 30 \text { × } 30 \\
\text { arc minute) }\end{array}$ & $\begin{array}{l}\text { Rolinski et al. (2017): } \\
\text { daily grazing option } \\
\text { under livestock } \\
\text { density that results in } \\
\text { the highest grass yield. }\end{array}$ & $\begin{array}{l}\text { Assumed to be fully green (no } \\
\text { irrigation). }\end{array}$ \\
\hline $\begin{array}{l}\text { Maximum sustainable } \\
\text { grass yield ( } 30 \times 30 \text { arc } \\
\text { minute) }\end{array}$ & $\begin{array}{l}\text { Rolinski et al. (2017): } \\
\text { daily grazing option } \\
\text { under livestock } \\
\text { density that results in } \\
\text { the highest grass yield. }\end{array}$ & $\begin{array}{l}\text { Conversion from carbon mass } \\
\text { units }(\mathrm{C}) \text { to grass dry matter (DM) } \\
\text { using } \mathrm{C}=0.45 \mathrm{DM} \text {. If in a grid cell } \\
\text { that is grazed according to our } \\
\text { estimates the maximum } \\
\text { sustainable grass yield is zero, we } \\
\text { set it to } 0.0001 \mathrm{t} \text { dry matter/ha/y. }\end{array}$ \\
\hline $\begin{array}{l}\text { National annual } \\
\text { statistics on meat/milk } \\
\text { production (per animal } \\
\text { category) }\end{array}$ & FAO (2016c) & $\begin{array}{l}\text { The total meat/milk production } \\
\text { per animal category is distributed } \\
\text { over the two production systems } \\
\text { based on the number of heads per } \\
\text { system. }\end{array}$ \\
\hline
\end{tabular}


Table D-1 (continued). Materials used for estimating the green water footprint of livestock grazing.

\begin{tabular}{|c|c|c|}
\hline Variable & Source dataset(s) & Operation(s)/remarks \\
\hline $\begin{array}{l}\text { Feed conversion } \\
\text { efficiencies (per world } \\
\text { region, per animal } \\
\text { category, per } \\
\text { production system) }\end{array}$ & Bouwman et al. (2005) & $\begin{array}{l}\text { Linear interpolation between } \\
\text { values reported by Bouwman et } \\
\text { al. (2005)for } 1995 \text { and } 2030 \text {. }\end{array}$ \\
\hline $\begin{array}{l}\text { Fraction of grass in } \\
\text { animal feed (per world } \\
\text { region, per animal } \\
\text { category, per } \\
\text { production system) }\end{array}$ & Bouwman et al. (2005) & $\begin{array}{l}\text { Linear interpolation between } \\
\text { values reported by Bouwman et } \\
\text { al. (2005) for } 1995 \text { and } 2030 \text {. }\end{array}$ \\
\hline $\begin{array}{l}\text { National annual } \\
\text { statistics on } \\
\text { production of fodder } \\
\text { grasses }\end{array}$ & FAO (2016a) & $\begin{array}{l}\text { Sum of FAOSTAT crop codes: } 639 \\
\text { (grasses, nes), } 640 \text { (clover), and } \\
50 \% \text { of } 651 \text { (mixed grasses and } \\
\text { legumes). Assuming that reported } \\
\text { weights represent fresh weight } \\
\text { incl. } 15 \% \text { moisture. }\end{array}$ \\
\hline $\begin{array}{l}\text { Value fraction of meat } \\
\text { and milk production } \\
\text { from grazing pastures }\end{array}$ & Costanza et al. (2014) & See Section 6.2.5. \\
\hline
\end{tabular}


Table D-2. Ecosystem service values for the reference year 2011. Values are in 2007 US dollars.

\begin{tabular}{|c|c|c|c|}
\hline & $\begin{array}{l}\text { Grass- } \\
\text { lands }\end{array}$ & $\begin{array}{l}\text { Grazed } \\
\text { grass- } \\
\text { lands }\end{array}$ & $\begin{array}{l}\text { Non- } \\
\text { grazed } \\
\text { grass- } \\
\text { lands }\end{array}$ \\
\hline Area in 2011 (106 ha) & 4,418 & 3,111 & 1,307 \\
\hline Average intensity of grazing $(\alpha)$ in $2011(-)$ & - & 0.35 & - \\
\hline $\begin{array}{l}\text { Actual meat and milk production from grazing livestock } \\
\text { in } 2011\left(10^{6} \mathrm{t} / \mathrm{y}\right)\end{array}$ & - & 820 & - \\
\hline Ecosystem values that are invariable with $\alpha^{\mathrm{b}}\left(V_{1}\right)(\$ / \mathrm{ha} / \mathrm{y})$ & 1,603 & 1,569 & 1,569 \\
\hline $\begin{array}{l}\text { Ecosystem values that are inversely proportional to } \alpha^{c} \\
\left(V_{2}\right)(\$ / \mathrm{ha} / \mathrm{y})\end{array}$ & 1,317 & $1,168^{\mathrm{d}}$ & $1,788^{\mathrm{d}}$ \\
\hline Value of meat and milk productione $\left(V_{3}\right)(\$ /$ ha/y) & 1,246 & $1,769^{f}$ & - \\
\hline Value of meat and milk production $\left(V_{3}{ }^{*}\right)(\$ / t / y)$ & & $6,682 \mathrm{~g}$ & - \\
\hline
\end{tabular}

a Data from Costanza et al. (2014) for 2011.

b Services included in this category: gas regulation, climate regulation, water regulation, water supply, nutrient cycling, waste treatment, genetic resources, cultural.

c Services included in this category: erosion control, soil formation, pollination, biological control, habitat/refugia, recreation.

d Estimated based on the average $\alpha$ in 2011 - assuming a linear relation between $V_{2}$ and $\beta$ and furthermore assuming that $V_{2}=0$ when $\alpha=1$ - such that the area-weighted average of $V_{2}$ for grazed and non-grazed lands equals $V_{2}$ for the entire biome (column 2), resulting in the relationship: $V_{2}=-$ $\delta \alpha+\delta$ with $\delta=1,788$. This equation is used to estimate $V_{2}$ per country per year.

e We assume that the value of the services food production and raw materials on grasslands primarily reflect the value of meat and milk production.

${ }^{\mathrm{f}}$ Estimated by first calculating the total value of $V_{3}(\$ / y)$ for the reference year according to Costanza et al. (2014), by multiplying the value per ha with the area, both as reported by Costanza et al. (2014) and subsequently dividing the total value of $V_{3}$ by the estimated grazed land area in 2011. We estimate $V_{3}$ per country per year as $\left[V_{3}^{*}\right]^{*} Q / A$ where $A$ is the grazed pasture area (ha) and $Q$ is the country total meat and milk production $(\mathrm{t} / \mathrm{y})$.

$\mathrm{g}$ Estimated by first calculating the total value of $V_{3}(\$ / y)$ for the reference year and subsequently dividing the total value of $V_{3}$ by the actual meat and milk production from grazing livestock in 2011. 
Table D-3. Green water scarcity and actual and maximum sustainable green water footprints per country.

\begin{tabular}{|c|c|c|c|c|}
\hline Country & $\begin{array}{l}\text { Actual } \\
\text { green water } \\
\text { footprint } \\
\left(\mathrm{km}^{3} / \mathrm{y}\right)\end{array}$ & $\begin{array}{l}\text { Maximum } \\
\text { sustainable } \\
\text { green water } \\
\text { footprint } \\
\left(\mathrm{km}^{3} / \mathrm{y}\right)\end{array}$ & $\begin{array}{l}\text { Green water } \\
\text { scarcity (-) a }\end{array}$ & $\begin{array}{l}\text { Overshoot } \\
\text { as \% of } \\
\text { actual green } \\
\text { water } \\
\text { footprint } \\
(\%)\end{array}$ \\
\hline Afghanistan & 16 & 27 & 0.58 & 16 \\
\hline Albania & 3.5 & 2.8 & 1.3 & 58 \\
\hline Algeria & 22 & 47 & 0.46 & 5.0 \\
\hline American Samoa & 0 & 0 & 1.0 & 0 \\
\hline Andorra & 0.020 & 0.0046 & 4.5 & 86 \\
\hline Angola & 17 & 170 & 0.099 & 13 \\
\hline Antigua and Barbuda & 0.072 & 0.14 & 0.51 & 36 \\
\hline Argentina & 260 & 460 & 0.58 & 6.7 \\
\hline Armenia & 3.5 & 4.1 & 0.86 & 31 \\
\hline Australia & 170 & 740 & 0.23 & 16 \\
\hline Austria & 22 & 32 & 0.68 & 4.9 \\
\hline Azerbaijan & 8.8 & 12 & 0.71 & 24 \\
\hline Bahamas & 0.11 & 0.37 & 0.29 & 48 \\
\hline Bahrain & 0.019 & 0.019 & 0.97 & 0 \\
\hline Bangladesh & 70 & 67 & 1.0 & 13 \\
\hline Barbados & 0.21 & 0.30 & 0.69 & 36 \\
\hline Belarus & 34 & 58 & 0.58 & 7.2 \\
\hline Belgium & 6.8 & 5.7 & 1.2 & 35 \\
\hline Belize & 0.81 & 1.4 & 0.58 & 43 \\
\hline Benin & 12 & 26 & 0.48 & 5.0 \\
\hline
\end{tabular}


Table D-3 (continued). Green water scarcity and actual and maximum sustainable green water footprints per country.

\begin{tabular}{|c|c|c|c|c|}
\hline Country & $\begin{array}{l}\text { Actual } \\
\text { green water } \\
\text { footprint } \\
\left(\mathrm{km}^{3} / \mathrm{y}\right)\end{array}$ & $\begin{array}{l}\text { Maximum } \\
\text { sustainable } \\
\text { green water } \\
\text { footprint } \\
\left(\mathrm{km}^{3} / \mathrm{y}\right)\end{array}$ & $\begin{array}{l}\text { Green water } \\
\text { scarcity (-) a }\end{array}$ & $\begin{array}{l}\text { Overshoot } \\
\text { as } \% \text { of } \\
\text { actual green } \\
\text { water } \\
\text { footprint } \\
(\%)\end{array}$ \\
\hline Bhutan & 1.7 & 0.61 & 2.8 & 85 \\
\hline Bolivia & 21 & 110 & 0.20 & 30 \\
\hline $\begin{array}{l}\text { Bosnia and } \\
\text { Herzegovina }\end{array}$ & 8.9 & 18 & 0.50 & 13 \\
\hline Botswana & 1.7 & 23 & 0.072 & 7.1 \\
\hline Brazil & 870 & 1700 & 0.51 & 14 \\
\hline British Virgin Islands & 0.0020 & 0.0020 & 1.0 & 0 \\
\hline Brunei & 0.41 & 0.25 & 1.6 & 50 \\
\hline Bulgaria & 22 & 29 & 0.76 & 13 \\
\hline Burkina Faso & 25 & 68 & 0.37 & 7.6 \\
\hline Burundi & 6.5 & 8.6 & 0.75 & 20 \\
\hline Cambodia & 16 & 22 & 0.73 & 21 \\
\hline Cameroon & 32 & 45 & 0.70 & 41 \\
\hline Canada & 250 & 1000 & 0.25 & 6.2 \\
\hline Cape Verde & 0.17 & 0.11 & 1.5 & 58 \\
\hline Cayman Islands & 0.016 & 0.00061 & 26 & 96 \\
\hline $\begin{array}{l}\text { Central African } \\
\text { Republic }\end{array}$ & 7.6 & 45 & 0.17 & 8.9 \\
\hline Chad & 16 & 82 & 0.19 & 6.6 \\
\hline Chile & 27 & 43 & 0.63 & 21 \\
\hline China & 960 & 1500 & 0.65 & 9.2 \\
\hline
\end{tabular}


Table D-3 (continued). Green water scarcity and actual and maximum sustainable green water footprints per country.

\begin{tabular}{|c|c|c|c|c|}
\hline Country & $\begin{array}{l}\text { Actual } \\
\text { green water } \\
\text { footprint } \\
\left(\mathrm{km}^{3} / \mathrm{y}\right)\end{array}$ & $\begin{array}{l}\text { Maximum } \\
\text { sustainable } \\
\text { green water } \\
\text { footprint } \\
\left(\mathrm{km}^{3} / \mathrm{y}\right)\end{array}$ & $\begin{array}{l}\text { Green water } \\
\text { scarcity (-) a }\end{array}$ & $\begin{array}{l}\text { Overshoot } \\
\text { as } \% \text { of } \\
\text { actual green } \\
\text { water } \\
\text { footprint } \\
(\%)\end{array}$ \\
\hline Colombia & 160 & 230 & 0.68 & 55 \\
\hline Comoros & 0.92 & 0.16 & 5.9 & 84 \\
\hline Congo & 1.8 & 32 & 0.055 & 9.0 \\
\hline Congo, DRC & 35 & 190 & 0.18 & 14 \\
\hline Cook Islands & 0 & 0 & 1.0 & 0 \\
\hline Costa Rica & 19 & 6.4 & 3.0 & 78 \\
\hline Côte d'Ivoire & 49 & 77 & 0.64 & 16 \\
\hline Croatia & 12 & 18 & 0.70 & 21 \\
\hline Cuba & 27 & 23 & 1.2 & 41 \\
\hline Cyprus & 0.44 & 0.19 & 2.3 & 72 \\
\hline Czech Republic & 24 & 23 & 1.0 & 24 \\
\hline Denmark & 9.1 & 6.3 & 1.4 & 44 \\
\hline Djibouti & 0.15 & 0.13 & 1.2 & 29 \\
\hline Dominica & 0.24 & 0.12 & 2.0 & 54 \\
\hline Dominican Republic & 14 & 6.5 & 2.2 & 71 \\
\hline Ecuador & 46 & 6.6 & 7.0 & 91 \\
\hline Egypt & 7.5 & 6.3 & 1.2 & 17 \\
\hline El Salvador & 9.6 & 11 & 0.88 & 16 \\
\hline Equatorial Guinea & 0.96 & 2.2 & 0.43 & 47 \\
\hline
\end{tabular}


Table D-3 (continued). Green water scarcity and actual and maximum sustainable green water footprints per country.

\begin{tabular}{|c|c|c|c|c|}
\hline Country & $\begin{array}{l}\text { Actual } \\
\text { green water } \\
\text { footprint } \\
\left(\mathrm{km}^{3} / \mathrm{y}\right)\end{array}$ & $\begin{array}{l}\text { Maximum } \\
\text { sustainable } \\
\text { green water } \\
\text { footprint } \\
\left(\mathrm{km}^{3} / \mathrm{y}\right)\end{array}$ & $\begin{array}{l}\text { Green water } \\
\text { scarcity (-) a }\end{array}$ & $\begin{array}{l}\text { Overshoot } \\
\text { as \% of } \\
\text { actual green } \\
\text { water } \\
\text { footprint } \\
(\%)\end{array}$ \\
\hline Eritrea & 2.6 & 7.2 & 0.37 & 2.6 \\
\hline Estonia & 6.9 & 7.8 & 0.88 & 33 \\
\hline Ethiopia & 97 & 150 & 0.64 & 21 \\
\hline Faroe Islands & 0.0014 & 0.000059 & 23 & 96 \\
\hline Fiji & 2.7 & 0.75 & 3.6 & 86 \\
\hline Finland & 35 & 81 & 0.43 & 6.5 \\
\hline France & 130 & 140 & 0.91 & 17 \\
\hline French Guiana & 0.38 & 0.45 & 0.85 & 63 \\
\hline French Polynesia & 0 & 0 & 1.0 & 0 \\
\hline Gabon & 1.9 & 28 & 0.068 & 11 \\
\hline Georgia & 8.6 & 18 & 0.47 & 21 \\
\hline Germany & 93 & 52 & 1.8 & 60 \\
\hline Ghana & 37 & 66 & 0.56 & 19 \\
\hline Greece & 23 & 20 & 1.2 & 30 \\
\hline Grenada & 0.15 & 0.0013 & 110 & 99 \\
\hline Guadeloupe & 0.47 & 0.11 & 4.4 & 89 \\
\hline Guam & 0.13 & 0.083 & 1.6 & 36 \\
\hline Guatemala & 22 & 14 & 1.5 & 70 \\
\hline Guinea & 19 & 61 & 0.31 & 14 \\
\hline
\end{tabular}


Table D-3 (continued). Green water scarcity and actual and maximum sustainable green water footprints per country.

\begin{tabular}{|c|c|c|c|c|}
\hline Country & $\begin{array}{l}\text { Actual } \\
\text { green water } \\
\text { footprint } \\
\left(\mathrm{km}^{3} / \mathrm{y}\right)\end{array}$ & $\begin{array}{l}\text { Maximum } \\
\text { sustainable } \\
\text { green water } \\
\text { footprint } \\
\left(\mathrm{km}^{3} / \mathrm{y}\right)\end{array}$ & $\begin{array}{l}\text { Green water } \\
\text { scarcity (-) a }\end{array}$ & $\begin{array}{l}\text { Overshoot } \\
\text { as } \% \text { of } \\
\text { actual green } \\
\text { water } \\
\text { footprint } \\
(\%)\end{array}$ \\
\hline Guinea-Bissau & 2.8 & 7.3 & 0.39 & 18 \\
\hline Guyana & 2.7 & 29 & 0.095 & 5.7 \\
\hline Haiti & 8.9 & 3.3 & 2.7 & 65 \\
\hline Honduras & 15 & 11 & 1.5 & 59 \\
\hline Hungary & 26 & 30 & 0.86 & 5.3 \\
\hline Iceland & 0.59 & 5.8 & 0.10 & 9.5 \\
\hline India & 820 & 890 & 0.92 & 11 \\
\hline Indonesia & 340 & 320 & 1.1 & 33 \\
\hline Iran & 72 & 100 & 0.69 & 10 \\
\hline Iraq & 11 & 17 & 0.66 & 8.2 \\
\hline Ireland & 14 & 19 & 0.78 & 6.3 \\
\hline Israel & 2.5 & 2.5 & 1.0 & 23 \\
\hline Italy & 70 & 77 & 0.90 & 19 \\
\hline Jamaica & 4.2 & 0.86 & 4.9 & 82 \\
\hline Japan & 52 & 130 & 0.40 & 27 \\
\hline Jordan & 1.1 & 0.97 & 1.1 & 31 \\
\hline Kazakhstan & 72 & 270 & 0.27 & 2.6 \\
\hline Kenya & 56 & 75 & 0.74 & 21 \\
\hline Kuwait & 0.16 & 0.12 & 1.4 & 33 \\
\hline
\end{tabular}


Table D-3 (continued). Green water scarcity and actual and maximum sustainable green water footprints per country.

\begin{tabular}{|c|c|c|c|c|}
\hline Country & $\begin{array}{l}\text { Actual } \\
\text { green water } \\
\text { footprint } \\
\left(\mathrm{km}^{3} / \mathrm{y}\right)\end{array}$ & $\begin{array}{l}\text { Maximum } \\
\text { sustainable } \\
\text { green water } \\
\text { footprint } \\
\left(\mathrm{km}^{3} / \mathrm{y}\right)\end{array}$ & $\begin{array}{l}\text { Green water } \\
\text { scarcity (-) a }\end{array}$ & $\begin{array}{l}\text { Overshoot } \\
\text { as \% of } \\
\text { actual green } \\
\text { water } \\
\text { footprint } \\
(\%)\end{array}$ \\
\hline Kyrgyzstan & 11 & 23 & 0.46 & 11 \\
\hline Laos & 6.9 & 13 & 0.53 & 40 \\
\hline Latvia & 12 & 14 & 0.85 & 23 \\
\hline Lebanon & 1.2 & 1.2 & 0.99 & 26 \\
\hline Lesotho & 1.7 & 7.1 & 0.24 & 27 \\
\hline Liberia & 4.8 & 11 & 0.43 & 27 \\
\hline Libya & 3.0 & 6.5 & 0.47 & 2.3 \\
\hline Liechtenstein & 0.056 & 0.028 & 2.0 & 78 \\
\hline Lithuania & 14 & 15 & 0.94 & 23 \\
\hline Luxembourg & 0.76 & 0.89 & 0.86 & 11 \\
\hline Macedonia & 3.8 & 6.6 & 0.57 & 13 \\
\hline Madagascar & 29 & 100 & 0.29 & 49 \\
\hline Malawi & 13 & 17 & 0.75 & 43 \\
\hline Malaysia & 89 & 54 & 1.6 & 49 \\
\hline Mali & 26 & 90 & 0.29 & 6.6 \\
\hline Malta & 0.058 & 0.030 & 1.9 & 71 \\
\hline Martinique & 0.42 & 0.22 & 1.9 & 72 \\
\hline Mauritania & 3.6 & 6.7 & 0.54 & 0 \\
\hline Mauritius & 0.80 & 0.46 & 1.7 & 69 \\
\hline
\end{tabular}


Table D-3 (continued). Green water scarcity and actual and maximum sustainable green water footprints per country.

\begin{tabular}{|c|c|c|c|c|}
\hline Country & $\begin{array}{l}\text { Actual } \\
\text { green water } \\
\text { footprint } \\
\left(\mathrm{km}^{3} / \mathrm{y}\right)\end{array}$ & $\begin{array}{l}\text { Maximum } \\
\text { sustainable } \\
\text { green water } \\
\text { footprint } \\
\left(\mathrm{km}^{3} / \mathrm{y}\right)\end{array}$ & $\begin{array}{l}\text { Green water } \\
\text { scarcity (-) a }\end{array}$ & $\begin{array}{l}\text { Overshoot } \\
\text { as \% of } \\
\text { actual green } \\
\text { water } \\
\text { footprint } \\
(\%)\end{array}$ \\
\hline Mexico & 180 & 230 & 0.77 & 39 \\
\hline Micronesia & 0 & 0 & 1.0 & 0 \\
\hline Moldova & 8.0 & 9.1 & 0.87 & 2.7 \\
\hline Monaco & 0.0025 & 0.0025 & 1.0 & 0 \\
\hline Mongolia & 2.4 & 48 & 0.049 & 9.9 \\
\hline Montenegro & 3.4 & 3.8 & 0.90 & 29 \\
\hline Montserrat & 0.014 & 0.014 & 1.0 & 0 \\
\hline Morocco & 31 & 42 & 0.73 & 14 \\
\hline Mozambique & 26 & 210 & 0.12 & 12 \\
\hline Myanmar & 81 & 95 & 0.85 & 24 \\
\hline Namibia & 2.4 & 28 & 0.085 & 3.5 \\
\hline Nepal & 27 & 15 & 1.8 & 51 \\
\hline Netherlands & 8.7 & 3.4 & 2.5 & 67 \\
\hline New Caledonia & 0.17 & 0.23 & 0.77 & 71 \\
\hline New Zealand & 66 & 40 & 1.6 & 52 \\
\hline Nicaragua & 16 & 27 & 0.61 & 33 \\
\hline Niger & 48 & 54 & 0.89 & 1.1 \\
\hline Nigeria & 210 & 300 & 0.70 & 11 \\
\hline Niue & 0 & 0 & 1.0 & 0 \\
\hline
\end{tabular}


Table D-3 (continued). Green water scarcity and actual and maximum sustainable green water footprints per country.

\begin{tabular}{|c|c|c|c|c|}
\hline Country & $\begin{array}{l}\text { Actual } \\
\text { green water } \\
\text { footprint } \\
\left(\mathrm{km}^{3} / \mathrm{y}\right)\end{array}$ & $\begin{array}{l}\text { Maximum } \\
\text { sustainable } \\
\text { green water } \\
\text { footprint } \\
\left(\mathrm{km}^{3} / \mathrm{y}\right)\end{array}$ & $\begin{array}{l}\text { Green water } \\
\text { scarcity (-) a }\end{array}$ & $\begin{array}{l}\text { Overshoot } \\
\text { as \% of } \\
\text { actual green } \\
\text { water } \\
\text { footprint } \\
(\%)\end{array}$ \\
\hline North Korea & 18 & 45 & 0.41 & 3.9 \\
\hline Norway & 9.3 & 43 & 0.22 & 25 \\
\hline Oman & 0.58 & 0.44 & 1.3 & 37 \\
\hline Pakistan & 57 & 62 & 0.91 & 8.5 \\
\hline Palau & 0 & 0.0092 & 0 & 0 \\
\hline Panama & 7.5 & 5.4 & 1.4 & 71 \\
\hline Papua New Guinea & 8.9 & 21 & 0.42 & 56 \\
\hline Paraguay & 42 & 130 & 0.32 & 3.6 \\
\hline Peru & 29 & 91 & 0.32 & 55 \\
\hline Philippines & 120 & 44 & 2.6 & 67 \\
\hline Poland & 84 & 100 & 0.83 & 14 \\
\hline Portugal & 15 & 15 & 1.0 & 15 \\
\hline Puerto Rico & 2.6 & 1.1 & 2.4 & 66 \\
\hline Qatar & 0.057 & 0.063 & 0.90 & 0 \\
\hline Réunion & 0.35 & 0.12 & 2.9 & 80 \\
\hline Romania & 60 & 73 & 0.83 & 7.9 \\
\hline Russia & 520 & 1900 & 0.27 & 6.6 \\
\hline Rwanda & 9.5 & 7.2 & 1.3 & 37 \\
\hline $\begin{array}{l}\text { Saint Pierre et } \\
\text { Miquelon }\end{array}$ & 0.00041 & 0.00041 & 1.0 & 0 \\
\hline
\end{tabular}


Table D-3 (continued). Green water scarcity and actual and maximum sustainable green water footprints per country.

\begin{tabular}{|c|c|c|c|c|}
\hline Country & $\begin{array}{l}\text { Actual } \\
\text { green water } \\
\text { footprint } \\
\left(\mathrm{km}^{3} / \mathrm{y}\right)\end{array}$ & $\begin{array}{l}\text { Maximum } \\
\text { sustainable } \\
\text { green water } \\
\text { footprint } \\
\left(\mathrm{km}^{3} / \mathrm{y}\right)\end{array}$ & $\begin{array}{l}\text { Green water } \\
\text { scarcity (-) a }\end{array}$ & $\begin{array}{l}\text { Overshoot } \\
\text { as } \% \text { of } \\
\text { actual green } \\
\text { water } \\
\text { footprint } \\
(\%)\end{array}$ \\
\hline Samoa & 0 & 0.07 & 0 & 0 \\
\hline San Marino & 0.004 & 0.02 & 0.2 & 0 \\
\hline Sao Tome and Principe & 0.22 & 0.13 & 1.7 & 51 \\
\hline Saudi Arabia & 5.5 & 5.2 & 1.1 & 15 \\
\hline Senegal & 10 & 24 & 0.42 & 4.2 \\
\hline Serbia & 18 & 25 & 0.69 & 3.8 \\
\hline Seychelles & 0.012 & 0 & 1.0 & 100 \\
\hline Sierra Leone & 5.7 & 13 & 0.43 & 17 \\
\hline Singapore & 0.32 & 0.32 & 0.99 & 0 \\
\hline Slovakia & 10 & 12 & 0.85 & 18 \\
\hline Slovenia & 5.1 & 6 & 0.85 & 40 \\
\hline Solomon Is. & 0.75 & 0.94 & 0.80 & 68 \\
\hline Somalia & 20 & 30 & 0.65 & 7.3 \\
\hline South Africa & 65 & 150 & 0.44 & 20 \\
\hline South Korea & 18 & 36 & 0.50 & 25 \\
\hline South Sudan & 51 & 150 & 0.34 & 8.0 \\
\hline Spain & 83 & 89 & 0.93 & 11 \\
\hline Sri Lanka & 21 & 7.8 & 2.7 & 73 \\
\hline St. Kitts and Nevis & 0.064 & 0.00069 & 92 & 99 \\
\hline
\end{tabular}


Table D-3 (continued). Green water scarcity and actual and maximum sustainable green water footprints per country.

\begin{tabular}{|c|c|c|c|c|}
\hline Country & $\begin{array}{l}\text { Actual } \\
\text { green water } \\
\text { footprint } \\
\left(\mathbf{k m}^{3} / \mathbf{y}\right)\end{array}$ & $\begin{array}{l}\text { Maximum } \\
\text { sustainable } \\
\text { green water } \\
\text { footprint } \\
\left(\mathrm{km}^{3} / \mathrm{y}\right)\end{array}$ & $\begin{array}{l}\text { Green water } \\
\text { scarcity (-) a }\end{array}$ & $\begin{array}{l}\text { Overshoot } \\
\text { as \% of } \\
\text { actual green } \\
\text { water } \\
\text { footprint } \\
(\%)\end{array}$ \\
\hline St. Lucia & 0.016 & 0.063 & 0.25 & 0 \\
\hline $\begin{array}{l}\text { St. Vincent and the } \\
\text { Grenadines }\end{array}$ & 0.13 & 0.14 & 0.91 & 0 \\
\hline Sudan & 67 & 140 & 0.47 & 2.0 \\
\hline Suriname & 0.58 & 7.2 & 0.081 & 56 \\
\hline Swaziland & 1.6 & 5.2 & 0.31 & 16 \\
\hline Sweden & 52 & 110 & 0.47 & 9.8 \\
\hline Switzerland & 9.7 & 8.0 & 1.2 & 46 \\
\hline Syria & 21 & 23 & 0.91 & 3.6 \\
\hline Taiwan & 5.7 & 4.2 & 1.3 & 52 \\
\hline Tajikistan & 4.9 & 8.6 & 0.57 & 7.5 \\
\hline Tanzania & 52 & 170 & 0.31 & 31 \\
\hline Thailand & 120 & 120 & 1.0 & 24 \\
\hline The Gambia & 1.3 & 3.0 & 0.41 & 0 \\
\hline Timor Leste & 1.2 & 0.24 & 5.0 & 90 \\
\hline Togo & 7.2 & 13 & 0.55 & 13 \\
\hline Tonga & 0 & 0.083 & 0 & 0 \\
\hline Trinidad and Tobago & 0.91 & 0.43 & 2.1 & 69 \\
\hline Tunisia & 19 & 22 & 0.86 & 3.9 \\
\hline Turkey & 120 & 170 & 0.74 & 13 \\
\hline
\end{tabular}


Table D-3 (continued). Green water scarcity and actual and maximum sustainable green water footprints per country.

\begin{tabular}{|c|c|c|c|c|}
\hline Country & $\begin{array}{l}\text { Actual } \\
\text { green water } \\
\text { footprint } \\
\left(\mathrm{km}^{3} / \mathrm{y}\right)\end{array}$ & $\begin{array}{l}\text { Maximum } \\
\text { sustainable } \\
\text { green water } \\
\text { footprint } \\
\left(\mathrm{km}^{3} / \mathrm{y}\right)\end{array}$ & $\begin{array}{l}\text { Green water } \\
\text { scarcity (-) a }\end{array}$ & $\begin{array}{l}\text { Overshoot } \\
\text { as } \% \text { of } \\
\text { actual green } \\
\text { water } \\
\text { footprint } \\
(\%)\end{array}$ \\
\hline Turkmenistan & 9.5 & 24 & 0.40 & 10 \\
\hline Uganda & 52 & 66 & 0.78 & 13 \\
\hline Ukraine & 130 & 160 & 0.83 & 5.6 \\
\hline United Arab Emirates & 2.6 & 2.6 & 1.0 & 3.3 \\
\hline United Kingdom & 61 & 48 & 1.3 & 42 \\
\hline United States & 1300 & 1900 & 0.71 & 11 \\
\hline $\begin{array}{l}\text { United States Virgin } \\
\text { Islands }\end{array}$ & 0.062 & 0.10 & 0.60 & 0 \\
\hline Uruguay & 37 & 68 & 0.54 & 9.4 \\
\hline Uzbekistan & 27 & 29 & 0.91 & 5.8 \\
\hline Vanuatu & 1.0 & 0.46 & 2.2 & 78 \\
\hline Venezuela & 47 & 110 & 0.43 & 33 \\
\hline Vietnam & 76 & 59 & 1.3 & 37 \\
\hline Wallis and Futuna & 0 & 0 & 1.0 & 0 \\
\hline Yemen & 4.5 & 4.1 & 1.1 & 24 \\
\hline Zambia & 12 & 79 & 0.15 & 16 \\
\hline Zimbabwe & 18 & 67 & 0.26 & 13 \\
\hline
\end{tabular}

a If the maximum sustainable green water footprint is zero, green water scarcity is mathematically undefined. Since in such cases no green water remains to be allocated to human activities, we then set green water scarcity to 1 . 
Table D-4. Global green water footprint $\left(W F_{\mathrm{g}}\right)$ of grazing of this study (column on right hand side) compared to estimates from previous studies.

\begin{tabular}{|c|c|c|c|}
\hline Previous studies & Period & $\begin{array}{l}\text { Global } W F_{\mathrm{g}} \text { of } \\
\text { grazing }\left(\mathrm{km}^{3} / \mathrm{y}\right)\end{array}$ & $\begin{array}{l}\text { Global } W F_{\mathrm{g}} \text { of } \\
\text { grazing in this } \\
\text { studyb }\left(\mathrm{km}^{3} / \mathrm{y}\right)\end{array}$ \\
\hline Postel et al. (1996) a & 1995 & 5,800 & 2,413 \\
\hline De Fraiture et al. (2007) ${ }^{\mathrm{b}}$ & 2000 & 840 & 2,620 \\
\hline Rost et al. (2008) a & 1971-2002 & 8,258 & 2,200 \\
\hline Hanasaki et al. (2010) a & 1985-1999 & 12,960 & 2,323 \\
\hline Mekonnen \& Hoekstra (2012b) ${ }^{b}$ & 1996-2005 & 913 & 2,683 \\
\hline
\end{tabular}

a Refers to total evaporation from grazing lands.

${ }^{\mathrm{b}}$ Relates to the grass actually consumed.

\section{D.2. Figures}
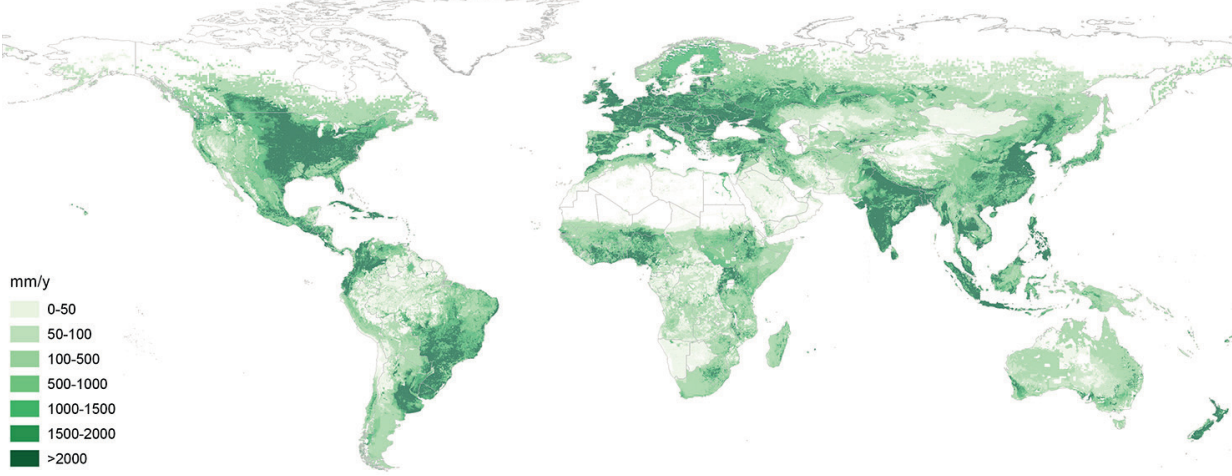

Figure D-1. Total green water footprint in $\mathrm{mm} / \mathrm{y}$ on a $5 \times 5$ arc minute grid. Sum of the green water footprints (in $\mathrm{m}^{3} / \mathrm{y}$ ) of crop production, livestock grazing, wood production and urban areas, divided by the grid cell area. 


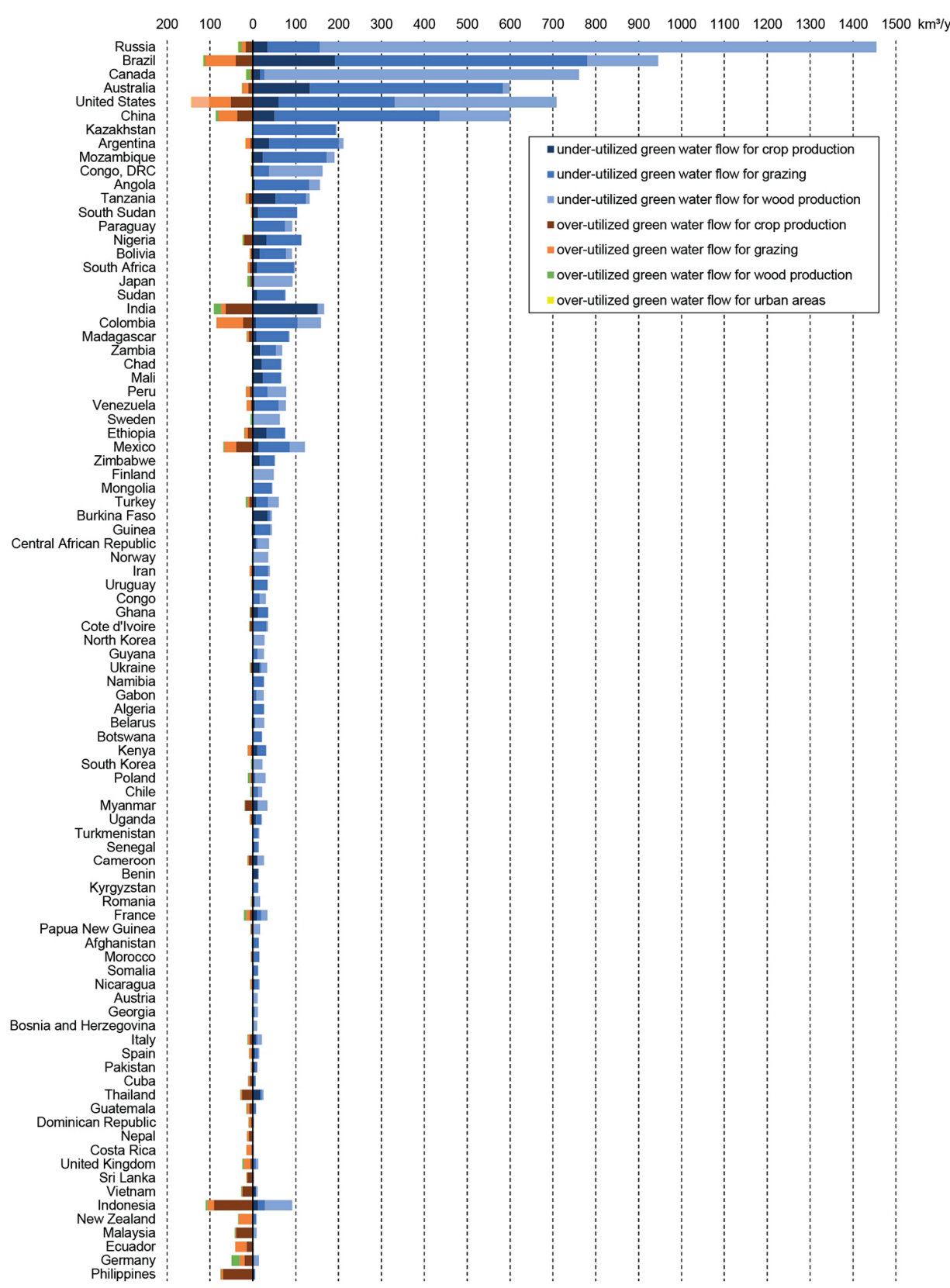

Figure D-2. Over-utilized (left hand side of y-axis) and under-utilized (right hand side of $y$-axis) green water flow broken down per purpose. Data are only shown for countries where the under- and/or over-utilized flow is $>10 \mathrm{~km}^{3} / \mathrm{y}$ and are ordered based on the difference between the under- and over-utilized flow. For Cuba and below, the overutilized flow is larger than the under-utilized flow. 


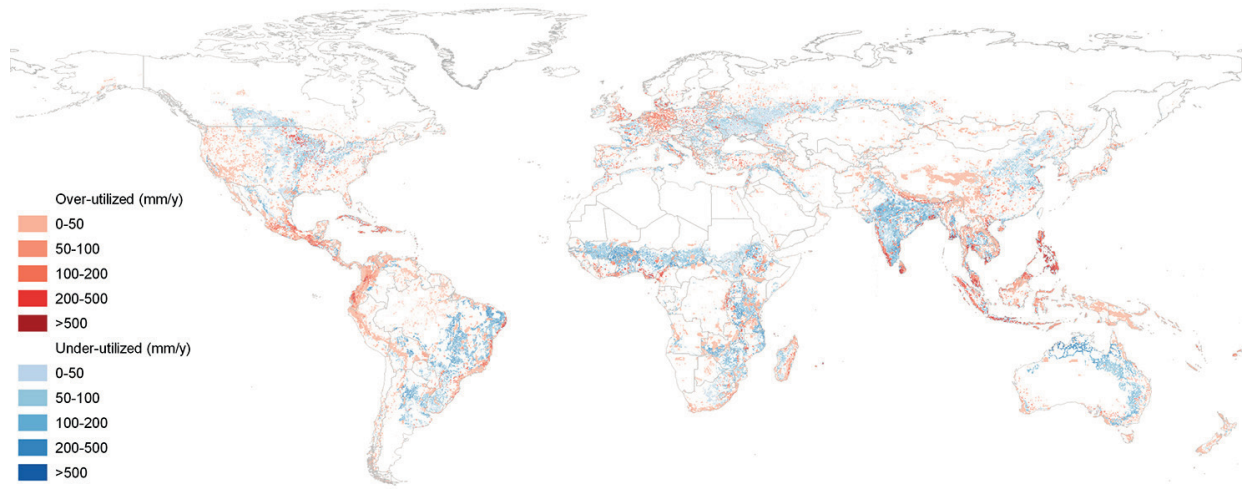

Figure D-3. Over- and under-utilization of the green water flow for crop production in $\mathrm{mm} / \mathrm{y}$ on a $5 \times 5$ arc minute grid.

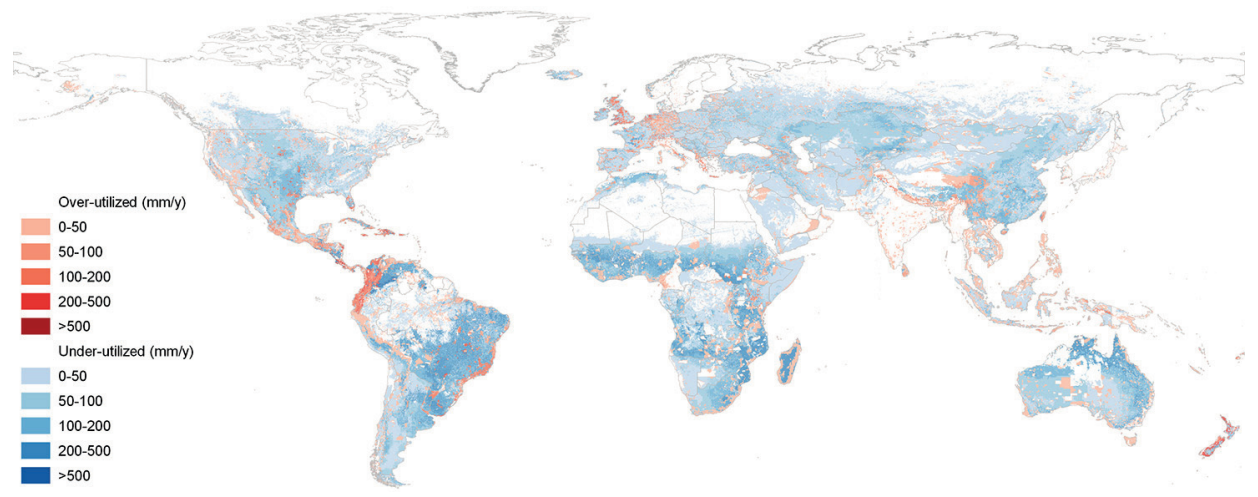

Figure D-4. Over- and under-utilization of the green water flow for livestock grazing in $\mathrm{mm} / \mathrm{y}$ on a $5 \times 5$ arc minute grid. 


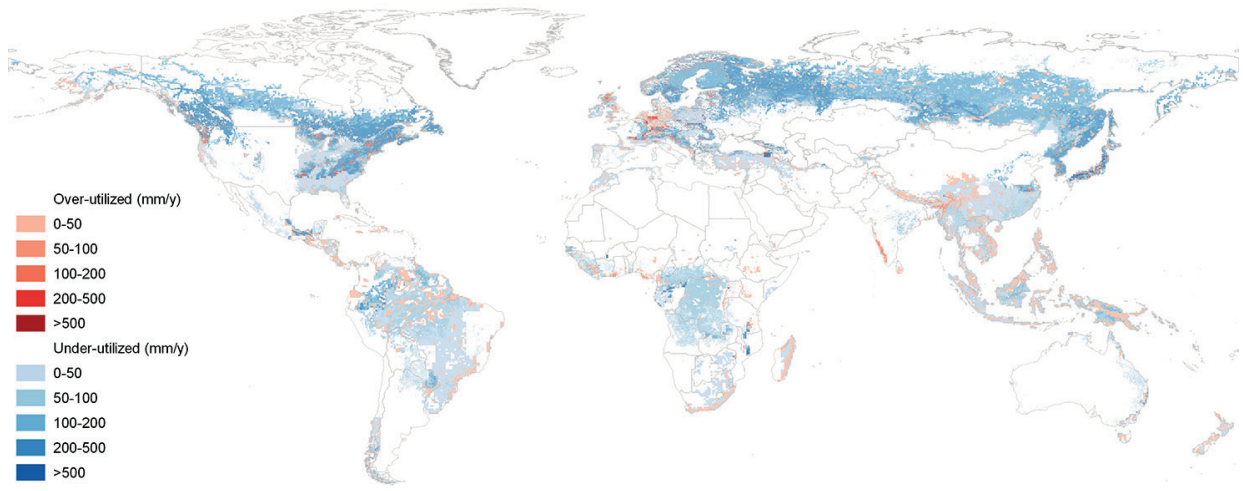

Figure D-5. Over- and under-utilization of the green water flow for wood production in $\mathrm{mm} / \mathrm{y}$ on a $5 \times 5$ arc minute grid.

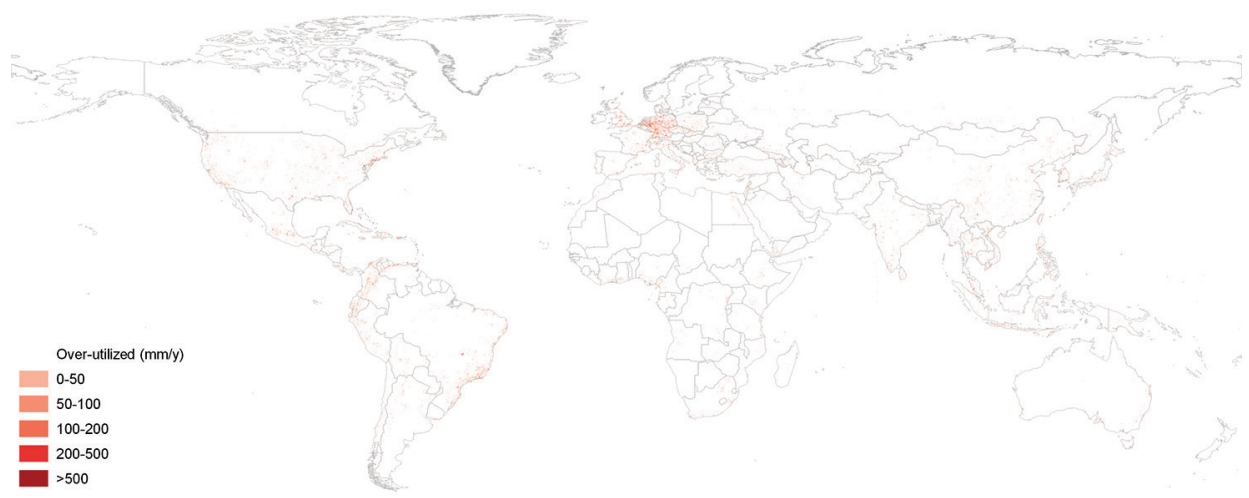

Figure D-6. Over-utilization of the green water flow for urban areas in $\mathrm{mm} / \mathrm{y}$ on a $5 \times 5$ arc minute grid. 


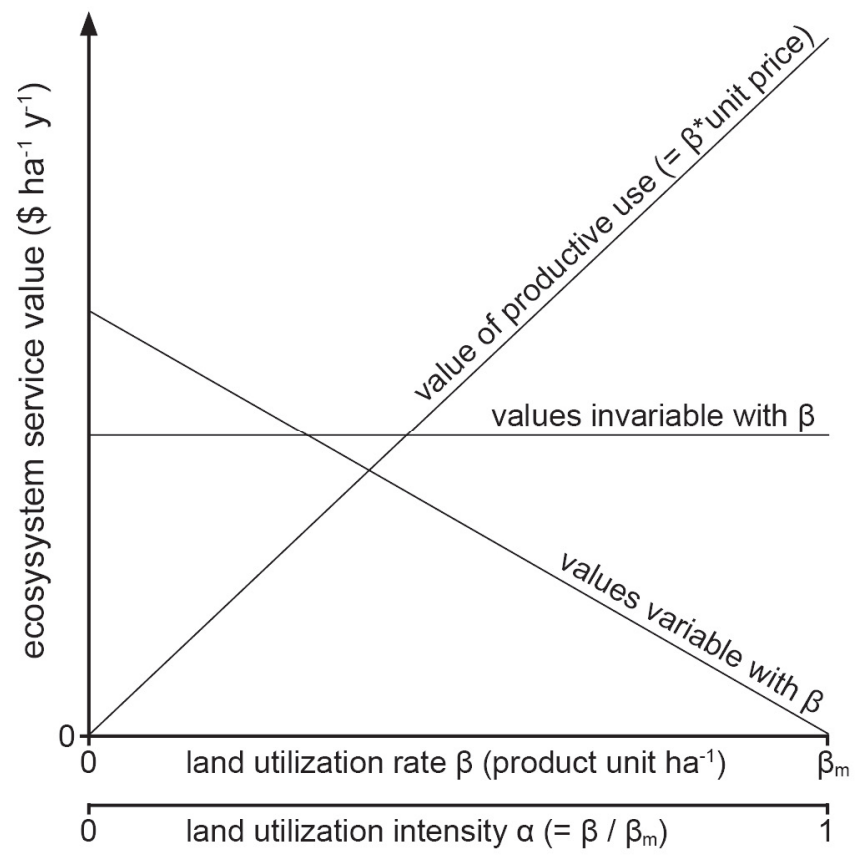

Figure D-7. Conceptual relationships (due to lack of data, assumed to be linear in this study) between the value of ecosystems services and the actual $(\beta)$ and maximum sustainable $\left(\beta_{\mathrm{m}}\right)$ land utilization rate.

\section{D.3. Discussion on the Water Footprint of Livestock Grazing}

Our global estimate of the green water footprint $\left(W F_{\mathrm{g}}\right)$ of grazing falls between previous estimates that considered the total evaporation from grazing lands and those that take only the fraction of this total that relates to the grass actually consumed (see Table D-4, Appendix D.1). Although our estimate of the total grazed grass consumed is comparable to the one by Mekonnen \& Hoekstra (2012b) $\left(2,660 \times 10^{6} \mathrm{t}\right.$ dry matter/y in our study vs. $2,768 \times 10^{6} \mathrm{t}$ dry matter/y in theirs), we estimated the WF per unit of grass grazed to be nearly three times larger $\left(857 \mathrm{~m}^{3} / \mathrm{t}\right.$ in our study vs. $297 \mathrm{~m}^{3} / \mathrm{t}$ in theirs). Mekonnen \& Hoekstra (2012b) probably underestimated the WF per unit of grass grazed, because they used an average evaporation rate per country for pasture area and assumed the pasture yield to be $80 \%$ of the yield of fodder crops. De Fraiture et al. (2007) assumed the WF per unit of grass consumed to be $750 \mathrm{~m}^{3} / \mathrm{t}$ dry matter $\left(882 \mathrm{~m}^{3} / \mathrm{t}\right)$, but seem to have estimated a much lower total grass consumption when derived backwards from their global $W F_{\mathrm{g}}$ of grazing $\left(840 \mathrm{~km}^{3} / \mathrm{y} / 750 \mathrm{~m}^{3} / \mathrm{t}\right.$ dry matter ${ }^{*} 1000=1,120 \times 10^{6} \mathrm{t}$ dry matter/y). Our estimate of total grass consumption seems to be more reasonable, since it not only compares well to Mekonnen \& Hoekstra (2012b), but to Bouwman et al. (2005) for the 
year 1995 as well $\left(2,445 \times 10^{6} \mathrm{t}\right.$ dry matter/y in our study vs. 2,400x10 $\mathrm{t}$ dry matter/y in theirs). Furthermore, our global estimate of $W F$ of grazing might be higher than the estimates by De Fraiture et al. (2007) and Mekonnen \& Hoekstra (2012b), because our estimate of the total evaporation from grazing lands $\left(12.5 \times 10^{3} \mathrm{~km}^{3} / \mathrm{y}\right.$ for 1985-1999) is on the high side of the spectrum, similar to that by Hanasaki et al. (2010). 


\section{List of Publications}

\section{Peer-Reviewed Journal Articles}

Schyns, J.F. \& Hoekstra, A.Y. (2014) The added value of water footprint assessment for national water policy: a case study for Morocco, PLoS ONE, 9(6): e99705.

Schyns, J.F., Hamaideh, A., Hoekstra, A.Y., Mekonnen, M.M., \& Schyns, M. (2015) Mitigating the risk of extreme water scarcity and dependency: the case of Jordan. Water, 7(10): 5705-5730.

Schyns, J.F., Hoekstra, A.Y. \& Booij, M.J. (2015) Review and classification of indicators of green water availability and scarcity, Hydrology and Earth System Sciences, 19(11): 4581-4608.

Schyns, J.F., Booij, M.J. \& Hoekstra, A.Y. (2017) The water footprint of wood for lumber, pulp, paper, fuel and firewood, Advances in Water Resources, 107: 490-501.

Schyns, J.F., Hoekstra, A.Y., Booij, M.J., Hogeboom, H.J., Mekonnen, M.M (submitted) Limits to the world's green water resources for food, feed, fibre, timber and bioenergy.

\section{Conference Abstracts}

Schyns, J.F., Hamaideh, A., Hoekstra, A.Y., Mekonnen, M.M., \& Schyns, M. (2015) Towards sustainable water management in a country that faces extreme water scarcity and dependency: Jordan, abstract H41G-1426, doi: 10.13140/RG.2.1.3670.8887, presented at AGU Fall Meeting 2015, San Francisco, USA, 14-18 December.

Hogeboom, H.J., Schyns, J.F., Krol, M.S., Booij, M.J. \& Hoekstra, A.Y. (2016) Modelling water footprints of crop production on an annual basis using AquaCrop: the case of wheat in China, presented at Final EURO-AGRIWAT conference, Wageningen, the Netherlands, 7-9 March.

Schyns, J.F., Booij, M.J. \& Hoekstra, A.Y. (2017) Water for Wood Products versus Nature, Food or Feed, Geophysical Research Abstracts, 19, abstract EGU2017-6891, presented at EGU General Assembly 2017, Vienna, Austria, 24-28 April.

\section{Other}

Schyns, J.F. \& Hoekstra, A.Y. (2014) The water footprint in Morocco: the added value of water footprint assessment for national water policy, Value of Water Research Report Series No. 67, UNESCO-IHE: Delft, the Netherlands.

Schyns, J.F. \& Hoekstra, A.Y. (2014) La valeur ajoutée de l'evaluation d'empreinte eau pour la politique national de l'eau: une etude de cas pour le Maroc, traduction d'un article de recherche publie en anglais dans la revue PLoS ONE, 9(6): e99705.

Schyns, J.F. (2016) Strategies for countries to mitigate the risks of extreme water scarcity and dependency in a sustainable way, discussion article on the Global Water Forum, http://www.globalwaterforum.org/2016/01/04/strategies-for-countriesto-mitigate-the-risks-of-extreme-water-scarcity-and-dependency-in-asustainable-way/?pdf=12689. 


\section{About the Author}

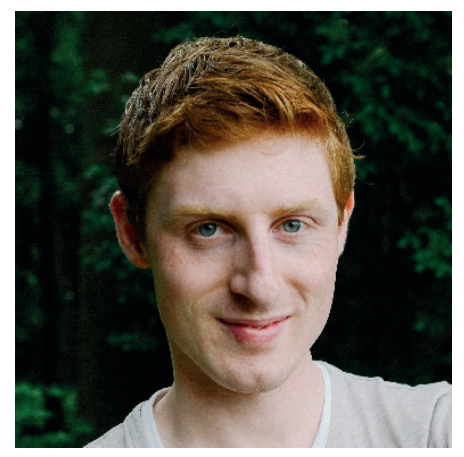

Joseph (Joep) Franciscus Schyns was born on 6 October 1989 in Doetinchem, the Netherlands, where he was raised and completed his pre-university education (VWO) at the Rietveld Lyceum in 2008 (with distinction).

Thereafter, he moved to Enschede to obtain his BSc (2011) and MSc degree (2013, with distinction) in Civil Engineering \& Management at the University of Twente. Joep's BSc project was to assess the water footprint of a large Heineken maltery, particularly looking at the water needs for barley production in the sourcing regions and placing this in the local environmental context. His MSc thesis was on the added value of Water Footprint Assessment for national water policy, which resulted in the second chapter of this dissertation. During this project, Joep paid two visits to Morocco to discuss his research at the ministries of water and agriculture. In 2014, he was awarded the prize for best thesis of the Civil Engineering \& Management master programme.

In 2013, Joep was offered the PhD position at the Water Management chair of the University of Twente that culminated in this dissertation. Since then, Joep has published in international peer-reviewed journals, presented at international conference sessions (one of which he organized himself) and participated in several expert meetings on water and the Sustainable Development Goals. Regarding education, Joep has supervised two MSc and several BSc theses, assisted during several Master courses at the department and acted as a teacher for the Water Footprint Assessment e-learning course. Furthermore, Joep has given guest lectures to high school students, PhD students and the general public. Still excited to do policy-relevant research, Joep will continue in academia for now. 



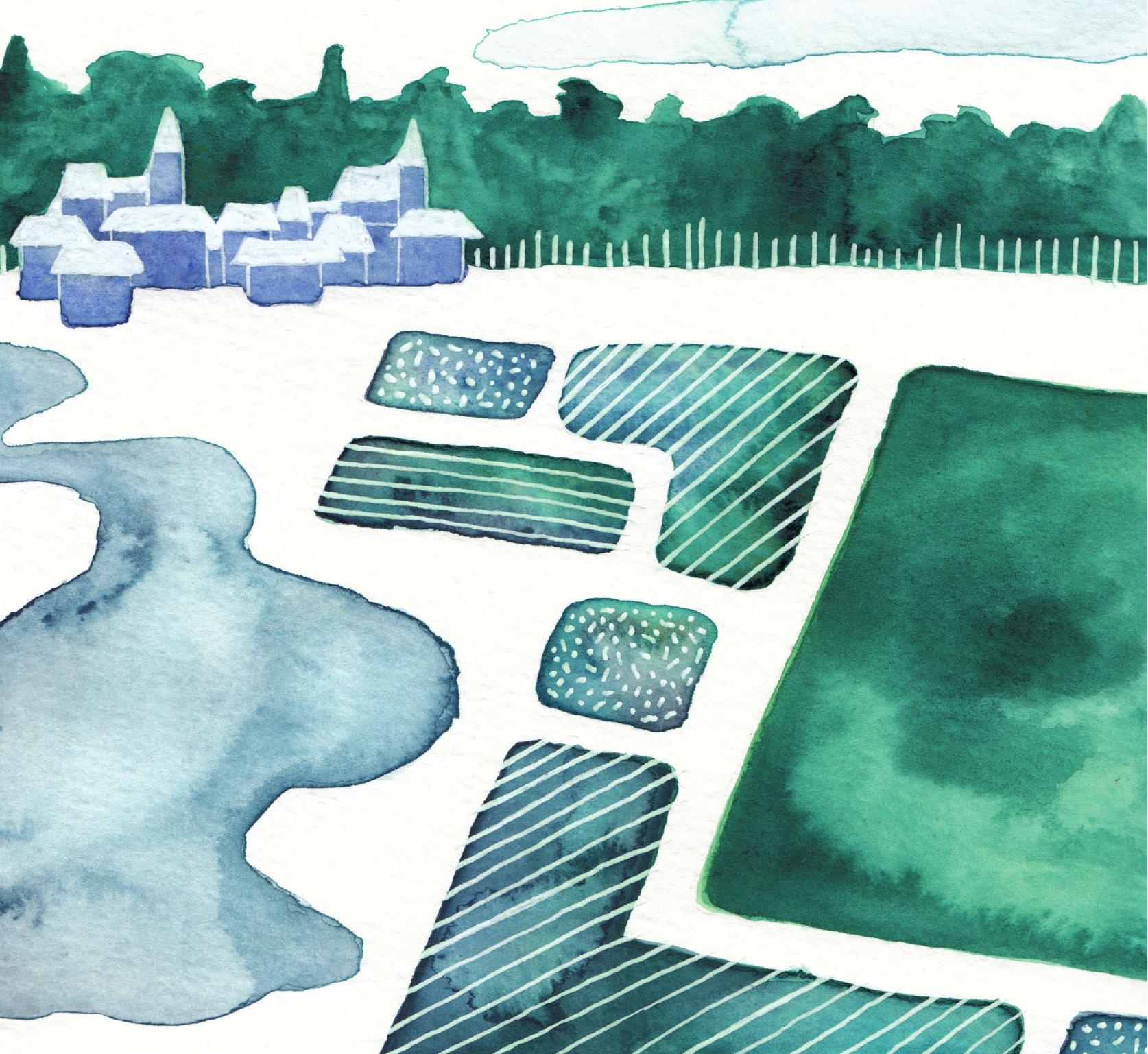

